\title{
The influence of adult education on the increase of social inclusion
}

Citation for published version (APA):

de Greef, M. (2012). The influence of adult education on the increase of social inclusion. [Doctoral Thesis, Maastricht University]. Datawyse. https://doi.org/10.26481/dis.20120912mg

Document status and date:

Published: 01/01/2012

DOI:

10.26481/dis.20120912mg

Document Version:

Publisher's PDF, also known as Version of record

\section{Please check the document version of this publication:}

- A submitted manuscript is the version of the article upon submission and before peer-review. There can be important differences between the submitted version and the official published version of record.

People interested in the research are advised to contact the author for the final version of the publication, or visit the DOI to the publisher's website.

- The final author version and the galley proof are versions of the publication after peer review.

- The final published version features the final layout of the paper including the volume, issue and page numbers.

Link to publication

\footnotetext{
General rights rights.

- You may freely distribute the URL identifying the publication in the public portal. please follow below link for the End User Agreement:

www.umlib.nl/taverne-license

Take down policy

If you believe that this document breaches copyright please contact us at:

repository@maastrichtuniversity.nl

providing details and we will investigate your claim.
}

Copyright and moral rights for the publications made accessible in the public portal are retained by the authors and/or other copyright owners and it is a condition of accessing publications that users recognise and abide by the legal requirements associated with these

- Users may download and print one copy of any publication from the public portal for the purpose of private study or research.

- You may not further distribute the material or use it for any profit-making activity or commercial gain

If the publication is distributed under the terms of Article $25 \mathrm{fa}$ of the Dutch Copyright Act, indicated by the "Taverne" license above, 


\section{The influence of adult education on the increase of social inclusion}

De invloed van volwasseneneducatie op de toename in sociale inclusie

The relation between learning environment, trainee characteristics and transfer effects 
(C) Maurice P.V.M. de Greef, 's-Hertogenbosch, The Netherlands, 2012 ISBN 9789461591647

Vormgeving omslag \& fotografie: Lydia Heringa (Identity Design - QWasp)

All rights reserved

Printed and bound by Datawyse, Maastricht, The Netherlands 


\section{The influence of adult education on the increase of social inclusion}

\section{De invloed van volwasseneneducatie op de toename in sociale inclusie}

The relation between learning environment, trainee characteristics and transfer effects

Proefschrift ter verkrijging van de graad van doctor aan de Universiteit Maastricht op gezag van rector magnificus Prof. Dr. L.L.P. Soete. Volgens het besluit van het College van Decanen in het openbaar te verdedigen op woensdag 12 september 2012 om 16.00 uur

door

Maurice Pieter Victor Michiel de Greef

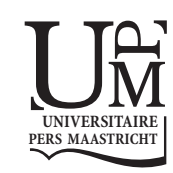




\section{Promotores}

Prof. Dr. M. Segers

Prof. Dr. D. Verté ～(Vrije Universiteit Brussel)

Beoordelingscommissie

Prof. Dr. W. Gijselaers (Voorzitter)

Prof. Dr. R. Constantinescu (University of Craiova)

Prof. Dr. J. Schols 
Dedicated to Prof. Dr. Max van der Kamp

for his inspiration

and his wonderful contribution

for this field of research 



\section{Acknowledgements}

I have finished! By completing this dissertation I have tried to contribute to the field of adult education. A field which explores the development of adult participants by analysing their learning process. A process which, in my opinion, is necessary for some of us to find a better place in daily life. Especially for vulnerable adults, the chance of reflection and innovation during learning is worth the effort to increase their self-esteem.

For me personally accomplishing this study, particularly writing this dissertation, was an enormous learning experience. An experience which I will never forget and which started in 2005 at a European conference with Prof. Dr. Dominique Verté. He tried to persuade me to start this dissertation. In 2006 and 2007 Mrs. Suzy Mommaerts tried again and she succeeded. And off we went! A journey full of surprises which included validation, analyses and writing. It was not always an easy journey (referring to several hindrances which stood in our path). After each debate, discussion and reflection we were able to drive on.

Sometimes it felt like the famous Route '66, on the long and never ending road. But now at the end of this road our trip seems to be useful with pretty good results. Satisfactory results for not only the field of adult education, but also for me. I have learned a lot, such as that quality can only exist by taking your time. Don't hurry, don't worry, be happy! But this important step in my life would never have been realised without the support of some people, whom I would very much like to thank for their support.

First of all I would like to thank Prof. Dr. Liesbeth de Donder, Dr. Simon Beausaert, Dra. Tine Buffel and Drs. Ron Jonathan Pat-El. You have all helped me at the most crucial moments to conduct the correct analysis or use the correct theoretical background. Especially you, Liesbeth, what should I have done without your enormous help? Secondly I owe a lot to ir. Andrea Kuijpers. I could depend on you, at any time, to deliver an article in the splendid English language. Thank you for all the reading, translation and your well-willingness. Thirdly I would like to thank Lydia Heringa for her marvelous work done by developing a picture by my story and realising the beautiful cover of this book.

There are two persons I wish to especially thank. Whom I admire for their patience, critical view, inspiration, their ambition for enormous quality and their way of handling my difficult questions and my ongoing pressure to finish an article or this dissertation, namely Prof. Dr. Mien Segers and Prof. Dr. Dominique Verté. Dominique and Mien I really admire your way of working. You are both professionals who pursuit extreme quality and only go for the best! If our countries had more professionals like you, our knowledge society would no longer be a challenge, but a fact! I owe you both a lot of gratitude!!

Besides the professional support of two experts and coaches, you need support from people in your direct surroundings. In my life there were some people who gave their absolute support during my learning process. They were always nearby, and without their compliments, their shoulders and their pep talk I would not have succeeded. Mum, dad, Yvonne and of course Marieke thank you for every moment you have helped me during this 
extraordinary learning process. Not one word can express my feelings of gratitude, but I will always be grateful for the support every second of the day.

But after four and half years a new road has to be paved. A road with new moments of learning, which will hopefully lead me to new ways to increase my social inclusion in this daily life. 


\section{Table of contents}

Acknowledgements

Chapter 1: Introduction: The impact of education on social inclusion among vulnerable adults: An approach for future research

Based upon De Greef, M., Verté, D. \& Segers, M. (2011). The Impact of Education on Social Inclusion Among Vulnerable Adults: An Approach for Future Research. In Despotović, M \& Popović, K., Andragogical Studies: Journal for the Study of Adult Education and Learning. Belgrade:

University of Belgrade, Faculty of Philosophy.

1. Background

2. Towards an introduction of the outcome of adult education defined as social inclusion

2.1 Activation and Internalisation

2.2 Participation and Connection

3. A perspective of adult education enhancing social inclusion: the need of transfer in a transformational approach

4. Towards a learning environment of social inclusion for vulnerable adults

4.1 Trainee characteristics

4.2 The transfer design

4.3 The participants' environment

5. Research questions

5.1 Research questions 1 and 2 (chapter 2)

5.2 Research questions 3 and 4 (chapter 3 and 4)

5.3 Research question 5 (chapter 5)

6. References

Chapter 2: Evaluation of the outcome of lifelong learning programs for social inclusion: a phenomenographic research

Published as De Greef, M., Verté, D. \& Segers, M. (2012). Evaluation of the outcome of lifelong learning programmes for social inclusion: a phenomenographic research. International Journal of Lifelong

Education. DOI: 10.1080/02601370.2012.663808.

1. Background

2. Towards a concept of social inclusion as a result of lifelong education

3. The four categories of social inclusion 
3.1 Activation

3.2 Internalisation $\quad 40$

3.3 Participation 40

3.4 Connection $\quad 40$

4. Characteristics of lifelong learning programs aiming to increase social inclusion

4.1 Trainee characteristics: the importance of self-directed learning

4.2 The training design: the relevance of a constructivistic perspective

4.3 The environment: the importance of life-circumstances

5. Research design and research questions 43

6. Methodology 44

6.1 A phenomenographic approach $\quad 44$

6.2 Sample $\quad 44$

6.3 Method of data collection: procedure 45

6.4 Data analysis: Analysis of phenomenographic transcripts 47

7. Results 48

7.1 Conception 1: Increase of mastery 49

7.2 Conception 2: Increase of the feeling of having a stronger identity

7.3 Conception 3: Increase of social mobility 51

7.4 Conception 4: Increase of and improvement in relationships 52

7.5 Influences of the learning environment 52

8. Conclusions and discussion $\quad 55$

9. References 56

\section{Chapter 3: Development of the SIT, an instrument to evaluate the} transfer effects of adult education programs for social inclusion

Published as De Greef, M., Segers, M. \& Verté, D. (2010). Development of the SIT, an instrument to evaluate the transfer effects of adult education programs for social inclusion. Studies in Educational Evaluation (36), 42 - 61.

1. Background

2. The issue of transfer in adult education programs for social inclusion

3. Towards the evaluation of adult education programs for social inclusion 
3.1 Input measures: Background characteristics, motivation and self-directed learning

3.1.1 Background characteristics and motivation of the participants

3.1.2 Self-directed learning

3.2 Process measures: Transfer design and life-circumstances

3.2.1 Transfer design: Learning contents and -activities, teacher support and transfer climate

3.2.2 Life-circumstances

3.3 Outcome measures: Social inclusion as an effect of adult education programs

3.3.1 Social inclusion as process of activation and internalisation

3.3.2 Social inclusion as process of participation and Connection

4. Methodology

4.1 Sample

4.2 Procedure

4.3 Instrument development $\quad 72$

4.3.1 Input measures

4.3.1.1 Scale 1: Background characteristics 72

4.3.1.2 Scale 2: Self-directedness in learning 72

4.3.2 Process measures 72

4.3.2.1 Scale 3: Transfer design: teacher support, learning contents and -activities, transfer climate $\quad 72$

4.3.2.2 Scale 4: Life-circumstances 73

4.3.3 Outcome measures $\quad 73$

4.3.3.1 Scale 5: Social inclusion based on activation and internalisation

4.3.3.2 Scale 6: Social inclusion based on participation and connection

4.4 Testing and refinement

4.5 Method of analysis $\quad 74$

5. Results 74

5.1 Towards an empirical based structure of the SIT-instrument $\quad 74$

5.2 Internal validity for the instrument and its process- and outcome measures

6. Conclusions and discussion $\quad 82$

7. References $\quad 84$ 
8. Appendix A: Table of clarification and justification of contents of SIT-instrument

9. Appendix B: Overview of scales and items of the SIT-instrument

\section{Chapter 4: Differential effects of adult education on adult learners'} increase in social inclusion

Based upon De Greef, M., Verté, D. \& Segers, M. (submitted). Differential effects of adult education on adult learners' increase in social inclusion.

1. Background

2. Outcome of training and education in terms of social inclusion

3. Social inclusion explained as a multidimensional process based on four pillars

3.1 Activation and internalisation

3.2 Participation and connection

4. The influence of trainee characteristics on transfer 103

4.1 Gender

4.2 Racial background

4.3 Age

105

4.4 Family status: marital status and number of kids 105

4.5 (Un)employment

106

4.6 Educational background

106

4.7 Motivational orientation

4.8 Self-directedness in learning

5. Research goals and research questions 107

6. Methodology

6.1 Sample

6.2 Procedure

6.3 Instruments

6.3.1 Social inclusion

6.3.2 Self-directedness in learning

6.3.3 Socio-economical backgrounds

6.3.4 Motivational orientation

6.4 Statistical analyses

7. Results

7.1 Descriptives

7.2 Differences between subgroups

7.2.2 Racial background 
7.2.4 Family composition

7.2.5 (Un)employment

7.2.6 Educational background

7.2.7 Motivational orientation

7.2.8 Self-directedness in learning

8. Conclusions and discussion

9. References

Chapter 5: Understanding the effects of training programs for vulnerable adults on social inclusion as part of continuing education

Published as De Greef, M., Segers, M. \& Verté, D. (2012).

Understanding the effects of training programs for vulnerable adults on social inclusion as part of continuing education. Studies in Continuing

Education. DOI: 10.1080/0158037X.2012.664126.

1. Background

2. Training programs for enhancing social inclusion

3. Trainee characteristics

4. Transfer design

4.1 Learning contents and -activities

4.2 Transfer climate

4.2.1 Transfer possibilities

4.2.2 Direct surroundings

4.3 Teacher support

4.4 Life-circumstances

5. Transfer effects in terms of increase of social inclusion

5.1 Social inclusion as process of activation and internalisation

5.2 Social inclusion as process of participation and connection

6. Research goals and research questions

7. Methodology

7.1 Sample

7.2 Procedure

7.3 Instruments

$\begin{array}{ll}7.4 \text { Statistical analyses } & 139\end{array}$

8. Results 139

8.1 Descriptives 139

8.2 Correlations 141

8.3 Logistical regression $\quad 144$

9. Conclusions and discussion 148

10.References 150 
Based upon De Greef, M., Segers, M. \& Verté, D. (2012). The Impact of lifelong learning programs on social inclusion among vulnerable adults. Lifelong Learning in Europe. Vol. XVII, Issue 1.

1. Background 156

2. Transition effects in terms of social inclusion

3. The role of adult education for increasing participants' social inclusion

3.1 Trainee characteristics

3.2 The transfer design: transfer climate, learning contents and -activities and teacher support

3.3 The participants' environment based on the life-circumstances

4. Research questions according the outcome of lifelong learning programs aiming social inclusion

5. Results

5.1 Research questions 1 and 2

5.2 Research questions 3 and 4

5.3 Research question 5

6. Implications for practice: "Transition to social inclusion by lifelong learning"

7. Suggestions for further research

8. References

About the author

1. Biography 175

2. List of publications 175

\section{Samenvatting}

1. Transfer van educatie in termen van sociale inclusie

2. De rol van de leeromgeving betreffende de bevordering van social inclusie

2.1 Deelnemerskenmerken

2.2 Transfer design: transferklimaat, leerinhoud en -activiteiten en docentondersteuning

3. Onderzoeksvragen betreffende de outcome van onderwijsprogramma's ter bevordering van sociale inclusie

4. Setting

5. Resultaten 
5.2 Onderzoeksvragen 3 en 4

5.3 Onderzoeksvraag 5

6. Implicaties voor de praktijk: Transitie naar sociale inclusie door levenslang leren

7. Suggesties voor vervolgonderzoek 189

8. Referenties 



\section{List of figures and tables}

Figure 1.1 Balance between processes of Social Inclusion

Figure 2.1 Quadrant of Social Inclusion

Figure 2.2 Checklist of Dey (1993) to prevent biases during phenomenographical study

Table 2.1 Sample characteristics: Participants' background $(\mathrm{N}=32)$

Table 2.2 Conceptions of social inclusion, described in terms of themes of the learning environment

Table 3.1 Sample characteristics: Participants' background $(\mathrm{N}=308)$

Table 3.2 Reliability of process- and outcome measures of the SIT-instrument

Table 3.3 Correlation between scales of the process- and outcome measures

Table 3.4 Correlation between the constructs of the process- and outcome measures of the SIT-instrument

Table 3.5 Factorloadings of process- and outcome measures of the SIT-instrument

Figure 4.1 Quadrant of Social Inclusion

Table 4.1 Sample characteristics: Participants' background $(\mathrm{N}=787)$

Table 4.2 Questionnaires used in this study, scales, example items per scale and reliability coefficients $(\mathrm{N}=308)$

Table 4.3 Fit indices and correlations factors SIT-model

Table 4.4A Means and standard deviation of change in social inclusion variables for increase of social inclusion

Table 4.4B Means and standard deviation of change in social inclusion variables for stabilisation or decrease of social inclusion

Table 4.5A Percentages of increase in social inclusion variables based on sociodemographic factors by crosstabs

Table 4.5B Percentages of increase in social inclusion variables based on educational background, motivation and self-directedness in learning by crosstabs

Table 4.6A Results of bivariate analyses between sociodemograhic factors and social inclusion variables among participants who experience an increase of social inclusion

Table 4.6B Results of bivariate analyses between educational background, motivation and self-directedness in learning and social inclusion variables among participants who experience an increase of social inclusion

Table 5.1 Respondents' background characteristics ( $\mathrm{N}=787$ )

Table 5.2 Questionnaires used in this study, scales, example items per scale and reliability coefficients $(\mathrm{N}=308)$

Table 5.3 Fit indices and correlations factors SIT-model

Table 5.4A Means and standard deviation of change in social inclusion variables for increase of social inclusion 
Table 5.4B Means and standard deviation of change in social inclusion variables for stabilisation or decrease of social inclusion

Table 5.5 Spearman's Rho after crosstabs between training design characteristics and social inclusion variables among participants who experience an increase of social inclusion

Table 5.6A Logistic regression results with social inclusion variables of Activation \& Internalisation as dependent variables

Table 5.6B Logistic regression results with social inclusion variables of Participation \& Connection as dependent variables

Table 6.1 Conceptions of social inclusion, described in terms of themes of the learning environment

Table 6.2 Means and standard deviation change in social inclusion variables for increase of social inclusion

Table 6.3A Logistic regression results with social inclusion variables of Activation \& Internalisation as dependent variables

Table 6.3B Logistic regression results with social inclusion variables of Participation \& Connection as dependent variables 


\title{
Chapter 1: Introduction: The impact of education on social inclusion among vulnerable adults: An approach for future research
}

\author{
Based upon De Greef, M., Verté, D. \& Segers, M. (2011). The Impact of Education on Social \\ Inclusion Among Vulnerable Adults: An Approach for Future Research. In Despotović, M \& \\ Popović, K., Andragogical Studies: Journal for the Study of Adult Education and Learning. \\ Belgrade: University of Belgrade, Faculty of Philosophy.
}

\begin{abstract}
According to the Alliance for Health \& The Future (2005) the group of vulnerable adults is growing. Taking the ongoing development of the knowledge society, the individualisation and globalisation into account this group of vulnerable adults risks social exclusion. According to Schedler (1998) and Christian (1974) (adult) education can prevent social exclusion and enable vulnerable adults to cope with problems in daily life. More research is needed in order to understand more clearly how adult education programs can enhance the increase of social inclusion among vulnerable adults. Firstly in order to explore learners' perceptions, a phenomenographical research could provide insights in the meaning of learning outcome in terms of social inclusion. Secondly, regarding the lack of evidence-based research on learning outcome of adult education development of an instrument in measuring the outcome of adult education is needed. It can be expected that social inclusion among vulnerable adults will increase after joining education and that the learning environment (based on the transfer of training model) will influence this increase. In short this article will provide a research agenda (based on deskresearch and literature study) concerning the outcome of adult education in terms of increasing social inclusion among vulnerable adults.
\end{abstract}




\section{Background}

Present day society can be defined as an ongoing risk society (Schedler, 1998) increasingly leading to social exclusion among vulnerable adults. According to Schedler (1998) ongoing developments like globalisation, individualisation and privatisation makes it more and more difficult for vulnerable adults to join (activities and life) in society. Moreover the group of vulnerable adults is growing. Still 22 per cent of the population in the industrialised countries is illiterated (UNICEF, 2008). Besides this according to The Alliance for Health \& The Future (2005) an estimated 35 per cent of the European population will be over the age of 60 in 2050 instead of the 20 per cent at present. Regarding to these two figures one can say that European society is confronted with an increasing number of vulnerable people who risk social exclusion.

Meanwhile Europe is also changing into a knowledge society. In this perspective one of the most important means of production is knowledge, produced by "human capital" on the labour market.

Next to participating in the labour market, individuals should be able to cope with the growing responsibility of making life decisions in our complex individualised society. As to our present day risk society, there is a lack of competencies for vulnerable people in their ability to make their own decisions, for example in contacting official organisations or in managing their own finances. Consequently they risk social exclusion.

Schedler (1998) argues that education can prevent ongoing threat of social exclusion. In this context Levitas et al. (2007, p.25) defines the process of social exclusion as "a lack or denial of resources, rights, goods and services and the ability to participate in normal relationships and activities".

Education can prevent social exclusion in society (Christian, 1974). In this context the Mannheim Research Institute for the Economics of Aging (2008) states that low educated people (regarding their lower social-economical status) run a bigger risk in having poor mental health or depression. Likewise the OECD confirms that learning has to be seen as one of the basic needed services in society enhancing social inclusion among its inhabitants (Christian, 1974). According to Christian (1974) the OECD prefers to facilitate learning to stimulate possibilities of individual development to cope with daily life.

In this respect, the European Commission (2000) ensures possibilities for adult education by the Treaty of Lisbon. In order to ensure social inclusion among vulnerable adults the Life Long Learning Program in Europe provides educational programs and projects. At any rate the additional value of educational programs for vulnerable adults can be formulated as a guidance in "human actions" to increase understanding, decision making, participation, literacy and numeracy (Crittenden, 1968) as well as an increase of self-confidence. Due to the ongoing modernisation of technology it is essential that vulnerable people can increase their competencies through education in order to cope with new social demands in our knowledge society. These vulnerable adults need for example to learn how to cope with social problems in daily life using internet or a cell phone, to manage their financial 
administration or becoming a member of a new association. Moreover they have to learn to use the opportunities available to them in order to fully participate in nowadays society (Department of Work and Pensions, 2008).

Considering education as an effective intervention to increase social inclusion, regular schooling systems do not counter for vulnerable adults. Given prior negative school experiences among most of them different approaches in learning are necessary. According to Jarvis and Griffin (2003) one has to develop a learning process to enhance the quality of life instead of only focussing on employment as the principal goal of adult education. More concrete according to McClusky (1970) and Serrano-García and Bond (1994) a main goal is to support vulnerable adults in pursuing a decrease of marginalisation and an increase in empowerment to survive in modern European society. Instead of cognitive gains and employment, the outcome of adult education for vulnerable people can be seen as an increase in social inclusion (Main, 1979; Solarczyk-Ambrozik, 1998). In order to gain a better life standard vulnerable participants learn to cope with problems in daily life. As a result they endeavour a kind of empowerment (Serrano-García and Bond, 1994).

A crucial question for adult education programs is: how to organise adult education in order to optimise its effects in term of enhancing social inclusion of its participants?

In this article, we answer this question in three steps. Firstly, we elaborate on the construct of social inclusion. Secondly, we present an overview of literature on the elements of the learning environment that can enhance the outcomes of adult education ${ }^{1}$ in terms of social inclusion. Thirdly, we elaborate on the guidelines for further research, which is needed to give more insights in features and outcomes of adult education aiming to increase social inclusion.

\section{Towards an understanding of the outcome of adult education defined as social inclusion}

In order to describe social inclusion as an outcome of adult education, two perspectives have to be taken into account.

First of all, interactionism explains the importance of the individual in its (learning ) environment. Because of the interaction between the individual and the changing environment, behaviour can be changed (Bandura, 2001, 2004, 2006; Endler and Magnusson, 1976; Krueger et al., 2008). In this context on the one hand the environment can be a determining factor in behavioural change (Nye and Hargreaves, 2009). On the other hand, the individual is capable of making his or her own choices and determines his or her own future plans, driven by "the self" (Markus and Nurius, 1986). Likewise the identity

\footnotetext{
${ }^{1}$ In this manuscript the terms adult education, lifelong learning and continuing education are interchangeable and refer to the same contents. All three terms refer to the learning-programs for adults concerning basic education aiming increase of social inclusion.
} 
process theory (as a possible interpretation of interactionism) states that behavioural change can be possible if a balance between maintaining consistency of the self and changing it in response to experiences can be found (Krauss Whitbourne, 2005). Therefore to change ones behaviour in a productive way in order to increase social inclusion the environment as well as "the self" can play a crucial role.

Secondly Carstensen $(1995,1998,2006)$ developed the socioemotional selectivity theory to explain social interactions among people (Santrock, 2008). Due to the process of ageing accordingly to Carstensen $(1995,1998,2006)$, elderly focus more on the emotional rewards of social interactions than on gaining knowledge (possibly seen as functional rewards).

Accordingly vulnerable people can join adult education programs aiming to increase contacts with others to cope with loneliness (emotional perspective) or, for example to increase their knowledge about using the Internet (functional perspective). In this context social inclusion can be seen as encountering functional problems (like reading letters) and social problems (like contacting neighbours) in daily life.

Figure 1 shows how the theoretical perspectives of interactionism and socioemotional selectivity can be combined. In view of the aforementioned perspectives on social inclusion, four processes of social inclusion can be distinguished, namely: (a) activation, (b) internalisation, (c) participation and (d) connection. In this context, activation and participation can be seen as processes to increase functional knowledge, skills and attitude to encounter problems in daily life. An example of activation is organising and reading the post (on an individual level) and of participation is visiting the doctor (in contact with the environment). On the contrary, internalisation and connection are processes describing the increase of emotional rewards with, on the one hand being more assertive (on an individual level) and on the other hand gaining more personal contacts (in contact with the environment).

Figure 1: Balance between processes of Social Inclusion

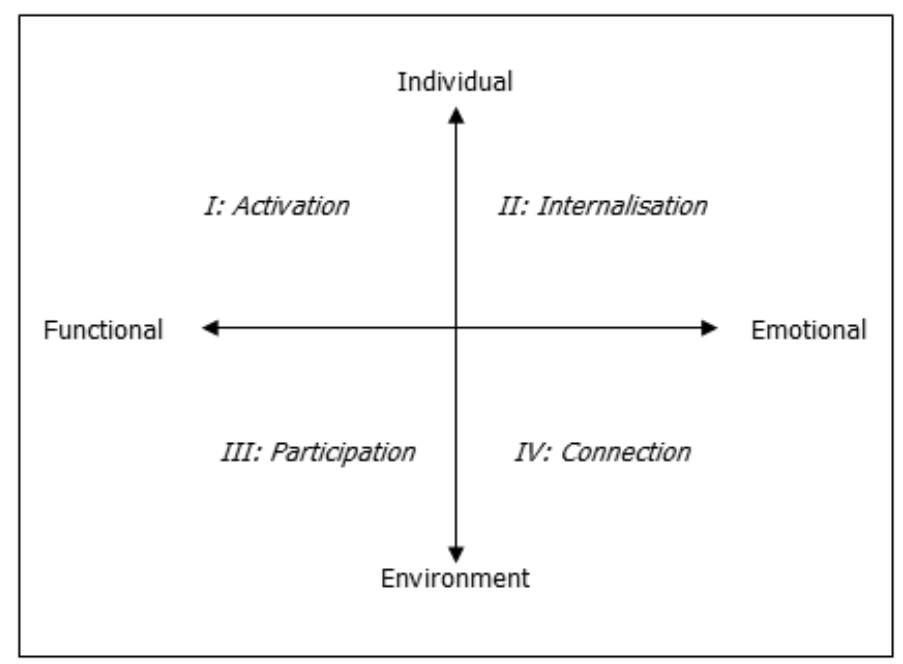




\subsection{Activation and Internalisation}

According to Fortuin and Keune (1997) social inclusion is a process aiming to activate people. Movisie (2010) defines activation as a process of enhancing the ability to function in daily life. Whenever people are activated they are able to manage daily problems in life in order to survive. As for example writing a letter to the housing company or communicating in different languages abroad. Furthermore Ben-Zur and Michael (2007) argue that in order to be active in daily life, different coping strategies have to be internalised.

Secondly internalisation can be defined as a process of feeling happier and safer as well as feeling of being able to cope with problems in daily life. Likewise Mastergeorge (2001) states that internalisation is a process of gaining a higher level of satisfaction and the ability to manage one's own life. In order to be satisfied, personal development and self-regulation of behaviour is needed. Behaviour such as making the right decisions or being assertive when needed, can support the development of an own personality or identity. In this context assertiveness and decision making are seen as behaviour concerning internalisation. As a result of internalisation vulnerable adults are able to feel more satisfied with themselves and are able to manage their own lives (Mastergeorge, 2001) and therefore feel more accepted in society (Guildford, 2000).

\subsection{Participation and Connection}

Buffel et al. (2007) state that education can lead to an increase of social inclusion in terms of participation (Guildford, 2000). Accordingly participation can be defined as taking part in society or in a cultural setting (Buffel et al., 2007). In this respect the study of Verté et al. (2007) indicates that people participate by taking the opportunity to go out in the evening or visit activities in the community.

Besides being more active and participating more in society and or feeling better and more satisfied in life, connection between vulnerable adults can increase. In this context connection means gaining new or improving existing social interactions or relationships and meeting others (Colley, 1975; Smith, 2007; Huisman et al., 2003; Priemus, 2005; Verté et al., 2007). Consequently establishing relationships can lead to a decrease of loneliness (De Jong-Gierveld, 1987). Likewise Antonucci and Akiyama (2002), Antonucci, Lansford and Akiyama (2001) and Antonucci, Vandewater and Lansford (2000) state that this "social support" can ensure that vulnerable people cope more effectively in daily life. 


\section{A perspective of adult education enhancing social inclusion: the need of transfer in a transformational approach}

Research of adult education during the last four decades has provided us with a wide diversity of perspectives and insights into educational processes. In order to provide understanding of the possible influence of adult education on the increase of social inclusion, one of the most interesting theories is based on the andragogical perspective of transformational learning. Transformational learning is a learning process in which the learner experiences events in daily life, reflects on them and tries to improve them by using new knowledge, skills or a changed attitude (Mezirow, 1991). This learning is defined as a transformational process. Likewise Daloz (2003) states that education is a transformational journey. More specifically life is seen as a journey in which we learn by looking back on past experiences and consequently transforming the meaning of it (Daloz, 2003). Hence learning can be seen as on ongoing process of transforming life experiences. In fact (behavioural) change occurs not automatically, but is only possible by reflection on (life )events (resulting in transformation) (Lynch and Field, 2007). Likewise Crittenden (1968) defines education as a guide for human action to increase self-confidence, participation, decision making and understanding. In other words, throughout an educational process, the adult learner tries to change his or her behaviour in order to improve his or her competencies for coping in daily life.

According to theories concerning transformational learning, they give insights in the way in which education aiming increase of social inclusion is organised. However in this field of adult education little research of empirical validation has been done. On the contrary, the field of Human Resource Development (HRD) compiled several studies in order to gain insights in the outcome of training (as an example of adult education) (Holton, Chen and Naquin, 2003; Alvarez, Salas and Garafano, 2004; Burke and Hutchins, 2007; Cheng and Hampson, 2008; Aguinis and Kraiger, 2009). According to most of these studies, the training programs have low to moderate transfer of training effects (e.g.Baldwin and Ford, 1988). In the perspective of adult education aiming to increase social inclusion, transfer can be seen as the implementation of learned knowledge, skills and attitude to encounter problems in daily life. According to Baldwin and Ford (1988) and many authors in this field building upon this study (Thijssen, 2001; Cheng and Ho, 2001; Holton, Chen and Naquin, 2003; Nijman, 2004; Nijhuis, Segers and Gijselaers, 2005; Cheng and Hampson, 2008) the trainee him- or herself, the training program and the environment in which transfer takes place, are the most important groups of variables influencing behavioural change.

\section{Towards a learning environment of social inclusion for vulnerable adults}

Based on HRD-studies we can discern three groups of variables: (1) trainee characteristics,

(2) transfer design and (3) the participants' environment. To date most HRD-studies 
(addressing the effect of training programs) try to reveal an explanation for enhancement of transfer of training in terms of enhancing job performance, professional development of the trainees and organisational payoffs (for recent review studies, see Aguinis and Kraiger, 2009; Alvarez, Salas and Garafano, 2004; Burke and Hutchins, 2007; Cheng and Hampson, 2008; Holton, Chen and Naquin, 2003). Contrary to these studies the concept of transfer of adult learning concerning vulnerable adults aims to increase social inclusion instead of improvement of professional development or a better job performance. In this context some adaptations to the transfer-of-training-model as described in many HRD-studies have to be made.

Regarding the first variable of the transfer-of-training-model, namely trainee characteristics, one important remark has to be made. Due to the fact that adult education aims to increase social inclusion among vulnerable adults, the targetgroup is low skilled learners (instead of more high skilled learners as the targetgroup in most research of the HRD-studies).

Consequently the ability for self-direction in learning has to be part of the variable trainee characteristics. According to research of Raemdonck (2006) self-direction in learning can be a significant influencing factor for learning outcome among low skilled learners. At any rate results of her compiled study argues that self-directed learning is a relevant input variable during the learning process, which is missing in most HRD-studies.

The variable transfer design differs according to learning process aiming increase of social inclusion. Firstly the context of the transfer design (seen as part of the transfer design) differs in programs enhancing increase of social inclusion compared to job-related programs. Whenever the increase of social inclusion has to be pursued, interaction of trainees during the learning process is important as well as the use of authentic learning materials, in order to combine theory and practice. In this context constructivist learning theories are relevant (Baldwin and Ford, 1988; Van Lakerveld, Van den Berg, De Brabander et al., 2000; Tenenbaum et al., 2001; Thijssen, 2001; Holton, Chen and Naquin, 2003; Simons and Bolhuis, 2004; Nijhuis, Segers and Gijselaers, 2005; Van der Vlerk, 2005;). Secondly whereas in job-related programs the supervisor plays a crucial role in organising possibilities for transfer (Nijman, 2004), in the programs for social inclusion the teacher fullfills this role. Third and lastly the learning environment is not the same as the group of variables, labelled as "general work environment" in many HRD-studies. In programs for social inclusion, it should be seen as the environment of the daily life of the participant based on his or her lifecircumstances, as for example health, feelings of safety and happiness (Andrews and Withey, 1974).

\subsection{Trainee characteristics}

The group of vulnerable adults participating in adult education programs is very heterogeneous. This raises the question of (in)equality of adult education. To what extent do all groups of participants have equal chances to reach the expected learning gains in terms 
of increase in social inclusion? Different subgroups can be based on age, educational background, gender, family composition, (un)employment, racial background and motivation. The relevance of these characteristics of the participants is evidenced by prior research on social inclusion.

Firstly social inclusion research of Verté et al. (2007), age, gender, number of children, marital status, level of schooling, prior diplomas and courses, (un)employment, motivation and racial background are determining characteristics in blocking or stimulating social inclusion (after learning). More specifically Verté et al. (2007) defined the needs and pathways of social inclusion among 70.000 elderly in Flanders in relation to housing, mobility, spare time, unsafety, care and participation in culture. According to his results, the needs of elderly and their social inclusion are influenced by aforementioned sociodemographic characteristics. If these background variables determine the rate and features of social inclusion, they have an influence on the effects of adult education on social inclusion.

Besides the background characteristics described by Verté et al. (2007), studies of selfdirectedness in learning as (Knowles 1975; McGivney, 1992; Raemdonck, 2006; Ryan and Deci, 2000) state the importance of self-directed learning. Specifically Raemdonck et al. (2008) defines self-directed learning as "a tendency to take an active and self-starting approach to learning activities and situations and to persist in overcoming barriers and setbacks to learning". The research done by Raemdonck (2006) addressed the role of selfdirected learning for low skilled employees. The results of her research indicate that selfdirectness in learning benefits the learning outcome of low skilled learners (Raemdonck, 2006). In this perspective Raemdonck (2006) indicates the importance of self-directness among the targetgroup vulnerable adults by giving insights in the fact that the level of selfdirectness in learning will be influenced for reaching better learning outcomes by low qualified people.

\subsection{The transfer design}

The transfer design of the adult education programs refers to three factors: (1) the teacher support, (2) transfer climate and (3) the learning contents and -activities.

First, concerning teacher support, Brinkerhoff and Montesino (1995) as well as Cromwell and Kolb (2004) state that the support of a trainer or teacher has a positive correlation with the outcome of transfer. For example the teacher gives advice in applying a learned attitude in daily life, or how to implement a plan for improving attitude in daily practice. Hence the role of a teacher can be significant for the increase of transfer (Hutchins and Burke, 2006). In this respect as a second factor Nijman (2004) refers to transfer climate and transfer possibilities as variables in the environment of the learner influencing the transfer of a course: the opportunity to use new knowledge, skills and attitudes on the job, the 
sanctioning of transfer by others, resistance to change in the environment, both the positive and negative personal outcomes of transfer and peer support.

Thirdly the learning process is an interactive process which helps to acquire and further develop knowledge, skills and attitudes by experiencing new activities and contents. Tenenbaum et al. (2001) argue it should be a constructivistic process based on seven different aspects, namely: (1) arguments, discussions, debates among learners (2) conceptual conflicts and dilemmas, (3) sharing ideas with others, (4) the use of materials and measures targeted toward solutions, (5) enhancing learners' reflections and concept investigation, (6) meeting the learners' learning needs and (7) making meaning by addressing real life examples during the instructional unit. These seven aspects of the learning process are relevant for designing adult education programs aiming to increase social inclusion.

\subsection{Life-circumstances}

Research on the transfer of training has shown the relevance of the work environment of trainees to improve the transfer effects of training. However, in adult education programs aiming to enhance social inclusion, it can be argued that not the work environment but the daily life-circumstances influence transfer of learning and increase social inclusion, namely spare time, housing, care and finances (Caplan and Barton, 1978; Liu, 1974; Andrews and Withey, 1974). For example if one has to raise children, occupy a paid job or has to take care of a relative or friend, time for transfer is limited. Besides these life-circumstances mentioned by Andrews and Withey (1974), barriers in mobility or feeling too old can block transfer (McGivney, 1992).

\section{Research questions}

Different authors have stressed the need of gaining insight in the outcome of adult education programs in terms of increase of social inclusion in order to improve its quality (Partridge, 1999; Nilsson, 2010) investigation among vulnerable adults is required. In order to provide insight in learning outcomes and the variables influencing five research questions are adressed.

\subsection{Research questions 1 and 2 (chapter 2)}

The construct social inclusion is complex and often refrerred to as a multidimensional concept. Therefore two first relevant questions are: 
1. How do adults understand the impact of participating in adult education programs on their feelings of social inclusion?

2. What are the educationally critical aspects that differentiate between qualitatively varying ways of experiencing learning adult education?

Given a phenomenon will be investigated, the phenomenographical approach has been chosen as method (Tan, 2008). According to Tan (2008) experiences (and its interpretations and meaning for the learners) of a complex phenomenon can be explored by this research approach. This question qill be addressed in chapter 2 .

\subsection{Research questions 3 and 4 (chapter 3 and 4)}

To date, hardly any evidence is reported on the effects of adult education in terms of social inclusion and on the variables that might influence these effects. Moreover, no instruments are available to measure these effects and their influencing variables. Therefore, the first step is to develop and validate an instrument which measures social inclusion as an outcome of adult education and the influencing variables (chapter 3 ).

More specifically, given the aforementioned influencing individual variables, the instrument has to measure the rate of increase of social inclusion after joining adult education programs for social inclusion for the different subgroups of participants. The second step is collecting evidence on the extent to which adult education programs realise an increase of social inclusion (chapter 4). Moreover given the heterogeneity of the participating groups, the question is if there are differential affects acoording to the subgroups. This leads to two research questions:

3. What is the specific outcome of adult education programs in terms of social inclusion of vulnerable adults?

4. What are the differences between subgroups of participants with respect to increase in social inclusion (in terms of activation, internalisation, participation and connection) after joining programs of adult education?

\subsection{Research question 5 (chapter 5)}

Adult educators face a major challenge when designing programs for vulnerable adults, with the core goal to increase their level of social inclusion. Although there is a lot of research on how to design training programs to enhance transfer effects, most of it is conducted in the context of job-related programs. The programs which are central in our studies, have a different aim as well as targetgroup. This raises the question to what extent training design variables, argued upon in transfer of training research, are valid in the context of adult 
education for vulnerable adults aiming to improve social inclusion. Therefore in chapter 5 , we address the question:

5. What is the relationship between learning environment (seen as combination of lifecircumstances and transfer design) and increase of social inclusion among vulnerable adults?

Chapter 6 summarises and discusses the results of the different studies. This dissertation contains four studies that are presented in chapters two to five. Those studies have either been published in international peer reviewed journals or accepted for publication or have been submitted. Therefore, some parts of information may appear repeatedly in the different chapters.

\section{References}

Aguinis, H., \& Kraiger, K. (2009). Benefits of training and development for individuals and teams, organizations, and society. Annual Review of Psychology, 60, 451 - 474.

Alvarez, K., Salas, E., \& Garofano, C.M. (2004). An integrated model of training evaluation and effectiveness. Human Resource Development Review, 3 (4), 385 - 416.

Andrews, F. M. \& Withey, S. B. (1974). Developing measures of perceived life quality: Results from several national surveys. Social Indicators Research, 1974 (1), 26.

Antonucci, T. C. \& Akiyama, H. (2002). Aging and close relationships over the life span. International Society for the Study of Behavioural Development Newsletter (1, Serial No. 41), 2 - 5.

Antonucci, T. C. Lansford, J. E. \& Akiyama, H. (2001). The impact of positive and negative aspects of marital relationships and friendships on the well-being of older adults. In J. P. Reinhardt (Ed.), Negative and positive support. Mahwah, NJ: Erlbaum.

Antonucci, T. C., Vandewater E. A. \& Lansford, J. E. (2000). Adulthood and aging: Social processes and development. In A. Kazdin (Ed.), Encyclopedia of Psychology. Washington, DC \& New York: American Psychological Association and Oxford University Press.

Baldwin, T. T. \& Ford, K. J. (1988). Transfer of training: A review and directions for future research. Personnel Psychology, 1988 (41), 43.

Bandura, A. (2001). Social cognitive theory. Annual Review of Psychology, (52). In J. W. Santrock (2008), Life-span development. New York: McGraw-Hill, 46 - 47.

Bandura, A. (2004). Toward a psychology of human agency. Paper presented at the meeting of the American Psychological Society, Chicago. In J. W. Santrock (2008), Life-span development. New York: McGraw-Hill, 46 - 47.

Bandura, A. (2006). Going global with socio cognitive theory: From prospect to paydirt. In S. I. Donaldson, D. E. Berger \& K. Pezdek (Eds.), The rise of applied psychology: New frontiers ad rewarding careers. 
Mahwah, NJ: Erlbaum. In J. W. Santrock (2008), Life-span development. New York: McGraw-Hill, 46 $-47$.

Ben-Zur, H. \& Michael, K. (2007). Men's affective reactions life events: the roles of coping strategies and personal outcomes. The Journal of Men's Health \& Gender, Vol. 4 (3), 358.

Brinkerhoff, Robert O., and Max U. Montesino (Fall 1995). Partnerships for transfer of training: Lessons from a corporate study. Human Resource Development Quarterly, 6 (3), 263 - 274.

Buffel, T., Van Wing, T., Verhaest, W. \& Verté, D. (2007). Making meaning of socio-cultural adult education. In M. S. Giannakaki, The teacher and the teaching profession: Current Research and International Issues. Athens: ATINER, 389 - 403.

Burke, L. A. \& Hutchins H. M. (2007). Training transfer: An integrative literature review. Human Resource Development Review 6 (3), 263 - 296.

Caplan, N. and Barton, E. (1978). The potential of social indicators: Minimum conditions for impact at the national level as suggested by a study for impact at the national level as suggested by a study of the use of "Social Indicators" 73. Social Indicators Research, 5(4), 427 - 456.

Carstensen, L. L. (1995). Evidence for a life-span theory of socioemotional selectivity. Current Directions in Psychological Science, 4, 151 - 156. In J. W. Santrock (2008), Life-span development. New York: McGraw-Hill, 651 - 652.

Carstensen, L. L. (1998). A life-span approach to social motivation. In J. Heckhausen \& C. Dweck (Eds.), Motivation and self-regulation across the life-span. New York: Cambridge University Press. In J. W. Santrock (2008), Life-span development. New York: McGraw-Hill, 651 - 652.

Carstensen, L. L. (2006). The influence of a sense of time on human development. Science, 312, $1913-$ 1915. In J. W. Santrock (2008), Life-span development. New York: McGraw-Hill, 651 - 652.

Cheng, E. W. L. \& Hampson, I. (2008). Transfer of training: A review and new insights. International Journal of Management Reviews 10 (4), 15.

Cheng, E. W. L. \& Ho, D. C. K. (2001). A review of transfer of training studies in the past decade. Personnel Review, $30(1), 17$.

Christian, D. E. (1974). International Social Indicators: The OECD Experience. Social Indicators Research 1 (2), 169.

Colley, D. G. (1975). A social change index - an objective means to discern and measure the relative current social condition of cities, towns, and their sub-communities. Social Indicators Research, 1975 (1), 26.

Crittenden, B. S. (1968). What is educational value? Journal of Value Inquiry, 2 (4), 235.

Cromwell, S. and Kolb, J. (2004). An examination of work environment support factors affecting transfer of supervisory skills training to the work place". Human Resource Development Quarterly, 15 (4), 449 471.

Daloz, L. A. (2003). Education as a transformational journey. In: P. Jarvis \& P. Griffin (2003). Adult and Continuing Education: Major themes in education. London: Routledge, 105 - 125.

De Jong-Gierveld, J. (1987). Developing and testing a model of loneliness. Journal of Personality and Social Psychology, 5, 119 - 128.

Department of Work and Pensions (2008). Working Together: UK National Action Plan on Social Inclusion. London: Department for Work and Pensions. 
Endler, N., S. \& Magnusson, D. (1976). Toward an interactional psychology of personality. Psychological Bulletin, 83, 956 - 974.

European Commission (2000). A Memorandum on Lifelong Learning. 4-8-2010. <http://www.bolognaberlin2003.de/pdf/MemorandumEng.pdf>.

Fortuin, K. \& Keune, C. (1997). Anders praten over jeugd: Naar een begrippenkader voor preventief jeugdbeleid. Utrecht: Verwey-Jonker Instituut.

Guildford, J. (2000). Making the case for social and economic inclusion. Canada Atlantic Region: Population and Public Health Branch.

Holton, E. F., Chen H. \& Naquin, S. S. (2003). An examination of learning transfer system characteristics across organizational settings. Human Resource Development Quarterly, vol. 14 (4), 24.

Huisman, J., Pijls, T., Van Hoeij, J., Van Voorst van Beest, K., Boonaerts, Y. \& Lens, M. (2003). Portfolio sociale competenties: Primair onderwijs, vmbo, mbo. 's-Hertogenbosch: CINOP.

Hutchins, H. M. \& Burke, L. A. (2006). Has relapse prevention received a fair shake? A review and implications for future transfer research. Human Resource Development Review, 5 (1), 8 - 25.

Jarvis, P. \& Griffin, P. (2003). Adult and Continuing Education: Major themes in education. London: Routledge.

Knowles, M. S. (1975). Self-directed learning: A guide for learners and teachers. New York: Association Press.

Krauss Whitbourne, S. (2005). Adult development \& aging: Biopsychological perspectives. Hoboken: John Wiley \& Sons, Inc.

Krueger, R. F., South, S., Johnson, W. Iacono, W. (2008). The heritability of personality is not always $50 \%$ : Gene-environment interactions and correlations between personality and parenting. Journal of Personality, 76, 1485 - 1522.

Levitas, R., Pantazis, C., Fahmy, E., Gordon, D., Lloyd, E. \& Patsios, D. (2007). The Multidimensional analysis of social exclusion. London: Department for Communities and Local Government.

Liu, B. (1974). Quality of life indicators: a preliminary investigation. Social Indicators Research, 1974 (1), 22, 187 - 208.

Lynch, H. \& Field, J. (2007). Getting stuck, becoming unstuck - transitions and blockages between learning contexts. Paper presented at the Annual Conference of the British Educational Research Association (BERA). Stirling: University of Stirling.

Main, M. (1979). Social and personality-development. Contemporary Psychology, 24 (8), 11.

Mannheim Research Institute for the Economics of Aging. (2008). SHARE: Survey of Health, Ageing and Retirement in Europe. Mannheim: Mannheim Research Institute for the Economics of Aging.

Markus, H. \& Nurius, P. (1986). Possible selves. American Psychologist, 41, 954 - 969. In S. Krauss Whitbourne (2005), Adult development \& aging: Biopsychological perspectives. Hoboken: John Wiley \& Sons, Inc., 259.

Mastergeorge, A. M. (2001). Guided Participation in sociocultural learning: Intervention and apprenticeship. Academic Search Premier, 22 (1), 14.

McClusky, H., Y. (1970). A dynamic approach to participation in community development. Journal of Community Development Society, 1970, 1, 8. 
McGivney, V. (1992). Tracking adult learning routes: A pilot investigation into adult learners'starting points and progression to further education and training. Leicester: National Institute of Adult Continuing Education.

Mezirow, J. (1991). Fostering Critical Reflection In Adulthood. San Francisco - Oxford: Jossey-Bass Publishers.

Nijhuis, J. F. H., Segers, M. S. R. \& Gijselaers, W. H. (2005). Influence of redesigning a learning environment on student perceptions and learning strategies. Learning Environments Research, 2005 (8), 27.

Nijman, D.J.J.M. (2004). Supporting Transfer of Training: Effects of the Supervisor. Enschede: Universiteit Twente.

Nilsson, A. (2010). Vocational education and training - an engine for economic growth and a vehicle for social inclusion. International Journal of Training and Development, 14, 4, 251-272.

Nye M. \& Hargreaves, T. (2009). Exploring the Social Dynamics of Proenvironmental Behavior Change: A Comparative Study of Intervention Processes at Home and Work. Journal of Industrial Ecology, vol. $14(1), 137$.

Partridge, M. (1999). Monitoring Adult Education: Monitoring adult education for knowledge-based policymaking. Hamburg: Druckerei Seemann.

Priemus, H. (2005). Het spel en de knikkers: Fysieke en sociale pijler verbonden. Tijdschrift B\&G / Uitgave Bank Nederlandse Gemeenten en Vereniging van Nederlandse Gemeenten, 2005 (1), 5.

Raemdonck, I. (2006). Self-directedness in learning and career processes: A study in lower-qualified employees in Flanders. Gent: Universiteit van Gent.

Raemdonck, I., De Grip, A., Segers, M. Thijssen, J. \& Valcke, M. (2008). Zelfsturing in leren en loopbaan als predictoren van employability bij laaggeschoolde werknemers. Gedrag en organisatie (21), 4.

Ryan, R. M. \& Deci E. L. (2000). Self-determination theory and the facilitation of intrinsic motivation, social development, and well-being. American Psychologist, vol. 55 (1), 11.

Santrock, J. W. (2008). Life-span development. New York: McGraw-Hill.

Schedler, A. (1998). How Should We Study Democratic Consolidation? Democratization, 5 (4), 1 - 19.

Serrano-García, I. \& Bond, M. A. (1994). Empowering the silent ranks: Introduction. American Journal of Community Psychology, 22 (4), 13.

Simons, R-J. S. \& Bolhuis, S. (2004). Constructivist learning theories and complex learning environments. In Mulder, R.H. \& Sloane, P.F.E., New approaches to vocational education in Europe. The construction of complex learning-teaching arrangements. Oxford: Symposium Books; and in Oxford Studies in Comparative Education, 13(1), 13 - 25.

Smith, M. K. (2007). Social capital. The encyclopedia of informal education, 2007. 26 - 07 - 2007. $<w w w . i n f e d . o r g /$ biblio/social_capital.htm>.

Solarczyk-Ambrozik, E. (19). Socio-economic transformation and adult learning in Poland. In Bisovsky, G., Bourgeois, E., Bron, M., Chivers, G. \& Larsson, S., Adult learning and social participation. Wien: Verband Wiener Volksbildung, 373 - 385.

Tan, K.H.K. (2008). Qualitatively different ways of experiencing student self-assessment. Higher Education Research \& Development, vol. 27 (1), $15-29$. 
Tenenbaum, G., Naidu, S., Jegede, O. \& Austin, J. (2001). Constructivist pedagogy in conventional on campus and distance learning practice: An exploratory investigation. Learning and construction 11, 25.

The Alliance for Health \& The Future. (2005). An ageing population: The European facts and figures. 13-082010. <http://www.thematuremarket.com/SeniorStrategic/ageing_population_european_facts-62045.html>.

Thijssen, J. (2001). Personele flexibiliteit in strategisch perspectief: De betekenis van employability voor organisatie en individu. In R. Poell \& J. Kessels, Human Resource Development, Organiseren van het leren. Alphen aan den Rijn: Samsom, 103 - 116.

UNICEF. (2008). The state of the world's children. New York: UNICEF.

Van der Vlerk, D. (2005). Inspireren tot leren: Het ontwerpen van een uitdagende leeromgeving. Bussum: Uitgeverij Coutinho.

Van Lakerveld, J., Van den Berg, J., De Brabander, C., \& Kessels, J. (2000). The corporate curriculum: a working-learning environment. In Proc. Annual Academy of Human Resource Development Conference: Expanding the Horizons of Human Resource Development. Raleigh-Durham NC.

Verté, D., De Witte, N. \& De Donder, L. (2007). Schaakmat of aan zet? Monitor voor lokaal ouderenbeleid in Vlaanderen. Brugge: Uitgeverij Van den Broele. 



\title{
Chapter 2: Evaluation of the outcome of lifelong learning programs for social inclusion: a phenomenographic research
}

\author{
Published as De Greef, M., Verté, D. \& Segers, M. (2012). Evaluation of the outcome of \\ lifelong learning programmes for social inclusion: a phenomenographic research. \\ International Journal of Lifelong Education. DOI: 10.1080/02601370.2012.663808.
}

\section{Abstract}

Our current knowledge society does not only have an impact on labour market demands, but its citizens also have to cope with increasing social demands (The World Bank, 2007). A growing number of vulnerable adults lack basic competences and therefore risk social exclusion. In this respect, The European Commission (2007) as well as the OECD agree that adult education can play a significant role in increasing social inclusion of vulnerable adults. However, to date evidence of outcome of adult education programs in terms of social inclusion is hardly available. The present study aims to unravel the complexity of the phenomenon of adult education to enhance participants' social inclusion. Using a phenomenographic approach, we have explored different experiences of 32 vulnerable adults who have participated in adult education courses. The results show that an increase on an individual level (activation and internalisation) is more often perceived by the interviewees than an increase on the collective level of social inclusion (participation and connection). To ensure successful results and to improve quality of the lifelong learning process it seems that particularly the variables teacher support, lifecircumstances and learning contents and -activities are important elements to enhance the transfer aiming to increase social inclusion. 


\section{Background}

Present-day Europe has to cope with a growing number of vulnerable adults without job perspectives (Nickell, Nunziata and Ochel, 2005). At the start of 2008 the unemployment rate in Europe was less than 7\% compared with 10\% in 2010 (Allen en Kiiver, 2011). Eighty million employees in Europe are low skilled (European Commission, 2007, 2008) and literacy problems are still "a significant share of the European population" (European Commission, 2008). This is problematic in our current knowledge society where human capital is the most important asset and the need for high skilled employees is increasing.

In addition to labour market demands, citizens have to cope with the social demands of the knowledge society (The World Bank, 2007). According to the World Bank (2007), people need to have basic competencies and lifelong learning opportunities not only to ensure job and income but also for participation in social and community networks and activities. Basic competencies are necessary in order to participate in the spheres of wealth, social and political activity (Sparkes, 1999). Examples of basic competencies are: (digital) literacy, numeracy, contacting official organisations, making decisions, choosing needed care and managing finances. Among vulnerable adults such as seniors, unemployed, people with disabilities, homeless, single parent families and immigrants (The World Bank, 2007) a growing percentage lack these basic competencies and therefore are risking social exclusion. The European Commission (2007) formulated six key measures to promote social inclusion. As Nilsson (2010) argues, these measures are in part defensive, such as the promotion of adequate social protection schemes. Proactive policies to counteract social exclusion refer to the role of education in general and adult education (or lifelong learning) more specifically. Likewise the OECD (Christian, 1974) claimed that in order to prevent social exclusion of vulnerable adults (lifelong) learning is one of the basic needed services in society to increase social inclusion. By participating in educational programs they are able to enhance their socio-economic standard of daily life.

The group vulnerable adults is a targetgroup with specific features. Most of them have negative experiences with regular educational systems. Adult education programs which approach learning and instruction in similar ways are therefore not optimal for this group. Moreover, the learning outcomes of many adult education programs are formulated in terms of qualifying for the labour market instead of supporting participants to overcome social problems in daily life. On the contrary, the participants need assistance in dealing with daily life issues, for example in joining conversations at work or at home, writing a letter to the community centre, being able to go out, using internet or a cell phone, managing their financial administration or being able to become a member of an association.

To date, evidence of the outcome of adult education programs aiming to enhance social inclusion is hardly available. Nonetheless, on the Fifth International Conference on Adult Education in Hamburg in 1997, agreement was reached on the necessity of a framework for evaluation to gain insight in the outcome and possibilities for the improvement of adult education programs (Partridge, 1999). Partridge (1999) claims that evidence is needed to 
discern the essential elements of the learning environment such as to improve the effects of the learning process in terms of enhancement of social inclusion. To date this evidence is still largely missing. This is partly due to the complexity of the phenomenon. Taking the heterogeneity of the targetgroup of vulnerable adults into account, a variety of outcomes in terms of social inclusion can be expected as well as different beliefs on how adult education programs can contribute to the result of these programs. In order to unravel the complexity of the phenomenon of adult education on social inclusion, it is valuable to explore the different experiences of the vulnerable participants themselves who join courses aiming to increase social inclusion. The meaning of social inclusion as well as the elements of adult education programs that foster the increase of social inclusion is not fixed, but is socially constructed by and between, teachers, participants and or other members of the community based on their own experiences. That is the reason why our study adopts a phenomenographic approach. This is a well-developed methodology in the field of education, which explores the qualitative different ways of understanding a complex phenomenon (Tan, 2008; Wright, Murray and Geale, 2007). Our study seeks to explore, using the methodology of phenomenography, the qualitatively different conceptions of social inclusion and of adult education to enhance social inclusion that exist among participants.

\section{Towards a concept of social inclusion as a result of lifelong education}

Different conceptualisations of social inclusion can be discerned. According to The World Bank (2007) social inclusion can be seen as "a process which ensures that those at risk of poverty and social exclusion gain the opportunities and resources necessary to participate fully in economic, social and cultural life and to enjoy a standard of living and well-being that is considered normal in the society in which they live". Likewise Van Houten (2008) states that social inclusion is the ultimate participation of every citizen in his or her own way in all facets of society. Van Regenmortel (2009) referred to it as self-control. In this respect, Levitas et al. (2007) argues that social exclusion is a multidimensional disadvantage in terms of a lack of resources and of quality of life. Scharf, Phillipson and Smith (2005) describe the multidimensionality of social inclusion in terms of a lack of resources, participation, selfcontrol and quality of life which concerns exclusion from material resources, social relations, civic activities, basic services and neighbourhood exclusion. More specifically Ogg (2005) explores direct indicators of social exclusion from the European Social Survey concerning the regularity of meeting with friends and relatives, taking part in social activities, self-rated physical health and mental health, self-rated income and the quality of the local area.

Based on the aforementioned descriptions of the concept of social inclusion, we define social inclusion as:

- a multidimensional process of individuals who

- try to control and to cope with resources and services, 
- take part in society and its activities,

- connect to social relations and

- feel included in the (local) area.

\section{The four categories of social inclusion}

The aforementioned definition indicates that social inclusion is a multidimensional process of behavioural change depending on a persons' interaction with different situations and with different environmental conditions (Endler and Magnusson, 1976; Krueger et al., 2008; Nye and Hargreaves, 2009). Specifically, it is a multidimensional process of the individual in contact with the environment resulting in emotional and functional satisfaction by taking part in society and activities, controlling and coping with resources and services, connecting to social relations and feeling included in the (local) area. This implies that social inclusion can be defined as a process of two balances.

Firstly social exclusion is a process of the individual versus the environment. From a socialpsychological perspective and more precisely the identity theories, social exclusion may be understood in terms of identity. Individuals may experience social exclusion in terms of its consequence on their personal identity. Sullivan (2002) describes social exclusion based on three identity theories: the theory of Possible Selves, The Identity Process Theory and the Social Identity Paradigm. The theory of Possible Selves (Markus and Nurius, 1986) explains the connection between present self, motivation, behaviour and possible or future self. Markus and Nurius (1986) argue that current behaviour is motivated not only by current, but also by future views of the self, which they have termed "possible selves". For vulnerable adults this means that they are motivated by their dreams and hopes of who they may become or who they hope to be. This possible self exerts a powerful influence on current behaviour. Based on this theory, social inclusion can be defined as the development of possible selves. The Identity Process theory (Breakwell, 1986, 1988) creates a concept of identity concerning an interaction between four identity processes (to be mentioned: selfesteem, self-efficacy, distinctiveness and continuity) in order to maintain the most positive self-view. If events prohibit an optimum level of these four principles a coping strategy will be sought, to overcome the threatening of the identity. Within this perspective, social inclusion means finding a way of functioning in daily life where optimum level of the four principles of identity can be reached. Finally according to Hogg and Abrams (1988) the social identity paradigm can be interpreted to understand the concept of social exclusion. Likewise Kramer et al. (2001) explains that an individual's behaviour in during collective actions relies on its identification with the group and its members. This is comparable with the social cognitive theory of Bandura, which explains that human behaviour is determined by the reciprocal interactions that occur among specific behavioural, cognitive and environmental factors (Bandura, 2001, 2004, 2006a; Santrock, 2008). For the phenomenon of social 
inclusion, this implies that the social environment of the learner can be seen as a learning forum; learning occurs within social relationships (Renshaw, 2003). According to Bandura (2006b) social change (for example increase of social inclusion) can be realised by "social" or "symbolic modelling".

Secondly an increase of social inclusion can result in emotional or functional satisfaction. Vulnerable adults can pursue an increase of social inclusion in a functional perspective (for example increase in knowledge in coping financial administration) or in an emotional perspective (for example increase in contacts with people in the local area declining feelings of loneliness). Carstensen $(1995,1998,2006)$ states that especially older people select their social interactions, focussing more on the emotional rewards of social interactions than on gaining knowledge (possibly seen as functional rewards). This tendency is described in the socio-emotional selectivity theory (Santrock, 2008).

In sum, increase in social inclusion of vulnerable adults can be defined as an interactive process aiming functional or emotional effect for the individual itself or in contact with its environment. The combination of the two balances result in a quadrant of social inclusion with four pillars (see figure 1). The first pillar describes an increase of social inclusion as a functional outcome for the individual him- or herself. On the other hand, the second pillar shows the emotional outcome for the individual. Finally, the third and fourth pillars describe the functional respectively the emotional outcome for the individual in connection with his or her environment. These four pillars can be defined as: activation (pillar one), internalisation (pillar two), participation (pillar three) and connection (pillar four).

Figure 1: Quadrant of Social Inclusion

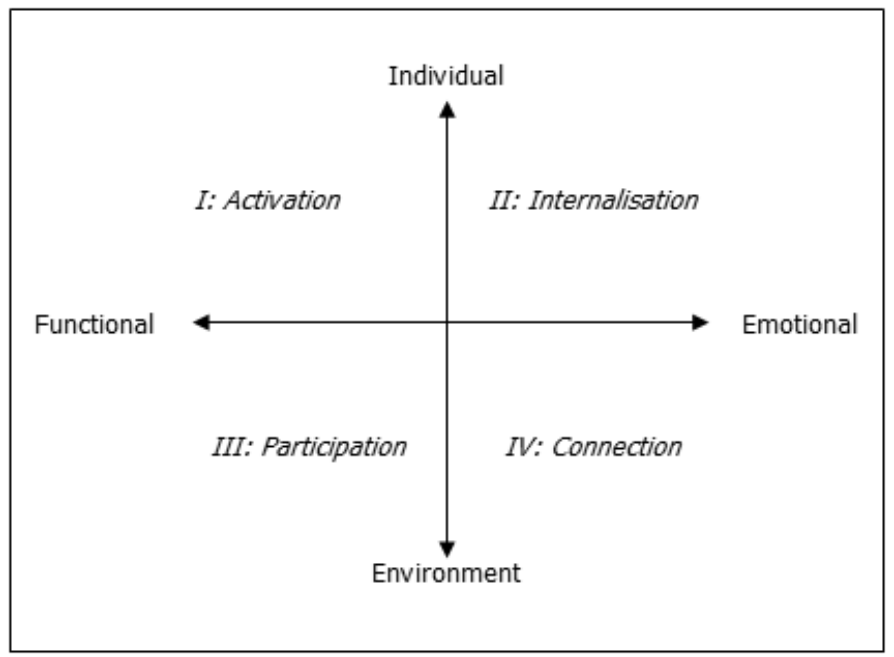




\subsection{Activation}

Increase of social inclusion in terms of activation refers to the functional outcome for the individual, that is an increase of basic skills to cope with practical daily problems, such as organising one's own finances and being informed by media (radio, internet and TV). Increase of activation leads to an increase of liveability within the direct surroundings (Fortuin and Keune, 1997). Accordingly to Ben-Zur and Michael (2007) this process is also called mastery. Krauss Whitbourne (2005) and Fortuin and Keune (1997) refer to an increase of self-control which, according to Santrock (2008) leads to an increase in the stability of self-esteem.

\subsection{Internalisation}

The second pillar regarding the increase of social inclusion is the increase of emotional satisfaction for the individual him- or herself, seen as the increase of feelings of happiness and safety. In fact this refers to a process of being satisfied with oneself and being able to lead one's own life in a responsible and happy way (Mastergeorge, 2001). Concrete example is the growing ability to make one's own choices and feeling safe in and around the house.

\subsection{Participation}

Increasing participation refers to a growing functionality of an individual in connection with his or her environment. In this respect, increase of social inclusion can be seen as doing more things in the direct surroundings (Guildford, 2000). Examples of participation are: taking part in official organisations, going out in the evenings and weekends or visiting activities in the community (Verté et al., 2007). In accordance with Krauss Whitbourne (2005) the vulnerable adult "actively participates in his or her development through reciprocal relations with the environment". In other words if vulnerable people join more social activities in the environment and are more active in doing activities which they did not undertake before, they participate more in society.

\subsection{Connection}

Emotional satisfaction of vulnerable adults in relation to their environment can be explained as having more or better contact with others. This is regarded as the increase of connection (Colley, 1975; Smith, 2007; Huisman et al., 2003; Priemus, 2005). Although independence and freedom are needed, individuals also pursue intimacy and commitment with others (Santrock, 2008). In this regard social inclusion is seen as a process of meeting others or developing new social interactions (Verté et al., 2007). Furthermore Brennan, Clark and 
Shaver (1998) point out that attachment of adults involves the degree to which individuals open up to others, being intimate and feel (in)secure in relying on them or even decline increasing loneliness (De Jong-Gierveld, 1987). Accordingly Antonucci and Akiyama (2002), Antonucci, Lansford and Akiyama (2001) and Antonucci, Vandewater and Lansford (2000) confirm that social support by personal networks of individuals can be of help in coping with daily problems in a more effective way.

\section{Characteristics of lifelong learning programs aiming to increase social inclusion}

During the last two decades outcomes of training programs for adults have mainly been addressed within Human Resource Development research. More precisely, studies have concentrated on the factors which influence the extent to which trainees apply knowledge, skills and attitudes they have acquired during the training program in their daily job. This is called the transfer effect of training (for recent review studies see Holton, Chen and Naquin, 2003; Alvarez, Salas and Garafano, 2004; Burke and Hutchins, 2007; Cheng and Hampson, 2008; Aguinis and Kraiger, 2009). Transfer of training studies (Baldwin and Ford, 1988; Cheng and Ho, 2001; Thijssen, 2001; Holton, Chen and Naquin, 2003; Nijman, 2004; Nijhuis, Segers and Gijselaers, 2005; Cheng and Hampson, 2008) essentially discern three categories of variables influencing transfer of training: the trainee him- or herself, the training program and the environment in which transfer of training takes place. Referring to these three categories Nijman (2004) described the trainee characteristics as a combination of personality characteristics and motivation, the training program (or design) as a combination of transfer design, transfer climate and supervisor support and the environment as the general work environment. The outcomes of the training programs are defined in terms of an increase in job-related skills and cognitive gains.

Adult education training programs for vulnerable adults differ from these job-related training programs in a few aspects. Firstly, the outcome of adult education of vulnerable adults is defined in terms of an increase in social inclusion (McClusky, 1970; Main, 1979; SerranoGarcía and Bond, 1994; Solarczyk-Ambrozik, 1998). Secondly, with respect to the variables influencing transfer of training, a few differences with job-related training programs can be discerned.

\subsection{Trainee characteristics: the importance of self-directed learning}

Research on the transfer of training traditionally has focussed on trainee characteristics such as self-efficacy, motivation and the extent to which trainees set their achievement goals (Pham, 2010). Well-known authors (Knowles, 1975; McGivney, 1992; Ryan and Deci, 2000) in the field of andragogy have argued on the role of self-directedness for enhancing learning 
of adults. Based on extensive literature review, Raemdonck (2006) describes selfdirectedness as primarily controlling and actively shaping one's learning process and involving self-initiated, deliberate and sustained pursuit of learning activities with the goal of enhancing and increasing one's capacity to cope for oneself. Moreover, it is characterised as a dynamic process, referring to an individual's ongoing function to constantly adapt to the environment, expressed in behaviour and regulated by cognitive (beliefs), affective (attitudes), volitional (intentions) and earlier behavioural patterns.

The relevance of self-directedness in learning in the context of adult education of vulnerable adults has been validated by Raemdonck's research (2006). Raemdonck (2006) revealed in her research among low skilled employees that the high qualified group showed significantly more self-directedness in learning than the low qualified workers group. Based on earlier findings of research in work contexts, it might be questioned as to what extent selfdirectedness plays a role in adult education programs for vulnerable adults aiming to foster social inclusion.

\subsection{The training design: the relevance of a constructivistic perspective}

In comparison with many job-related training programs, adult education programs for social inclusion have been applying to a wider extent instructional approaches that are in line with constructivist learning theories (Steele, 2005). These learning theories argue for the beneficial effect on learning when using learning materials reflecting multidimensional perspectives on a theme, or phenomenon using authentic learning materials for combining theory and practice and the importance of learner interaction (Baldwin and Ford, 1988; Van Lakerveld, Van den Berg, De Brabander et al., 2000; Holton, Chen and Naquin, 2003; Simons and Bolhuis, 2004; Nijhuis, Segers and Gijselaers, 2005; Van der Vlerk, 2005; Tenenbaum et al. 2001; Thijssen, 2001). To be more precise, Tenenbaum et al. (2001) described the basic ideas of constructivistic learning theories in seven components as a learner driven approach based on interaction and reflection by using daily life examples to solve learner's problems. It is clear that within this constructivist perspective on learning and instruction the teacher plays a crucial role in enhancing trainees' learning (Campbell and Cheek, 1989). Moreover, various studies showed a positive correlation between teacher support and transfer of training effects (Brinkerhoff and Montesino, 1995; Cromwell and Kolb, 2004; Hutchins and Burke, 2006). With respect to supporting trainees in applying what they have learned during the course to their daily life, the teacher plays an important role in, for example helping to make plans and advising in using the learned contents within their personal life and praising students when they succeed in realising transfer of training effects. 
Many studies in the field of HRD (e.g. Pham, Segers and Gijselaers, 2010) have been evidencing that transfer of training is only realised when the environment of the trainee is supportive. Many adult education programs do not aim to prepare participants for a job, but are aimed at enhancing the participants' social inclusion. Therefore, it might be questioned as to what extent the daily life environment of the participants influence the transfer of what they have learned during the program. More specifically, personal life-circumstances refer to different life-domains as family-life, health, housing and financial affairs (including technical development), economical status, cognitive satisfaction, psycho-social structures, affective happiness and a sense of belonging to society (Andrews and Withey, 1974; Liu, 1974).

Examples of life-circumstances are satisfaction in life, dealing with challenges at work, taking care of a relative or friend and encountering problems in the upbringing of children (Andrews and Withey, 1974), but also barriers, such as mobility problems or feeling old (McGivney, 1992). These life-circumstances might impede or enhance the increase of social inclusion among vulnerable adults (Andrews and Withey, 1974) and therefore might jeopardise the effects of adult education on the increase of social inclusion of the participants.

In sum the learning environment of lifelong education programs aiming social inclusion invites adults to join a constructive learning process in which transfer of learning into daily practice seems to be a significant share of the goal setting. According to the aforementioned principles of the constructivist perspective like using real life examples, interaction during learning and the importance of transfer, these programs can be seen as constructivist learning programs of lifelong education in order to increase one's social inclusion.

\section{Research design and research questions}

In this perspective, the purpose of the present study was to explore ways of understanding the social inclusion effects that take place in adult education programs. In addition, the aim was to discern the aspects that are educationally critical and to expand the understanding of impact in a more complex and complete direction. The following specific research questions were set:

1. How do adults understand the impact of participating in adult education programs on their feelings of social inclusion?

2. What are the educationally critical aspects that differentiate between qualitatively varying ways of experiencing learning adult education?

Our hypothesis was that adults' conceptions of the impact of adult education on social inclusion would display similarities to the conceptions identified in earlier studies on the transfer effects of training, but that the context of adult education programs which are not job-related but aim to increase participants' social inclusion, might give rise to unique aspects. Due to the paucity of previous research on educationally critical aspects in the 
context of adult education for social inclusion, it was not possible to form hypotheses about what these might be.

\section{Methodology}

\subsection{A phenomenographic approach}

According to Tan (2008), Levitas et al. (2007), Asworth and Lucas (2000) and Howitt and Cramer (2008) phenomenographic research is a preferred method, when a researcher aims to explore interpretations and experiences of meaning and practises of individuals concerning a complex phenomenon. Marton and Booth (1997) point out that by using phenomenography it is possible to reveal different ways of experiencing a phenomenon among participants. This method is based on a clinical interview in order to probe participants' perceptions of a phenomenon (Marton et al., 1997). In comparison with earlier studies the phenomenographic approach seems to contribute to valuable knowledge by the wider research community (Harris, 2011). Regarding the two research questions of this study, the researchers wish to explore the experiences with educational programs of adults who risk social exclusion. This results in an analysis of the experienced outcome on the one hand and the possible influence of education and its environment on the other. In other words an analysis of the phenomenon on the impact of joining adult education on the participants' social inclusion.

\subsection{Sample}

According to phenomenographic approach, sample selection has to be done to acquire the maximum variation in conceptions (Marton, 1995; Trigwell, 1997). In this respect Lincoln and Guba (1985) state that redundancy of information determines the sample size. In addition Sandberg (2000) argues that the sample size of phenomenographic studies is around 30 for five theoretical conceptions. In this study (based on four conceptions of perceived increase of social inclusion according to figure 1) 32 participants were included in the sample, based on the observed repetition of explored information.

Two Regional Centres of Education in the Netherlands participated in the study ( $\mathrm{n} 1=15$ participants; $\mathrm{n} 2=17$ participants). All participants took part in the same category of courses, which primarily focussed on increasing basic skills of literacy in order to foster social inclusion. Table 1 gives an overview of the characteristics of the adult learners $(A L)$ involved in this sample. 
Table 1: Sample characteristics: Participants' background $(\mathrm{N}=32)^{1}$

\begin{tabular}{|c|c|}
\hline Characteristic / category & $\%$ \\
\hline \multicolumn{2}{|l|}{ Gender } \\
\hline Male & 53 \\
\hline Female & 47 \\
\hline \multicolumn{2}{|l|}{ Marital status } \\
\hline Married & 41 \\
\hline Unmarried & 38 \\
\hline Living together & 16 \\
\hline Widowed & 6 \\
\hline \multicolumn{2}{|l|}{ Age } \\
\hline $21-40$ & 38 \\
\hline $41-60$ & 47 \\
\hline $61-80$ & 9 \\
\hline \multicolumn{2}{|l|}{ Current level of education } \\
\hline $\mathrm{A} 0-\mathrm{A} 1^{2}$ & 13 \\
\hline A1 & 31 \\
\hline $\mathrm{A} 1-\mathrm{A} 2$ & 25 \\
\hline A2 & 28 \\
\hline $\mathrm{A} 2-\mathrm{A} 3$ & 3 \\
\hline \multicolumn{2}{|l|}{ Employment status } \\
\hline Unemployed & 46.9 \\
\hline Employed (paid job) & 53.1 \\
\hline \multicolumn{2}{|c|}{ Teacher's expectation of increase of social inclusion } \\
\hline Low & 50 \\
\hline High & 50 \\
\hline
\end{tabular}

\subsection{Method of data collection: Procedure}

Taking the guidelines of the phenomenographic approach in educational research into account the interview technique used, is open and deep, referring to the guidance by the response of the interviewees and the encouragement to discuss the conceptions of the interviewees relating to the phenomenon (Booth, 1997). In this study the interviewees were asked to discuss their interpretations of increase of social inclusion and the possible influence of the learning environment.

In order to overcome possible subjective interpretation of answers of the interviewees a team of seven researchers conducted the interviews (after a collective instruction on both locations). Each participant was individually interviewed during one hour by one researcher in the Regional Centre of Education where he or she was studying. The interview questions were reviewed by a team of experts in the field of adult education. Based on this review process, some terms were adapted in order to enhance the understanding of questions among the low skilled adult learners. The interview was based on six questions to explore the different conceptions of (change in) social inclusion. In order to ensure a valid and 
reliable answer, each question was asked separately and clinically and was only used to reach a more in-depth answer to the experienced phenomenon. These questions are:

1. How do you feel now? By looking back on the time before attending this course and the present day, did you feel different then? Can you give an example? (Referring to internalisation and connection as an indicator of increase of social inclusion.)

2. Do you join activities during the week or in the weekends? Are they different then when you compare this to the time before the course? Can you give an example? (Referring to participation and connection as an indicator of increase of social inclusion.)

3. How do you cope with things in life: independently or getting help from others. Does it differ with the time before the course? Can you give an example? (Referring to activation as an indicator of increase of social inclusion.)

4. Thinking back on the program you have been participating in and the aforementioned changes in your daily life (in what is changed what you're doing different now, what you can do nowadays or whom you have met), what has been a real help to you? Can you mention things that really helped during learning? (Referring to influential factors of increase of social inclusion.)

5. Have you experienced problems during participating in the program? If so, what was the cause of it? (Referring to barriers of increase of social inclusion.)

6. Do you have any tips for the Regional Centre of Education to improve things? If so, can you give an example?

Besides these prepared questions, a few probing questions were made for a more in-depth interrogation of the experience of the adult learner.

To prevent possible biases of the interviewers and interviewees a "checklist" consisting of the six questions of Dey (1993) was used for instructing the interviewers (see figure 2). This was used to ensure an optimal and comparable situation when interviewing the interviewees. 


\section{Figure 2: Checklist of Dey (1993) to prevent biases during phenomenographical study}

Question 1: Are the data based on the own observations / hearings, or is it hearsay?

All the data are based on own hearings confirmed by the tapes made during the interviews.

Question 2: Is there corroboration by others of your observations (or hearings)?

Corroboration is made by confirming the (possible) outcome of a random selection of the adult learners by the responsible teachers.

Question 3: In what circumstances was an observation (or interview) made or reported?

Every interview is done in the same circumstances referring to the comparable settings of the Regional Centre of Education where the learning process of each participant took place.

Question 4: How reliable are the people providing the data?

Every participant is selected by the responsible teachers according to the guidelines to find a balance in people who experience on the one hand a high rate of social inclusion and a low rate on the other.

Question 5: What motivations might have influenced a participant's report?

Possible motivations are an overestimating of reached rate of social inclusion. To overcome this bias participants were

asked to support their experiences by concrete examples of daily life.

Question 6: What biases might have influenced how an observation or hearing was made or reported? The interviewer for showing a better rate of social inclusion than experienced by the learner can do possible biases.

Therefore all interviews were taped to confirm the written down experiences of the learners.

\subsection{Data analysis: Analysis of phenomenographic transcripts}

The 32 interviews were taped and transcribed. Each transcript had the same format such as to make them comparable for analysis and to prevent the research team getting lost in the different texts.

To realise a detailed and highly qualitative analysis, we followed the different steps in analysing transcripts of a phenomenographic research as described by Marton et al. (1997). In order to ensure that the interpretations of the interviewee's experiences were not biased, the researcher's preconceptions were bracketed by investigator triangulation and peer review (Eisner, 1998). With respect to investigator triangulation, in the first phase of analysis each member of the researchteam $(n=6)$ individually read a selection of the transcript and pooled the perceptions of the interviewees into categories of descriptions of each interviewee independently. Before "this pool of meaning" (Bowden, 2000) discussion, debates and negotiations concerning the interpretations of perceptions of the interviewees were necessary. Accordingly, segments in each transcript were identified by giving them a heading. Then this selection of the transcript was analysed collectively by the team. Based on the results of this mediation process, the different categories of descriptions were defined. After achieving consensus among the researchers, categories of conceptions were formed (Marton, 1992). 
In the second phase of the analysis, a peer review was done in order to overcome intersubjectivity and to describe a framework based on the different descriptions of increase of social inclusion and its possible influence on the learning environment. An expert in social inclusion also read all transcripts and pooled the perceptions of the interviewees into categories with the same meaning concerning the increase of social inclusion. According to Marton (1992) this ordered set of descriptions is called the "outcome space" of the phenomenon.

\section{Results}

Based on the results of the analysis of the interviews, four qualitative different conceptions of (increase of) social inclusion can be discerned. Each conception has to be seen as a holistic interpretation of the above mentioned perceptions of the adult learners. Summarising the system of categories of description, we can define the different ways of experiencing the phenomenon of the impact of joining programs of lifelong education on the participants' perception, of change in social inclusion. According to table 2 four conceptions can be made, namely:

1. Increase of mastery

2. Increase of the feeling of having a stronger identity

3. Increase in social mobility

4. Increase of and improvement in relationships

Regarding our phenomenon the increase of social inclusion after joining education, these four conceptions are reflected by four elements of the learning environment, (see table 2), namely:

1. Life-circumstances

2. Teacher support

3. Learning contents and -activities

4. Self-directedness 
Table 2: Conceptions of social inclusion, described in terms of themes of the learning environment

\begin{tabular}{|c|c|c|c|c|}
\hline Themes & Conceptions & & & \\
\hline & 1 & 2 & 3 & 4 \\
\hline & $\begin{array}{l}\text { Mastery } \\
\text { (Activation) }\end{array}$ & $\begin{array}{l}\text { Identity } \\
\text { (Internalisation) }\end{array}$ & $\begin{array}{l}\text { Social Mobility } \\
\text { (Participation) }\end{array}$ & $\begin{array}{l}\text { Relationships } \\
\text { (Connection) }\end{array}$ \\
\hline Life-circumstances & $\begin{array}{l}\text { Managing daily life } \\
25 \text { Adult Learners }\end{array}$ & $\begin{array}{l}\text { Awareness } \\
24 \text { Adult Learners }\end{array}$ & $\begin{array}{l}\text { One's own initiative } \\
11 \text { Adult Learners }\end{array}$ & $\begin{array}{l}\text { One's own initiative } \\
16 \text { Adult Learners }\end{array}$ \\
\hline Teacher support & $\begin{array}{l}\text { Encourage to learn } \\
30 \text { Adult Learners }\end{array}$ & $\begin{array}{l}\text { Encourage to learn } \\
29 \text { Adult Learners }\end{array}$ & $\begin{array}{l}\text { Increase transfer } \\
12 \text { Adult Learners }\end{array}$ & $\begin{array}{l}\text { Increase transfer } \\
18 \text { Adult Learners }\end{array}$ \\
\hline $\begin{array}{l}\text { Learning contents } \\
\text { and -activities }\end{array}$ & $\begin{array}{l}\text { Constructivistic } \\
\text { perspective } \\
23 \text { Adult Learners }\end{array}$ & $\begin{array}{l}\text { Constructivistic } \\
\text { perspective } \\
23 \text { Adult Learners }\end{array}$ & $\begin{array}{l}\text { Constructivistic } \\
\text { perspective } \\
8 \text { Adult Learners }\end{array}$ & $\begin{array}{l}\text { Constructivistic } \\
\text { perspective } \\
13 \text { Adult Learners }\end{array}$ \\
\hline Self-directedness & $\begin{array}{l}\text { Intrinsic motivation } \\
11 \text { Adult Learners }\end{array}$ & $\begin{array}{l}\text { Intrinsic motivation } \\
11 \text { Adult Learners }\end{array}$ & $\begin{array}{l}\text { Extrinsic motivation } \\
4 \text { Adult Learners }\end{array}$ & $\begin{array}{l}\text { Extrinsic motivation } \\
4 \text { Adult Learners }\end{array}$ \\
\hline
\end{tabular}

The four conceptions form the "outcome space" of our study. According to table 2 some of the interviewees experience more than just one conception of increase of social inclusion. For example AL 3 experiences an increase of mastery (activation) in combination with an increase of the feeling of having a stronger identity (internalisation), having more possibilities of social mobility (participation) and having more and better relationships (connection). Concretely, the results show that for the interviewees in our study, the increase of mastery (conception) is the most reachable goal to increase social inclusion. Likewise increase of the feeling of having a stronger identity (conception 2 ) is reachable for almost all the adult learners except for one (see table 2). On the contrary, conceptions referring to the relationship with the interviewee with his environment, increase of social mobility (conception 3) and increase of and improvement in relationships (conception 4) are less experienced by the adult learners. See table 2 for the increase of social mobility (conception 3) as the less reachable or desirable for the adult learners (see table 2). In the next section, we will describe the four conceptions of social inclusion that emerged from the interviews.

\subsection{Conception 1: Increase of mastery}

As a result of the increase of social inclusion, all adult learners experience an increase in mastery. In this context they interpret mastery as a better control of their own life, "a beginning of understanding things, a little bit of reading and writing to prevent living in a black hole"(AL14). In other words, AL14 feels less isolated. In this context, vulnerable adults avoid the confrontation of not being able to do things. On the contrary, after joining a course one felt less ashamed and did not deny their problems anymore, but "dare to give their own 
opinion. Also in reading letters, saying that they don't dare to read it. Before, they just gave it away by saying that the other should read it, because they still didn't understand it" (AL10).

Furthermore, the increase of mastery means an increase in problem solving. Adult learners perceive an increase in the ability to read after the course. Referring to this ability, they write things down instead of using violence in order to stand up for their rights. In other words, adult learners like AL9, experience aggression in the past, because of their disability to read or write. According to AL9 he "hit our own "director of cleaning" in his own office, because he cheated him. He wanted to write it down, but he couldn't. He always needed a lawyer. Always waiting for them to do things. But now he can read. He restrains his anger"(AL9). Besides problem solving, adult learners experience more knowledge of the world and more skills for living their life. For example taking money from the banking machine or managing their own administration. Therefore, a greater understanding gives a feeling of being autonomous. In this context, the causes of feeling autonomous are the increased reading and digital skills as explained by AL23 when buying a dishwasher. "I did this by myself. I surfed to www.marktplaats.nl and sought for a dishwasher. I saw an advertisement, made a phone call (by myself) and bought a dishwasher for 75 Euro"(AL23). Concerning reading skills, adult learners are now able to read to their grandchildren, support their kids in making their homework and can read subtitles on television, instead of having to listen to their partner reading to them. In order to control their own life this is one of the basic needed skills. Except for reading skills, increase of mastery includes an impact on daily life and work as a result of school. This is illustrated by AL 16. "Yes, of course. Now I can write a shopping list on my own. And I can write down things that happen at work"(AL16).

\subsection{Conception 2: Increase of the feeling of having a stronger identity}

Since following an adult education course, adult learners describe the outcome as a kind of self-development; they are aware of their own progress. Consequently one experiences an increase of self-confidence based on new trust: "I feel better now, I have more selfconfidence"(AL28).

Because of the increase in self-confidence, adult learners reveal an increase in their selfesteem. AL5 for example experienced the course as a support in becoming a stronger person. "Before I came here, I felt uncertain about myself. I didn't dare to talk and therefore I felt uncertain. (...) Now I'm going to school and I learn with other people, as I don't want to be the same pathetic person. But it helped very well, very well"(AL5).

At any rate the example of AL5 shows a kind of self-reflection on the increased feeling of self-respect. Concerning this increase of self-respect, perceptions of increase of social inclusion of the adult learners refers to respecting yourself and being someone in a group. In this context they are able to identify themselves with peers or group members and feel a sense of belonging to a group and being able to contact them for support, as is illustrated by 
AL4 saying that it is "supportive". "You ask something if you don't understand it. I think it's important, but not always. You have to be independent, but sometimes it's good to cooperate"(AL4). The feeling of belonging to a group and feelings of safety seem to occur, because of an increase of social inclusion. Adult learners feel less insecure. Regarding the example of AL24's perception, a decrease of insecurity can mean overcoming your fear of being laughed at. "Eight months ago I thought they were laughing at me, but now I know that it's not the case. They laugh about a situation or other people"(AL24).

Accordingly an increase of security can cause a more pro active attitude. In this case adult learners become less withdrawn and are more assertive in doing things. Likewise these adult learners experience an increase in daring. In this context they dare to speak out, to make a phone call, to write to an official organisation or to drive a car. Such as AL12 who explains that she "didn't dare to drive". "Now I'm driving a car. I thought that I couldn't read those things at the side of the road quick enough and that I would take the wrong way. But now I manage it a little bit"(AL12).

Due to a greater sense of identity adult learners perceive an enrichment of life and are happier in life. In order to experience a greater sense of happiness these adult learners describe a reduction of their shame for having some problems. "I think it's because of my accident that it's hard for me to read or write. I admit it; I will not keep my mouth shut. And I try to admit it to people who are ashamed of themselves and to show that one can do it differently. You can be helped"(AL19).

\subsection{Conception 3: Increase of social mobility}

Besides the increase of mastery and the feeling of having a stronger identity, social mobility means an increase of social inclusion on a more collective level. In this case adult learners experience an enhancement of being involved in society as explained by AL17 with the example of "going to the town hall." "Now it's really different. Now I'm in contact with people in the town hall, the post office, and the bank. I can do everything by myself"(AL17). The increase of social mobility means expanding the boundaries of the individuals' surroundings. According to adult learners, they had not visited unknown places before joining the course. According to AL8 this is the case for example by going to a shop. "I never dared to do that. But now I like to sit on a terrace and drink a cup of coffee and order bread or something to eat after visiting my mother. I never used to do that, but now I like to do it. I feel comfortable going by bus, tram or metro"(AL8).

Other than using public transport like AL8, adult learners, as for example AL17, describe their increase in social mobility by taking up a hobby in a new place instead of staying at home. "Now I can choose my hobbies. My real hobby is to trade in cars"(AL17). However, hobbies are not the only aspect of an increased social mobility. Besides taking up hobbies, adult learners join and participate in voluntary work after and during the courses. To be more precise, AL3 became an ambassador for stimulating other people to join courses. 
"I had to explain why I'm still at school. I had to stimulate anxious people to go to school. That is verbally, because a leaflet doesn't work for people who can't read"(AL3).

\subsection{Conception 4: Increase of and improvement in relationships}

Similar to an increase in social mobility, an increase in relationships means a greater focus on society. More than half of the adult learners described the increase of social inclusion as a kind of increase or improvement in relationships. Focussing on the increase of social relationships, adult learners experience less social inhibitions when making new contacts. "Yes, if you're joining the course in becoming an ambassador then you visit other people who also experience problems in reading and writing"(AL30).

Due to meeting other people the adult learners claimed a significant decrease in social exclusion. Therefore the risk of making new contacts grew. Considering these new contacts, AL16 said for example that he made new friends. "Yes, you meet more and more people. I came here at the same time with $\mathrm{J}$. and that was the beginning of a friendship. From the very first day. If he's not here I call him asking what's the matter. It's just a kind of a friendship"(AL16). Regarding making new friends, intimacy was possible to some extent for the adult learners. In this context cosiness increased. Consequently, a sensitive capacity to help each other was enhanced, which resulted in mutual support as experienced by AL13 "by helping each other a little bit. Yes, you're really a kind of family to each other"(AL13). Besides the increase of mutual support as seen as an increase of social inclusion, the improvement and increase of relationships is perceived as an increase in social cohesion. To be more precise, people are more bound to each other, because it is easier to talk to and live with each other, as for example AL17 who has "contact with the neighbour and the neighbour's wife"(AL17).

Other people like AL5, prefer to drink coffee with others in order to increase their language ability and their contacts with their direct surroundings. More explicit, AL 5 noticed that she "has not enough contact with Dutch people, that's a problem. That's why I'm here. If I spoke Dutch I didn't have to be here. And she said to me she understood it. And I'm still going to that lady. Now I only talk to her. Just to drink a cup of coffee or something like that"(AL5). In addition to an increase in relationships, one interviewee talked about improvement of existing contacts. Hence the adult learners learned to understand different cultures like AL26 who "had a different view of Dutch people. I think they're more democratic. You talk about everything"(AL26).

\subsection{Influences of the learning environment}

In addition, the analyses of the interviews showed the existence of different influential factors on the increase of the processes of social inclusion varying from teacher support to 
self-directedness and from life-circumstances to learning contents and -activities (see table 2).

As is shown in table 2 extrinsic influential factors, to be mentioned life-circumstances of the participant, teacher support and the characteristics of the learning contents are experienced as the most important in order to reach increase of social inclusion. Differences between categories will be explained in the following paragraphs. Furthermore teacher support seems to be the influential factor experienced by almost every adult learner. Regarding adult learners' experiences, self-directedness seems to be less important in order to increase social inclusion.

Firstly life-circumstances (for example, support by people in the direct surroundings) seems to be an important influential factor on the increase of social inclusion as perceived by 25 learners involved, but differs for three of the four conceptions. For the first conception it can be explained as supportive for managing daily life, as for example in driving a car. "My wife helped me very well. Even in getting my driving licence. Yes, we had to learn day and night to get it"(AL1). This example shows that the management of daily life is one of the most important result of the support of the life environment during learning. Besides this, for the conception "increase of the feeling of having a stronger identity", the life environment makes the interviewee aware of the progression and the need of learning. To be more specific, AL11 experiences this family support. "My parents and girlfriend noticed a lot of progression. (...) They told me that they used to help me, but that it is not necessary anymore"(AL11). Thirdly, life-circumstances can challenge the learner to do things on her or his own initiative, which seems to be the role of the life environment during the conceptions "increase of social mobility" and "increase of and improvement in relationships". AL19 explains this support: "I went to the school of my youngest daughter and told her teacher and the headmaster that I was illiterate and that it was hard for me to read and write. I wanted to do something with it. So now, we are active and busy at school." (AL19).

Secondly, teacher support seems to be an important cause for the perceived increase of social inclusion by almost every adult learner. The kind of teacher support seems to differ for the conceptions "increase of mastery" and "increase of the feeling of having a stronger identity" in comparison with the conceptions "increase of social mobility" and "increase in and improvement of relationships". For interviewees referring to an increase of mastery (conception 1) and an increase of the feeling of having a stronger identity, teacher support implies encouragement to learn. "And if I do not know it, I will ask the teacher. Then I will ask her to help me, because I do not know it. And then she will write on the blackboard and explain it. So you will be helped in the way you like it. Yes, in the way I like it."(AL1). Or, as AL9 explains, who perceived the support of his teacher as inevitable and "trusted the teacher." "She just explained it to me and she appreciated me. I would sometimes say: "Fool, I already explained that." She didn't and that's why I appreciate that woman so much" (AL 9). In this example AL9 explains the importance of being praised by the teacher to being motivated in continuing the course. When elaborating on an increase in social mobility and in 
relationships, the interviewees refer to the teacher who guides the adult learner in overcoming daily problems by stimulating transfer. AL5 for example explains that the teacher takes time for his problem. "A teacher does not only look at the letters, at the writing, but also at your problem. (...) She talks and asks what is going on: Are you feeling well? Why not? Just give it a try"(AL5). The aforementioned quotes about the different conceptions of social inclusion underline the different roles of teachers in adult education programs.

Thirdly, besides the impact of life-circumstances and teacher support, for some learners like AL10 some features of the learning contents and -activities are inevitable to the enhancement of social inclusion. "That's the same as I learned at school. (...) How to fill in forms concerning complaints or changing health insurance"(AL10). This quote refers to the relevance of offering an authentic learning environment, a core constructivistic learning principle (Tenenbaum et al., 2001). The descriptions of the interviewees reveal that the authenticity of the learning environment is important for increasing social inclusion, no matter which conception the interviewees hold. For example, the understanding of a subject matter. "Most important is the content of the lesson. Learning to understand everything. Therefore you must read well first. That suits me well. Lately we covered a whole lesson about the importance of medicine. How much medicines people use. Then I figure it out pretty quick"(AL16). According to AL16, theory and practice are combined. The contents of using medicine is translated into daily practice and targeted towards solutions. In addition to authenticity, sharing of ideas and discussions are mentioned by the interviewees as enhancing the four different social inclusion effects of participating in adult education programs. Also these characteristics of a learning environment are described as constructivist learning principles (Tenenbaum et al., 2001). For example, AL9 defines the learning activity as: "He says: "You have to write more. If you write more than you do the same as I do. It just succeeds." So that supports me, just the two of us. Then we talk about all kind of things. That man lives in the village, where I was born"(AL9).

Finally, eleven learners became involved in learning because they could direct their own learning process and their involvement in learning. There seems to be a distinction as to the way self-directedness of learning is established. For interviewees referring to an increase in mastery and an increase in the feeling of having a stronger identity, there seems to be an intrinsic motivation to join learning and influence their own learning process. AL9 underlines this by saying "For myself. I'm doing this for myself"(AL9). Likewise AL8 says "it's because of me"(AL8). "But look, if you want you, you will succeed. That is really true. If you intend to go for it and you go for it one hundred percent then it will succeed. (...) You have to give yourself completely"(AL8). According to AL8 it is necessary to direct your own learning. This can be formulated as an optimum level of self-directed learning. On the other hand when interviewees refer to an increase in social mobility and relationships, they refer to an external motivation, because they experience the social need of joining and directing their own learning process. Regarding the changing society and their perceived lack of abilities to cope with problems in daily life, they seem to understand the need of learning, like AL6. "I'm 
doing it, because I want that. Yes, because I can see that you need it in society. Because if you can't, you won't get through it. Then you depend on other people. And want to try to be independent"(AL6).

\section{Conclusions and discussion}

The experience of social inclusion resulting from participating in adult education programs, as described by the 32 adult learners in our phenomenographic study, show similarities and differences between the individual participants. The conceptions of social inclusion reflect the quadrant of social inclusion as described in literature: activation, internalisation, participation and connection. Furthermore the results indicate that increase on an individual level (activation and internalisation) is more often perceived by the interviewees than an increase on the collective components of social inclusion (participation and connection).

Our results partly confirm earlier findings of Reder (2009), who indicate that participation in skills programs affect engagement in literacy and numeracy practices. Besides this Reder (2009) points out that age and place of birth seem to be the most important influential factors on the rate of change of proficiency of numeracy and literacy. On the contrary our results point out that most adult learners experience necessary support by the learning environment, for example by the teacher. Our findings seem to indicate that participants in lifelong learning programs seem to experience the characteristics of the learning environment as necessary in order to increase social inclusion.

Furthermore earlier research in the field of human resource development has paid attention to factors that might enhance the transfer of what is learned in the classroom to daily practice. In a former study, we have argued on the validity of these factors for adult education aiming to increase social inclusion of its participants. The results of the study presented here confirm the relevance of four factors for enhancing social inclusion as conceived by the interviewees: life-circumstances, teacher support, learning contents and activities and self-directed learning. Regarding transfer of training studies (Baldwin and Ford, 1988; Cheng and Ho, 2001; Thijssen, 2001; Holton, Chen and Naquin, 2003; Nijman, 2004; Nijhuis, Segers and Gijselaers, 2005; Cheng and Hampson, 2008) the trainee him- or herself, the training program and the environment in which transfer of training takes place are the three most important variables influencing transfer of training. According to our findings the adult learners experience life-circumstances (seen as part of the environment), selfdirectedness (referring to the trainee him- or herself) and the learning contents and activities (seen as the training program) as important for their increase of social inclusion. On the contrary our findings indicate that the influence of teacher support was commonly shared between all 32 adult learners. This finding seem to differ from results of transfer of training studies (Baldwin and Ford, 1988; Cheng and Ho, 2001; Thijssen, 2001; Holton, Chen 
and Naquin, 2003; Nijman, 2004; Nijhuis, Segers and Gijselaers, 2005; Cheng and Hampson, 2008) in which findings indicate less importance of the support of the teacher.

For future research, we suggest cross cultural studies in order to be able to generalise the findings of this study, which was conducted in a Dutch context. Because each country has different educational systems and approaches with varying targetgroups, differences in conceptions of the phenomenon of social inclusion as well as of influential factors in the learning environment can be expected (Consortium EDAM, 2010).

Furthermore with respect to this phenomenographic study, we have gained more insights and evidence concerning the meaning of increase of social inclusion as perceived outcome of lifelong learning programs. This is an important step in mapping outcome of lifelong learning programs in terms of social inclusion as discussed by Partridge (1999). Quantitative research and statistical analysis can be a suitable methodology in order to gain further insights in the impact of lifelong learning programs on the increase of social inclusion.

Finally according to our results the adult learners seem to perceive teacher support as an important characteristic of the learning environment in order to increase social inclusion. Pratt (1998) argues that teachers' conceptions can influence the daily classroom practice of adult education. Exploring teachers' conceptions of social inclusion, effects of adult education seem to be relevant in gaining insights in the possibilities of effective support for adult learners in order to increase their social inclusion.

In summary, according to our findings lifelong learning might possibly be a lever for achieving a better position in present day society. The hierarchical structure of these findings can be seen as a first step in gaining insight in outcome of lifelong learning programs in terms of social inclusion. This can be helpful to understand the possibilities of optimising the quality of lifelong learning programs in order to reach significant outcome for adult learners.

\section{References}

Aguinis, H., \& Kraiger, K. (2009). Benefits of training and development for individuals and teams, organizations, and society. Annual Review of Psychology, 60, 451 - 474.

Allen, T. \& Kiiver, H. (2011). Euro area unemployment rate at 10.1\%. Brussels: Eurostat.

Alvarez, K., Salas, E., \& Garofano, C.M. (2004). An integrated model of training evaluation and effectiveness. Human Resource Development Review, 3 (4), 385 - 416.

Andrews, F. M. \& Withey, S. B. (1974). Developing measures of perceived life quality: Results from several national surveys. Social Indicators Research, 1974 (1), 26.

Antonucci, T. C. \& Akiyama, H. (2002). Aging and close relationships over the life span. International Society for the Study of Behavioural Development Newsletter (1, Serial No. 41), 2 - 5.

Antonucci, T. C. Lansford, J. E. \& Akiyama, H. (2001). The impact of positive and negative aspects of marital relationships and friendships on the well-being of older adults. In J. P. Reinhardt (Ed.), Negative and positive support. Mahwah, NJ: Erlbaum. 
Antonucci, T. C., Vandewater E. A. \& Lansford, J. E. (2000). Adulthood and aging: Social processes and development. In A. Kazdin (Ed.), Encyclopedia of Psychology Washington. DC \& New York: American Psychological Association and Oxford University Press.

Baldwin, T. T. \& Ford, K. J. (1988). Transfer of training: A review and directions for future research. Personnel Psychology, 1988 (41), 43.

Bandura, A. (2001). Social cognitive theory. Annual Review of Psychology. Vol. 52. In J. W. Santrock (2008), Life-span development. New York: McGraw-Hill, 46 - 47.

Bandura, A. (2004). Toward a psychology of human agency. Paper presented at the meeting of the American Psychological Society, Chicago. In J. W. Santrock (2008), Life-span development. New York: McGraw-Hill, 46 - 47.

Bandura, A. (2006a). Going global with socio cognitive theory: From prospect to paydirt. In S. I. Donaldson, D. E. Berger \& K. Pezdek (Eds.), The rise of applied psychology: New frontiers and rewarding careers. Mahwah, NJ: Erlbaum. In J. W. Santrock (2008), Life-span development. New York: McGraw-Hill, 46 - 47.

Bandura, A. (2006b). Toward a psychology of human agency. Perspectives of Psychological Science, 1 (2), $164-180$.

Ben-Zur, H. \& Michael, K. (2007). Men's affective reactions life events: the roles of coping strategies and personal outcomes. The Journal of Men's Health \& Gender, Vol. 4 (3), 358.

Booth, S. (1997). On phenomenography, learning and teaching. Higher Education Research \& Development, 16 (2), 134 - 158. In A. Wright, J. P. Murray \& P. Geale (2007). A phenomenographic study of what it means to supervise doctoral students. Academy of Management Learning \& Education, 6 (4), p. 461.

Bowden, J.A. (2000) The nature of phenomenographic research. In Bowden, J.A. \& Walsh, E. (Eds.) Phenomenography. RMIT University, Melbourne, p. 1 - 18.

Breakwell, G. M. (1986) Coping With Threatened Identities. London: Methuen.

Breakwell, G. M. (1988) Strategies adopted when identity is threatened. Revue Internationale de Psychologie Sociale, 1 (2), 189 - 203.

Brennan, K. A., Clark, C. L., Shaver, P. R. (1998). Self-report measurement of adult romantic attachment: An integrative overview. In J. A. Simpson \& W. S. Rholes (Eds.), Attachment theory and close relationships. New York: Guilford Press. In J. W. Santrock (2008), Life-span development. New York: McGraw-Hill, 497.

Brinkerhoff, R. O., and M. U. Montesino (Fall 1995). Partnerships for transfer of training: Lessons from a corporate study. Human Resource Development Quarterly, 6 (3), 263-274.

Burke, L. A. \& Hutchins H. M. (2007). Training transfer: An integrative literature review. Human Resource Development Review 6 (3), 263 - 296.

Campbell, C. P., \& Cheek, G. D. (1989). Putting training to work. Journal of European Industrial Training, $13(4), 32-36$.

Carstensen, L. L. (1995). Evidence for a life-span theory of socioemotional selectivity. Current Directions in Psychological Science, 4, 151 - 156. In J. W. Santrock (2008), Life-span development. New York: McGraw-Hill, 651 - 652. 
Carstensen, L. L. (1998). A life-span approach to social motivation. In J. Heckhausen \& C. Dweck (Eds.), Motivation and self-regulation across the life-span. New York: Cambridge University Press. In J. W. Santrock (2008), Life-span development. New York: McGraw-Hill, 651 - 652.

Carstensen, L. L. (2006). The influence of a sense of time on human development. Science, 312, 1913 1915. In J. W. Santrock (2008), Life-span development. New York: McGraw-Hill, 651 - 652.

Cheng, E. W. L. \& Hampson, I. (2008). Transfer of training: A review and new insights. International Journal of Management Reviews 10 (4), 15.

Cheng, E. W. L. \& Ho, D. C. K. (2001). A review of transfer of training studies in the past decade. Personne/ Review, 30 (1), 17.

Christian, D. E. (1974). International Social Indicators: The OECD Experience. Social Indicators Research 1 (2), 169.

Colley, D. G. (1975). A social change index - an objective means to discern and measure the relative current social condition of cities, towns, and their sub-communities. Social Indicators Research, 1975 (1), 26 .

Consortium EDAM. (2010). Learning Environment and Social Inclusion for marginalised and vulnerable adults: Desk Research. Maastricht: EDAM.

Cromwell, S. and Kolb, J. (2004). An examination of work environment support factors affecting transfer of supervisory skills training to the work place". Human Resource Development Quarterly, 15 (4), 449 71.

De Jong-Gierveld, J. (1987). Developing and testing a model of loneliness. Journal of Personality and Social Psychology, 5, 119 - 128.

Dey, I. (1993). Qualitative data analysis. New York: Routledge.

Eisner, E. W. (1998). The enlightened eye: Qualitative inquiry and the enhancement of educational practice. Upper Saddle River, NJ: Merrill / Prentice-Hall.

Endler, N., S. \& Magnusson, D. (1976). Toward an interactional psychology of personality. Psychological Bulletin, 83, 956 - 974.

European Commission (2007). Non-Vocational Adult Education in Europe Executive Summary of National Information on Eurybase Working Document, 2010. 21-04-2010. <eacea.ec.europa.eu/ressources/eurydice/pdf/0 . . /083EN.pdf>.

European Commission (2008). Communication from the Commission to the European Parliament, the Council, the European Economic and Social Committee and the Committee of the Regions. An updated strategic framework for European cooperation in education and training, 2010. 21-04-2010. <ec.europa.eu/education/lifelong-learning . . . /com865_en.pdf > .

Fortuin, K. \& Keune, C. (1997). Anders praten over jeugd: Naar een begrippenkader voor preventief jeugdbeleid. Utrecht: Verwey-Jonker Instituut.

Guildford, J. (2000). Making the case for social and economic inclusion. Canada Atlantic Region: Population and Public Health Branch.

Harris, L.R. (2011). Phenomenographic perspectives on the structure of conceptions: The origins, purposes, strengths, and limitations of the what/how and referential/structural frameworks. Educational Research Review, vol. 6, 109 - 124.

Hogg, M. A. \& Abrams, D. (1988). Social Identifications. London: Routledge. 
Holton, E. F., Chen H. \& Naquin, S. S. (2003). An examination of learning transfer system characteristics across organizational settings. Human Resource Development Quarterly, vol. 14 (4), 24.

Howitt, D. \& Cramer, D. (2008). Introduction to Statistics in Psychology. Harlow: Prentice Hall.

Huisman, J., Pijls, T., Van Hoeij, J., Van Voorst van Beest, K., Boonaerts, Y. \& Lens, M. (2003). Portfolio sociale competenties: Primair onderwijs, vmbo, mbo. 's-Hertogenbosch: CINOP.

Hutcheson, G. \& Sofroniou, N. (1999). The multivariate social scientist. London: Sage.

Hutchins, H. M. \& Burke, L. A. (2006). Has relapse prevention received a fair shake? A review and implications for future transfer research. Human Resource Development Review, 5 (1), 8 - 25.

Knowles, M. S. (1975). Self-directed learning: A guide for learners and teachers. New York: Association Press.

Kramer, R., Hanna, B., Su, S. \& Wei, J. (2001). Collective identity, collective trust and social capital: Linking group identification and group cooperation. In M. Turner (Ed), Groups at work. London: Erlbaum.

Krauss Whitbourne, S. (2005). Adult development \& aging: Biopsychological perspectives. Hoboken: John Wiley \& Sons, Inc.

Krueger, R. F., South, S. ,Johnson, W. Iacono, W. (2008). The heritability of personality is not always $50 \%$ : Gene-environment interactions and correlations between personality and parenting. Journal of Personality, 76, 1485 - 1522.

Levitas, R., Pantazis, C., Fahmy, E., Gordon, D., Lloyd, E. \& Patsios, D. (2007). The Multidimensional analysis of social exclusion. London: Department for Communities and Local Government.

Lincoln, Y. S. \& Guba, E. G. (1985). Naturalistic inquiry. Beverly Hills, CA: Sage. In D. Ary, L. C. Jacobs \& A. Razavieh. (2002). Introduction to Research in Education. Belmont CA: Wadsworth Group, p. 430.

Liu, B. (1974). Quality of life indicators: a preliminary investigation. Social Indicators Research, 1974 (1), 22, 187 - 208.

Main, M. (1979). Social and personality-development. Contemporary Psychology, 24 (8), 11.

Markus, H. \& Nurius, P. (1986). Possible selves. American Psychologist, 41, 954 - 969. In S. Krauss Whitbourne (2005), Adult development \& aging: Biopsychological perspectives. Hoboken: John Wiley \& Sons, Inc., 259.

Marton, F. (1992) Phenomenography and "the art of teaching all things to all men". Qualitative Studies in Education, 5, 253 - 267.

Marton, F. (1995). On non-verbal learning. Level of processing and level of outcome. Scandinavian Journal of Psychology, (16), 273 - 279. In A. Wright, J. P. Murray \& P. Geale (2007). A phenomenographic study of what it means to supervise doctoral students. Academy of Management Learning \& Education, 6 (4), p. 460.

Marton, F. \& Booth, S. (1997) Learning and awareness. Mahwah, N. J.: Lawrence Erlbaum.

Marton, F., Watkins, D. \& Tang, C. (1997). Discontinuities and continuities in the experience of learning: an interview study of high-school students in Hong Kong. Learning and Instruction, vol. 7 (1), 21 - 48.

Mastergeorge, A. M. (2001). Guided Participation in sociocultural learning: Intervention and apprenticeship. Academic Search Premier, 22 (1), 14.

McClusky, H., Y. (1970). A dynamic approach to participation in community development. Journal of Community Development Society, 1970, 1, 8. 
McGivney, V. (1992). Tracking adult learning routes: A pilot investigation into adult learners'starting points and progression to further education and training. Leicester: National Institute of Adult Continuing Education.

Nickell, S., Nunziata, L. \& Ochel, W. (2005). Unemployment in the OECD since the 1960s: What do we know? The Economic Journal, (115), 1-27.

Nijhuis, J. F. H., Segers, M. S. R. \& Gijselaers, W. H. (2005). Influence of redesigning a learning environment on student perceptions and learning strategies. Learning Environments Research, 2005 (8), 27.

Nijman, D.J.J.M. (2004). Supporting Transfer of Training: Effects of the Supervisor. Enschede: Universiteit Twente.

Nilsson, A. (2010). Vocational education and training - an engine for economic growth and a vehicle for social inclusion. International Journal of Training and Development, 14, 4, 251-272.

Nye M. \& Hargreaves, T. (2009). Exploring the Social Dynamics of Proenvironmental Behavior Change: A Comparative Study of Intervention Processes at Home and Work. Journal of Industrial Ecology, vol. $14(1), 137$.

Ogg, J. (2005). Social exclusion and insecurity among older Europeans: the influence of welfare regimes. Ageing \& Society, 25, 69.

Partridge, M. (1999). Monitoring Adult Education: Monitoring adult education for knowledge-based policymaking. Hamburg: Druckerei Seemann.

Pham, N.T.P. (2010). Facilitating Training Transfer Effects. Maastricht: Océ Business Services.

Pham, N.T.P., Segers, M.S.R. \& Gijselaers, W.H. (2010). Effects of the Work Environment on Training Transfer Effects: the case of Master Business Administration (MBA) in Vietnam. In International Journal of Training and Development (Under review).

Pratt, D. D. (1998). Five perspectives on teaching in adult and higher education. Malabar, Florida: Krieger Publishing Company.

Priemus, H. (2005). Het spel en de knikkers: Fysieke en sociale pijler verbonden. Tijdschrift B\&G / Uitgave Bank Nederlandse Gemeenten en Vereniging van Nederlandse Gemeenten, 2005 (1), 5.

Raemdonck, I. (2006). Self-directedness in learning and career processes: A study in lower-qualified employees in Flanders. Gent: Universiteit van Gent.

Ryan, R. M. \& Deci E. L. (2000). Self-determination theory and the facilitation of intrinsic motivation, social development, and well-being. American Psychologist, vol. 55 (1), 11.

Reder, S. (2009). The development of literacy and numeracy in adult life. In S. Reder \& J. Bynner (Eds.), Tracking adult literacy and numeracy skills. New York: Routledge, 59 - 84.

Renshaw. P.D. (2003). Community and learning: Contradictions, dilemmas and prospects. Discourse: Studies in the Cultural Politics of Education 24, (3), 355 - 370.

Sandberg, J. (2000). Understanding human competence at work: An interpretative approach. Academy of Management Journal, 43 (1), 9 - 25. In A. Wright, J. P. Murray \& P. Geale (2007). A phenomenographic study of what it means to supervise doctoral students. Academy of Management Learning \& Education, 6 (4), 460 - 461.

Santrock, J. W. (2008). Life-span development. New York: McGraw-Hill. 
Scharf, T., Phillipson, C. \& Smith, A., E. (2005). Social exclusion of older people in deprived urban communities of England. European Journal of Ageing, 2, 76.

Serrano-García, I. \& Bond, M. A. (1994). Empowering the silent ranks: Introduction. American Journal of Community Psychology, 22 (4), 13.

Simons, R-J. S. \& Bolhuis, S. (2004). Constructivist learning theories and complex learning environments. In Mulder, R.H. \& Sloane, P.F.E., New approaches to vocational education in Europe. The construction of complex learning-teaching arrangements. Oxford: Symposium Books; and in Oxford Studies in Comparative Education, 13(1), 13 - 25.

Smith, M. K. (2007). Social capital. The encyclopedia of informal education, 2007. 26 - 07 - 2007. $<$ www.infed.org/biblio/social_capital.htm>.

Solarczyk-Ambrozik, E. (19). Socio-economic transformation and adult learning in Poland. In Bisovsky, G., Bourgeois, E., Bron, M., Chivers, G. \& Larsson, S., Adult learning and social participation. Wien: Verband Wiener Volksbildung, 373 - 385.

Sparkes, J. (1999). Schools, Education and Social Exclusion. London: CASE.

Steele, M.M. (2005, April 30). Teaching Students With Learning Disabilities: Constructivism Or Behaviorism? Current Issues in Education, 8 (10). Available <http://cie.ed.asu.edu/volume8/number10/>.

Sullivan, E. (2002). Social exclusion, social identity and social capital: Reuniting the global, the local and the personal. Discussion paper for the Conference de l'Association Internationale des Ecoles de Travail Social.

Tan, K.H.K. (2008). Qualitatively different ways of experiencing student self-assessment. Higher Education Research \& Development, vol. 27(1), 15 - 29.

Tenenbaum, G., Naidu, S., Jegede, O. \& Austin, J.(2001). Constructivist pedagogy in conventional on campus and distance learning practice: An exploratory investigation. Learning and construction 11, 25.

The World Bank. (2007). Social Exclusion and the EU's Social Inclusion Agenda: Paper Prepared for the EU8 Social Inclusion Study. Washington: The World Bank.

Thijssen, J. (2001). Personele flexibiliteit in strategisch perspectief: De betekenis van employability voor organisatie en individu. In R. Poell \& J. Kessels, Human Resource Development, Organiseren van het leren. Alphen aan den Rijn: Samsom, 103 - 116.

Trigwell, K. (1997). Phenomenography: An approach to research. Sydney: Hampden Press. In A. Wright, J. P. Murray \& P. Geale (2007). A phenomenographic study of what it means to supervise doctoral students. Academy of Management Learning \& Education, 6 (4), 460.

Van Houten, D. (2008). Werken aan inclusie. Tijdschrift Sociale Interventie, 17 (3), 45 - 56.

Van Lakerveld, J., Berg, J. van den, Brabander, C. de, \& Kessels, J. (2000). The corporate curriculum: a working-learning environment. In Proc. Annual Academy of Human Resource Development Conference: Expanding the Horizons of Human Resource Development. Raleigh-Durham NC.

Van Regenmortel, T. (2009). Empowerment als uitdagend kader voor sociale inclusie en moderne zorg. Journal of Social Intervention: Theory and Practice 18 (4), 22.

Verté, D., De Witte, N. \& De Donder, L. (2007). Schaakmat of aan zet? Monitor voor lokaal ouderenbeleid in Vlaanderen. Brugge: Uitgeverij Van den Broele. 
Van der Vlerk, D. (2005). Inspireren tot leren: Het ontwerpen van een uitdagende leeromgeving. Bussum: Uitgeverij Coutinho.

Wright, A., Murray, J. P. \& Geale, P. (2007). A phenomenographic study of what it means to supervise doctoral students. Academy of Management Learning \& Education, 6 (4), 458 - 474. 


\section{Chapter 3: Development of the SIT, an instrument to evaluate the transfer effects of adult education programs for social inclusion}

Published as De Greef, M., Segers, M. \& Verté, D. (2010). Development of the SIT, an instrument to evaluate the transfer effects of adult education programs for social inclusion. Studies in Educational Evaluation (36), 42 - 61.

\section{Abstract}

To date, hardly any evidence is available on the quality of adult education programs for vulnerable adults. Evaluation instruments or models mostly focussed on regular education and less on programs of adult education aiming to enhance social inclusion. This study presents a first exploration of the construct validity of a newly developed instrument, called the SIT-instrument (Social Inclusion after Transfer) for the evaluation of educational programs for vulnerable adults and their impact on increasing social inclusion. The sample consisted of 308 respondents belonging to the targetgroup of vulnerable adults. The results of the validation study indicate a reliable instrument consisting of elements of a learning environment for "vulnerable" adults influencing 4 specified categories of social inclusion. 


\section{Background}

Despite the significant attention for Life Long Learning in Europe, evaluation studies of educational programs aiming to enhance social inclusion of vulnerable adults are very scarce. However, given the socio-economic developments in Western countries, the group of vulnerable adults without job perspectives is growing (Nickell, Nunziata and Ochel, 2005). The group of vulnerable adults consists of senior people, adults experiencing social or economical problems in daily life, physically or mentally handicapped persons or immigrants having language problems. For this group of vulnerable adults, educational programs are organised aiming at enhancing the social inclusion of the participants, this means increasing their socio-economic standard of daily life.

The targetgroup of vulnerable adults has specific features. First, they are not easily fitting in regular schooling systems, as many of them have negative prior school experiences. The participants aim to reach personal goals to improve daily life instead of gaining a diploma as an entrance ticket to the labour market. Most adult learners, defined as "vulnerable", join training courses, because they need assistance in daily life, for example in writing their own language, having a good conversation, using a cell phone or personal computer, solving problems or making important choices in their personal life or organising their financial administration. Regarding Jarvis and Griffin (2003) for "vulnerable adults" education is a lifelong process aiming at increasing quality of life. This implies the outcomes of these programs are not defined in terms of cognitive learning gains or employment, but in terms of social inclusion. Accordingly McClusky (1970) and Serrano-García and Bond (1994) learning aims to decrease the marginalisation and furthermore to empower the vulnerable adults. Second, the target group is very heterogeneous in learning needs with several backgrounds and levels of education (Labouvie and Baltes, 1973). Despite group based programs, institutes of adult education have to fulfil the specific need of each individual learner, showing a wide diversity of goals per learner.

In order to capture the specific features of the targetgroup and the adult education programs they are participating in, it can be expected that the regular evaluation instruments of educational programs, mostly developed for regular education programs in primary, secondary and higher education, are not adequate. Questions arise such as: How to measure outcomes of adult education programs when social inclusion is aimed for instead of cognitive performance and employment? Given the context of adult education for social inclusion, which aspects of the learning environment are relevant to evaluate? To date, hardly any evidence is available on the quality of adult education programs for vulnerable adults. Regarding Partridge (1999) on the Fifth International Conference on Adult Education in Hamburg in 1997 it became clear that specified input for improvement of adult education programs is needed. According to Partridge (1999) a framework for evaluation is needed to get insights in the possibilities for diversification of useful adult education programs. By this Partridge (1999) meant insights in most important elements of learning 
environments, which influence the increase of social inclusion by adult learners (as an effect of the learning process).

In this study, we present the results of the development and validation of an evaluation instrument for education programs aiming for the enhancement of social inclusion of vulnerable adults. Because for this targetgroup, the application of the competencies learned during the programs in their daily life is of utmost importance, we take the theoretical perspective of transfer of training as developed in studies in Human Resource Development (HRD) literature.

\section{The issue of transfer in adult education programs for social inclusion}

During the past twenty years, a lot of studies have been conducted in the field of HRD in order to better understand how various variables influence the extent to which trainees transfer what they have learned during the training programs to their daily life, more specifically the workplace. Many studies on transfer of training are based upon the transfer model of Baldwin and Ford (1988) and discern mainly three groups of variables influencing transfer of training: the learner, the design of the training program and the work environment where the newly acquired competencies have to be applied. These three groups of variables have been addressed in many studies and based on the results, refinements of the model have been proposed (e.g. Holton, Chen and Naquin, 2003). Although a lot of research has been conducted, hardly any attention has been paid to programs for vulnerable adults instead of for high skilled employees. Moreover, most programs under study aimed for professional development of the trainees and not for personal development in terms of social inclusion. Given the targetgroup of vulnerable adults participating in educational programs for social inclusion, the environment and more precisely the life-circumstances of the learner can either improve or block the transfer. In addition, given the vulnerability of the targetgroup, it can be expected that the specific life-circumstances of the participants will influence the extent of transfer probably in a more significant way than in the programs traditionally measured in transfer-of-training studies. Moreover, the extent to which the learning environment (design) matches the life-circumstances of the participants might play a significant role in the transfer process.

One interesting and relevant study is conducted by Nijman (2004). He studied the issue of transfer for vulnerable adults, in terms of low skilled employees. Based on the aforementioned earlier models of transfer of training, Nijman (2004) include 6 factors influencing transfer of training among lower educated adults. The factors involved, are: personality characteristics (1), motivation (2), supervisor support (3), transfer climate (4), transfer design (5) general work environment and (6) elements of the learning environment. Although the Nijman study (2004) addresses low skilled adults and is therefore of specific relevance, it is directed towards training for the workplace and does not examine the 
educational programs aiming to enhance social inclusion. Therefore, several modifications have to be made. Firstly Nijman (2004) studied the transfer of learning enhancing jobrelated skills and behaviour. Adult education programs enhancing social inclusion prepare learners on functioning in daily life. Consequently the factor general work environment as studied by Nijman (2004) refers in our context to the daily life environment and barriers or support for transfer experienced there. In addition, especially in our targetgroup, lifecircumstances such as health, happiness and safety feelings influence social inclusion of the vulnerable adults participating in the programs under study (Andrews and Withey, 1974). Therefore the life-circumstances as discerned in the study of Andrews and Withey (1974) bridge the gap of Nijmans (2004) job-related model to programs aimed for enhancing social inclusion.

Secondly, Nijman (2004) stresses the importance of support by the supervisor at work. In the specific context of this study, the teachers of the program fulfil to a large extent the role of supervisor in terms of trainer or coach.

Thirdly, the design of the training program as defined by Nijman (2004) is mainly based upon the features of conventional professional training programs grounded in behaviourist and cognitivist learning theories. Current training programs and more specifically the educational programs addressed in this study are inspired by constructivist learning theories, stressing the importance of interaction, looking from multiple perspectives to a subject and relating theory to practice by using authentic learning materials (Van Lakerveld, Van den Berg, De Brabander et al., 2000; Baldwin and Ford, 1988; Holton, Chen and Naquin, 2003; Van der Vlerk, 2005; Simons and Bolhuis, 2004; Nijhuis, Segers and Gijselaers, 2005; Tenenbaum et al. 2001; Thijssen, 2001). Therefore, in order to measure the design of the learning environment in the educational programs, we included these design characteristics. Fourth, regarding the specific features of the targetgroup "vulnerable adults" the defined personality characteristics of Nijman (2004) seem to lack the aspect of self-direction. A study on low educated employees of Raemdonck (2006) points out that self-direction in learning can have an impact on the outcome of learning of vulnerable adults (as a targetgroup of adult education). Therefore, given the targetgroup, we address self-direction in learning as a relevant individual input variable of the participants.

\section{Towards the evaluation of adult educational programs for social inclusion}

Based upon prior research on transfer of training, more specifically the model of Nijman (2004) and taking into account the specific features of the targetgroup and educational programs in this study, we address the following variables: (1) as input measures: the background characteristics and motivation of the participants and the extent of self-directed learning; (2) as process measures we focus on the transfer design, including teacher support, learning contents and -activities, transfer climate and on the participants' life- 
circumstances; (3) as output measures we include two social inclusion variables namely activation and internalisation on the one hand and participation and connection on the other hand.

3.1 Input measures: Trainee characteristics: Background characteristics, motivation and selfdirected learning

\subsubsection{Background characteristics and motivation of the participants}

Researchers as Baldwin and Ford (1988) and Holton, Chen and Naquin (2003) describe the trainee as an independent personality with his or her own motivation during learning. Likewise Pugh and Bergin (2006) argue that motivational factors indeed seem to have a significant impact on transfer, because of their influence on cognitive engagement relating transfer of training. Furthermore Noe and Schmitt (1986) discuss the distinction between extrinsic and intrinsic motivation influencing the training results. Regarding the targetgroup vulnerable adults the intrinsic motivation can be seen as a voluntary participation in training differentiating the extrinsic motivation seen as mandatory participation. Besides the motivational aspect Verté et al. (2007) argued that few characteristics are determined per trainee with possible influence on social inclusion, to mention age, gender, number of children, marital status, level of schooling, prior diplomas and courses, (un)employment and racial background.

\subsubsection{Self-directed learning}

Besides the trainees' background characteristics and their motivation to participate, former research on adult learning (low skilled employees) indicated the importance of self-directed learning (Raemdonck, 2006; Knowles, 1975; McGivney, 1992; Ryan and Deci, 2000). Of specific relevance is the study of Raemdonck (2006). She explored the role of self-directed learning for low skilled employees to undertake learning activities at the workplace. Based on a literature review, she defined self-directed learning as "a tendency to take an active and self-starting approach to learning activities and situations and to persist in overcoming barriers and setbacks to learning" (Raemdonck et al., 2008). With this definition, she stresses the competence of learners to influence their own learning process taking the individual characteristics as well as conditions of the surroundings into account. In order to evidence the role of self-directed learning with low skilled employees, she developed two scales studying the level of self-directness in learning and career processes and the influence of contextual and individual conditions on self-directness. Regarding Raemdonck (2006) both contextual and individual factors influence the self-directness during learning. Moreover scores of self-directness among low qualified learners were high and will influence the process of learning (Raemdonck, 2006). The results of her studies indicate that increase of self-directness will be beneficiary for better results after learning by low qualified people and therefore important for the targetgroup vulnerable adults in this study. 
3.2.1 Transfer design: Learning contents and -activities, teacher support and transfer climate Baldwin and Ford (1988) underline the directive character of a transfer design by focussing on the need of specific task contents and task complexity as well as the support of a supervisor. In this respect, Tenenbaum et al. (2001) and Thijssen (2001) argue for bridging theory and practice by focussing on an interactive process of learners reflecting on their problems and implementing solutions in daily practice. Holton, Chen and Naquin (2003) stated that this interactive process should be seen as a tool to enhance transfer to daily life. Moreover, only when taking the daily life and the life-circumstances of the learner into account, the contents of learning become durable, meaningful and flexible and create an applicable learning result (Simons and Bolhuis, 2004), which is relevant for the learner (Van der Vlerk, 2005).

In line with former research on transfer of training, Nijman (2004) specifically focus on transfer climate and transfer possibilities as well as supervisory support as basic elements of the transfer design. Accordingly Nijman (2004) transfer climate and transfer possibilities reflect on the variables in the environment of the learner influencing the transfer of a course and existing of the opportunity to use new knowledge, skills and attitudes on the job, the sanctioning of transfer by others, resistance to change in the environment, both the positive and negative personal outcomes of transfer and peer support. Although Nijman (2004) refer to the working environment regarding educational programs of social inclusion for vulnerable adults the environment should be interpreted as the environment of the daily life of learners. Besides the variables mentioned by Nijman (2004) Simons and Bolhuis (2004) refer to the importance of interaction as a social process balancing between the learners' situation in the classroom and his or her external environment, based on the own life-circumstances (Andrews and Withey, 1974). Regarding Simons and Bolhuis (2004) this process is an inevitable element of the transfer climate. Accordingly educational programs aiming at social inclusion the role of the supervisor is not a job-related coach but rather a teacher guiding vulnerable adults. Regarding Nijhuis et al. (2005) it includes good teachership and a suitable assessment. This implies that supervisor support has to be seen as a management of personal flexibility (Thijssen, 2001). A teacher can fulfil different roles to increase the personal flexibility of the learner (for influencing transfer), to mention a supervisor (Holton, Chen and Naquin, 2003), a consultant (Van Lakerveld et al., 2000), a guide (Van der Vlerk, 2005) or a trainer (Simons and Bolhuis, 2004).

\subsubsection{Life-circumstances}

Regarding Andrews and Withey (1974) a person's sense of life quality can be measured by exploring social indicators. These social indicators can be used to define the improvement of social change or social inclusion of people (Andrews and Withey, 1974). However, as with the instrument presented in this article the evaluation of the specific influence of the educational programs on social inclusion is aimed for, the impact of changes in life- 
circumstances has to be controlled for. Changes in the personal life of the participants can indeed exert an important influence on their social inclusion. For example if one of the vulnerable adults gets a better job or will marry the possible decrease of social exclusion can be caused by this change instead of the participation during the training.

Besides the life quality (social indicators) of the participants, increase of social inclusion after transfer depends also on certain barriers during the learning process (McGivney, 1992). These barriers can be defined as feelings (like feeling too old for learning) or practical problems (like mobility problems) experienced by the "vulnerable" adults, that block the possibility for courses. Hence life-circumstances, the combination of the barriers during learning and the social indicators of life quality can influence the effects of training programs on social inclusion of the participants.

\subsection{Outcome measures: Social inclusion as an effect of adult education programs}

According to Main (1979) and Solarczyk-Ambrozik (1998) transfer can increase social inclusion among vulnerable adults. Moreover education will improve life-circumstances and decrease marginalisation (McClusky, 1970). Educational programs for vulnerable adults often aim to empower the trainees. Regarding Serrano-García and Bond (1994) vulnerable adults are not visible in society and need to be empowered. Although Serrano-García and Bond (1994) try to define vulnerable adults (or marginalised people) as one targetgroup, Labouvie and Baltes (1973) point out that the group exists of male and female, immigrants with several backgrounds and latter includes low educated people on different levels. Regarding Mastergeorge (2001), Guildford (2000), Fortuin and Keune (1997) and Verté et al. (2007) results of social inclusion can be defined in processes of activation, internalisation, participation and connection. Delors (1996) describes this in terms of four learning processes, namely: knowing more, doing more, being yourself or living together with others. Adult education programs for social inclusion aim to optimise the transfer of training in terms of increasing social inclusion defined as activation, internalisation, participation and connection. Concerning the programs of adult education most of them are part of a national program for social inclusion for vulnerable adults with specified criteria, ensuring the proposed goals for this kind of education.

\subsubsection{Social inclusion as process of activation and internalisation}

Guildford (2000) states that as all other adults, vulnerable adults like to be fully accepted in their families, their communities, and the society. At any rate social inclusion can be defined as a process of finding and appropriating a place in society (Guildford, 2000). According to Mastergeorge (2001) it is a process of internalisation. Vulnerable adults try to find and own their way of life in different life domains as family life, health, housing and financial affairs (including technical development), economical status, cognitive satisfaction, psycho-social 
structures, affective happiness and experience a sense of belonging to society (Andrews and Withey, 1974; Liu, 1974; Benjamin, 1994).

Despite Guildford's (2000) and Mastergeorge's (2001) argumentation internalisation is not possible for everyone. Due to organised activities vulnerable adults sometimes were just activated, but did not gain a new way of life or a new place in society (Fortuin and Keune, 1997). Regarding Fortuin and Keune (1997) on several occasions vulnerable adults gaining knowledge or improving behaviour just to manage obligations in their direct surroundings. However Fortuin and Keune (1997) state that increase of knowledge or skills without using them can be seen as a kind of activation.

\subsubsection{Social inclusion as process of participation and connection}

Besides internalisation and social inclusion Guildford (2000) points out that social inclusion can be seen as a process of taking part in society. Vulnerable adults are more likely to organise and to be involved in new forms of interaction to give a new drive to their daily life, like becoming a member of an association or taking part in neighbourhood activities.

Regarding Verté et al. (2007) elements of participation can be seen as active involvement in activities like going out, visiting official organisations or visiting activities in the own neighbourhood.

Moreover Verté et al. (2007) shows that participation does not need to be an individual process, but can be a collective process as well, where meeting and developing new social interactions is the main objective. As a possible result of participation Colley (1975), Smith (2007), Huisman et al. (2003) and Priemus (2005) define this stage of social inclusion as connection in terms of meeting and contacting other people.

In sum, the evaluation instrument validated in this study, includes the following variables: background characteristics of participants; self-directness in learning; transfer design (supervisor support, learning contents and -activities; transfer climate); life-circumstances; social inclusion as activation and internalisation; social inclusion as participation and connection.

\section{Methodology}

\subsection{Sample}

Participants ( $\mathrm{N}=308$ ) of the study are low educated adult learners following courses in the department of adult education of 10 Regional Centres of Education with 11 different locations (one of them has two separated locations). The centres of adult education are chosen at random and situated in 5 provinces of the Netherlands concentrated in the Eastern part, namely: Drenthe, Overijssel, Gelderland, Noord-Brabant and Utrecht. Table 1 gives an overview of the main characteristics of the sample of the validation study. The random 
sample was stratified according to the locations of adult education, gender and age on courses for social inclusion. Consistent with the population mean of participants in the adult education centres, the majority of the participants are female, between 61 and 80 years old, have the Dutch nationality, are married, have two kids and had 6 until 10 years of education mostly no more than secondary school or vocational education for the middle class.

Table 1: Sample characteristics: Participants' background $(\mathbf{N}=308)$

\begin{tabular}{|c|c|c|}
\hline Characteristic / category & $\mathbf{M}$ & $\%$ \\
\hline \multicolumn{3}{|l|}{ Gender } \\
\hline Male & & 24.8 \\
\hline Female & & 75.2 \\
\hline \multicolumn{3}{|l|}{ Nationality } \\
\hline Autochthonal & & 92.2 \\
\hline Foreign & & 7.8 \\
\hline Age & 57 & \\
\hline $21-40$ & & 13.4 \\
\hline $41-60$ & & 38.0 \\
\hline $61-80$ & & 46.2 \\
\hline \multicolumn{3}{|l|}{ Marital status } \\
\hline Married & & 73.4 \\
\hline Unmarried & & 20.6 \\
\hline Living together & & 6.0 \\
\hline \multicolumn{3}{|l|}{ Number of children } \\
\hline 0 & & 15.7 \\
\hline 1 & & 6.9 \\
\hline 2 & & 47.4 \\
\hline 3 & & 20.3 \\
\hline 4 & & 7.2 \\
\hline More than 4 & & 2.6 \\
\hline \multicolumn{3}{|l|}{ Total years of education } \\
\hline$<5$ & & 31.6 \\
\hline $6-10$ & & 39.9 \\
\hline $11-15$ & & 18.6 \\
\hline $16-20$ & & 8.6 \\
\hline \multicolumn{3}{|l|}{ Highest level of education } \\
\hline Primary school & & 11.2 \\
\hline Secondary school & & 34.8 \\
\hline Further education on level of middle class & & 35.5 \\
\hline Higher education & & 11.8 \\
\hline University & & 2.0 \\
\hline Other school systems & & 4.6 \\
\hline
\end{tabular}

Note: Missing values are excluded in percentage calculations.

\subsection{Procedure}

Teachers of each department of adult education received a written instruction and training by the researcher. Each department was asked to stratify 35 learners at random. The 
learners filled in a questionnaire at the beginning and the end of the educational program. The response rate was $88 \%(n=308)$. Most of the courses last 10 until 15 weeks aiming increase of social inclusion.

\subsection{Instrument development}

The SIT-instrument (Social Inclusion after Transfer) includes scales for the input, process and outcome measures (see appendix A and appendix B).

\subsubsection{Input measures}

\subsubsection{Scale 1: Background characteristics}

In the first part of the SIT social-demographic factors are included. The following factors were based on an inquiry on social inclusion of Buffel et al. (2008) for describing perspectives of specific groups in society and it's characteristics: gender, nationality, marital status, number of children, age, professional qualification, employment, motivation for joining the course.

Other factors were included as they refer specifically to the educational background and the program they participate in: highest level of education, years of education, name of regional centre for education, followed courses in earlier days, duration, name and expectation of course. These factors are based on the intake-model of the centres of adult education.

\subsubsection{Scale 2: Self-directedness in learning}

Raemdonck and Thijssen (2005) developed and validated a scale measuring self-directness in learning among low educated employees. The validation study of Raemdonck (2006) indicated this scale measures one construct. Two example items are: taking initiative for learning and continuing learning during difficulties.

\subsubsection{Process measures}

4.3.2.1 Scale 3: Transfer design: teacher support, learning contents and -activities, transfer climate

The Nijman (2004) scales supervisor support and transfer climate were adapted. The changes of these scales were the replacement of the concept working environment by the concept daily life and the replacement of supervisor by teacher. Two example items of the teacher support scale are: recognition of learners' efforts by teacher and appreciation of teacher for joining the course as a learner. Two examples of the transfer climate scale are: feedback of people by using new knowledge and skills by the learner and sceptical attitude of people towards new knowledge of skills of the learner.

For measuring learning contents and -activities, four items of the questionnaire of the translated scale of Tenenbaum et al. (2001) of Van de Watering (2006) are included. 
Example items are: reflection on topics and interaction between teacher and learners. These items refer to the methods used in the courses in order to increase transfer of learning.

\subsubsection{Scale 4: Life-circumstances}

We used the Andrews and Withey (1974) instrument measuring the life quality of American adults on 100 items. The most important items regarding life of "vulnerable adults" were used. Example items are: feeling of happiness with the own family and satisfaction of life. Four items of McGivney (1992) were added to give insights in the specific barriers for transfer to take place. Example items are: the feeling of being too old for learning and being fed up with going to school.

\subsubsection{Outcome measures}

\subsubsection{Scale 5: Social inclusion based on activation and internalisation}

The processes of social inclusion, called activation and internalisation are translated to items based on the portfolio of social competencies (Huisman et al., 2003), the catalogue of educational competencies for functioning on the labour market (Huisman and Tubbing, 2005) and for upbringing (Huisman, Kuijpers and Tubbing, 2005). Besides this an analysis of the goals of all courses for adults on the regional education centre of Nijmegen and surroundings confirmed most of these items and gave input to 13 items about communication, which completed this part of the SIT-instrument. Example items are: the competencies of using the computer and understanding things on the radio.

\subsubsection{Scale 6: Social inclusion based on participation and connection}

The items of the second scale cocnerning social inclusion is based on the validated questionnaire of Buffel et al. (2008) and the validated questionnaire of Dykstra and De JongGierveld (2006) about loneliness. Example items are: being happy with the own family and being lonely.

\subsection{Testing and refinement}

Before using the SIT-instrument a panel of 11 experts of adult education, social inclusion and educational evaluation reviewed the contents of the SIT-instrument. The panel exists of managers, civil servants, advisers and researchers all working in the field of education on local, regional and national level. They comment the SIT-instrument for its content validity and the consistency with the theoretical approaches about influences of learning environments and self-direction of learning on social inclusion. After adjustment of the used language by several items teachers of the 11 locations of adult education were asked for a critical review on the contents of each item in the SIT-instrument. Their suggestions were used to improve the clearness and unambiguousness of the statements used in the different items. Based on their comments some of the items were rephrased. The most important 
comment was that it is not possible for low educated people to give a self-reflective judgement on a negative formulated statement. Most of these statements were rephrased.

\subsection{Method of analysis}

In order to develop an evaluation instrument, which is feasible to use in education programs for vulnerable adults, the purpose of the analyses is to reduce the information in most of the variables into a set of weighted linear combinations of those variables. Therefore we used Principle Components Analysis (PCA).

For the self-directed Learning scale of Raemdonck (2006), which has been validated in with low skilled employees in the context of employability, our purpose is to identify the latent variables, which are contributing to the common variance in the measured variables. Therefore we use Factor Analysis (FA) with the maximum likelihood extraction procedure, which will attempt to exclude unique variance from the analysis. The PCA and FA were conducted by using SPSS 15.0 .

In addition correlation analyses were conducted to measure the association between the scales measuring process measures on the one hand and those measuring outcome measures on the other hand. In addition, correlations were measured between the factors and their corresponding constructs.

\section{Results}

\subsection{Towards an empirical based structure of the SIT-instrument}

For each scale a Principal Component Analysis with a Direct Oblimin Rotation and a Maximum Convergence of .99 was used to give insights in the possible dependence of the items. The Kaiser-Meyer-Olkin measure of sampling adequacy can considered to be good (Hutcheson and Sofroniou, 1999) for each scale (self-directed learning: 0.914; transfer design: 0.745 ; life-circumstances: 0.861 ; social inclusion activation and internalisation: 0.869 and social inclusion participation and connection: 0.820). Also the Barlett's test of sphericity was significant $(p<0.001)$. Taken together, these tests provide a minimum standard which should be passed before a principal components analysis should be conducted.

The number of factors per scale is determined based on an inspection of the own values and the scree-plots. Following a discriminate effect of the items (items scoring lower than 0.30 or higher than 1.00 on a 1-10 scale) several items were removed. Besides the items loading on more than one component were removed also. Table 2 presents for each scale the resulting factors and table 5 the factorloadings. The maximum likelihood factor analysis of the scale "self-directed learning" resulted in one factor with a Cronbach's Alpha of 0.899, a very good Kaiser-Meyer-Olkin measure of sampling adequacy (0.908) and a significant Barlett's test of 
sphericity $(p<0.001)$. Regarding table 2 the results of the PCA on the "transfer design", show 4 factors: support teacher (1), learning contents and -activities (2), direct surroundings (3) and transfer possibilities (4). For the scale "life-circumstances", the PCA shows also 4 factors namely: personal life-circumstances (1), barriers (2), direct surroundings (3) and care (see table 2). 


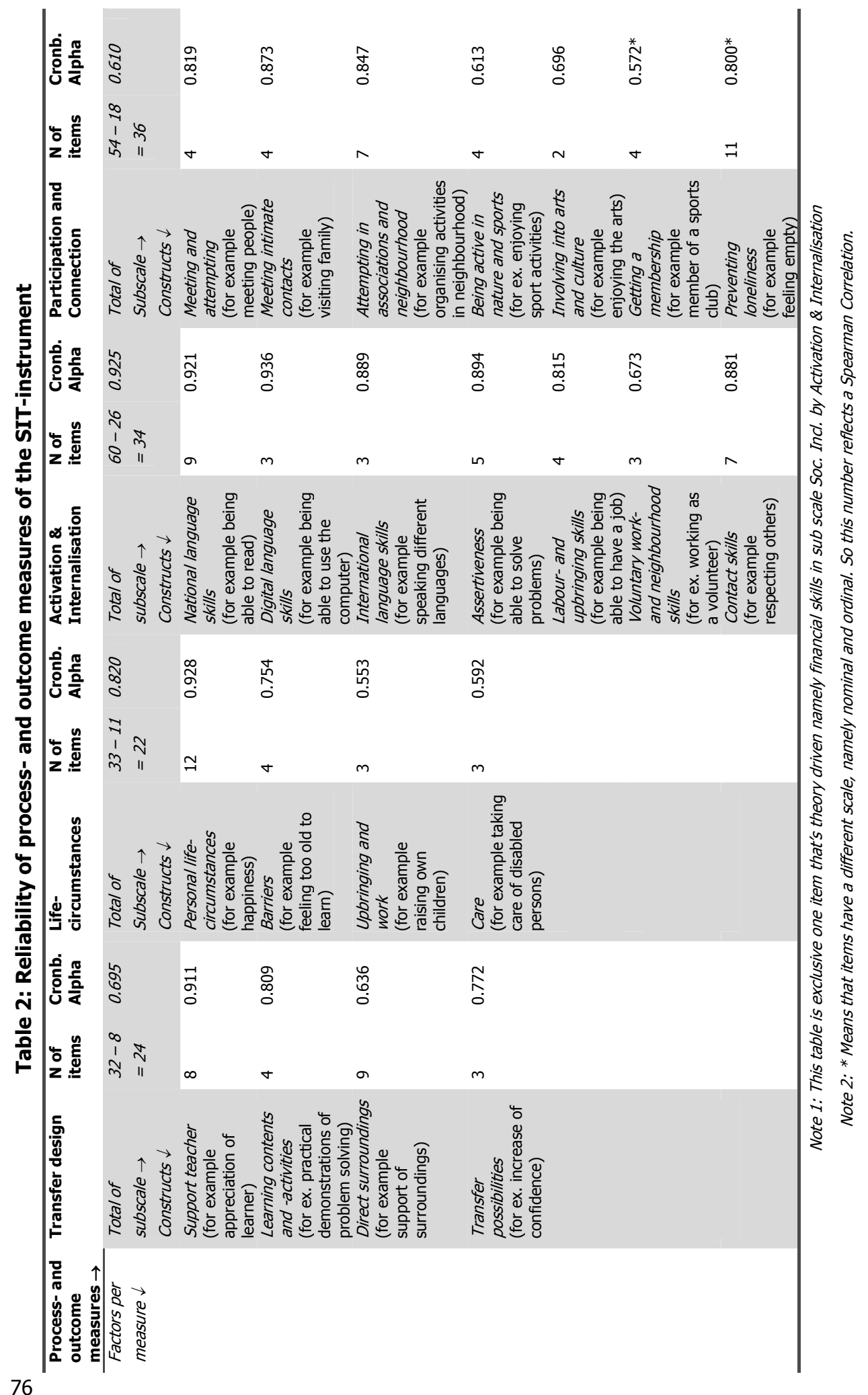


With respect to the two social inclusion scales, the PCA indicates for "Activation and Internalisation" 7 factors: national language skills (1), digital language skills (2), international language skills (3), assertiveness (4), labour- and upbringing skills (5), voluntary work- and neighbourhood skills (6) and contact skills (7) (see table 2). Regarding table 2 for "Participation and Connection" the PCA indicates also 7 factors: meeting and attempting (1), Meeting intimate contacts (2), attempting in associations in neighbourhood (3), being active in nature and sports (4), involving into arts and culture (5), getting a membership (6) and preventing loneliness (7). The PCA for the scale of "Self-directed learning" shows just 1 factor called self-directness. Therefore it is not part of table 2 .

With respect to the reliability of the scales, most of them are acceptable, except for the scales "upbringing and work" and "care". Theory driven the decision is made to remain the two constructs in the SIT-instrument, because of its necessity, considering research of Andrews and Withey (1974) convinced by the surplus value of the measurement of these two items, because upbringing, work and care are three important elements for ones structure of the day with a possibility to block one's own development. The Cronbach's Alphas of both scales life-circumstances (0.820) and transfer design (0.695) are acceptably high (see table 2).

Both scales of social inclusion are also considered to be reliable: 0.925 for "Activation and Internalisation" and 0.610 for "Participation and Connection" (see table 2). The scales of social inclusion distinguished 7 constructs after the factor analysis. For each construct Cronbach's Alpha is to mention as high enough. Two exceptions for the analysing technique are made by the constructs "getting a membership" and preventing loneliness". The two constructs do not have a Likert-scale 1-10, but a nominal scale (for "getting a membership") and an ordinal scale (for "preventing loneliness"). The scores in table 2 show the scores of a Spearman correlation. With a correlation of 0.572 the construct of "getting a membership" isn't very reliable, but is still in the scale by again a theory driven consideration (Verté et al., 2007).

One item ("financial handiness") without any high loading on one of the constructs of social inclusion is not removed from the scale, because of its worthy information for the involved "schools". One of the goals of the courses is the improvement of the financial handiness of learners. That is why the item still takes part of the scale.

\subsection{Internal validity for the instrument and its process- and outcome measures}

Regarding an internal validity of the instrument and its scales the construct validity is defined by determination of the Pearson's Correlation between the scales belonging to the processand outcome measures.

First of all the correlation between the scales referring to the process (process measures: transfer design: 0.827 and life-circumstances: 0.746 ) on the one hand and to the outcomes 
(activation and internalisation: 0.871 and participation and connection: 0775 ) of the programs on the other hand are satisfactory (see table 3 ).

Table 3: Correlation between scales of the process- and outcome-measures of the SIT-instrument

\begin{tabular}{|c|c|c|}
\hline Basic scales $\rightarrow$ & \multirow[t]{2}{*}{ Training design $(N=177)$} & \multirow[t]{2}{*}{ Social Inclusion $(N=308)$} \\
\hline Process- and outcome me & & \\
\hline Transfer design & $0.827 * *$ & - \\
\hline Life-circumstances & $0.746 * *$ & - \\
\hline Activation \& Internalisation & - & $0.871 * *$ \\
\hline Participation and Connection & - & $0.775^{* *}$ \\
\hline
\end{tabular}

Note 1: **Correlation is significant at the 0,01 level (2-tailed)

Note 2: * Correlation is significant at the 0,05 level (1-tailed)

Regarding the correlation analysis most of the factors in table 4 indicate a high correlation ( 0.5 and higher) as well as a high loadings for the different items per factor (see table 5). Few of them are lower than 0.5 . We did not remove these factors from the instrument based on theoretical arguments, for example the factor direct surroundings belonging to Nijman's scale (2004) (and according to Nijman (2004) inevitable for the evaluation of the outcome of courses) and the factors voluntary work- and neighbourhood skills and meeting intimate contacts belonging to the scale of Verté et al. (2007). Regarding Verté et al. (2007) these specified constructs are important to analyse the four processes of social inclusion, because voluntary work and neighbourhood skills and meeting intimate contacts are inevitable elements in having the feeling of belonging to the society and a feeling of happiness. The correlations of the last two factors of the scale "Participation and Connection" are defined in Spearman's Rho. A negative relation is shown, because of its contents. If a learner obtains a high score on these two scales it means a lower indication for social inclusion on participation and connection. 


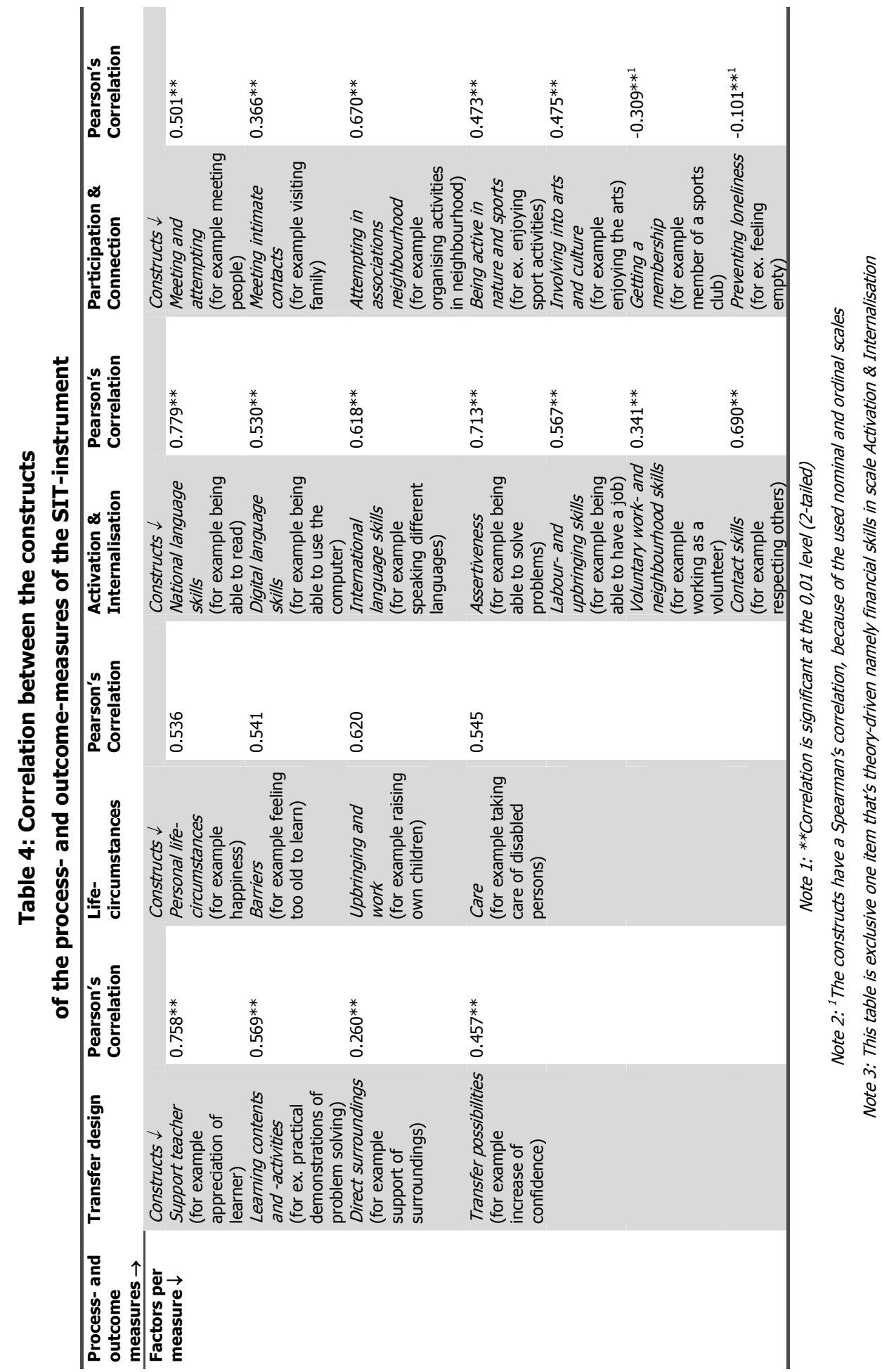




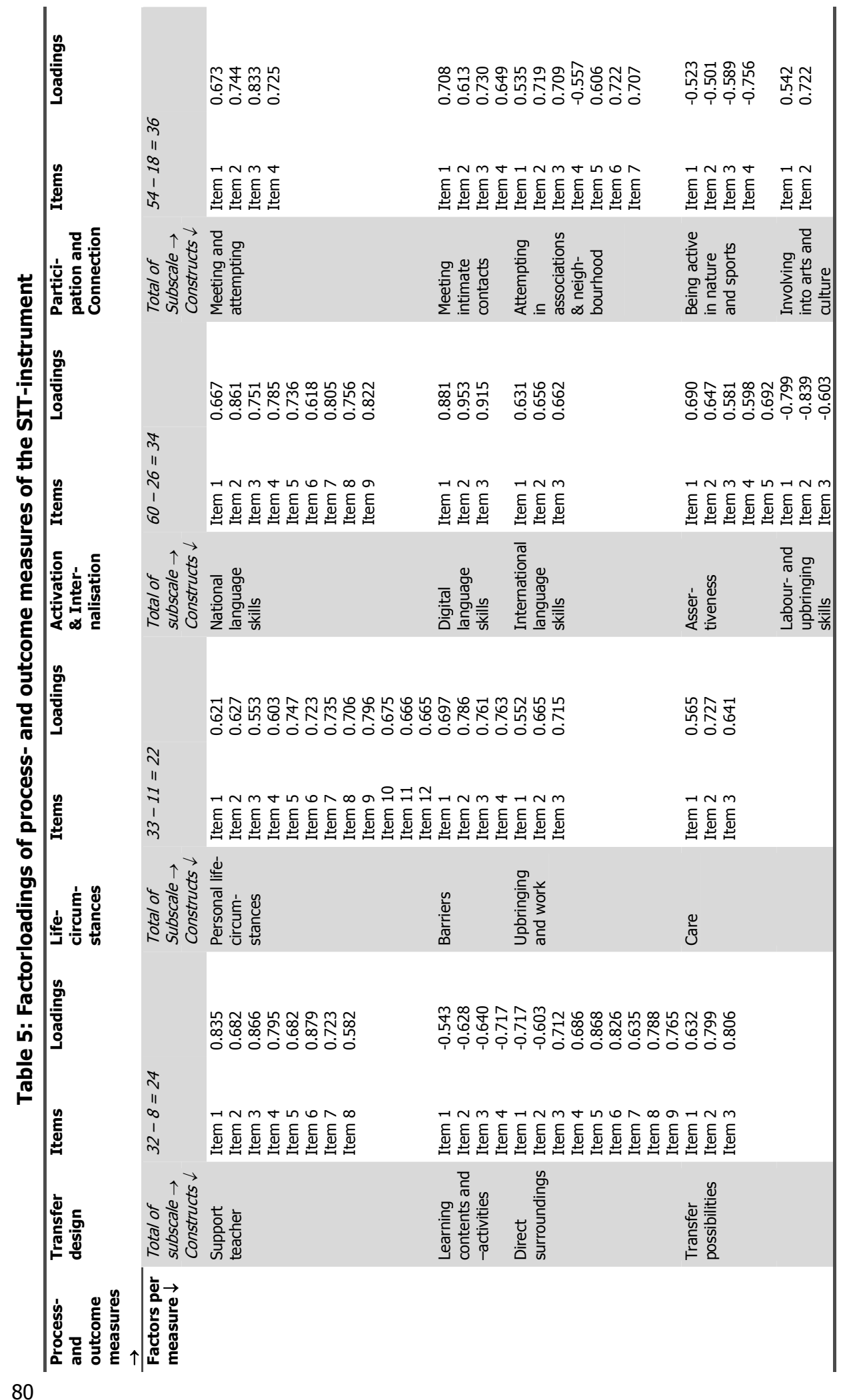




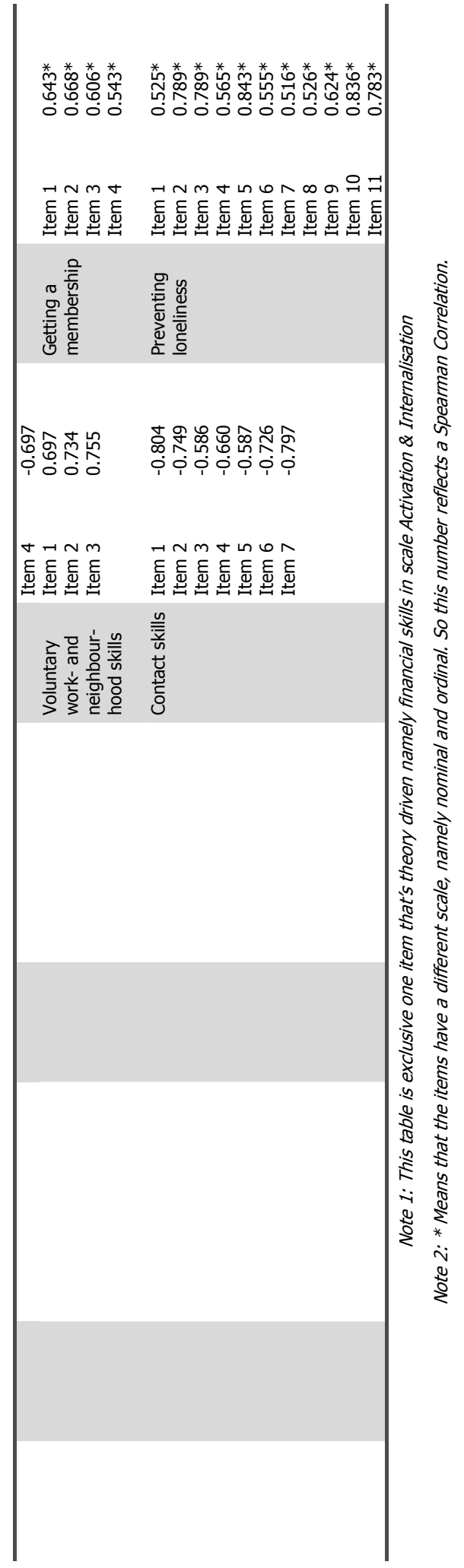




\section{Conclusions and discussion}

This study aims to validate an instrument for evaluation of educational programs for vulnerable groups (especially adults). Results of this study include two elementary findings. First of all the study provided a reliable instrument for providers of adult education, consisting of three parts: (a) participants' characteristics; (b) training design characteristics and (c) social inclusion measures. The development of the scale was based on the use of validated scales of researchers in the field of transfer of training and of social inclusion (Verté et al., 2007; Nijman, 2004; Van de Watering, 2006; Andrews and Withey, 1974; McGivney, 1992; De Jong-Gierveld and Van Tilburg, 2008; Raemdonck, 2006) combined with theory driven elements for some items of social inclusion (Huisman et al., 2003; Huisman and Tubbing, 2005; Huisman, Kuijpers and Tubbing, 2005) and input after a case study in one of the research locations. These validated instruments and a theory driven approach provided a foundation for the SIT. Regarding the Cronbach's Alpha (see table 2) its reliability is high enough. The results of the validation study indicated the SIT-instrument as a reliable instrument for the evaluation of training courses for vulnerable adults (for the 5 sub scales $\alpha$ $=0.820,0.695,0.925,0.610$ and 0.899 ).

Secondly the SIT-instrument can be used to underline the influence of the training elements of the training courses on the improvement of social inclusion. In the SIT-instrument different factors influencing transfer of training in terms of social inclusion are included. The influence and barriers of the different transfer climate of each learner and the self-directness of the learner (difficult to influence by "schools") can differ per person and explain that some learners learn faster than others on the same circumstances in a training design. Therefore these elements form two essential parts of the SIT-instrument. In this way, the SITinstrument can be used as an evaluation tool to determine the influence of the learning environment on the increase of social inclusion of the learners.

Despite this we urge researchers to take care of a cautious interpretation of the results of part 5 of the SIT-instrument, involving the processes of participation and connection of social inclusion. The scale of the last two constructs of this sub scale ("getting a membership" and "preventing loneliness") are namely based on a nominal and ordinal scale and not on a Likert-scale of 10 elements (used by the other constructs).

This study is conducted in the context of Dutch adult education programs. Although the programs are representative for the Dutch situation, future research is needed to confirm the construct validity of the instrument. First follow up research should increase sample size. Based on large sample size including a large number of participants per group (e.g. employed versus unemployed participants, different ethnical background of participants; age groups), per training centre and per region, will give the opportunity to measure the stability of the instrument across different groups of participants, training centres and regions. 
Moreover, cross validation in different countries is an essential next step. Currently, a project is ongoing aimed to validate the instrument in different European countries. This cross national construct validation is a first step in developing comparable data with respect to the effects of adult education programs on social inclusion. According to the Fifth International Conference on Adult Education in Hamburg in 1997 it became clear that specified input for improvement of adult education programs is needed (Partridge, 1999). By exploring the effects of adult education influenced by the most important elements of learning environments one gets insights in the possibilities for diversification of useful adult education programs. Consequently this means investment in lifelong learning and in people defined as one of the key areas of the Lisbon Strategy of the EU.

As a next step after this first exploration of the construct validity of the instrument, a feasibility study needed to confirm the value of this instrument as an evaluation tool for adult education programs for social inclusion. Questions about when and how to administer this instrument have to be dealt with, taking into account time needed for participants to answer all items.

Moreover, in-depth studies using qualitative research methods can highlight how the targetgroup experiences the influence of input and process measures on their social inclusion. Regarding Tan (2008) the phenomenography is one relevant method to analyse the variation of the experienced phenomena (in this case the increase of social inclusion influenced by the training design).

Finally, the respondents for the SIT-instrument are more than only the participants, the targetgroup of vulnerable adults. Although their perceptions and experiences are of high value, the validity of the results can be enhanced by including the perceptions of the teachers. On the one hand, if perspectives of the involved teachers differ from the participants, this is an interesting starting point for reflection and discussion. On the other hand, self-reports of students have often be evidenced as being not reliable. Phenomena such as over- and underrating have been evidenced before. Therefore, using information from various sources enhances the validity of the interpretation of the results.

The SIT-instrument can be used for monitoring purposes. The information provided by the instrument makes it possible not only to monitor in general if the educational program is effective in terms of social inclusion, but indicates the influence of input and process factors. In this respect, the instrument offers the opportunity to specify which improvements can be made. Moreover, it can be used to monitor how fair educational programs are for different groups of vulnerable adults. In fact by using the SIT-instrument during educational programs one gets insights in the effective outcome for learners in their daily life in terms of activation, internalisation, participation and connection. As a result increase of social inclusion per learner should be clear for the learner, teacher and organisation of adult education. The SIT-instrument can be considered as an innovative evaluation tool for education, because of its focus on educational programs for vulnerable adults aiming to enhance social inclusion. Further validation of this instrument might result in a tool that, even on a 
European level, contributes to optimising the power of education to increase social inclusion of the most vulnerable adults in our societies.

\section{References}

Andrews, F. M. \& Withey, S. B. (1974). Developing measures of perceived life quality: Results from several national surveys. Social Indicators Research, 1974 (1), 26.

Baldwin, T. T. \& Ford, K. J. (1988). Transfer of training: A review and directions for future research. Personnel Psychology, 1988 (41), 43.

Benjamin, M. (1994). The quality of student life: Toward a coherent conceptualization. Social Indicators Research, 31 (3), 60.

Buffel, T., Verté, D., De Donder, L., De Witte, N. (2008). Exploring the links between conceptions of the neighbourhood and erotological research perspectives. Studies on social sciences, 2008 (1), 18.

Colley, D. G. (1975). A social change index - an objective means to discern and measure the relative current social condition of cities, towns, and their sub-communities. Social Indicators Research, 1975 (1), 26.

De Jong-Gierveld, J. \& Van Tilburg, T. (2008). De ingekorte schaal voor algemene, emotionele en sociale eenzaamheid. Tijdschrift voor Gerontologie en Geriatrie / TGG, 39 (1), 12.

Delors, J. (1996). The four pillars of education. In Jarvis, P. \& Griffin, P., Adult and Continuing Education: Major themes in education. London: Routledge, $304-313$.

Dykstra, P. A., De Jong-Gierveld (2006). Gender and Marital-History Differences in Emotional and Social Loneliness among Dutch Older Adults. Canadian Journal on ageing, 23 (2), 141.

Fortuin, K. \& Keune, C. (1997). Anders praten over jeugd: Naar een begrippenkader voor preventief jeugdbeleid. Utrecht: Verwey-Jonker Instituut.

Guildford, J. (2000). Making the case for social and economic inclusion. Canada Atlantic Region: Population and Public Health Branch.

Holton, E. F., Chen H. \& Naquin, S. S. (2003). An examination of learning transfer system characteristics across organizational settings. Human Resource Development Quarterly, vol. 14 (4), 24.

Huisman, J. \& Tubbing, M. (2005). Competentiecatalogus Educatie: Functioneren op de arbeidsmarkt. 'sHertogenbosch: CINOP.

Huisman, J., Kuijpers, C. \& Tubbing, M. (2005). Competentiecatalogus Educatie: Domein opvoeding. 'sHertogenbosch: CINOP.

Huisman, J., Pijls, T., Van Hoeij, J., Van Voorst van Beest, K., Boonaerts, Y. \& Lens, M. (2003). Portfolio sociale competenties: Primair onderwijs, vmbo, mbo. 's-Hertogenbosch: CINOP.

Hutcheson, G. \& Sofroniou, N. (1999). The multivariate social scientist. London: Sage.

Jarvis, P. \& Griffin, P. (2003). Adult and Continuing Education: Major themes in education. London: Routledge.

Knowles, M. S. (1975). Self-directed learning: A guide for learners and teachers. New York: Association Press. 
Labouvie, G. V. \& Baltes, P. B. (1973). Adolescent perception of adolescent change in personality and intelligence. Journal of Genetic Psychology, 122 (2), 17.

Liu, B. (1974). Quality of life indicators: a preliminary investigation. Social Indicators Research, 1974 (1), 22, 187 - 208.

Main, M. (1979). Social and personality-development. Contemporary Psychology, 24 (8), 11.

Mastergeorge, A. M. (2001). Guided Participation in sociocultural learning: Intervention and apprenticeship. Academic Search Premier, 22 (1), 14.

McClusky, H., Y. (1970). A dynamic approach to participation in community development. Journal of Community Development Society, 1970, 1, 8.

McGivney, V. (1992). Tracking adult learning routes: A pilot investigation into adult learners'starting points and progression to further education and training. Leicster: National Institute of Adult Continuing Education.

Nickell, S., Nunziata, L. \& Ochel, W. (2005). Unemployment in the OECD since the 1960s: What do we know? The Economic Journal, (115), 1 - 27.

Nijhuis, J. F. H., Segers, M. S. R. \& Gijselaers, W. H. (2005). Influence of redesigning a learning environment on student perceptions and learning strategies. Learning Environments Research, 2005 (8), 27.

Nijman, D.J.J.M. (2004). Supporting Transfer of Training: Effects of the Supervisor. Enschede: Universiteit Twente.

Noe, R. A., \& Schmitt, N. (1986). The influence of trainee attitudes on training effectiveness: the importance of the work environment. Journal of Applied Psychology, 80 (1), 239 - 252.

Partridge, M. (1999). Monitoring Adult Education: Monitoring adult education for knowledge-based policymaking. Hamburg: Druckerei Seemann.

Priemus, H. (2005). Het spel en de knikkers: Fysieke en sociale pijler verbonden. Tijdschrift B\&G / Uitgave Bank Nederlandse Gemeenten en Vereniging van Nederlandse Gemeenten, 2005 (1), 5.

Pugh, K. J., \& Bergin, D. A. (2006). Motivational Influences on Transfer. Educational Psychologist, 41 (3), $147-160$.

Raemdonck, I., \& Thijssen, J. (2005). Lifelong learning and employability. Lifelong Learning in Europe, 10 (2), 66 - 69.

Raemdonck, I. (2006). Self-directedness in learning and career processes: A study in lower-qualified employees in Flanders. Gent: Universiteit van Gent.

Raemdonck, I., De Grip, A., Segers, M. Thijssen, J. \& Valcke, M. (2008). Zelfsturing in leren en loopbaan als predictoren van employability bij laaggeschoolde werknemers. Gedrag en organisatie (21), 4.

Ryan, R. M. \& Deci E. L. (2000). Self-determination theory and the facilitation of intrinsic motivation, social development, and well-being. American Psychologist, vol. 55 (1), 11.

Serrano-García, I. \& Bond, M. A. (1994). Empowering the silent ranks: Introduction. American Journal of Community Psychology, 22 (4), 13.

Simons, R-J. S. \& Bolhuis, S. (2004). Constructivist learning theories and complex learning environments. In Mulder, R.H. \& Sloane, P.F.E., New approaches to vocational education in Europe. The construction of complex learning-teaching arrangements. Oxford: Symposium Books; and in Oxford Studies in Comparative Education, $13(1), 13-25$. 
Smith, M. K. (2007). Social capital. The encyclopedia of informal education, 2007. 26 - 07 - 2007. $<$ www.infed.org/biblio/social_capital.htm>.

Solarczyk-Ambrozik, E. (19). Socio-economic transformation and adult learning in Poland. In Bisovsky, G., Bourgeois, E., Bron, M., Chivers, G. \& Larsson, S., Adult learning and social participation. Wien: Verband Wiener Volksbildung, 373 - 385.

Tan, K.H.K. (2008). Qualitatively different ways of experiencing student self-assessment. Higher Education Research \& Development, vol. 27 (1), 15 - 29.

Tenenbaum, G., Naidu, S., Jegede, O. \& Austin, J. (2001). Constructivist pedagogy in conventional on campus and distance learning practice: An exploratory investigation. Learning and construction 11, 25.

Thijssen, J. (2001). Personele flexibiliteit in strategisch perspectief: De betekenis van employability voor organisatie en individu. In R. Poell \& J. Kessels, Human Resource Development, Organiseren van het leren. Alphen aan den Rijn: Samsom, 103 - 116.

Van de Watering, G. (2006). Assessment in constructivist learning environments. Maastricht: Datawyse / Universitaire Pers Maastricht.

Van der Vlerk, D. (2005). Inspireren tot leren: Het ontwerpen van een uitdagende leeromgeving. Bussum: Uitgeverij Coutinho.

Van Lakerveld, J., Van den Berg, J., De Brabander, C., \& Kessels, J. (2000). The corporate curriculum: a working-learning environment. In Proc. Annual Academy of Human Resource Development Conference: Expanding the Horizons of Human Resource Development. Raleigh-Durham NC.

Verté, D., De Witte, N. \& De Donder, L. (2007). Schaakmat of aan zet? Monitor voor lokaal ouderenbeleid in Vlaanderen. Brugge: Uitgeverij Van den Broele. 


\section{Appendix A: Table of clarification and justification of contents of SIT- instrument}

\begin{tabular}{|c|c|c|c|c|}
\hline $\begin{array}{l}\text { Scales } \\
\text { SIT-instrument }\end{array}$ & Factors measured & Source & $\begin{array}{l}\text { Nr. of } \\
\text { items }\end{array}$ & Scoring \\
\hline $\begin{array}{l}\text { Background } \\
\text { characteristics (incl. } \\
\text { motivation) }\end{array}$ & $\begin{array}{l}\text { Demographic and } \\
\text { educational } \\
\text { characteristics }\end{array}$ & $\begin{array}{l}\text { Buffel et al. (2008) } \\
\text { in combination with } \\
\text { intakelist Region. } \\
\text { Educ. Centre }\end{array}$ & 17 & $\begin{array}{l}\text { Nominal, ordinal and Likert- } \\
\text { scale rating differs per item }\end{array}$ \\
\hline $\begin{array}{l}\text { Self-directed } \\
\text { learning }\end{array}$ & $\begin{array}{l}\text { Rate of self-directness } \\
\text { in learning }\end{array}$ & $\begin{array}{l}\text { Raemdonck and } \\
\text { Thijssen (2005) }\end{array}$ & 14 & $\begin{array}{l}\text { Ordinal in categories: totally } \\
\text { agree / partly agree / not } \\
\text { agree, not disagree / partly } \\
\text { disagree / totally disagree }\end{array}$ \\
\hline Transfer design & $\begin{array}{l}\text { Teacher support, } \\
\text { transfer climate, } \\
\text { learning contents and - } \\
\text { activities }\end{array}$ & $\begin{array}{l}\text { Nijman (2004) in } \\
\text { combination with } \\
\text { Tenenbaum et al. } \\
\text { (2001) }\end{array}$ & 33 & $\begin{array}{l}\text { Likert-scale rating from } 1 \text { - } \\
10 \text { as self-reflection on } \\
\text { statements }\end{array}$ \\
\hline Life-circumstances & $\begin{array}{l}\text { Social network, attitude } \\
\text { to life, personal } \\
\text { development, locus of } \\
\text { control, pattern of } \\
\text { activities, facilities and } \\
\text { situational / } \\
\text { dispositional barriers }\end{array}$ & $\begin{array}{l}\text { Andrews \& Withey } \\
\text { (1974) in } \\
\text { combination with } \\
\text { McGivney (1992) }\end{array}$ & 31 & $\begin{array}{l}\text { Likert-scale rating from } 1 \text { - } \\
10 \text { as self-reflection on } \\
\text { statements }\end{array}$ \\
\hline $\begin{array}{l}\text { Social inclusion: } \\
\text { activation \& } \\
\text { internalisation }\end{array}$ & $\begin{array}{l}\text { Rate of activation and } \\
\text { rate of internalisation } \\
\text { (in terms of } \\
\text { competencies) }\end{array}$ & $\begin{array}{l}\text { Huisman et al. } \\
\text { (2003) in } \\
\text { combination with } \\
\text { Huisman \& Tubbing } \\
\text { (2005), Huisman et } \\
\text { al. (2005) and case } \\
\text { study Nijmegen }\end{array}$ & 60 & $\begin{array}{l}\text { Likert-scale rating from } 1 \text { - } \\
10 \text { as self-reflection on } \\
\text { statements }\end{array}$ \\
\hline \multirow[t]{3}{*}{$\begin{array}{l}\text { Social inclusion: } \\
\text { participation \& } \\
\text { connection }\end{array}$} & $\begin{array}{l}\text { A. Activities of } \\
\text { participation and rate of } \\
\text { connection }\end{array}$ & $\begin{array}{l}\text { Buffel et al. (2008) } \\
\text { in combination with } \\
\text { case study Nijmegen }\end{array}$ & 33 & $\begin{array}{l}\text { Likert-scale rating from } 1 \text { - } \\
10 \text { as self-reflection on } \\
\text { statements }\end{array}$ \\
\hline & $\begin{array}{l}\text { B. Memberships, } \\
\text { Neighbourhood } \\
\text { activities and working } \\
\text { rate }\end{array}$ & Buffel et al. (2008) & 10 & $\begin{array}{l}\text { Nominal categories: yes / } \\
\text { no }\end{array}$ \\
\hline & $\begin{array}{l}\text { C. Rate of social } \\
\text { exclusion (common, } \\
\text { emotionally and } \\
\text { socially) }\end{array}$ & $\begin{array}{l}\text { Dykstra and De } \\
\text { Jong-Gierveld } \\
(2006)\end{array}$ & 11 & $\begin{array}{l}\text { Ordinal categories: Yes / } \\
\text { partly / no }\end{array}$ \\
\hline
\end{tabular}




\section{Appendix B: Overview of scales and items of the SIT-instrument}

\section{Items scale 1: Background characteristics}

1.1 I am:

口 Male

口 Female

1.2 I have you been born:

a In < fill in country of the research>

a Not in <fill in country of the research>

1.3 My marital status at present is:

$\begin{array}{ll}\square & \text { Married } \\ \square & \text { Not married } \\ \square & \text { Living with a partner } \\ \square & \text { Widowed }\end{array}$

1.4 I have:

$\begin{array}{ll}\square & \text { No children } \\ \square & \text { One child } \\ \square & \text { Two children } \\ \square & \text { Three children } \\ \square & \text { Four children } \\ \square & \text { More than four children }\end{array}$

1.5 What age are you? (fill in your age)

口 I am .......... years old

1.6 Please tell us your highest form of education when you left school for the first time:

口 Special primary school

a Primary school

口 Special secondary school

a Secondary school

a Something like vocational school of nowadays

- Something like the high school of nowadays

口 Something like the University nowadays

口 Other: (please specify).

1.7 How long did you attend school:

口 5 years or less

ㅁ Between 6 and 10 years

口 Between 11 and 15 years

口 Between 16 and 20 years

口 Over 21 years 
a I do not have a professional qualification

1.9 I attend:

口 Courses in behalf of work

a Courses outside work

a Courses both in behalf of and outside work

a No courses

1.10 My current job status is:

口 Paid work

․ Voluntary work

口 Paid work and voluntary work

ㄱo work

1.11 I enrol on this course, because of:

口 Personal Interest (I liked it or just wanted to do it)

a An official organisation (like the community or social work) that sent me

a My employer or a colleague who sent me

- A friend, acquaintance or member of the family who encouraged me

O Other: .

1.12 What is the name of the community you live in?

1.13 What is the name of the neighbourhood you live in?

1.14 What is the name of the education centre you are attending?

1.15 What is the name of the course?

1.16 The duration of the course you are attending is . .. meetings

(Fill in number of meetings)

1.17 Why are you attending this course? (We would appreciate it if you fill this in) 


\begin{tabular}{|c|c|c|c|c|c|}
\hline Statement & $\begin{array}{l}\text { Fully } \\
\text { disagree }\end{array}$ & $\begin{array}{l}\text { Slightly } \\
\text { disagree }\end{array}$ & $\begin{array}{l}\text { Neither } \\
\text { agree nor } \\
\text { disagree }\end{array}$ & $\begin{array}{l}\text { Slightly } \\
\text { agree }\end{array}$ & $\begin{array}{l}\text { Fully } \\
\text { agree }\end{array}$ \\
\hline $\begin{array}{l}\text { 2.1 When I want to learn something new and } \\
\text { useful to me, I take the initiative }\end{array}$ & & & & & \\
\hline $\begin{array}{l}2.2 \text { I know when I need to learn something } \\
\text { new }\end{array}$ & & & & & \\
\hline $\begin{array}{l}\text { 2.3 I like to share my knowledge and skills } \\
\text { with interested and motivated people }\end{array}$ & & & & & \\
\hline $\begin{array}{l}2.4 \text { I quiz myself on my newly developed } \\
\text { skills and knowledge }\end{array}$ & & & & & \\
\hline $\begin{array}{l}\text { 2.5 The more I learn, the better I } \\
\text { understand the world around me }\end{array}$ & & & & & \\
\hline $\begin{array}{l}\text { 2.6 Over the last year I have learned lots of } \\
\text { new things on my own initiative }\end{array}$ & & & & & \\
\hline $\begin{array}{l}\text { 2.7 I am always looking for more information } \\
\text { on the subjects that interest me }\end{array}$ & & & & & \\
\hline $\begin{array}{l}2.8 \text { I will never be too old to learn new } \\
\text { things }\end{array}$ & & & & & \\
\hline $\begin{array}{l}2.9 \text { I like being involved in different } \\
\text { activities, because they offer me } \\
\text { opportunities to learn }\end{array}$ & & & & & \\
\hline 2.10 I prefer learning new things on my own & & & & & \\
\hline $\begin{array}{l}2.11 \text { I think it's important to learn new things } \\
\text { in life }\end{array}$ & & & & & \\
\hline $\begin{array}{l}\text { 2.12 I do not give up when learning } \\
\text { something new is difficult }\end{array}$ & & & & & \\
\hline $\begin{array}{l}2.13 \text { I will always find the time to learn if it is } \\
\text { something I enjoy }\end{array}$ & & & & & \\
\hline $\begin{array}{l}\text { 2.14 I know what I have to do (which steps I } \\
\text { have to undertake) if I want to learn } \\
\text { something new }\end{array}$ & & & & & \\
\hline
\end{tabular}




\section{Statement}

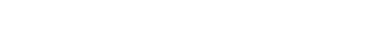

3.1 During the course, my teacher assisted me with study planning to fit in with my day to day living

3.2 During the course my teacher gave me the practical assistance I needed to successfully complete the course

3.3 I discussed with the teacher how to use my skills and knowledge in my day to day living

3.4 I discussed with the teacher the opportunities and difficulties of using my new skills and knowledge

3.5 I felt appreciated by my teacher for participating in the course

3.6 My teacher recognised the efforts I made when using my new skills and knowledge

3.7 My teacher demonstrated confidence in my ability to successfully complete the course

3.8 My teacher made it clear that they were available for any kind of help or assistance

3.9 During the course we were in constant communication with each other

3.10 During the course there were practical demonstrations of problem solving

3.11 During the course I was encouraged to reflect on topics from different perspectives

3.12 There were plenty of examples of how to use the new skills and knowledge in day to day living

\subsection{A Since you have completed the course, what new skills or knowledge have you gained?}

(Mention at most 3 things)

2

3.12.B Since you completed the course, is there anything that you have more confidence in and are doing more of now? (Mention at most 3 things)

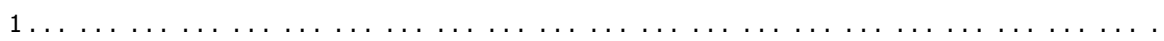

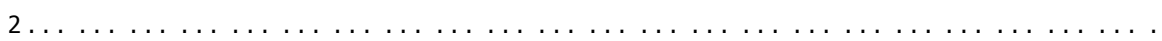

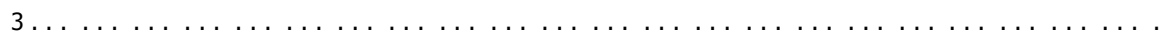




\begin{tabular}{|c|c|c|c|c|c|c|c|c|c|c|c|}
\hline \multicolumn{2}{|c|}{ Statement } & 1 & 2 & 3 & 4 & 5 & 6 & 7 & 8 & 9 & 10 \\
\hline & & 1 & 2 & 3 & 4 & 5 & 6 & 7 & 8 & $s$ & 10 \\
\hline 3.13 & $\begin{array}{l}\text { Since completing the course I find it hard to get the things } \\
\text { needed for using my new skills or knowledge in my day to } \\
\text { day living }\end{array}$ & & & & & & & & & & \\
\hline 3.14 & $\begin{array}{l}\text { Since completing the course people around me cannot see } \\
\text { me use my new skills or knowledge }\end{array}$ & & & & & & & & & & \\
\hline 3.15 & $\begin{array}{l}\text { Since completing the course people around me do not like } \\
\text { to see me use my new skills or knowledge }\end{array}$ & & & & & & & & & & \\
\hline 3.16 & $\begin{array}{l}\text { In general people around me are sceptical about new } \\
\text { knowledge or skills gained by joining courses }\end{array}$ & & & & & & & & & & \\
\hline 3.17 & $\begin{array}{l}\text { Since completing the course people around me do not care } \\
\text { if I use my new skills or knowledge }\end{array}$ & & & & & & & & & & \\
\hline 3.18 & $\begin{array}{l}\text { Since completing the course I get negative feedback if I do } \\
\text { not use my new skills or knowledge in work }\end{array}$ & & & & & & & & & & \\
\hline 3.19 & $\begin{array}{l}\text { Since completing the course people around me notice } \\
\text { when I do not use my new skills or knowledge }\end{array}$ & & & & & & & & & & \\
\hline 3.201 & $\begin{array}{l}\text { In general I would like to have had more support and help } \\
\text { from people around me during my course }\end{array}$ & & & & & & & & & & \\
\hline 3.21 & $\begin{array}{l}\text { In general I would like to have had more support and help } \\
\text { from people around me when I use my new skills or } \\
\text { knowledge }\end{array}$ & & & & & & & & & & \\
\hline & & 1 & 2 & 3 & 4 & 5 & 6 & 7 & 8 & 5 & 10 \\
\hline 3.22 & $\begin{array}{l}\text { Since completing the course people around me think } \\
\text { joining a course is very worthy }\end{array}$ & & & & & & & & & & \\
\hline 3.23 & The course has given me new found freedom & & & & & & & & & & \\
\hline 3.24 & $\begin{array}{l}\text { The course has given me a kind of self-determination in } \\
\text { my life }\end{array}$ & & & & & & & & & & \\
\hline
\end{tabular}




\begin{tabular}{|c|c|c|c|c|c|c|c|c|c|c|}
\hline Statement & 1 & 2 & 3 & 4 & 5 & 6 & 7 & 8 & 9 & 10 \\
\hline & 1 & 2 & 3 & 4 & 5 & 6 & 7 & 8 & 9 & 10 \\
\hline 4.1 I am happy with my family life & & & & & & & & & & \\
\hline 4.2 I am in good health & & & & & & & & & & \\
\hline 4.3 I feel responsible & & & & & & & & & & \\
\hline 4.4 I can change the things around me that I do not like & & & & & & & & & & \\
\hline $\begin{array}{l}\text { 4.5 I can deal with problems and situations that occur in my } \\
\text { life }\end{array}$ & & & & & & & & & & \\
\hline 4.6 I am happy being myself & & & & & & & & & & \\
\hline 4.7 I am happy with how I use my free time & & & & & & & & & & \\
\hline 4.8 My life is challenging & & & & & & & & & & \\
\hline 4.9 My life is full of variety & & & & & & & & & & \\
\hline 4.10 I am financially secure & & & & & & & & & & \\
\hline 4.11 I feel safe living in my neighbourhood & & & & & & & & & & \\
\hline 4.12 During my spare time I can engage in outdoor activities & & & & & & & & & & \\
\hline & 1 & 2 & 3 & 4 & 5 & 6 & 7 & 8 & 9 & 10 \\
\hline 4.13 I have a successful career & & & & & & & & & & \\
\hline $\begin{array}{l}4.14 \text { I have a secure job and wages and good working } \\
\text { conditions }\end{array}$ & & & & & & & & & & \\
\hline 4.15 I have good parenting skills & & & & & & & & & & \\
\hline & 1 & 2 & 3 & 4 & 5 & 6 & 7 & 8 & 9 & 10 \\
\hline 4.16 Due to my religion I am happy with my life & & & & & & & & & & \\
\hline 4.17 I am doing things to help individuals or groups in society & & & & & & & & & & \\
\hline $\begin{array}{l}4.18 \text { I take care of / look after a sick person, a disabled person, } \\
\text { an older member of the family, friend, acquaintance or } \\
\text { neighbour }\end{array}$ & & & & & & & & & & \\
\hline & 1 & 2 & 3 & 4 & 5 & 6 & 7 & 8 & 9 & 10 \\
\hline 4.19 There is a lack of transport for me & & & & & & & & & & \\
\hline 4.20 I am too old to learn & & & & & & & & & & \\
\hline $\begin{array}{l}\text { 4.21 I have no self-confidence, as my earlier years in school } \\
\text { were difficult }\end{array}$ & & & & & & & & & & \\
\hline 4.22 I am fed up being at school and in the classroom & & & & & & & & & & \\
\hline
\end{tabular}


Scale 5: Social inclusion based on activation and internalisation

\section{Statement}

\section{\begin{tabular}{ll|l|l|ll|l|ll|l|}
1 & 2 & 3 & 4 & 5 & 6 & 7 & 8 & 9 & 10
\end{tabular}}

5.1. I can say what I mean

5.2. I can write in <fill in name of the language>

5.3. I have good listening skills

5.4. I have good speaking skills

5.5. I have good writing skills

5.6. I am cooperative

5.7. I can understand things that I see on TV

5.8. I can understand things that I hear on the radio

5.9. I can read the paper, a book or something else

5.10. I can use the computer

5.11. I can use the internet

5.12. I can communicate with other people via the internet

5.13. I can understand people who do not live in < fill in name of country>

5.14. I can speak another language as well as < fill in name of language >

5.15. I can write in another language as well as < fill in name of language>

5.16. I am self-confident

5.17. I am assertive

5.18. I can manage and resolve conflicts

5.19. I have good problem solving skills

5.20. I am a confident decision maker

5.21. I have a good understanding of parenting of my own children

5.22. I have good parenting skills for raising my children

5.23. I am good at my job

5.24. I have a good relationship with the school / childcare that my children attend

5.25. I can work hard / good in my voluntary (work) capacity

5.26. I am involved in making decisions that affect my neighbourhood

5.27. I am involved in organising events in my neighbourhood

5.28. I have good living conditions in my neighbourhood

5.29. I am helpful to others

5.30. I have strong relationships with important organisations

5.31. I respect others

5.32. I have lots of friends

5.33. I am kind and polite to others

5.34. I know lots of people in a nice way

5.35. I manage my own finances 


\begin{tabular}{|c|c|c|c|c|c|c|c|c|c|c|}
\hline Statement & 1 & 2 & 3 & 4 & 5 & 6 & 7 & 8 & 9 & 10 \\
\hline & 1 & 2 & 3 & 4 & 5 & 6 & 7 & 8 & 9 & 10 \\
\hline I take part in outdoor activities & & & & & & & & & & \\
\hline 6.2 I meet plenty of people & & & & & & & & & & \\
\hline 6.3 I build on the contacts I make with new people & & & & & & & & & & \\
\hline 6.4 I enjoy making new friends & & & & & & & & & & \\
\hline & 1 & 2 & 3 & 4 & 5 & 6 & 7 & 8 & 9 & 10 \\
\hline I often visit my family & & & & & & & & & & \\
\hline 6.6 I often visit friends and acquaintances & & & & & & & & & & \\
\hline 6.7 I am happy with the relationship I have with my family & & & & & & & & & & \\
\hline $\begin{array}{l}\text { 6.8 I am happy with the relationship I have with friends and } \\
\text { acquaintances }\end{array}$ & & & & & & & & & & \\
\hline & 1 & 2 & 3 & 4 & 5 & 6 & 7 & 8 & 9 & 10 \\
\hline 6.9 I organise activities in my neighbourhood & & & & & & & & & & \\
\hline $\begin{array}{l}\text { 6.10 I organise events and activities for an association of which } \\
\text { I am member }\end{array}$ & & & & & & & & & & \\
\hline $6.11 \mathrm{I}$ advise other people about the things that interest me & & & & & & & & & & \\
\hline $\begin{array}{l}\text { 6.12 I take part in events and activities held in the community } \\
\text { centre }\end{array}$ & & & & & & & & & & \\
\hline 6.13 I organise events and activities in the community centre & & & & & & & & & & \\
\hline $\begin{array}{l}\text { 6.14 I am a member of a board: for example the board of an } \\
\text { association }\end{array}$ & & & & & & & & & & \\
\hline $\begin{array}{l}6.15 \text { I am a member of an association that represents the } \\
\text { interests of a particular group for example: elderly, } \\
\text { disabled people, etc. }\end{array}$ & & & & & & & & & & \\
\hline & 1 & 2 & 3 & 4 & 5 & 6 & 7 & 8 & 9 & 10 \\
\hline $6.16 \mathrm{I}$ join going outdoors (in nature) & & & & & & & & & & \\
\hline 6.17 I do (some) gardening & & & & & & & & & & \\
\hline $6.18 \mathrm{I}$ take part in regular exercise & & & & & & & & & & \\
\hline 6.19 I join sporting activities & & & & & & & & & & \\
\hline & 1 & 2 & 3 & 4 & 5 & 6 & 7 & 8 & 9 & 10 \\
\hline $\begin{array}{l}\text { 6.20 I'm joining activities of the arts (theatre, art, movies, } \\
\text { music, dancing and singing) }\end{array}$ & & & & & & & & & & \\
\hline $\begin{array}{l}\text { 6.21 I visit cultural venues (theatre, art, movies, music, dancing } \\
\text { and singing) }\end{array}$ & & & & & & & & & & \\
\hline
\end{tabular}

\section{Statement}

\section{Yes}

6.22 I take part in activities in my community

6.23 I am a member of an association / group

6.24 I am a member of a sports club

6.25 I am a member of <fill in local cultural association> 


\begin{tabular}{|c|c|c|c|}
\hline Statement & Yes & $\begin{array}{l}\text { More or } \\
\text { less }\end{array}$ & No \\
\hline 6.26 I always have someone close to me to share & & & \\
\hline 6.27 I do not have close friends & & & \\
\hline 6.28 I feel empty & & & \\
\hline 6.29 I have people to rely on when times are difficu & & & \\
\hline 6.30 I miss closeness and warmth around me & & & \\
\hline 6.31 I have a small circle of friends & & & \\
\hline 6.32 I have a lot of people that I can completely rel & & & \\
\hline 6.33 I have strong connections and relationships wi & & & \\
\hline 6.34 I am lonely & & & \\
\hline 6.35 I often feel isolated & & & \\
\hline 6.36 I can always rely on my friends when needed & & & \\
\hline
\end{tabular}




\title{
Chapter 4: Differential effects of adult education on adult learners' increase in social inclusion
}

\author{
Based upon De Greef, M., Verté, D. \& Segers, M. (submitted). Differential effects of adult \\ education on adult learners' increase in social inclusion.
}

\section{Abstract}

To date a significant share of the European population can be considered at risk of social exclusion. It has been argued that adult education programs are a powerful tool to support vulnerable adults increasing their social inclusion. This study aims to answer the question if and which subgroups of vulnerable adults experience an increase in social inclusion after joining adult education programs. The results of our study show that $46.3 \%$ of the participants experience an increase of social inclusion in terms of "activation and internalisation" and $41.0 \%$ experience an increase in "participation and connection". Based on trainee characteristics, results show that foreigners (compared to autochthone participants) and people who live together (compared to married, unmarried or widowed participants) experience a higher increase on several social inclusion variables of "activation and internalisation" and "participation and connection". Furthermore results show that men (compared to women), elderly (compared to younger participants) and learners who received school education at a primary level and have no professional qualification, experience a higher increase of social inclusion on one or few variables of social inclusion. On the contrary, the research results show no differences between subgroups based on (un)employment, motivational orientation and self-directedness in learning. 


\section{Background}

To date social exclusion is still a threat for European society. According to Eurostat (2010) $17 \%$ of the European population are considered at-risk-of-poverty in 2007. In addition $22.6 \%$ of children aged 15 years had a low proficiency in reading, which was higher than the $19.8 \%$ recorded in 2000 (Eurostat, 2010). Due to these and other comparable data of social exclusion the year 2010 has been designed as the "European year for combating poverty and social exclusion" (Grauman, 2010). In this context the European Commission underlines the necessity of investing time, effort and resources to lift at least 20 million people out of the risk of poverty and social exclusion by 2020 (Grauman, 2010). According to Bjørkøe (2009) the "New Poverty" of the last decennia includes the phenomenon of inhabitants experiencing a spiritual and social-cultural poverty, which refers to a broader conceptualisation of social exclusion than only economical marginalisation.

A variety of groups experience "New Poverty", for example low skilled inhabitants, unemployed, early school leavers, new immigrants, illiterate persons or the elderly. According to De la Fuente Anuncibay (2007) the reasons for each of these groups for being at risk of social exclusion differ. The group of immigrants for example risk social exclusion due to cultural backgrounds, linguistic aspects and the distance between their country of origin and the new country (Dahlstedt and Bevelander, 2010) and the distance to the labour market of the new country (Whalgren and Geiger, 2010). With respect to age, a part of the elderly can be seen as at risk of marginalisation due to socioeconomic inequality and rate of poverty (Dannefer, 2003). For the group of unemployed people, Bjørkøe (2009) describes that they experience a lack of achievement and self-actualisation and therefore risk social exclusion. Likewise the group of people, who are illiterate, form a substantial part of our society ( $22 \%$ of the population of the industrialised countries, UNICEF, 2008) and are at risk as being not able to read or write hampers participating in many aspects of society. In sum, different groups of vulnerable adults, discerned by different background characteristics have to cope with a variety of personal problems in daily life which hampers their inclusion in contemporary society.

For many years, the question has been raised as how to solve the growing problem of social exclusion. Already in the seventies the OECD pointed out that education can be a lever to increase social inclusion among inhabitants (Christian, 1974). Since then, education has been placed high on the European policy agenda as a one of "the key elements in policies to counteract social exclusion" (Nilsson, 2010, p. 260). Also outside Europe, attention has been asked for the role of education. For example during the Sixth International Conference on Adult Education (CONFINTEA VI) the UNESCO (2009) stressed the importance of adult education. Besides this also in Australia, Gleeson (2005) evidenced that individuals with very low numeracy skills gain positive and significant economic return after joining formal schooling. Even on a global scale, Peters (2004) points to the results of "the World Conference on Special Needs Education", which underlines the importance of education in order to build an "inclusive society". 
With respect to the role of education, authors like McClusky (1970) and Serrano-García and Bond (1994) stress that education is a strong tool to empower vulnerable adults. SerranoGarcía (1994) specifically states that learning can prohibit the struggle in daily life. If adults develop basic skills, they can improve their ability to cope with problems in daily life, like contacting official organisations, living together with others in one neighbourhood and making important choices in their lives. Given the aforementioned differences in background characteristics in the group of vulnerable adults, it can be argued that adults participating in education programs have a variety of learning needs and adult educators need to take them into account in order to be effective in terms of improving social inclusion (Labouvie and Baltes, 1973).

Although the importance of adult education in order to increase social inclusion seems to be apparent, hardly any evidence of its outcome is still available (Ananiadou, 2003). Indeed Nilsson (2010) underlines the need of research on the outcome of adult education. This study therefore tries to find an answer on the question if and which vulnerable adults experience an increase of social inclusion after joining programs of adult education.

\section{Outcome of training and education in terms of social inclusion}

According to Nilsson (2010) one of the best examples of an educational system promoting social inclusion is the "dual system". The "dual system" refers to learning in which technical and practical job skills are combined with social and personal behaviours (Deissinger, 2004). Because of this educational system learners are able to increase their competences in functioning in daily life as part of their social inclusion. The concept of social inclusion is a multidimensional one. Depending on societal institutions and sociologists the definition of social inclusion differs. One of the most holistic descriptions refers to the definition of The World Bank (2007). In their context social inclusion can be seen as "a process which ensures that those at risk of poverty and social exclusion gain the opportunities and resources necessary to participate fully in economic, social and cultural life and to enjoy a standard of living and well-being that is considered normal in the society in which they live" (The World Bank, 2007, p. 4). This description confirms the definition of Van Houten (2008) in which social inclusion can be seen as an ultimate participation of every citizen in his or her own way in all facets of society. In fact it refers to the self-control of a citizen (Van Regenmortel, 2009).

The aforementioned description of social inclusion of the World Bank (2007) includes four kinds of capital, namely financial, physical, human and social capital. Hence social inclusion can be interpreted as a multidimensional process. In this respect, social exclusion can be explained as a multidimensional disadvantage in terms of a lack of resources and quality of life (Levitas et al., 2007). Besides the lack of resources and quality of life, Scharf, Phillipson and Smith (2005) add the lack of participation and self-control. They describe social 
exclusion as a lack of material resources, social relations, civic activities, basic services and neighbourhood exclusion. Likewise the indicators of social exclusion according to the European Social Survey refers to the regularity of meeting with friends and relatives, taking part in social activities, self-rated physical health and mental health, self-rated income and the quality of the local area (Ogg, 2005). As a result of the different descriptions of social inclusion, we define social inclusion as:

- a multidimensional process of individuals who

- try to control and to cope with resources and services,

- take part in society and its activities,

- connect to social relations and

- feel included in the (local) area.

\section{Social inclusion explained as multidimensional process based on four pillars}

At any rate social inclusion refers to a multidimensional process of behavioural change based on the interaction of an individual with its environment in different situations (Endler and Magnusson, 1976; Krueger et al., 2008; Nye and Hargreaves, 2009). Eventually this interaction results in functional and emotional satisfaction defined as controlling and coping with resources and services, feeling included in the (local) area, taking part in society and activities and connecting to social relations. Thus the process of social inclusion can be interpreted in two different ways.

Firstly social inclusion is an interactive process between the individual and his or her environment. In this social-psychological context the individual is the central actor, who experiences social in- or exclusion. This experience can influence the development of the personal identity. Accordingly, social inclusion can be explained by three identity theories (Sullivan, 2002). Firstly Markus and Nurius (1986) describe the theory of Possible Selves by relating motivation and behaviour to the present and possible future self. Specifically, present behaviour is motivated by the current as well as the future (or possible) perspective of the self (Markus and Nurius, 1986). Referring to vulnerable adults, their behaviour will be inspired by their thoughts of who they hope to be or become. This development of the possible self influencing behaviour can be seen as a process of social inclusion. On the other hand Breakwell $(1986,1988)$ describes the Identity Process Theory by reflecting on the concept of identity as an interaction between four identity processes, namely self-esteem, self-efficacy, distinctiveness and continuity. If the identity is threatened by one or more events and an optimum level of these four principles is blocked, a coping strategy will be sought. Consequently social inclusion can be explained as functioning in daily life by reaching an optimum level of the four principles of identity. Thirdly, Hogg and Abrams (1988) explain the concept of social in- and exclusion by introducing the social identity paradigm. In this 
perspective individual behaviour occurs after identification with the group and its members (Kramer et al., 2001). Accordingly Bandura (2001, 2004, 2006) refers to the influence of reciprocal interactions (belonging to specific behavioural, cognitive and environmental factors) on human behaviour (Bandura, 2001, 2004, 2006; Santrock, 2008). This social cognitive theory of Bandura shows that the social environment of the learner is a learning forum, where learning occurs within social relationships (Renshaw, 2003).

Secondly the increase of social inclusion can result in a functional satisfaction (for example in reading one's own post) or in an emotional satisfaction (for example in becoming a member of a local organisation or council). The need for functional or emotional satisfaction differs per "marginalised group". According to Carstensen's socio-emotional selectivity theory (1995, $1998,2006)$ the elderly for example are more focused on gaining emotional than functional rewards (to be seen as gaining knowledge).

Thus the process of social inclusion consists of one's interaction with his or her environment in order to reach emotional or functional satisfaction (see figure 1). Specifically, the main axe of this figure is the discernment between the increase of social inclusion on an individual level (described as processes of activation and internalisation) on the one hand and a collective level on the other (described as processes of participation and connection). Firstly activation (process one) and internalisation (process two) explain the increase of social inclusion as a functional respectively an emotional reward for the individual himself. Secondly, participation (process three) and connection (process four) can be explained as the functional or emotional outcome for the individual in interaction with his or her environment.

Figure 1: Quadrant of Social Inclusion

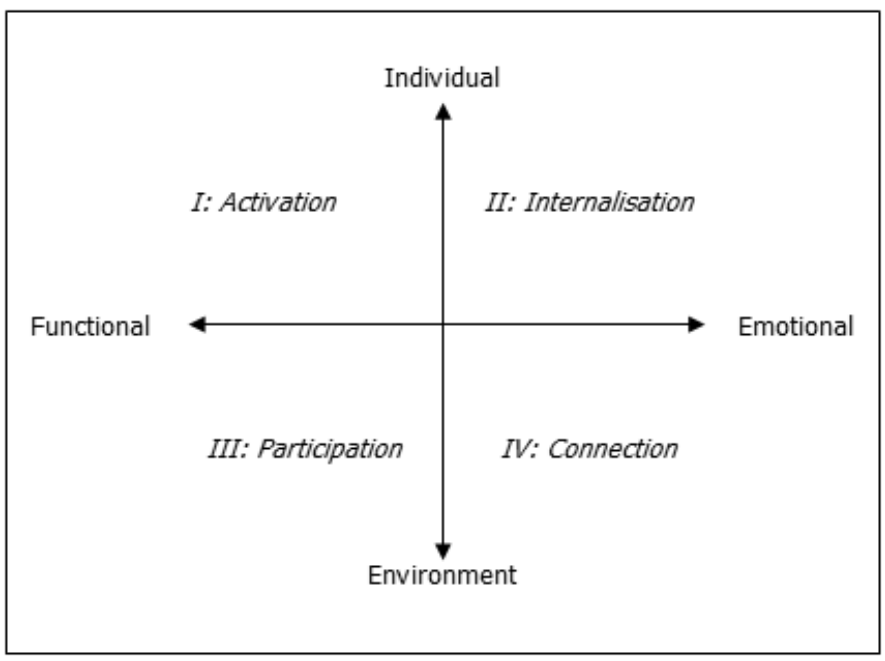




\subsection{Activation and internalisation}

In order to cope with practical daily problems vulnerable adults need to increase basic skills. In this context social inclusion refers to the functional outcome for the individual and can be seen as a process of activation. For example one can read the subtitles on TV or one is able to read and sort out his or her post. According to Bjørkøe (2009) activation concerns the involvement of learners in meaningful and communicative activities with a specific goal orientation. In this context activation leads to an increase of liveability within the direct surroundings (Fortuin and Keune, 1997). Accordingly the learner has the opportunity to increase his or her self-control (Fortuin and Keune, 1997; Krauss Whitbourne, 2005), in other words mastery (Ben-Zur and Michael, 2007). Moreover Santrock (2008) points out that mastery can lead to an increase in the stability of self-esteem.

Besides this the increase of feelings of happiness and safety (in terms of increase of emotional satisfaction for the individual him- or herself) can be seen as internalisation. More concrete Mastergeorge (2001) explains internalisation of a process in which an individual is satisfied with oneself and has the ability to lead his or her life in a responsible and happy way. Furthermore Ferguson and Mindel (2007) describe the feeling of being safe and satisfied with living in the neighbourhood as part of social inclusion. In this context the surroundings can influence the emotional satisfaction of the individual. More concrete examples of internalisation are the ability to solve problems by oneself and the feeling of respecting others.

\subsection{Participation and connection}

According to Bjørkøe (2009) participation is necessary in order to be social included. In this respect participation refers to a growing stability of the individual's connection with his or her environment (resulting in functional rewards). In other words increase of social inclusion can be explained as doing more things within the direct surroundings (Guildford, 2000). For example one organises activities in the neighbourhood or takes part in official organisations (Verté et al., 2007). Referring to participation Krauss Whitbourne (2005) argues that vulnerable adults participate by establishing reciprocal relationships with the environment. Due to being more active in doing things and joining more social activities vulnerable adults increase their rate of participation.

On the other hand the increase of neighbourhood attachment, functioning in social networks, civic participation (Li, Pickles and Savage, 2005) and social support (Gray, 2008) can be explained as an increase of connection (Colley, 1975; Priemus, 2005; Huisman et al., 2007; Smith, 2007). In this context, vulnerable adults have better or more contact with others and experience an emotional satisfaction after connection with the environment. According to Verté et al. (2007) social inclusion is a process of meeting others and developing new social interactions. Besides becoming more independent one becomes more intimate and 
experience more commitment to others (Santrock, 2008). To be more precise, one is more open towards others, feels more secure (Brennan, Clark and Shaver, 1998) and feels less lonely (De Jong-Gierveld, 1987). In this respect Antonucci and Akiyama (2002), Antonucci, Lansford and Akiyama (2001) and Antonucci, Vandewater and Lansford (2000) state that social support by the personal networks of individuals can also endeavour problem solving in daily life.

\section{The influence of trainee characteristics on transfer}

In the field of educational research many authors (e.g. Peters, 2004) have been discussing the problem of fairness and more specifically inequality of education. As Lynch and Baker (2005, p. 136) argue that "schools and colleges can and do contribute to social class based inequalities of educational resources through a host of mechanisms and procedures. Among the processes and procedures that we have identified as being within some degree of the control of the education system itself are the selection or admission procedures controlling school entry, the grouping procedures used to locate students in tracks or streams, and the systems of curriculum and syllabus design and assessment." They conclude (p. 139): "Whatever the reason may be for its lower status or exclusion from the syllabus, the fact that the life and culture of the economically subordinate are not studied in schools, reinforces the sense of their subordination in society." Given the heterogeneity of the adult learners joining programs of adult education (Chilvers, 2008), the question raises to what extent adult education programs have differential effects on increase in social inclusion for different subgroups of participants.

Participants in adult education programs have an important extent to a demographic and socio-economic background which has been evidenced as being significant barriers to social inclusion. In this respect, based on a study in twelve European countries, Tsakloglou and Papadopoulos (2002, p. 211) demonstrate that in most of the countries included in the study, "lack of full-time employment, low educational qualifications, lone parenthood, non-EU citizenship and bad health are positively and significantly associated with increased risk of social exclusion". In addition, family status, more precisely being an elderly citizen living alone or a member of an elderly couple is found to be negatively associated with the risk of social exclusion in Northern Europe but positively in Southern Europe. Verté et al. (2007) present comparable findings: several socio-demographic factors, more precisely gender, racial background, age, marital status, number of children and (un)employment are important predictors of social exclusion.

It is the question to what extent adult education programs are able to deal with the heterogeneity of their population and are able to support those subgroups, which are at higher risk of social inclusion than others, by equal opportunities. Moreover, adult education programs' participants differ in motivational orientations, or reasons for participating in adult 
education, which might be a barrier for realising learning gains. Finally, to a growing extent, adult education programs expect participants to actively take responsibility and initiative in learning. It might be questioned as to what extent participants showing low levels of selfdirectedness in learning are disadvantaged.

In summary, several background and individual characteristics can influence the learning outcomes in terms of social inclusion. In this study we will discuss gender, racial background, age, family composition, (un)employment, educational background, motivational orientation and self-directedness in learning.

\subsection{Gender}

According to Eurydice (2010) research on sex differences in learning results needs to be interpreted with caution due to the fact that studies may be stereotyped or biased towards one sex or the other. Nonetheless, differences in gender relate proportionately to achievement of success after joining education (Preece, 2010). According to the study of Eurydice (2010) girls tend to achieve better results on reading and boys show better results in mathematics in the later school years (Eurydice, 2010). According to Kivinen and Rinne $(1995,1996)$ these differences in gender, social inheritance of educational careers and inequality of educational opportunities occur not only in childhood, but through the whole (educational) lifespan. Therefore, we contend gender might influence outcomes of adult education in terms of increase of social inclusion on the participants.

\subsection{Racial background}

The problem of educational inequality of immigrant learners has been addressed in many studies, mainly focussing on compulsory education. Well-known are OECD PISA studies, with the 2006 study evidencing that immigrants show substantially lower achievements on reading, mathematical and science literacy skills (OECD, 2006).

This finding has been confirmed in many national studies. For example, Azzolini (2011) has reviewed empirical studies to point to the existence of substantial immigrant native differentials along several dimensions of educational attainment and achievement. The results indicate that immigrant learners do not only score lower on subjects like writing and reading but also display lower school attendance rates and lower probability of school completion. They face higher risks of grade retention, school delay, dropout, higher probability of enrolling in vocational schools and lower chances to enroll in general and pre academic schools. Azzolini (2011, p. 217) argues that "this gap is a consequence of a double disadvantage faced by students with migration background. On one hand, students with migration background are more likely than natives to live in socioeconomically deprived families and this accounts for a substantial part of their educational disadvantage. In addition to this traditional form of inequality, students with migration background face the 
hurdles of a new form of inequality, which is specifically linked to their migration background. That is to say, students with migration background are not disadvantaged, because of their poor socioeconomic conditions only, but also as a consequence of their migration background."

\subsection{Age}

Age has been evidenced to be related to participation in education as well as to the risk of social exclusion. According to Eurostat (2005) younger adults are more likely to join education than older adults. More concrete $50 \%$ of between 25 to 34 years old have participated in education programs besides $30 \%$ of the 55 to 64 years old, who joined courses or training (Eurostat, 2005). With respect to age and social exclusion, Verté et al. (2011) evidenced the influence of age on the rate of participation in society. More concrete, his research among circa 70.000 elderly show that the social network, besides informal care, doing voluntary work and being involved in activities concerning culture, differ per category of age, showing more participation among the young elderly (60 - 69 years old) and less participation of the elderly above 80 years.

In addition, given the increasing role of technology in daily life, many authors (e.g. Martin, 2009) describe the problems the ageing population experiences in daily life. Due to their age, the upcoming use of digital technology can be a threat for the liveability of elderly, because they lack competencies in using digital technology. Likewise Preece (2010) refers to an inquiry of NIACE, in which it is clear that besides investment in education of young adults, investment in older learners can be worthy not only to the increase of digital competencies, but in in a broader sense, namely in order to be active in society by using digital media such as email or filling in forms from official organisations. In this respect, it might be expected that different age groups show differences in increase in social inclusion after participating in adult education.

\subsection{Family status: marital status and number of kids}

Family circumstances, such as having a family and taking care of children can influence the learning process (Preece, 2010) but also the rate of social inclusion. For example negative stress such as family responsibilities can block the motivation to learn. According to Gray (2008) elderly who do not have a partner or are childless experience poor support from their social network. Accordingly the study of Verté et al. (2011) show that elderly who are divorced are the most vulnerable group. Indications are that divorced elderly or widowed do less voluntary work and are less often a member of an association (Verté et al., 2011). Given that marital status and number of children seem to influence the risk of social exclusion, we 
contend that family status might jeopardize the effect of participating in adult education in terms of enhancing social inclusion.

\section{5 (Un)employment}

Research of Tsakloglou and Papadopoulos (2002) shows a positive association between the lack of full-time employment and the increased risk of social exclusion. More concrete participants who are unemployed are more threatened to become social excluded from society. According to Cedefop (2007), 43\% of the learners, who are employed, participate in non-formal education and training in order to improve their competencies at work or their careers. For these learners having a job stimulates them in joining education. To summarise, having a job can influence learning and possibly the rate of social inclusion.

\subsection{Educational background}

According to the EU2010 (2010) the European percentage of early school leavers of $15 \%$ is problematic due to the fact that they are barred from becoming qualified for the labour market and other forms of schooling in our society. Given these early school leavers often have been experiencing learning problems in compulsory education (Vos, De Vries and Duvekot, 2007), it might be expected that, more than those with a successful prior education career, they experience problems in reaching the learning goals of adult education programs. Furthermore De Greef (2011) studied the different needs of low and high educated learners during digital learning courses. It became clear that low educated learners, in comparison with high educated learners preferred a content wise program based on their daily life. The extent to which the differential needs are carefully addressed by adult educators might influence if low educated participants are disadvantaged.

\subsection{Motivational orientation}

Although there are many different theoretical perspectives on the construct of motivation and its multidimensional nature resulting in an ongoing debate (Gegenfurtner, 2011), the role of motivational variables in the learning process is generally accepted. In this study, in line with current directions in motivation research (e.g. Mouratidis, Vansteenkiste, Sideridis and Lens, 2011), we address two dimensions of motivation, autonomous motivation and controlled motivation. In accordance with Gegenfurtner, Festner, Gallenberger, Lehtinen, and Gruber (2009), we define autonomous motivation as an internalised desire to participate in learning experiences that is initiated and governed by the self. For example participating in an adult education program offers the household opportunities to take care of financial matters. Controlled motivation refers to a desire to participate regulated by external rewards 
or sanctions. For example, adults subscribe to adult education programs in order to avoid financial sanctions.

In terms of motivational orientations, the group of adult education participants is therefore heterogeneous. Based on former research findings that autonomous motivation exhibits a stronger influence on intention to transfer than controlled motivation to transfer (Gegenfurtner, 2011), it might be expected that autonomous motivated participants show more increase on social inclusion after participating in adult education than controlled motivated participants.

\subsection{Self-directedness in learning}

Based on a review of the different theoretical perspectives on the construct of selfdirectedness in learning, Raemdonck et al. (2008) defines self-directed learning as "a tendency to take an active and self-starting approach to learning activities and situations and to persist in overcoming barriers and setbacks to learning". Brockett (1985, p. 55) argues that "there are studies available which provide evidence that hard-to-reach adults (such as disadvantaged blue-collar workers) can and do engage in self-directed learning" and that "the evidence of self-directed learning among the hard-to reach is quite strong". Following these arguments, Raemdonck (2006) conducted interviews with low qualified employees and found that there were large differences in the level of self-directed learning within this group of employees. Based on these findings it might be expected that in adult education programs groups of participants can be discerned based on their level of self-directedness in learning. Given the evidence of the importance of self-directed learning in realising learning gains (e.g. Ryan and Deci, 2000), the heterogeneity of the group of participants with respect to selfdirectedness in learning poses major challenges to adult education in realising outcomes.

\section{Research goals and research questions}

The current study aims to measure the outcome of adult education programs in terms of social inclusion of vulnerable adults.

To be more specific, we aim to explore differences between subgroups of participants with respect to increase in social inclusion (in terms of activation, internalisation, participation and connection) after joining programs of adult education. 


\section{Methodology}

\subsection{Sample}

At the beginning of the course 787 learners (response rate of $67 \%$ ) returned the questionnaire and 515 learners (response rate of 44\%) at completion. These learners are low qualified adult learners joining courses in adult education institutions. Specifically, the sample encompassed three different kinds of courses in order to increase social inclusion, namely 36 different basic skills courses, 40 different courses concerning digital competencies and 24 different language courses. These courses are part of the Dutch national educational program aiming to increase social inclusion and are provided by 31 regional adult education centres (with 39 different locations). In order to compare the impact of training programs in adult education every regional adult education centre was asked to involve two to four different training programs including one teacher per program. Finally every teacher handed over the questionnaires to their adult learners with a maximum of 30 participants per centre. According to table 1 , the majority of the vulnerable adults are autochthonal $(81.8 \%)$ and female $(68.7 \%)$. Furthermore most of the learners are 41 years and older $(78.2 \%)$, have two children $(42.6 \%)$, are married $(64.4 \%)$, are unemployed $(50.2 \%)$, have less than 10 years education (76\%) and attend the course voluntarily (63.5\%).

Table 1: Sample characteristics: Participants' background $(\mathrm{N}=787)$

\begin{tabular}{|c|c|}
\hline Characteristic / category & $\%$ \\
\hline \multicolumn{2}{|l|}{ Gender } \\
\hline Male & 29.7 \\
\hline Female & 68.7 \\
\hline \multicolumn{2}{|l|}{ Nationality } \\
\hline Autochthonal & 81.8 \\
\hline Foreign & 15.8 \\
\hline \multicolumn{2}{|l|}{ Age } \\
\hline $21-40$ & 16.9 \\
\hline $41-60$ & 32.9 \\
\hline $61-80$ & 45.3 \\
\hline \multicolumn{2}{|l|}{ Marital status } \\
\hline Married & 64.4 \\
\hline Unmarried & 16.8 \\
\hline Living together & 5.5 \\
\hline Widowed & 11.3 \\
\hline \multicolumn{2}{|l|}{ Number of children } \\
\hline 0 & 15.2 \\
\hline 1 & 10.9 \\
\hline 2 & 42.6 \\
\hline 3 & 20.1 \\
\hline 4 & 6.4 \\
\hline \multicolumn{2}{|l|}{ Highest level of education } \\
\hline Primary school & 2.0 \\
\hline Secondary school & 12.7 \\
\hline
\end{tabular}




\begin{tabular}{ll}
\hline Further education on level of middle class & 3.0 \\
Higher education & 28.2 \\
University & 31.1 \\
Other school systems & 12.7 \\
Total years of education & \\
\hline$<5$ & 33.7 \\
$6-10$ & 33.3 \\
$11-15$ & 21 \\
16-20 & 5.8 \\
\hline Professional qualification & \\
\hline Yes & 60.5 \\
No & 34.3 \\
Attending courses & \\
In behalf of work & 25.3 \\
Outside work & 14.1 \\
Both in behalf of and outside work & 31.8 \\
None & 22.6 \\
\hline Job & \\
\hline Paid work & 27.1 \\
Voluntary work & 14.5 \\
Both paid and voluntary work & 4.3 \\
None & 50.2 \\
\hline Motivation & \\
Voluntary & 63.5 \\
Sent by official organisation & 7.8 \\
Sent by employer or colleague & 2.9 \\
Encouraged by member of family, friend or acquaintance & 11.2 \\
\hline & \\
\hline
\end{tabular}

Note: Missing values are excluded in percentage calculations.

\subsection{Procedure}

On each location of the regional adult education centres teachers joined a plenary training and instruction by the researcher. For stratifying the low qualified learners every teacher received a standardised written instruction.

At the beginning of the course pretest data was collected concerning sociodemographic factors (gender, racial background, age, marital status, number of children and (un)employment), educational background (highest level of education, number of years of education, professional qualification and attendance of courses), motivation and selfdirectedness in learning. At the beginning as well as at the completion of the course data was gathered for the two variables of social inclusion, namely "activation and internalisation" and "participation and connection". 


\subsection{Instruments}

\subsubsection{Social inclusion}

De Greef, Segers and Verté (2010) developed and validated in a prior study the SITinstrument (instrument measuring Social Inclusion after Transfer). This instrument consists of two scales measuring social inclusion. Firstly "activation and internalisation", which has an eight-factor structure: national language skills ( 9 items), digital skills (3 items), international language skills ( 3 items), assertiveness (5 items), labour- and upbringing skills (4 items), voluntary work- and neighbourhood skills ( 3 items), contact skills (7 items) and financial skills (theoretical driven) (see table 2). CFA showed a good fit of the model to the data with $\chi 2$ of 1820,70 by $N=787$, CFI $=0.912$, RMSEA $=0.079$ and St RMR between 0.052 (see table 3).

The second scale of social inclusion, "participation and connection", which has a seven-factor structure, that is: meeting and attempting (4 items), meeting intimate contacts (4 items), attempting in associations in neighbourhood ( 7 items), being active in nature and sports (4 items), involving into arts and culture ( 2 items), getting a membership ( 4 items) and preventing loneliness (11 items) (see table 2). Also for this scale all the items (confirming the hypothetical factors) provide a good fit to the data with $\chi 2$ of 1956,50 by $N=787, \mathrm{CFI}=$ 0.884 , RMSEA $=0.069-0.79$ and St RMR $=0.063$.

\subsubsection{Self-directedness in learning}

The Raemdonck (2006) scale of self-directed learning with 14 items is used. The CFA results evidence a one-factor structure ( $\chi 2$ of 408,40 by $N=787$, CFI $=0.937$, RMSEA $=0.074$, St $\mathrm{RMR}=0.039$ ).

\subsubsection{Socio-economical backgrounds}

The background variables are: age, racial background, gender, marital status, number of children and (un)employment and educational background (highest level of education, number of years of education, professional qualification and attendance of courses).

\subsubsection{Motivational orientation}

One item is used to measure motivational orientation. This item refers to the reasons why the respondent decided to participate in an adult education program: namely voluntary, sent by an official organisation, sent by an employer or colleague or sent by an acquaintance, friend or member of the family. 
Table 2: Questionnaires used in this study, scales, example items

per scale and reliability coefficients $(\mathrm{N}=308)$

\begin{tabular}{|c|c|c|c|c|}
\hline Questionnaires & Scales & $\begin{array}{l}\mathrm{N} \text { of } \\
\text { items }\end{array}$ & $\begin{array}{l}\text { Example of items per } \\
\text { scale }\end{array}$ & $\begin{array}{l}\text { Cronbach's } \\
\text { Alpha }\end{array}$ \\
\hline $\begin{array}{l}\text { 1. Self-directed } \\
\text { learning }\end{array}$ & Self-directed learning & 14 & Taking initiative to learn & 0.899 \\
\hline 2. Activation \& & National language skills & 9 & Being able to read & 0.921 \\
\hline \multirow[t]{6}{*}{ Internalisation } & Digital skills & 3 & $\begin{array}{l}\text { Being able to use the } \\
\text { computer }\end{array}$ & 0.936 \\
\hline & International language skills & 3 & $\begin{array}{l}\text { Speaking different } \\
\text { languages }\end{array}$ & 0.889 \\
\hline & Assertiveness & 5 & $\begin{array}{l}\text { Being able to solve } \\
\text { problems }\end{array}$ & 0.894 \\
\hline & Labour- and upbringing skills & 4 & $\begin{array}{l}\text { Being able to solve } \\
\text { problems }\end{array}$ & 0.815 \\
\hline & $\begin{array}{l}\text { Voluntary work and neighbourhood } \\
\text { skills }\end{array}$ & 3 & Working as a volunteer & 0.673 \\
\hline & Contact skills & 7 & Respecting others & 0.881 \\
\hline 3. Participation \& & Meeting and attempting & 4 & Meeting people & 0.819 \\
\hline \multirow[t]{6}{*}{ Connection } & Meeting intimate contacts & 4 & Visiting family & 0.873 \\
\hline & $\begin{array}{l}\text { Attempting associations in } \\
\text { neighbourhood }\end{array}$ & 7 & $\begin{array}{l}\text { Organising activities in } \\
\text { neighbourhood }\end{array}$ & 0.847 \\
\hline & Being active in nature and sports & 4 & Enjoying sport activities & 0.613 \\
\hline & Involving into arts and culture & 2 & Enjoying the arts & 0.696 \\
\hline & Getting a membership & 4 & Member of a sports club & $0.572 *$ \\
\hline & Preventing loneliness & 11 & Example feeling empty & $0.800 *$ \\
\hline
\end{tabular}

Note 1: * Means that the items have a different scale, namely nominal and ordinal.

So this number reflects a Spearman Correlation.

Table 3: Fit indices and correlations factors SIT-model

\begin{tabular}{|c|c|c|c|c|c|}
\hline Factors $\downarrow$ & $\chi 2 / d f$ & $\begin{array}{l}\text { ST. } \\
\text { RMR }\end{array}$ & CFI & RMSEA & $\alpha$ (PCA) \\
\hline \multicolumn{6}{|l|}{ Dependent factors } \\
\hline Self-directed learning & 408,40 & 0.039 & 0.937 & 0.074 & 0.899 \\
\hline \multicolumn{6}{|l|}{ Independent factors } \\
\hline Activation \& Internalisation & 1820.70 & 0.052 & 0.912 & 0.079 & 0.954 \\
\hline Participation \& Connection & 1956.50 & 0.063 & 0.884 & 0.069 & 0.901 \\
\hline
\end{tabular}

\subsection{Statistical analyses}

As a first step, a change-variable is constructed for each subscale of the "activation and internalisation" scale and the "participation and connection" scale by computing the difference between T0 and T1 per variable.

Secondly in order to discern different patterns between subgroups a non-parametric analysis is conducted among trainee characteristics and the increase on social inclusion. The bivariate 
analyses of data, depending on the variables, were performed by means of Chi-square tests, Mann-Whitney tests and Kruskall-Wallis tests.

\section{Results}

\subsection{Descriptives}

The descriptives as presented in tables $4 \mathrm{~A}$ and $4 \mathrm{~B}$ show that $46.3 \%$ of the participants experience an increase in "activation and internalisation" and $53.7 \%$ a decrease or stabilisation in "activation and internalisation". Furthermore both tables show that $41.0 \%$ of the participants experience an increase in social inclusion in terms of "participation and connection" and 59\% show a decrease or stabilisation on "participation and connection". With respect to "activation and internalisation" as social inclusion indicators, the results show that $54 \%$ of the participants in our sample show an increase in "digital skills", but in contrast $23.9 \%$ have better "financial skills". With respect to "participation and connection" $44.3 \%$ of the participants are less lonely and only $21.8 \%$ have more memberships after participating in adult education programs.

Table 4A: Means and standard deviation of change in social inclusion variables for increase of social inclusion

\begin{tabular}{|c|c|c|c|c|c|c|c|}
\hline $\begin{array}{l}\text { Dependent variables of social } \\
\text { inclusion } \downarrow\end{array}$ & $\begin{array}{l}\text { Mean } \\
\text { To }\end{array}$ & SD T0 & $\begin{array}{l}\text { Mean } \\
\text { T1 }\end{array}$ & SD T1 & $\begin{array}{l}\text { Mean of } \\
\text { change }\end{array}$ & $\begin{array}{l}\text { SD of } \\
\text { change }\end{array}$ & $\begin{array}{l}\text { \% of population } \\
\text { experiencing } \\
\text { increase }\end{array}$ \\
\hline Activation and internalisation & 6.83 & 1.37 & 7.60 & 1.24 & 0.77 & 0.88 & 46.3 \\
\hline National language skills & 7.15 & 1.42 & 8.22 & 1.23 & 1.08 & 1.02 & 34.5 \\
\hline Digital language skills & 5.03 & 2.23 & 7.55 & 1.98 & 2.52 & 2.01 & 54.7 \\
\hline International language skills & 4.70 & 2.58 & 6.73 & 2.35 & 2.03 & 1.53 & 45.2 \\
\hline Assertiveness & 6.70 & 1.67 & 7.99 & 1.38 & 1.29 & 1.29 & 40.9 \\
\hline Labour- and upbringing skills & 5.99 & 2.14 & 7.78 & 1.86 & 1.78 & 1.35 & 29.7 \\
\hline $\begin{array}{l}\text { Voluntary work- and } \\
\text { neighbourhood skills }\end{array}$ & 3.81 & 2.22 & 6.32 & 2.05 & 2.50 & 1.65 & 35.4 \\
\hline Contact skills & 7.12 & 1.73 & 8.30 & 1.34 & 1.18 & 1.18 & 35.3 \\
\hline Financial skills & 6.00 & 2.36 & 7.98 & 2.01 & 1.98 & 1.35 & 23.9 \\
\hline Participation and Connection & 4.03 & 1.00 & 4.30 & 1.14 & 0.64 & 0.61 & 41.0 \\
\hline $\begin{array}{l}\text { Attempting in associations and } \\
\text { neighbourhood }\end{array}$ & 3.06 & 2.06 & 4.77 & 2.34 & 1.71 & 1.25 & 41.4 \\
\hline Being active in nature and sports & 5.41 & 1.79 & 6.94 & 1.58 & 1.53 & 1.32 & 30.9 \\
\hline Involving into arts and culture & 3.98 & 2.06 & 6.60 & 1.82 & 2.63 & 1.68 & 29.3 \\
\hline Getting a membership & 1.23 & 0.26 & 1.60 & 0.30 & 0.36 & 0.22 & 21.8 \\
\hline Meeting and attempting & 5.91 & 1.90 & 7.66 & 1.60 & 1.75 & 1.58 & 32.4 \\
\hline Meeting intimate contacts & 7.24 & 1.36 & 8.27 & 1.16 & 1.02 & 1.06 & 36.4 \\
\hline Preventing loneliness & 2.25 & 0.52 & 2.62 & 0.39 & 0.37 & 0.36 & 44.3 \\
\hline
\end{tabular}


Table 4B: Means and standard deviation of change in social inclusion variables for stabilisation or decrease of social inclusion

\begin{tabular}{|c|c|c|c|c|c|c|c|}
\hline $\begin{array}{l}\text { Dependent variables of social } \\
\text { inclusion } \downarrow\end{array}$ & $\begin{array}{l}\text { Mean } \\
\text { To }\end{array}$ & SD TO & $\begin{array}{l}\text { Mean } \\
\text { T1 }\end{array}$ & SD T1 & $\begin{array}{l}\text { Mean of } \\
\text { change }\end{array}$ & $\begin{array}{l}\text { SD of } \\
\text { change }\end{array}$ & $\begin{array}{l}\% \text { of population } \\
\text { experiencing } \\
\text { stabilisation or } \\
\text { decrease }\end{array}$ \\
\hline Activation and internalisation & 7.20 & 1.19 & 5.28 & 2.36 & -1.92 & 2.11 & 53.7 \\
\hline National language skills & 8.41 & 2.18 & 6.73 & 2.71 & -1.70 & 2.44 & 65.5 \\
\hline Digital language skills & 7.84 & 2.38 & 6.20 & 3.23 & -1.64 & 2.50 & 45.3 \\
\hline International language skills & 6.56 & 2.53 & 4.54 & 3.05 & -2.02 & 2.29 & 54.8 \\
\hline Assertiveness & 7.81 & 1.25 & 5.77 & 2.67 & -2.05 & 2.54 & 59.1 \\
\hline Labour- and upbringing skills & 6.57 & 2.72 & 4.34 & 3.09 & -2.22 & 2.53 & 70.3 \\
\hline $\begin{array}{l}\text { Voluntary work- and } \\
\text { neighbourhood skills }\end{array}$ & 4.41 & 2.61 & 2.84 & 2.28 & -1.58 & 1.96 & 64.6 \\
\hline Contact skills & 8.08 & 1.23 & 5.74 & 3.03 & -2.34 & 2.74 & 64.7 \\
\hline Financial skills & 8.44 & 1.57 & 6.40 & 3.20 & -2.05 & 2.90 & 76.1 \\
\hline Participation and Connection & 4.30 & 0.93 & 3.43 & 1.39 & -1.08 & 1.13 & 59.0 \\
\hline $\begin{array}{l}\text { Attempting in associations and } \\
\text { neighbourhood }\end{array}$ & 3.35 & 2.39 & 2.16 & 2.00 & -1.20 & 1.65 & 58.6 \\
\hline Being active in nature and sports & 7.23 & 1.90 & 5.22 & 2.90 & -2.01 & 2.41 & 69.1 \\
\hline Involving into arts and culture & 4.99 & 3.00 & 3.29 & 2.90 & -1.70 & 2.08 & 70.7 \\
\hline Getting a membership & 1.39 & 0.32 & 1.24 & 0.29 & -0.15 & 0.26 & 78.2 \\
\hline Meeting and attempting & 7.79 & 1.68 & 5.58 & 2.87 & -2.21 & 2.41 & 67.6 \\
\hline Meeting intimate contacts & 8.48 & 1.22 & 6.64 & 2.84 & -1.84 & 2.50 & 63.6 \\
\hline Preventing loneliness & 2.66 & 0.43 & 2.52 & 0.47 & -0.14 & 0.18 & 55.7 \\
\hline
\end{tabular}

\subsection{Differences between subgroups}

\subsubsection{Gender}

With respect to gender, the results (table $5 \mathrm{~A}, 6 \mathrm{~A}$ ) hardly show any differences for the different social inclusion indicators. Only for "assertiveness" the male participants show a higher increase than for the women $(U(405)=14.905 .5 ; p=0.041)$.

\subsubsection{Racial background}

Groups with different ethnic backgrounds show different patterns in the increase of social inclusion. Specifically, foreign learners show a higher increase on the variables "national language skills" $(\mathrm{U}(417)=9422.5 ; \mathrm{p}=0.028)$, "meeting and attempting" $(\mathrm{U}(407)=8695$; $\mathrm{p}=0.021)$ and "meeting intimate contacts" $(\mathrm{U}(415)=9222.5 ; \mathrm{p}=0.018)$ than autochthone learners. Furthermore learners born in the Netherlands show a higher increase on "involving into arts and culture" $(U(370)=8065 ; p=0.039)$ than foreign learners. 


\subsubsection{Age}

The results show differences between age groups. People of 41 years and older show a higher increase on "digital skills" than younger people. Besides this people of 40 years ( $r$ $(402)=0.000, p<0.01$ ) and younger show a higher increase on "labour- and upbringing skills" compared to older people $(r(318)=0.023, p<0.05)$.

\subsubsection{Family composition}

Family related variables seem to be important. Comparison is made with participants who are married, unmarried or widowed, participants who live together experience a higher increase on the scale "activation and internalisation" $(H(3,430)=12.665, \mathrm{p}=0.005)$ and more specifically in "national language skills" $(H(3,416)=19.568, p=0.000)$, "digital language skills" $(H(3,405)=10.754, p=0.013)$, "assertiveness" $(H(3,404)=18.266, p=$ $0.000)$, "labour- and upbringing skills" $(\mathrm{H}(3,321)=7.925, \mathrm{p}=0.048)$ and "contact skills" $(\mathrm{H}$ $(3,393)=18.328, p=0.000)$. Besides this they experience a higher increase on the scale "participation and connection", namely on "meeting and attempting" $(\mathrm{H}(3,406)=9.451, \mathrm{p}=$ $0.024)$ and "meeting intimate contacts" $(H(3,414)=9.978, \mathrm{p}=0.019)$.

Taking into account the number of children participants have, learners who do not have any children experienced the highest increase on "assertiveness" and learners who have 4 children and more experienced less increase on "assertiveness" $(r(403)=0.034, p<0.05)$. Besides this learners with 4 or more children experienced less increase on "preventing loneliness" than learners with 4 children or less $(H(5,420)=12.414, p=0.030)$.

\subsection{5 (Un)employment}

Tables $5 \mathrm{~A}$ and $6 \mathrm{~A}$ show that employment of the participant influences the increase of a social inclusion variable, namely "digital skills". Tables $5 \mathrm{~A}$ and $6 \mathrm{~A}$ show that unemployed learners experience a higher increase on "digital skills" than people who are employed or are involved in voluntary work $(\mathrm{H}(3,400)=15.784, \mathrm{p}=0.001)$.

\subsubsection{Educational background}

The educational background of learners also shows different patterns of increase of social inclusion (see tables 5B and 6B). Learners with (special) primary school education experience the highest increase of "international language skills" and learners with higher or university education show the least increase of "international language skills" ( $r$ (336) = $0.023, p<0.05)$. This is also the case for the increase of "meeting intimate contacts" ( $r$ $(364)=0.041, p<0.05)$. Besides this people with a professional qualification show less increase in "getting a membership" than people who are unqualified $(r(359)=0.043, p<$ $0.05)$. Learners who did not attend any courses show less increase in "voluntary work- and neighbourhood skills" than people who attend courses in behalf of an employer, outside of work or both $(\mathrm{H}(3,310)=5.210, \mathrm{p}=0.040)$. 


\subsubsection{Motivational orientation}

Finally learners who joined education voluntary or are encouraged by a member of a family, friend or acquaintance experienced less increase on "financial skills" than learners who are sent by an official organisation, by their employer or a colleague $(H(3,350)=7.941, p=$ 0.047) (see tables 5B and 6B).

\subsubsection{Self-directedness in learning}

According to table $6 \mathrm{~B}$ the rate of self-directedness in learning does not show different patterns towards increase of social inclusion. 


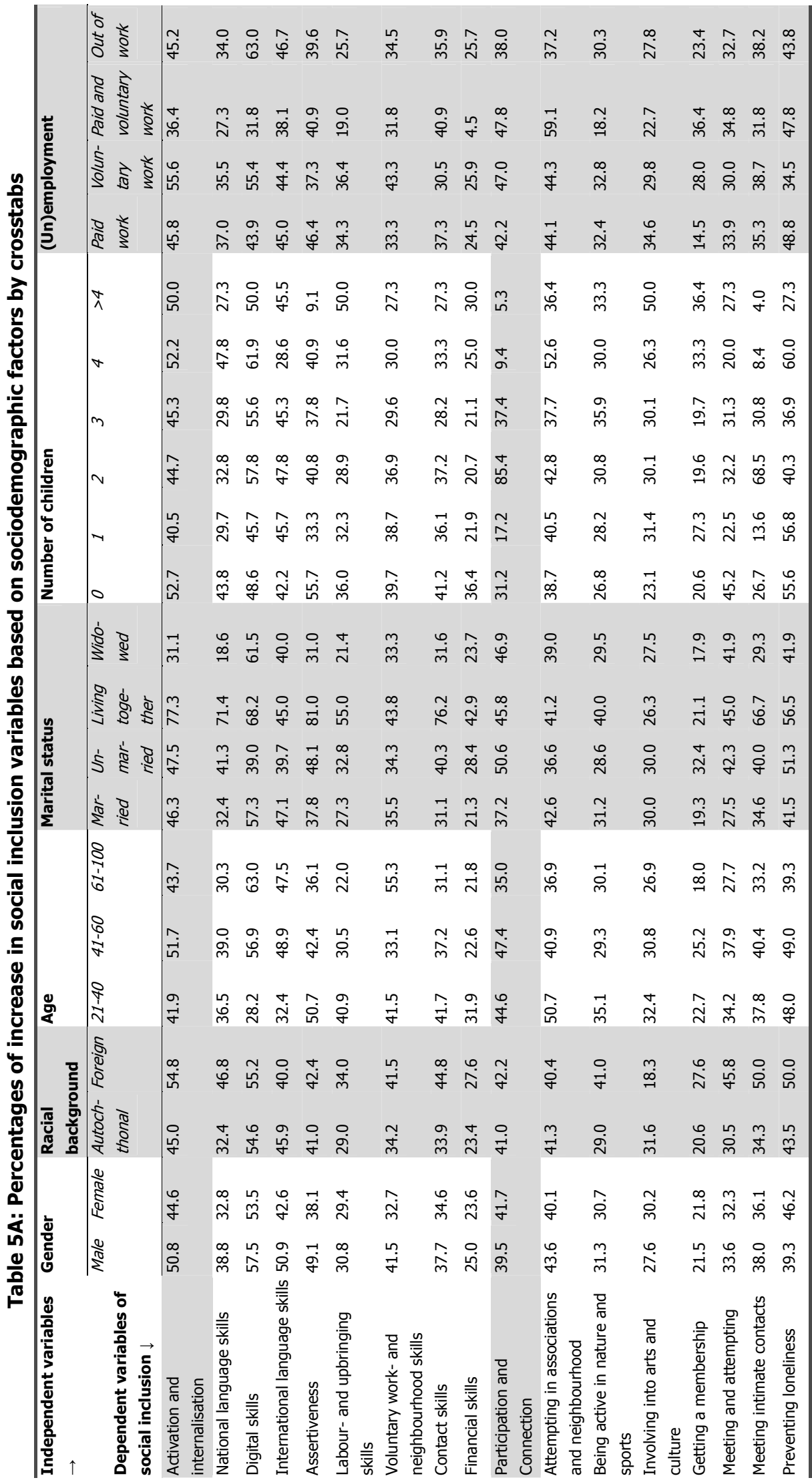




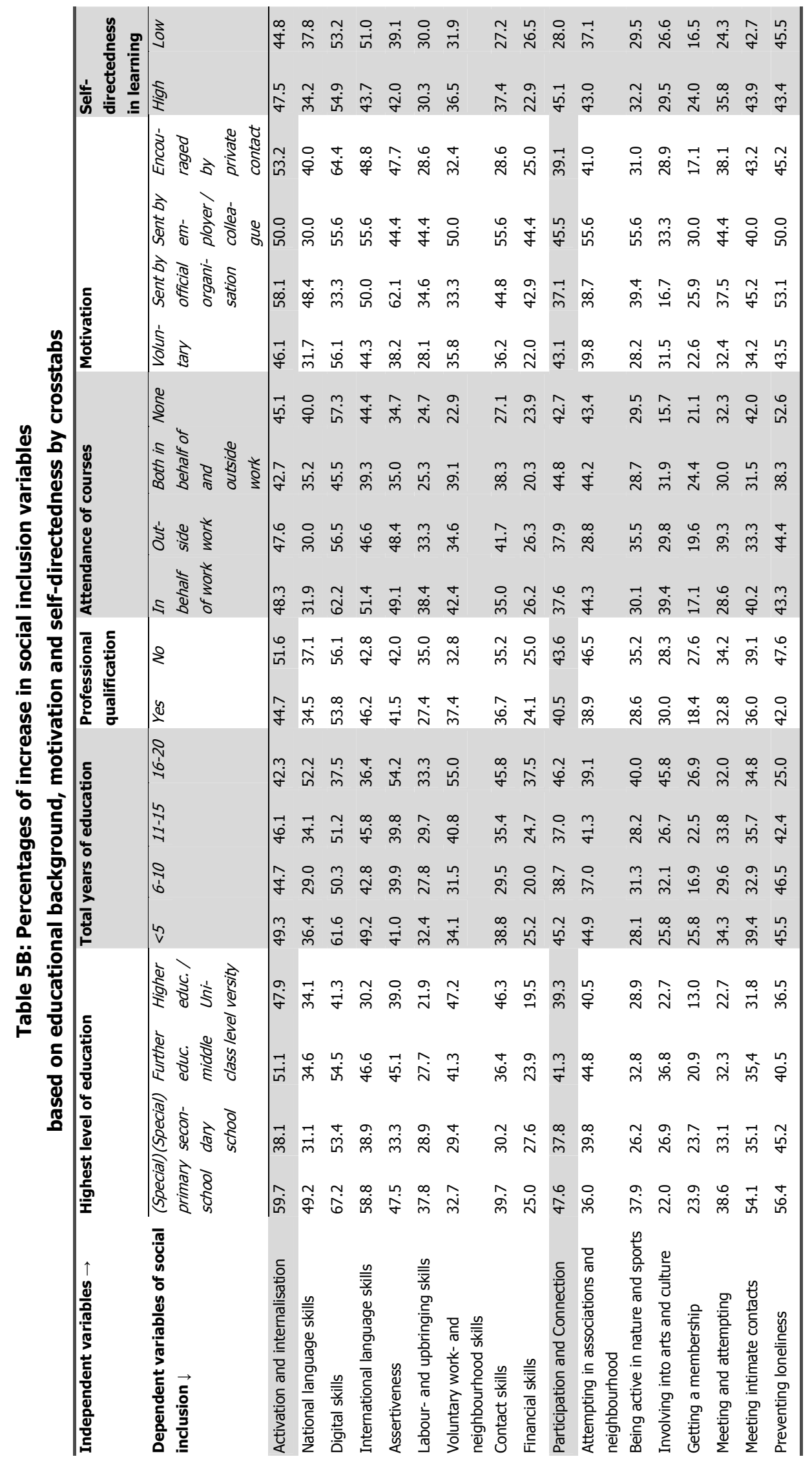




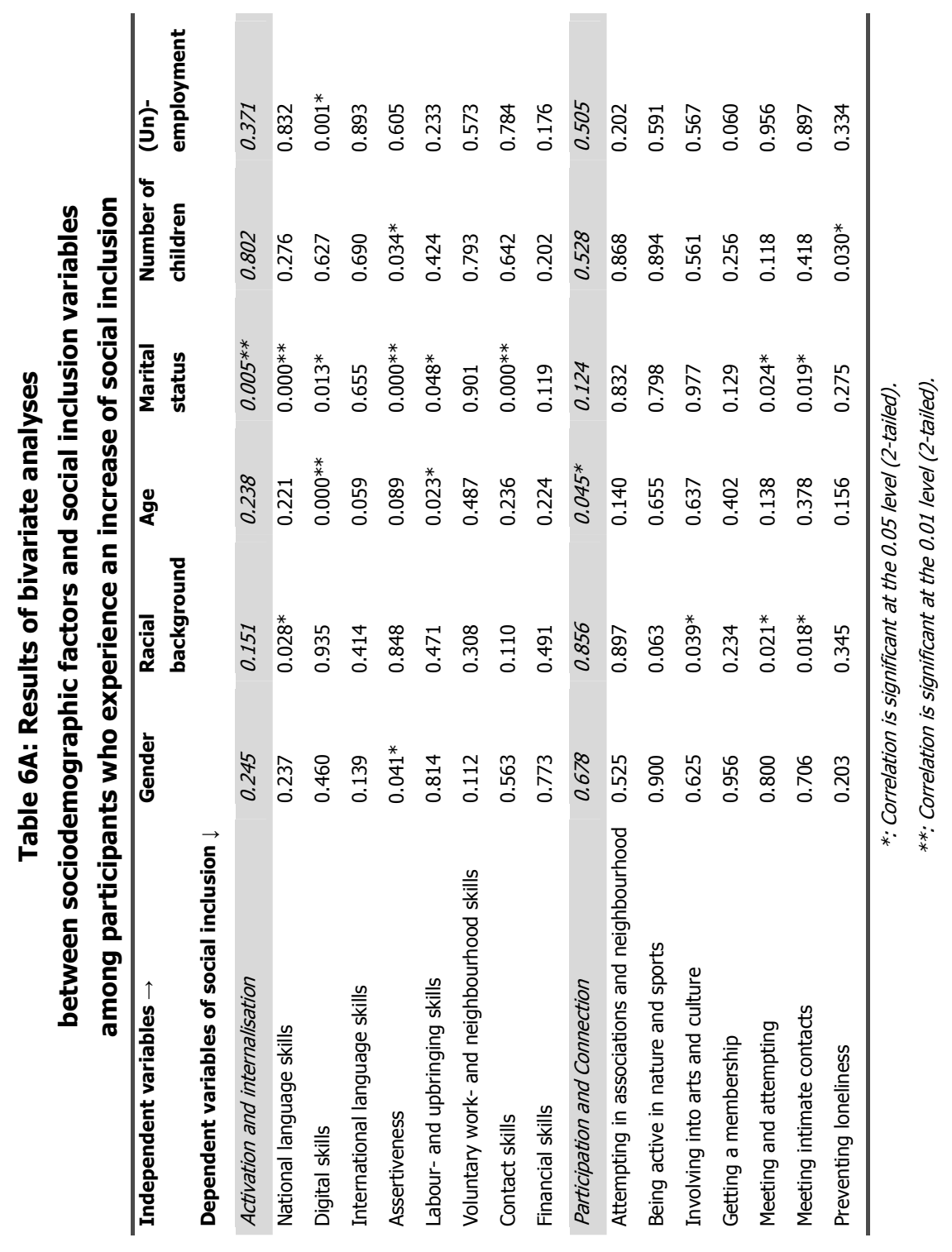




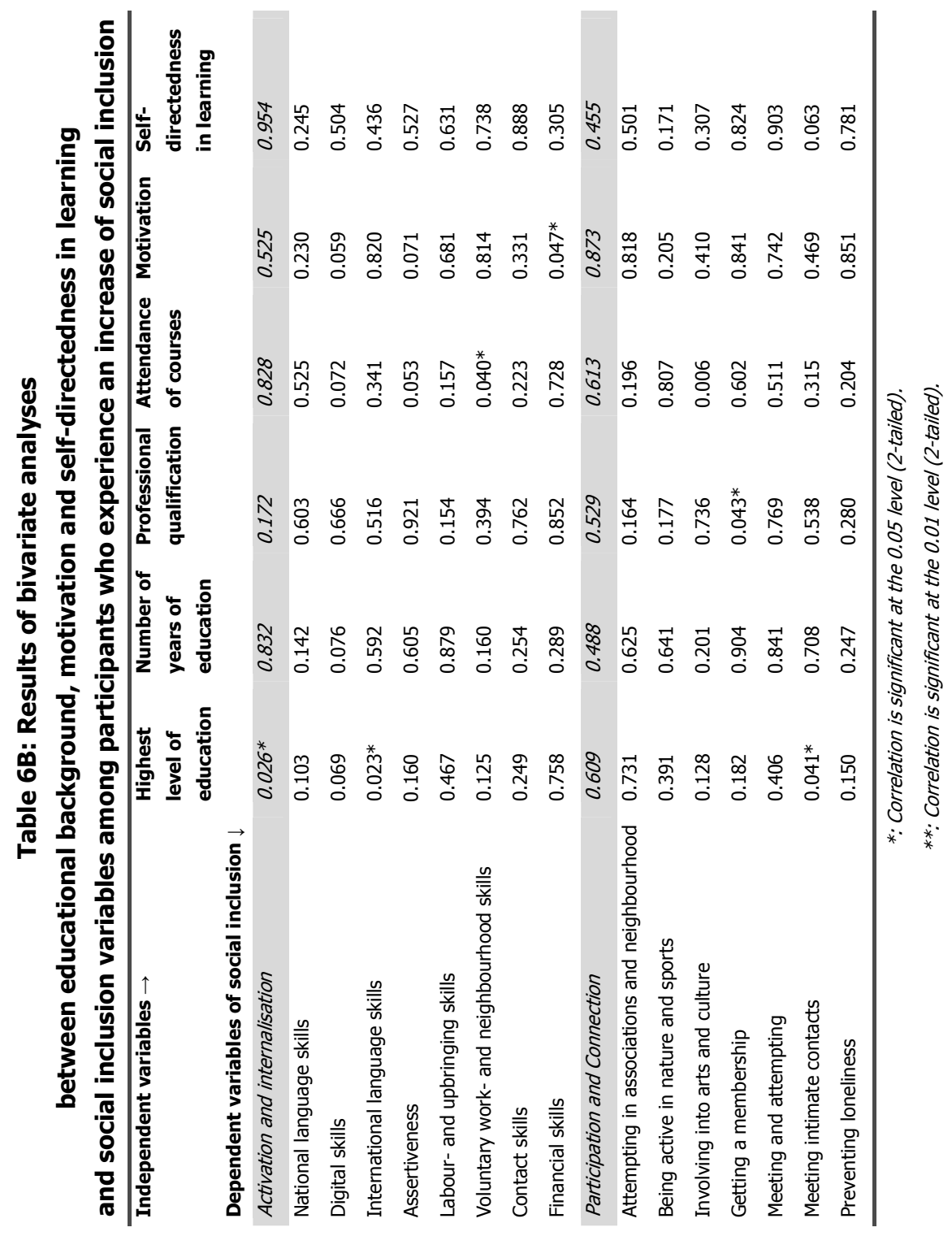




\section{Conclusions and discussion}

With this study we aim to gain insight in the question as to what extent subgroups of vulnerable adults differ in the increase of social inclusion after joining adult education. Our results show that $46.3 \%$ of the participants experience an increase of social inclusion on the subscale "activation and internalisation" besides $41.0 \%$ of the participants, who experience an increase of social inclusion on the subscale "participation and connection". Furthermore the percentage of learners experiencing an increase of social inclusion, varies from $21.8 \%$ ("getting a membership") to $54.7 \%$ ("digital language skills").

A closer look at the results shows that some results confirm earlier research, but other results show different findings. Firstly according to the aforementioned gender differences between language skills among men and women by Eurydice (2010), our research does not show any differences for these subgroups on national language skills. According to our findings we can only confirm that men experienced more increase on assertiveness. Secondly, Martin (2009) stated that the elderly have to internalise more digital skills concerning the upcoming use of technology. This has been confirmed by our results that older learners show a higher increase on digital skills than younger learners.

As to family composition, our findings show that people with few children show a higher increase of assertiveness and are less isolated. According to Gray's research (2008), elderly without children receive insufficient support from their social network. Therefore after joining an education program their increase in assertiveness and prevention of loneliness will probably be higher than for people who already have a strong social network. Our findings seem to support this reasoning.

Furthermore educational background indeed shows that people with limited education (for example (special) primary school) show a higher increase on certain skills, such as international language skills and meeting intimate contacts compared to learners with higher levels of education.

According to the aforementioned earlier research we can assume to find different patterns for subgroups concerning background variables of (un)employment, motivational orientation and self-directedness in learning. The lack of significant results for the variables (un)employment and motivational orientation might be caused by the sensitivity of our measures. Besides this we assume that the lack of association between self-directedness in learning and increase in social inclusion can be due to the approach in the programs of adult education included in this study, which probably do not appeal to the self-directedness in learning of the learners.

But the most striking results are those concerning racial background and marital status. Mostly foreigners and people who live together show a higher increase on four or more specific variables of social inclusion than autochthone learners and people who are married, unmarried and widowed. Likewise, the research of Verté et al. (2011) showed that divorced 
and widowed elderly experienced more social exclusion. Secondly the higher increase on several variables of social inclusion encountered by foreigners compared to autochthone learners confirms earlier research results that foreigners are more urged to improve their social inclusion than autochthone learners (Whalgren and Geiger, 2010). Differences can possibly be explained by the fact that some foreign learners are more low skilled than autochthone learners at the beginning of the course. Possibly they can experience a higher increase on social inclusion due to their marginalised position at the beginning of the course. However we should be cautious interpreting our research results. Considering our sample, some subgroups are fairly small and this can possibly influence the different patterns between the subgroups of marital status and racial background. Besides this a different position of some subgroups at the beginning of the course can result in differences in experiencing increase of social inclusion. Due to the fact that some subgroups experience a more marginalised position, they can possibly have more possibilities in experiencing increase in social inclusion at the end of the course. As a result some subgroups can experience a higher increase than others.

The current study shows several directions for future research. Firstly our research only concentrates on Dutch learners. In order to be able to generalise our findings we suggest cross cultural studies supposing that each country has different education systems and approaches with specific targetgroups. Besides this taking into account that some targetgroups in our study are pretty small we should propose to increase the sample size of some targetgroups in order to get better research results. Thirdly, in this study we focussed on the influence of individual variables on the increase of social inclusion. However, it might be inspected that the training design features of the adult education programs influence its effects and there is insight needed in how they interact with the variables addressed in this study.

Concluding we can confirm that particular groups of vulnerable adults experience an increase of social inclusion after joining adult education programs or lifelong learning programs. In other words vulnerable adults find a better place in daily society by coping with problems in daily life after learning. This is not the case for all vulnerable adults, but the results show that a significant share of the learners experience an increase of social inclusion. The next challenge is to find out which element of the surroundings of the learner is the specific lever for this learning success.

\section{References}

Ananiadou, K. (2003). The benefits to employers of raising workforce basic skill levels: a review of the literature. London: National Research and Development Centre for Adult Literacy and Numeracy. Antonucci, T. C. \& Akiyama, H. (2002). Aging and close relationships over the life span. International Society for the Study of Behavioural Development Newsletter (1, Serial No. 41), 2 - 5. 
Antonucci, T. C. Lansford, J. E. \& Akiyama, H. (2001). The impact of positive and negative aspects of marital relationships and friendships on the well-being of older adults. In J. P. Reinhardt (Ed.), Negative and positive support. Mahwah, NJ: Erlbaum.

Antonucci, T. C., Vandewater E. A. \& Lansford, J. E. (2000). Adulthood and aging: Social processes and development. In A. Kazdin (Ed.), Encyclopedia of Psychology Washington. DC \& New York: American Psychological Association and Oxford University Press.

Azzolini, D. (2011). A new form of educational inequality? What we know and what we still do not know about the immigrant-native gap in Italian schools. Italian Journal of Sociology of Education, 1, 197 222.

Bandura, A. (2001). Social cognitive theory. Annual Review of Psychology. Vol. 52. In J. W. Santrock (2008), Life-span development. New York: McGraw-Hill, 46 - 47.

Bandura, A. (2004). Toward a psychology of human agency. Paper presented at the meeting of the American Psychological Society, Chicago. In J. W. Santrock (2008), Life-span development. New York: McGraw-Hill, 46 - 47.

Bandura, A. (2006). Going global with socio cognitive theory: From prospect to paydirt. In S. I. Donaldson, D. E. Berger \& K. Pezdek (Eds.), The rise of applied psychology: New frontiers ad rewarding careers. Mahwah, NJ: Erlbaum. In J. W. Santrock (2008), Life-span development. New York: McGraw-Hill, 46 $-47$.

Ben-Zur, H. \& Michael, K. (2007). Men's affective reactions life events: the roles of coping strategies and personal outcomes. The Journal of Men's Health \& Gender, Vol. 4 (3), 358.

Bjørkøe, J. A. (2009). Starting from the heart. Copenhagen: Kofoed's School Publications.

Breakwell, G. M. (1986). Coping With Threatened Identities. London: Methuen.

Breakwell, G. M. (1988). Strategies adopted when identity is threatened. Revue Internationale de Psychologie Sociale, 1 (2), 189 - 203.

Brennan, K. A., Clark, C. L., Shaver, P. R. (1998). Self-report measurement of adult romantic attachment: An integrative overview. In J. A. Simpson \& W. S. Rholes (Eds.), Attachment theory and close relationships. New York: Guilford Press. In J. W. Santrock (2008), Life-span development. New York: McGraw-Hill, 497.

Brockett, R.G. (1985, October). Self-directed learning: Research trends and practice issues. Presented at the National Adult Education Conference, Milwaukee, WI.

Byrne, B. M. (2001). Structural equation modeling with AMOS: Basic concepts, applications, and programming. Mahwah, NJ: Erlbaum.

Carstensen, L. L. (1995). Evidence for a life-span theory of socioemotional selectivity. Current Directions in Psychological Science, 4, 151 - 156. In J. W. Santrock (2008), Life-span development. New York: McGraw-Hill, 651 - 652.

Carstensen, L. L. (1998). A life-span approach to social motivation. In J. Heckhausen \& C. Dweck (Eds.), Motivation and self-regulation across the life-span. New York: Cambridge University Press. In J. W. Santrock (2008), Life-span development. New York: McGraw-Hill, 651 - 652.

Cedefop (2012). Learning while working: how skills development can be supported through workplace learning. 17-03-2012. <http://www.cedefop.europa.eu/en/articles/18875.aspx>. 
Chilvers, D. (2008). Segmentation of Adults by Attitudes Towards Learning and Barriers to Learning. London: DIUS.

Christian, D. E. (1974). International Social Indicators: The OECD Experience. Social Indicators Research 1 (2), 169.

Colley, D. G. (1975). A social change index - an objective means to discern and measure the relative current social condition of cities, towns, and their sub-communities. Social Indicators Research, 1975 (1), 26.

Dahlstedt, I. \& Bevelander, P. (2010). General versus vocational education and employment integration of immigrants in Sweden. Journal of Immigrant and Refugee Studies, 8 (2), 158 - 193.

Dannefer, D. (2003). Cumulative Advantage / Disadvantage and the Life Course: Cross-Fertilizing Age and Social Science Theory. Journal of Gerontology: Social Sciences 58B (6), 327 - 337.

De Greef, M. (2011). Ondersteuning en certificering van digitaal leren voor laagopgeleiden. 'sHertogenbosch: Artéduc.

De Greef, M., Segers, M. \& Verté, D. (2010). Development of the SIT, an instrument to evaluate the transfer effects of adult education programs for social inclusion. Studies in Educational Evaluation (36), 42 - 61.

Deissinger, T. (2004). Apprenticeship systems in England and Germany: decline and survival. Towards a history of vocational education and training (VET) in Europe in a comparative perspective. Cedefop Panorama Series 103. Luxembourg: Office for Official Publications of the European Communities.

De Jong - Gierveld, J. \& Van Tilburg, T. (2008). De ingekorte schaal voor algemene, emotionele en sociale eenzaamheid. Tijdschrift voor Gerontologie en Geriatrie / TGG, 39 (1), 12.

De la Fuente Anuncibay, R. (2007). Social, personal and educational constraints on access to employment among groups at risk of social exclusion: contributions from an employment observatory. Journal of Vocational Education and Training, 59 (4), 435 - 449.

Endler, N., S. \& Magnusson, D. (1976). Toward an interactional psychology of personality. Psychological Bulletin, 83, 956 - 974.

EU2010 (2010). Ministers reach wide-ranging agreement to reduce school drop-out rate. 27-12-2010. <http://www.eu2010.es/en/documentosynoticias/noticias/may11_consejoeducacion.html>.

Eurostat (2005). Lifelong learning in Europe. Luxembourg: European Communities.

Eurostat (2010). Combating poverty and social exclusion. Luxembourg: European Union.

Eurydice (2010). Gender Differences in Educational Outcomes: Study on the Measures Taken and the Current Situation in Europe. Brussels: Education, Audiovisual and Culture Executive Agency.

Ferguson, K. M. \& Mindel, C. H. (2007). Modeling Fear of Crime in Dallas Neighborhoods: A test of Social Capital Theory. Crime \& Delinquency 53 (2), 322 - 349.

Fortuin, K. \& Keune, C. (1997). Anders praten over jeugd: Naar een begrippenkader voor preventief jeugdbeleid. Utrecht: Verwey-Jonker Instituut.

Gegenfurtner, A. (2011). Motivation and transfer in professional training: A meta-analysis of the moderating effects of knowledge type, instruction, and assessment conditions. Educational Research Review 6, $153-168$. 
Gegenfurtner, A., Festner, D., Gallenberger, W., Lehtinen, E., \& Gruber, H. (2009). Predicting autonomous and controlled motivation to transfer training. International Journal of Training and Development, 13 (2), 124 - 138.

Gleeson, L. (2005). Economic returns to education and training for adults with low numeracy skills. Adelaide: National Centre for Vocational Education Research.

Grauman, B. (2010). Getting out of poverty. Luxembourg: European Commission.

Gray, A. (2008). The social capital of older people. Ageing \& Society (29), 5 - 31.

Guildford, J. (2000). Making the case for social and economic inclusion. Canada Atlantic Region: Population and Public Health Branch.

Hogg, M. A. \& Abrams, D. (1988). Social Identifications. London: Routledge.

Huisman, J., Pijls, T., Van Hoeij, J., Van Voorst van Beest, K., Boonaerts, Y. \& Lens, M. (2003). Portfolio sociale competenties: Primair onderwijs, vmbo, mbo. 's-Hertogenbosch: CINOP.

Kivinen, O. \& Rinne, R. (1995). The social inheritance of education: equality of educational opportunity among young people in Finland. Education, 15.

Kivinen, O. \& Rinne, R. (1996). Higher education, mobility, and inequality: the Finnish case. European Journal of Education, 31 (3), p. 289 - 310.

Kramer, R., Hanna, B., Su, S. \& Wei, J. (2001). Collective identity, collective trust and social capital: Linking group identification and group cooperation. In M. Turner (Ed), Groups at work. London: Erlbaum.

Krauss Whitbourne, S. (2005). Adult development \& aging: Biopsychological perspectives. Hoboken: John Wiley \& Sons, Inc.

Krueger, R. F., South, S., Johnson, W. Iacono, W. (2008). The heritability of personality is not always 50\%: Gene-environment interactions and correlations between personality and parenting. Journal of Personality, 76, 1485 - 1522.

Labouvie, G. V. \& Baltes, P. B. (1973). Adolescent perception of adolescent change in personality and intelligence. Journal of Genetic Psychology, 122 (2), 17.

Levitas, R., Pantazis, C., Fahmy, E., Gordon, D., Lloyd, E. \& Patsios, D. (2007). The Multidimensional analysis of social exclusion. London: Department for Communities and Local Government.

Lynch, K. \& Baker, J. (2005). Equality in education: An equality of condition perspective. Theory and research in Education, 3, 131 - 163.

Markus, H. \& Nurius, P. (1986). Possible selves. American Psychologist, 41, 954 - 969. In S. Krauss Whitbourne (2005), Adult development \& aging: Biopsychological perspectives. Hoboken: John Wiley \& Sons, Inc., 259.

Martin, A. (2009). Digital Literacy for the Third Age: Sustaining Identity in an Uncertain World. eLearning Papers, 12,1 - 15.

Mastergeorge, A. M. (2001). Guided Participation in sociocultural learning: Intervention and apprenticeship. Academic Search Premier, 22 (1), 14.

McClusky, H., Y. (1970). A dynamic approach to participation in community development. Journal of Community Development Society, 1970, 1, 8.

Mouratidis, A., Vansteenkiste, M., Sideridis, G., \& Lens, W. (2011). Vitality and interest-enjoyment as a function of class-to-class variation in need-supportive teaching and pupils' autonomous motivation. Journal of Educational Psychology, 103, 353 - 366. 
Nilsson, A. (2010). Vocational education and training - an engine for economic growth and a vehicle for social inclusion? International Journal of Training and Development, 14 (4), 251 - 272.

Nye M. \& Hargreaves, T. (2009). Exploring the Social Dynamics of Proenvironmental Behavior Change: A Comparative Study of Intervention Processes at Home and Work. Journal of Industrial Ecology, vol. $14(1), 137$.

OECD (2006). Where immigrant students succeed. A comparative review of performance and engagement in PISA 2003. Paris: OECD Publishing.

Ogg, J. (2005). Social exclusion and insecurity among older Europeans: the influence of welfare regimes. Ageing \& Society, 25, 69.

Peters, S.J. (2004). Inclusive education: An EFA strategy for all children. Washington: The World Bank.

Popkewitz, T. \& Linblad, S. (2000). Educational Governance and Social Inclusion and Exclusion: Some conceptual difficulties and problematics in policy and research 1. Discourse: Studies in the Cultural Politics of Education, 21 (1), 5 - 44.

Preece, J. (2010). Response to Learning through Life: thematic area of poverty reduction. International Journal of Lifelong Education, vol. 29 (4), 475 - 485.

Priemus, H. (2005). Het spel en de knikkers: Fysieke en sociale pijler verbonden. Tijdschrift B\&G / Uitgave Bank Nederlandse Gemeenten en Vereniging van Nederlandse Gemeenten, 2005 (1), 5.

Pugh, K. J., \& Bergin, D. A. (2006). Motivational Influences on Transfer. Educational Psychologist, 41 (3), $147-160$.

Raemdonck, I. (2006). Self-directedness in learning and career processes: A study in lower-qualified employees in Flanders. Gent: Universiteit van Gent.

Raemdonck, I., De Grip, A., Segers, M. Thijssen, J. \& Valcke, M. (2008). Zelfsturing in leren en loopbaan als predictoren van employability bij laaggeschoolde werknemers. Gedrag en organisatie (21), 4.

Renshaw. P.D. (2003). Community and learning: Contradictions, dilemmas and prospects. Discourse: Studies in the Cultural Politics of Education 24, (3), 355 - 370.

Ryan, R. M. \& Deci E. L. (2000). Self-determination theory and the facilitation of intrinsic motivation, social development, and well-being. American Psychologist, vol. 55 (1), 11.

Santrock, J. W. (2008). Life-span development. New York: McGraw-Hill.

Scharf, T., Phillipson, C. \& Smith, A., E. (2005). Social exclusion of older people in deprived urban communities of England. European Journal of Ageing, 2, 76.

Serrano-García, I. \& Bond, M. A. (1994). Empowering the silent ranks: Introduction. American Journal of Community Psychology, 22 (4), 13.

Smith, M. K. (2007). Social capital. The encyclopedia of informal education, 2007. 26 - 07 - 2007. $<w w w . i n f e d . o r g /$ biblio/social_capital.htm>.

Sullivan, E. (2002). Social exclusion, social identity and social capital: Reuniting the global, the local and the personal. Discussion paper for the Conference de I'Association Internationale des Ecoles de Travail Social.

The World Bank. (2007). Social Exclusion and the EU's Social Inclusion Agenda: Paper Prepared for the EU8 Social Inclusion Study. Washington: The World Bank.

Tsakloglou, P. \& Papadopoulos, F. (2002). Aggregate level and determining factors of social exclusion in twelve European countries. Journal of European Social Policy 12 (3), 211 - 225. 
UNESCO (2009). Global report on adult learning and education. Hamburg: UNESCO Institute for Lifelong Learning.

UNICEF. (2008). The state of the world's children. New York: UNICEF.

Van Houten, D. (2008). Werken aan inclusie. Tijdschrift Sociale Interventie, 17 (3), 45 - 56.

Van Regenmortel, T. (2009). Empowerment als uitdagend kader voor social inclusie en moderne zorg. Journal of Social Intervention: Theory and Practice 18 (4), 22.

Verté, D., De Witte, N. \& De Donder, L. (2007). Schaakmat of aan zet? Monitor voor lokaal ouderenbeleid in Vlaanderen. Brugge: Uitgeverij Van den Broele.

Verté, D., Dury, S., De Donder, L., Buffel, T. \& De Witte, N. (2011). Doe mee! Over ouderen en maatschappelijke participatie. Brugge: Provinciebestuur van West-Vlaanderen.

Vos, M., De Vries, M. \& Duvekot, C. (2007). Handreiking Wmo en Laaggeletterdheid. Den Haag: Ministerie van VWS / VNG.

Weiner, G., Arnot, M. \& David, M. (1997). Is the future female?: female success, male disadvantage, and changing gender patterns in education. In: A.H. Halsey, H. Lauder, P. Brown \& A. Stuart Wells (Eds), Education: culture, economy and society. Oxford: Oxford University Press.

Whalgren, B. \& Geiger, T. (2010). Integration through adult and continuing education. Copenhagen: Nationalt Center for Kompetenceudvikling. 


\section{Chapter 5: Understanding the effects of training programs for vulnerable adults on social inclusion as part of continuing education}

Published as De Greef, M., Segers, M. \& Verté, D. (2012). Understanding the effects of training programs for vulnerable adults on social inclusion as part of continuing education. Studies in Continuing Education. DOI: 10.1080/0158037X.2012.664126.

\section{Abstract}

According to the increasing rates of unemployment and poverty a significant share of the European population can be considered at risk of social exclusion. In order to combat social exclusion adult education seemed to be a possible tool, which can increase social inclusion among adult learners. This study explores factors relating to training programs considered as adult and continuing education which enhance social inclusion for vulnerable adults and their life environment. The results indicate that after following the training programs as part of continuing learning, the participants show a significant increase in activation and internalisation as well as participation and connection (as processes of social inclusion). Moreover, non-parametric correlation analysis and logistical regression analysis shows that the training design feature transfer possibilities is significantly related to the increase of almost all social inclusion variables. Besides this direct surroundings and learning contents and activities only significantly relates to the increase of social inclusion variables of activation and internalisation and care to the social inclusion variables of participation and connection. 


\section{Background}

In contemporary European society $17 \%$ of the European population are still considered atrisk-of-poverty (Eurostat, 2010). To prevent an ongoing increase of poverty, the year 2010 has been designed as the "European year for combating poverty and social exclusion" (Grauman, 2010). Additionally the European Commission argues for the necessity of investment in efforts, resources and time to ensure that at least 20 million people will be removed from the risk of poverty and social exclusion by 2020 (Grauman, 2010). In this context poverty refers to the rate of social exclusion besides "economic marginalisation". To be more explicit, the reasons for being considered at risk of poverty differ per subgroup (De la Fuente Anuncibay, 2007).

Tsakloglou and Papadopoulos (2002) discern different subgroups of people at risk of poverty, based on factors like unemployment, low educational qualifications, lone parenthood, non EU-citizenship and bad health in combination with ageing. Firstly, the unemployed can be considered as people at risk of social exclusion or are "vulnerable adults", because they are excluded from the labour market (Whalgren and Geiger, 2010). Secondly a large group of persons with a low level of educational attainment risk social exclusion. According to UNICEF (2008) illiteracy is one of the most important problems of the industrialised countries due to the fact that $22 \%$ of the population is illiterate. Besides few educational qualifications, Bynner and Londra (2004) underline the importance of social support for young and lone parents, who risk social exclusion as well as exclusion from the labour market. Fourthly, according to Dahlstedt and Bevelander (2010) the group of immigrants experience differences in linguistic aspects, in cultural backgrounds and the distance between the country of origin and the new country. They also can be considered as vulnerable adults at risk of social exclusion. Comparably, a part of the elderly can be seen as the last group at risk of social exclusion, who risk health problems, socioeconomic inequality and rate of poverty (Dannefer, 2003).

Given the aforementioned characteristics of the targetgroup "vulnerable adults", investment in social inclusion of these adults seems to be a necessary action. Social inclusion refers to a process where individuals try to control and cope with resources and services, take part in society and its activities, connect to and have social relationships and feel included in the (local) area (The World Bank, 2007; Van Houten, 2008; Levitas et al., 2007; Ogg, 2005). Many authors have argued upon the core role of adult education to increase social inclusion of adults at-risk (e.g. Nilsson, 2010). However, to date, hardly any evidence is available on the quality of these adult education programs and continuing learning by vulnerable adults (Nilsson, 2010). Partridge (1999) and Nilsson (2010) argue that insights in the most important elements of the learning environment is needed to improve educational programs aiming to enhance social inclusion of adult learners. However, the first and most crucial question, which has been largely unanswered to date, is if learning environments for vulnerable adults increase their social inclusion. Secondly we would like to know which elements of the learning environment influence the increase of social inclusion. As a first 
step in answering this question, this present study aims to explore and describe the relationship between the learning environment (seen as a training design) and the enhancement of social inclusion of vulnerable adults.

\section{Training programs for enhancing social inclusion}

Training of adults and more precisely the question of how to enhance transfer of training is a topic that has received a lot of attention in the field of Human Resource Development (for recent review studies, see Aguinis and Kraiger, 2009; Cheng and Hampson, 2008; Holton, Chen and Naquin, 2003). Although in this field of study the outcomes of training has been mainly defined in terms of cognitive learning gains, improvement of job performance or positive impact on the organisation (return on investment), this strand of research offers relevant insights for our study targeting social inclusion as an outcome of training programs. Based on the pivotal work of Baldwin and Ford (1988) and more recent review studies (e.g. Cheng and Hampson, 2008; Cheng and Ho, 2001; Holton, Chen and Naquin, 2003; Nijhuis, Segers and Gijselaers, 2005 and Nijman, 2004), three groups of variables influencing training transfer and to build up a training design are discerned, namely: trainee characteristics, transfer design and work environment (in the context of this study defined as the social environment and life-circumstances of trainees). To be clear, the transfer design is part of the training design and refers to the supporting elements of the learning environment aiming to increase transfer. Regarding the HRD-research (Human Resource Development), the environment in which learned competencies should be used, can be supportive in applying these new competencies. Within our study, the environment refers to the environment in which new basic skills should be used, namely the daily life environment. To be more precise, in our study we need to address the daily life environment instead of the work environment. Imaginably this environment is more complex and it is therefore necessary to clearly describe and define the three elements of the training design.

\section{Trainee characteristics}

Given the context of the present study, training vulnerable adults to enhance social inclusion, we address the input variable "trainee characteristics" from a social inclusion perspective. As one of the few studies in the context of social inclusion, Verté et al. (2007) states the relevance of age, gender, number of children, marital status, level of training, prior education and courses, (un)employment and racial background. According to this study it is necessary to have insights into the socio-demographic factors in order to determine or exclude its influence on the increase of social inclusion. He argues that socio-demographic 
factors can be important for determining and blocking someone's societal development (Verté et al., 2007).

In addition, the study of Gegenfurtner (2011) among 31.718 participants underlines the influence of motivation on transfer. In this respect many authors refer to the relevance of the trainees' motivation to learn as the willingness of a learner to learn the contents of a training program (Noe and Schmitt, 1986; Cheng and Ho, 2001; Pham, Segers and Gijselaers, 2010). The researchers conclude that the motivation to learn, influences either the trainee's training performance or the transfer outcome (Cheng and Ho, 2001; Pugh and Bergin, 2006).

Finally in this study, we address the role of the trainee's self-directed learning. Although studies in the field of adult education (e.g. Knowles, 1975; Mezirow, 1997) have repeatedly stressed the importance of self-directed learning, there is hardly any evidence on the role of this variable in the transfer of training literature. Raemdonck (2006) explains self-directed learning as the ability of a learner to influence his or her learning processes in order to handle his or her own situation. It is a process that can be influenced by individual characteristics as well as the conditions of the surroundings. The results of her study indicate that self-directness among low qualified learners significantly influence the process of learning by low skilled employees. In the study presented here, $67 \%$ of the vulnerable adults (see table 1) went to school for merely 10 years or less and can be considered as low qualified learners, for whom self-directed learning can be hypothesized to be an important variable influencing the outcome of adult education programs in terms of social inclusion.

\section{Transfer design}

Researchers as Baldwin and Ford (1988) and more recent review studies (e.g. Cheng and Hampson, 2008; Cheng and Ho, 2001; Holton, Chen and Naquin, 2003; Nijhuis, Segers and Gijselaers, 2005; Nijman, 2004) indicate the significant influence of three elements of transfer design of a training program, namely learning contents and -activities, transfer climate (including the direct surroundings and transfer possibilities) and supervisor support. With respect to the latter, given the context of adult education programs aiming to enhance social inclusion (and not job performance), the role of the supervisor is not relevant. However, in this context, the teacher of the training programs does play an important role in supporting trainees to apply what they have learned in their daily life.

\subsection{Learning contents and -activities}

During the past ten years, the effectiveness of the design of training programs using the traditional design principles such as identical elements and over-learning (see e.g. Nijman et al., 2006) are under debate. Since the early 1990's the interest in constructivism as a 
learning theory has intensified. The core idea of constructivist pedagogy considers learning as meaning making and the negotiation of meaning. Given the changed educational approach in training programs, together with Pham, Gijselaers and Segers (2011) we claim that investigating the influence of training design on the transfer of training needs to take a constructivist perspective into account. Regarding the constructivist learning environments, authors have tried to describe its key features (e.g. Jonassen, 1994). Tenenbaum et al. (2001) discern seven components of constructivist teaching and learning. They argue the importance of supporting: (1) arguments, discussions and debates among learners, (2) conceptual conflicts and dilemmas, (3) the sharing of ideas with others, (4) the use of materials and measures targeted toward solutions, (5) the enhancement of the learners' reflections and concept investigation, in addition they stress the importance of (6) meeting the learners' learning needs and (7) making meaning by addressing real life examples during the instructional unit. The Tenenbaum et al. (2001) instrument, based on these components, has been used and validated in various studies in higher education (e.g. Gijbels, Segers and Struyf, 2008; Gijbels, Van de Watering, Dochy and Van den Bossche, 2006) as well as in the context of adult education (Pham, Segers and Gijselaers, 2011).

\subsection{Transfer climate}

Transfer climate refers to the factors in the environment of the trainee that may facilitate or inhibit the use of trained skills (Burke and Baldwin, 1999). Prior studies have indicated the relevance of different components of the transfer climate such as supervisor support, peer support, supervisor sanctions, positive and negative personal outcomes, sanctioning of transfer and resistance to change (e.g. Holton, Bates and Ruona, 2000; Rouiller and Goldstein, 1993). In the context of training programs aiming to enhance social inclusion, the transfer climate does not refer to the work environment but to the daily life environment; more precisely the family and the community where an individual belongs to. Therefore, supervisor support, generally referring to the extent to which supervisors reinforce and support employees by the transfer of training (e.g. Richman-Hirsch, 2001) is not relevant. This is also the case for supervisor sanctions. As a result, transfer climate consists of two elements, namely transfer possibilities (based on peer support) and direct surroundings (based on positive and negative personal outcomes, sanctioning of transfer and resistance to change).

\subsubsection{Transfer possibilities}

Firstly, opportunities to use training on the job is "the extent to which a trainee is provided with or actively obtains work experience relevant to the tasks for which he or she was trained" (Ford, Quinones, Sego and Speer Sorra 1992, p. 512). This factor is described as a multidimensional opportunity, suggesting a differentiation between the number of tasks and the type of tasks to be performed. Former research indicate that when trainees have fewer 
opportunities to use the training in the workplace, transfer is limited (e.g. Lim, Yoon and Morris, 2006). Moreover, other studies have shown the importance of these opportunities to transfer in terms of enhancing trainees' motivation to transfer (e.g. Seyler, et al., 1998).

Furthermore Pham, Gijselaers and Segers (2011) state that peer support refers to "the level to which peers behave producing reinforcement for trainees' transfer of training". Based on former research (e.g. Noe and Schmitt, 1986; Seyler et al., 1998), they conclude that peer support can affect trainees' motivation to transfer and predict opportunities to use new training content on the job. In the context of training programs for social inclusion, the opportunity to use refers to the extent to which the employed or unemployed trainee has the possibility to use the competencies acquired during education in his or her daily life. Supportive family and friends might influence trainees' possibilities to join education, apply what they have learned and to further practice and develop the competences acquired during the training program (Kilpatrick and Abbott-Chapman, 2002). In other words they are part of the realisation of the transfer possibilities.

\subsubsection{Direct surroundings}

Secondly, the transfer climate of the vulnerable adult refers to his or her direct surroundings influenced by positive and negative personal outcomes, sanctioning of transfer and resistance to change.

To be more precise, the "Personal Outcomes-Positive" means the rate in which joining training can lead to positive outcomes for the individual (Holton et al., 1997). Within jobrelated training programs, it is evidenced that the "Personal Outcomes-Positive" can influence transfer of training. Therefore it can be expected that if participants of adult education programs experience more social inclusion in their daily life, they will be encouraged to use more competences acquired during the training program.

On the other hand the "Personal Outcomes-Negative" refers to the negative consequence for trainees if they don't use the learned knowledge and skills after training on the job (Pham, Gijselaers and Segers, 2011). This implies that trainees risk a negative outcome (like being reprimanded or overlooked for a raise in income) if they do not use their new acquired knowledge or on-the-job skills. It can be expected that this would also be the case for adults participating in programs for social inclusion if they do not apply the learned competencies to improve their social inclusion in daily society.

Furthermore sanctioning of transfer refers to trainees perceiving negative response from others when transferring training (Holton, Bates and Ruona, 2000; Holton et al., 1997), in terms of punishment (Rouiller and Goldstein, 1993) or experiencing supervisors' indifference and active opposition and even being seen as outrageous by others (Russ-Eft, 2002). This might lead to reduced motivation of transfer (e.g. Seyler et al., 1998). Especially in the context of vulnerable adults applying new knowledge, skills and competences in order to improve their quality of daily life, being sanctioned to do so might have detrimental effects on their motivation to transfer. 
A similar aspect of transfer climate is "resistance to change" in the workplace, more specifically the extent to which individuals resist or discourage transfer of training (Holton, Bates and Ruona, 2000). Pham, Gijselaers and Segers (2011) state that trainees have to challenge the transfer of a training process. Previous studies clearly indicate that co-worker's openness to the changes, which a trainee induces in the workplace as a result of the newly acquired competences, will increase trainee motivation to transfer (Ruona et al., 2002) and transfer outcomes (Cheng, 2000). It might be expected that when vulnerable adults develop competences to cope with daily life and therefore make them more self-directed in life this may lead to a significant change in their relationships with family and friends. When these changes are not accepted, this might block the transfer of the newly learned competences. As a result, positive and negative personal outcomes, sanctioning of transfer and resistance to change form the direct surroundings for transfer.

\subsection{Teacher support}

Transfer of training literature has examined how teachers can support trainees for transfer using (Hutchins and Burke, 2006). Pratt (1998) states that the teacher should support the learning process of the adult learner in using the learned knowledge and skills among others by stimulating interaction between learner and teacher and facilitating a comfortable learning environment. More concretely, Nijman (2004) has evidenced the importance of instrumental support, informational support, appraisal support and emotional support. An instrumental approach refers to for example a teacher helping in the planning of using the learned contents in daily life; informational support implies that the teacher gives advice how to use what has been learned in daily life; appraisal support means for example that the teacher shows appraisal for changes in the learners' daily life as a result of the training; emotional support refers to the behaviour of the teacher such as telling the trainee that he or she can always count on the teacher when he or she experiences problems.

\subsection{Life-circumstances}

Former transfer of training studies have mainly focussed on the acquisition of job-related skills instead of the enhancement of social inclusion of the participants. Adult education programs enhancing social inclusion prepare learners to function in daily life. Consequently the work environment as a variable influencing transfer of training is irrelevant in the setting of training programs for social inclusion. Instead, participants' life-circumstances influencing social inclusion are more relevant. According to Andrews and Withey (1974) changes in the personal life of the participants can increase social inclusion. Hence Andrews and Withey (1974) and Liu (1974) underline the importance of the life environment for the improvement of social inclusion. 
The life environment of trainees refers to their personal life-circumstances. This refers to the circumstances in which they experience life and are satisfied with it, for example with their family life (Andrews and Withey, 1974). Trainees' life environment also includes how they deal with the raising of children, work and care. That is, how they can cope with the problems of raising children, challenges at work and if necessary the needed care for a relative or a friend (Andrews and Withey, 1974). According to Andrews and Withey (1974) these kind of life-circumstances are meaningful for improving or blocking the increase of social inclusion among vulnerable adults. Personal life-circumstances refers to good health, happiness and responsibility.

\section{Transfer effects in terms of increase of social inclusion}

Especially in the context of training programs for vulnerable adults, the impact of training on outcomes other than job performance is relevant. In this context, social inclusion serves as antecedent of job-related outcomes such as reintegration on the labour market. Accordingly outcomes of educational programs for vulnerable adults are not defined in terms of cognitive learning gains, job performance or employment, but in terms of social inclusion (Main, 1979; Solarczyk-Ambrozik, 1998).

According to Mastergeorge (2001), Guildford (2000), Fortuin and Keune (1997) and Verté et al. (2007) results of social inclusion can be defined as four different processes: activation, internalisation, participation and connection. These processes match the description of the construct social inclusion of Delors (1996): knowing more, being yourself, doing more and living together with others.

\subsection{Social inclusion as process of activation and internalisation}

According to Fortuin and Keune (1997) the increase of social inclusion implies the activation of vulnerable adults. This means that vulnerable adults are able to deal with daily affairs like being informed by media (TV, radio and internet) and organising their own finances. Fortuin and Keune (1997) indicate that activation refers to a good liveability in the direct surroundings instead of acquiring a new role in society or community. Likewise Movisie (2010) states that activation is a process of being able to function in society as an independent individual or as an independent wage earner to attain the basic needs of life. Besides the process of activation vulnerable adults want to be accepted in society in order to attain one's appropriate place in life (Guildford, 2000). Mastergeorge (2001) describes this in terms of a process of internalisation referring to being satisfied with oneself and being able to direct one's own life in a responsible and happy way. For example to have the courage to make own choices, being assertive or feeling safe in and around the house. In fact former research by Andrews and Withey (1974) and Liu (1974) underline the possibility of 
internalisation in different life domains as family life, health, housing and financial affairs (including technical development), economical status, cognitive satisfaction, psycho-social structures, affective happiness and the experience of a sense of belonging to society. The study of Andrews and Withey (1974) indicates that different life domains (domains influencing the satisfaction of people's lives, like family, money and religion) can influence the rate of social inclusion (especially by marginalised people).

\subsection{Social inclusion as process of participation and connection}

Though social inclusion basically seems to be an individual process, especially when defining it as activation and internalisation, improving social inclusion is also a process of meeting others and developing new social interactions (Verté et al., 2007). Colley (1975) and Huisman et al. (2003) define the process of gaining new social interactions as a process of connection.

Likewise participation is seen as a process of taking part in society (Guildford, 2000). Increase in participation means that people become active in doing things they did not undertake before. For example vulnerable adults taking part in official organisations, visit activities in the community or go out in the evening (Verté et al., 2007).

\section{Research goals and research questions}

This current study aims to take a first step in the development of a transfer of training model for training programs aiming to enhance social inclusion of vulnerable adults.

We would therefore like to find answers to two research questions, which are leading to this study, that is:

1. What is the specific outcome in terms of social inclusion among vulnerable adults after joining an adult education program?

2. What is the relationship between learning environment (seen as combination of lifecircumstances and transfer design) and increase of social inclusion among vulnerable adults?

\section{Methodology}

\subsection{Sample}

787 Learners (response rate of $67 \%$ ) returned the questionnaire at the beginning and 515 learners (response rate of $44 \%$ ) after the course. 
The participants in this study are adult learners following courses at adult education institutions. These adult learners followed three kinds of courses in order to increase social inclusion, namely language courses, basic skills courses and courses concerning digital competencies. The sample encompassed 100 courses, namely 24 language courses, 36 basic skills courses and 40 courses concerning digital competencies. All these courses are part of the Dutch national educational program aiming to increase social inclusion. The sample is stratified at random by 31 regional adult education centres (with 39 different locations). Every regional adult education centre is asked to involve two to four different training programs in this study. For each training program one teacher is involved. In order to involve enough participants for the study teachers are asked to hand over the questionnaires to their adult learners with a maximum of 30 participants per centre.

As presented in table 1 , the majority of the participants are female $(68.7 \%)$ and older than 41 years $(78.2 \%)$. Besides this most of the participants are autochthone $(81.8 \%)$ and married (64.4\%), have two children (42.6\%), attended school less than 10 years (76\%), are unemployed (50.2\%) and voluntarily attended the course (63.5\%).

Table 1: Respondents' background characteristics ( $N=787)$

\begin{tabular}{ll}
\hline Characteristic of respondent & $\begin{array}{l}\text { \% of the total group } \\
\text { of respondents }\end{array}$ \\
\hline Gender & 29.7 \\
Male & 68.7 \\
Female & \\
Nationality & 81.8 \\
Autochthonal & 15.8 \\
Foreign & \\
Age & 16.9 \\
$21-40$ & 32.9 \\
$41-60$ & 45.3 \\
$61-80$ & \\
Marital status & 64.4 \\
Married & 16.8 \\
Unmarried & 5.5 \\
Living together & 11.3 \\
Widowed & \\
Number of children & 15.2 \\
0 & 10.9 \\
1 & 42.6 \\
2 & 20.1 \\
3 & 6.4 \\
4 & \\
Highest level of education & 2.0 \\
Primary school & 12.7 \\
Secondary school & 3.0 \\
Further education on level of middle class & 28.2 \\
Higher education & 31.1 \\
University & 12.7 \\
Other school systems & \\
\hline & \\
\hline & \\
\hline & \\
\hline
\end{tabular}




\begin{tabular}{ll}
\hline Total years of education & 33.7 \\
$<5$ & 33.3 \\
$6-10$ & 21 \\
$11-15$ & 5.8 \\
$16-20$ & \\
Professional qualification & 60.5 \\
Yes & 34.3 \\
No & \\
In the past attended courses & 25.3 \\
In behalf of work & 14.1 \\
Outside work & 31.8 \\
Both in behalf of and outside work & 22.6 \\
None & \\
Job & 27.1 \\
Paid work & 14.5 \\
Voluntary work & 4.3 \\
Both paid and voluntary work & 50.2 \\
None & \\
Motivation to join program of adult education & 63.5 \\
Voluntary & 7.8 \\
Sent by official organisation & 2.9 \\
Sent by employer or colleague & 11.2 \\
Encouraged by member of family, friend or acquaintance & \\
\hline
\end{tabular}

Note: Missing values are excluded in percentage calculations.

\subsection{Procedure}

During a plenary session on each location, the teachers attended an instruction and training held by the researcher. Subsequently every teacher received a standardised written instruction for stratifying the low qualified learners. Accordingly the teachers handed over a questionnaire to the learners at the start of the course (pretest) and the end of the course (posttest).

For the pretest, data was collected on individual characteristics (socio-demographic factors, motivation and the trainees' self-directedness in learning orientation), the trainees' lifecircumstances (personal life-circumstances, barriers, upbringing \& work and care) and the two variables of social inclusion, namely "activation and internalisation" and "participation and connection". At the end of the course (posttest) data was gathered on the training design features (teacher support; learning content and -activities; transfer climate (transfer possibilities and direct surroundings and teacher support) besides the self-directedness in learning (as part of the trainee characteristics), the trainees' life-circumstances (personal lifecircumstances, barriers, upbringing \& work and care) and the two variables of social inclusion, namely "activation and internalisation" and "participation and connection". 


\subsection{Instruments}

In a prior study (De Greef, Segers and Verté, 2010) the SIT-instrument (Social Inclusion after Transfer) was developed and validated. The instrument consists of the following scales: self-directed learning, training design, life-circumstances, activation and internalisation and participation and connection. In table 2, denoting the variables addressed in this study, we present for each scale an example item and the Cronbach's Alpha coefficients indicating the reliability of each scale for the sample in this study.

Table 2: Questionnaires used in this study, scales, example items per scale and reliability coefficients $(\mathrm{N}=308)$

\begin{tabular}{|c|c|c|c|c|}
\hline Questionnaires & Scales & $\begin{array}{l}\mathbf{N} \text { of } \\
\text { items }\end{array}$ & $\begin{array}{l}\text { Example of items per } \\
\text { scale }\end{array}$ & Cronbach's Alpha \\
\hline 1. Self-directed learning & Self-directed learning & 14 & Taking initiative to learn & 0.899 \\
\hline \multirow[t]{4}{*}{ 2. Transfer design } & Teacher support & 8 & Appreciation of learner & 0.911 \\
\hline & Learning contents and -activities & 4 & $\begin{array}{l}\text { Practical demonstrations of } \\
\text { problem solving }\end{array}$ & 0.809 \\
\hline & Direct surroundings & 9 & Support of surroundings & 0.636 \\
\hline & Transfer possibilities & 3 & Increase of confidence & 0.772 \\
\hline \multirow[t]{4}{*}{ 3. Life-circumstances } & Personal life-circumstances & 12 & Happiness & 0.928 \\
\hline & Barriers & 4 & Feeling too old to learn & 0.754 \\
\hline & Upbringing and work & 3 & Raising own children & 0.553 \\
\hline & Care & 3 & $\begin{array}{l}\text { Taking care of disabled } \\
\text { persons }\end{array}$ & 0.592 \\
\hline \multirow[t]{7}{*}{ 4. Activation \& Internalisation } & National language skills & 9 & Being able to read & 0.921 \\
\hline & Digital skills & 3 & $\begin{array}{l}\text { Being able to use the } \\
\text { computer }\end{array}$ & 0.936 \\
\hline & International language skills & 3 & $\begin{array}{l}\text { Speaking different } \\
\text { languages }\end{array}$ & 0.889 \\
\hline & Assertiveness & 5 & $\begin{array}{l}\text { Being able to solve } \\
\text { problems }\end{array}$ & 0.894 \\
\hline & Labour- and upbringing skills & 4 & $\begin{array}{l}\text { Being able to solve } \\
\text { problems }\end{array}$ & 0.815 \\
\hline & $\begin{array}{l}\text { Voluntary work and neighbourhood } \\
\text { skills }\end{array}$ & 3 & Working as a volunteer & 0.673 \\
\hline & Contact skills & 7 & Respecting others & 0.881 \\
\hline \multirow[t]{7}{*}{ 5. Participation \& Connection } & Meeting and attempting & 4 & Meeting people & 0.819 \\
\hline & Meeting intimate contacts & 4 & Visiting family & 0.873 \\
\hline & $\begin{array}{l}\text { Attempting associations in } \\
\text { neighbourhood }\end{array}$ & 7 & $\begin{array}{l}\text { Organising activities in } \\
\text { neighbourhood }\end{array}$ & 0.847 \\
\hline & Being active in nature and sports & 4 & Enjoying sport activities & 0.613 \\
\hline & Involving into arts and culture & 2 & Enjoying the arts & 0.696 \\
\hline & Getting a membership & 4 & Member of a sports club & $0.572 *$ \\
\hline & Preventing loneliness & 11 & Example feeling empty & $0.800 *$ \\
\hline
\end{tabular}

Note 1: * Means that the items have a different scale, namely nominal and ordinal.

So this number reflects a Spearman Correlation. 
To confirm the construct validity of this instrument for the sample in this study, a Confirmatory Analysis (CFA) is conducted by using EQS 6.1 using maximum likehood estimation (Byrne, 2001). The goodness of fit indices of the final model indicates that the model fits the data very well. Concerning all the items of the factors (confirming the hypothetical factors) provide a good fit to the data with $\chi 2$ of 408.40 or more by $\mathrm{N}=787$, CFI between $0.884-0.937$, RMSEA varying $0.065-0.079$ and St RMR between $0.039-$ 0.069 (see table 3).

Table 3: Fit indices and correlations factors SIT-model

\begin{tabular}{llllll}
\hline Factors $\downarrow$ & $\chi \mathbf{2} / \mathbf{d f}$ & $\begin{array}{l}\text { ST. } \\
\text { RMR }\end{array}$ & CFI & RMSEA & $\alpha$ (PCA) \\
\hline Dependent factors & & & & & \\
Self-directed learning & 408.40 & 0.039 & 0.937 & 0.074 & 0.899 \\
$\begin{array}{l}\text { Transfer design } \\
\text { Life-circumstances }\end{array}$ & 700.34 & 0.069 & 0.900 & 0.079 & 0.906 \\
Independent factors & 578.82 & 0.056 & 0.900 & 0.065 & 0.783 \\
Activation \& Internalisation & & & & & \\
Participation \& Connection & 1820.70 & 0.052 & 0.912 & 0.079 & 0.954 \\
\hline
\end{tabular}

\subsection{Statistical analyses}

Regarding the variables of the scales activation and internalisation (national language skills, digital skills, international language skills, assertiveness, labour- and upbringing skills, voluntary work- and neighbourhood skills and contact skills) and participation and connection (meeting and attempting, meeting intimate contacts, attempting in associations in neighbourhood, being active in nature and sports, involving into arts and culture, getting a membership and preventing loneliness), a change-variable is constructed. This changevariable is calculated as the scores on the posttest minus the scores on the pretest. In order to determine the predictors of social inclusion, we conducted a non-parametric correlation analysis, more precisely a crosstab analysis. Furthermore logistical regression is used to acquire insight in the possible authentic influence of the variables of the training design on the increase of social inclusion.

\section{Results}

\subsection{Descriptives}

Tables $4 \mathrm{~A}$ and $4 \mathrm{~B}$ show the percentage of the participants experiencing increase as well as decrease of social inclusion. According to table $4 A 46.3 \%$ of the participants experience an increase of social inclusion on the subscale "activation and internalisation", besides $41.0 \%$ of the participants who experience an increase of social inclusion on the subscale "participation 
and connection". Furthermore the social inclusion variables show an increase varying from $21.8 \%$ ("getting a membership", defines as that one becomes a member of an association) to $54.7 \%$ ("digital language skills", defines as that one improves his or her digital competencies in working with a PC). Finally, the mean of change varies from 0.36 ("getting a membership") to 2.63 ("involving into arts and culture"). Accordingly most of the percentages of the population who experience an increase of social inclusion is less than $50 \%$.

Table 4A: Means and standard deviation of change in social inclusion variables for increase of social inclusion

\begin{tabular}{|c|c|c|c|c|c|c|c|}
\hline $\begin{array}{l}\text { Dependent variables of social } \\
\text { inclusion } \downarrow\end{array}$ & $\begin{array}{l}\text { Mean } \\
\text { To }\end{array}$ & SD TO & $\begin{array}{l}\text { Mean } \\
\text { T1 }\end{array}$ & SD T1 & $\begin{array}{l}\text { Mean of } \\
\text { change }\end{array}$ & $\begin{array}{l}\text { SD of } \\
\text { change }\end{array}$ & $\begin{array}{l}\text { \% of } \\
\text { population } \\
\text { experiencing } \\
\text { increase }\end{array}$ \\
\hline Activation and internalisation & 6.83 & 1.37 & 7.60 & 1.24 & 0.77 & 0.88 & 46.3 \\
\hline National language skills & 7.15 & 1.42 & 8.22 & 1.23 & 1.08 & 1.02 & 34.5 \\
\hline Digital skills & 5.03 & 2.23 & 7.55 & 1.98 & 2.52 & 2.01 & 54.7 \\
\hline International language skills & 4.70 & 2.58 & 6.73 & 2.35 & 2.03 & 1.53 & 45.2 \\
\hline Assertiveness & 6.70 & 1.67 & 7.99 & 1.38 & 1.29 & 1.29 & 40.9 \\
\hline Labour- and upbringing skills & 5.99 & 2.14 & 7.78 & 1.86 & 1.78 & 1.35 & 29.7 \\
\hline $\begin{array}{l}\text { Voluntary work- and neighbourhood } \\
\text { skills }\end{array}$ & 3.81 & 2.22 & 6.32 & 2.05 & 2.50 & 1.65 & 35.4 \\
\hline Contact skills & 7.12 & 1.73 & 8.30 & 1.34 & 1.18 & 1.18 & 35.3 \\
\hline Financial skills & 6.00 & 2.36 & 7.98 & 2.01 & 1.98 & 1.35 & 23.9 \\
\hline Participation and Connection & 4.03 & 1.00 & 4.30 & 1.14 & 0.64 & 0.61 & 41.0 \\
\hline $\begin{array}{l}\text { Attempting in associations and } \\
\text { neighbourhood }\end{array}$ & 3.06 & 2.06 & 4.77 & 2.34 & 1.71 & 1.25 & 41.4 \\
\hline Being active in nature and sports & 5.41 & 1.79 & 6.94 & 1.58 & 1.53 & 1.32 & 30.9 \\
\hline Involving into arts and culture & 3.98 & 2.06 & 6.60 & 1.82 & 2.63 & 1.68 & 29.3 \\
\hline Getting a membership & 1.23 & 0.26 & 1.60 & 0.30 & 0.36 & 0.22 & 21.8 \\
\hline Meeting and attempting & 5.91 & 1.90 & 7.66 & 1.60 & 1.75 & 1.58 & 32.4 \\
\hline Meeting intimate contacts & 7.24 & 1.36 & 8.27 & 1.16 & 1.02 & 1.06 & 36.4 \\
\hline Preventing loneliness & 2.25 & 0.52 & 2.62 & 0.39 & 0.37 & 0.36 & 44.3 \\
\hline
\end{tabular}


Table 4B: Means and standard deviation of change in social inclusion variables for stabilisation or decrease of social inclusion

\begin{tabular}{|c|c|c|c|c|c|c|c|}
\hline $\begin{array}{l}\text { Dependent variables of social } \\
\text { inclusion } \downarrow\end{array}$ & $\begin{array}{l}\text { Mean } \\
\text { To }\end{array}$ & SD TO & $\begin{array}{l}\text { Mean } \\
\text { T1 }\end{array}$ & SD T1 & $\begin{array}{l}\text { Mean of } \\
\text { change }\end{array}$ & $\begin{array}{l}\text { SD of } \\
\text { change }\end{array}$ & $\begin{array}{l}\text { \% of } \\
\text { population } \\
\text { experiencing } \\
\text { stabilisation } \\
\text { or decrease }\end{array}$ \\
\hline Activation and internalisation & 7.20 & 1.19 & 5.28 & 2.36 & -1.92 & 2.11 & 53.7 \\
\hline National language skills & 8.41 & 2.18 & 6.73 & 2.71 & -1.70 & 2.44 & 65.5 \\
\hline Digital skills & 7.84 & 2.38 & 6.20 & 3.23 & -1.64 & 2.50 & 45.3 \\
\hline International language skills & 6.56 & 2.53 & 4.54 & 3.05 & -2.02 & 2.29 & 54.8 \\
\hline Assertiveness & 7.81 & 1.25 & 5.77 & 2.67 & -2.05 & 2.54 & 59.1 \\
\hline Labour- and upbringing skills & 6.57 & 2.72 & 4.34 & 3.09 & -2.22 & 2.53 & 70.3 \\
\hline $\begin{array}{l}\text { Voluntary work- and neighbourhood } \\
\text { skills }\end{array}$ & 4.41 & 2.61 & 2.84 & 2.28 & -1.58 & 1.96 & 64.6 \\
\hline Contact skills & 8.08 & 1.23 & 5.74 & 3.03 & -2.34 & 2.74 & 64.7 \\
\hline Financial skills & 8.44 & 1.57 & 6.40 & 3.20 & -2.05 & 2.90 & 76.1 \\
\hline Participation and Connection & 4.30 & 0.93 & 3.43 & 1.39 & -1.08 & 1.13 & 59.0 \\
\hline $\begin{array}{l}\text { Attempting in associations and } \\
\text { neighbourhood }\end{array}$ & 3.35 & 2.39 & 2.16 & 2.00 & -1.20 & 1.65 & 58.6 \\
\hline Being active in nature and sports & 7.23 & 1.90 & 5.22 & 2.90 & -2.01 & 2.41 & 69.1 \\
\hline Involving into arts and culture & 4.99 & 3.00 & 3.29 & 2.90 & -1.70 & 2.08 & 70.7 \\
\hline Getting a membership & 1.39 & 0.32 & 1.24 & 0.29 & -0.15 & 0.26 & 78.2 \\
\hline Meeting and attempting & 7.79 & 1.68 & 5.58 & 2.87 & -2.21 & 2.41 & 67.6 \\
\hline Meeting intimate contacts & 8.48 & 1.22 & 6.64 & 2.84 & -1.84 & 2.50 & 63.6 \\
\hline Preventing loneliness & 2.66 & 0.43 & 2.52 & 0.47 & -0.14 & 0.18 & 55.7 \\
\hline
\end{tabular}

\subsection{Correlations}

Table 5 gives an overview of the correlations between the independent variables of the training design and the constructs of the social inclusion variables among participants who experience an increase of social inclusion. With respect to "activation and internalisation", Spearman's Rho Correlations indices show that three training design variables are significantly correlated (weak to moderate) to more than three variables. More precisely, "teacher support" is significantly correlated with "national language skills", "international language skills", "assertiveness", "voluntary work and neighbourhood skills", contact skills and "financial skills" (see table 5). Moreover, "learning contents and -activities" are training design variables, which are associated with the variables "national language skills", "international language skills", "assertiveness", "labour- and upbringing skills" and contact skills (see table 5). Besides this according to table 5, the extent to which a program offers transfer possibilities is significantly related to "national language skills", "digital skills", "international language skills", "assertiveness", "labour- and upbringing skills", "voluntary work and neighbourhood skills" and "financial skills". 
According to the Spearman Rho Correlations the same three training design variables are significantly correlated (weak to moderate) to more than three social inclusion variables of "activation and internalisation", as well as the social inclusion variables of "participation and connection". Referring to "teacher support" this variable is significantly correlated to "attempting in associations and neighbourhood", "being active in nature and sports", "meeting and attempting", "meeting intimate contacts" and "preventing loneliness" (see table 5). Furthermore table 5 shows that the same social inclusion variables of "participation and connection" are correlated to "teacher support" as well as to "learning contents and activities. At last "transfer possibilities" seems to be significantly correlated to "attempting in associations and neighbourhood", "being active in nature and sports", "involving into arts and culture", getting a membership" and "meeting intimate contacts" (see table 5). Finally correlations of one training design variable was significantly negative, namely between "direct surroundings" and "national language skills", "international language skills" and "attempting in associations and neighbourhood". This training design variable refers to the barriers, which one can experience during learning. According to the negative correlation it means if one experiences more barriers during learning in his or her direct surroundings the rate of increase on a social inclusion variable will be lower. 


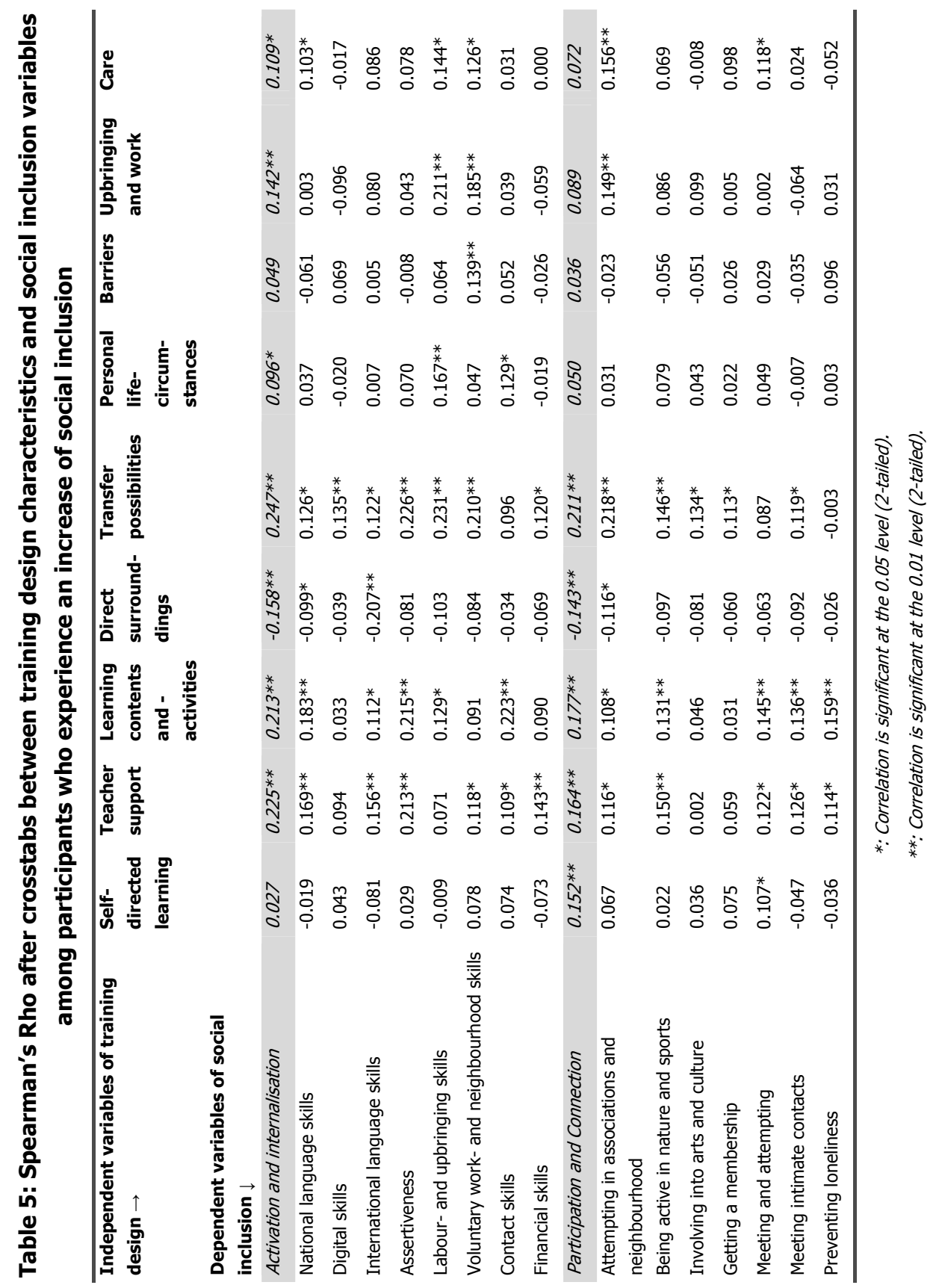




\subsection{Logistical regression}

The predictors on the social inclusion variables of "activation and internalisation" and "participation and connection" (for the participants who experienced an increase of social inclusion) were tested by logistical regression analysis (see tables $6 \mathrm{~A}$ and $6 \mathrm{~B}$ ). In the first place according to the model chi-square statistic the 7 models of the social inclusion variables of "activation and internalisation" and "participation and connection" are significant at the 0.01 level (see table 6A and 6B).

Firstly according to table $6 \mathrm{~A}$ the social inclusion variables of "activation and connection" classified $58.4 \%$ to $74.9 \%$ of the vulnerable adults correctly (Nagelkerke R2 varies from 0.033 to 0.143 ). In other words for $58.4 \%$ to $74.9 \%$ of the vulnerable adults the social inclusion variables predicted correctly, which features of the training design influenced the increase of activation and internalisation (depending on the different variables). Mostly the variable "transfer possibilities" is a significant predictor $(p<0.01)$, namely for the variables "digital skills" (0.116), "assertiveness" (0.158), "labour- and upbringing skills" (0.161) and "voluntary work and neighbourhood skills" (0.183). Besides this table 6A shows that the variable "upbringing and work" plays a significant role $(p<0.01)$ for "labour- and upbringing skills" (0.161) and "voluntary work and neighbourhood skills" (0.124) and the variable "learning contents and -activities" plays a significant role for "contact skills" (0.361). At last the training design variable "direct surroundings" seems to be a significant predictor ( $p<$ $0.01)$ for the variable "international language skills" (-0.225).

The results of the regression analysis indicate that experiencing more transfer possibilities predicts an increase of most social inclusion variables related to "activation and internalisation", namely on "digital skills", "assertiveness", "labour- and upbringing skills" and "voluntary work and neighbourhood skills". This means that if one has more opportunities to use what he or she has learned in daily practice one is for example more capable of using a PC, making his or her decisions, raise his or her children and doing voluntary work.

Furthermore if the learning contents and -activities is based on a constructive perspective (for example discussing, reflecting and using meaningful daily life-examples) participants report an increase in their contact skills. Besides this, the learners' international language skills are affected if they experience support by their direct surroundings. At last the increase of participants' "labour- and upbringing skills" is affected by their work-situation and their possibilities to raise children.

Likewise the variable "transfer possibilities" seems to have a significant relation $(p<0.01)$ with the variables "attempting in associations and neighbourhood" (0.155), "involving into arts and culture" (0.127), "getting a membership" (0.118) belonging to the social inclusion variables of "participation and connection". In other words if a vulnerable adult has more transfer possibilities the increase of his or her attempts of being involved in associations and neighbourhood will be higher, his or her involvement into arts and culture will be higher and he or she will become a member of more or new local organisations. Furthermore the 
relation between "transfer possibilities" and "being active in nature and sports" (0.105) seems to be close to significant (see table 6B). At last the training design variable "care" plays a significant role $(p<0.01)$ for "attempting in associations and neighbourhood" (0.134). This means that if one is taking care of a relative or a friend he or she will be more involved in associations and neighbourhoods. Furthermore $60.1 \%$ to $78.4 \%$ of the vulnerable adults are classified correctly (Nagelkerke R2 varies from 0.027 to 0.134 ). This indicates that for $60.1 \%$ to $78.4 \%$ of the vulnerable adults the 7 models predicted correctly, which feature of the training design influenced the increase of participation and connection (depending on the different variables). 


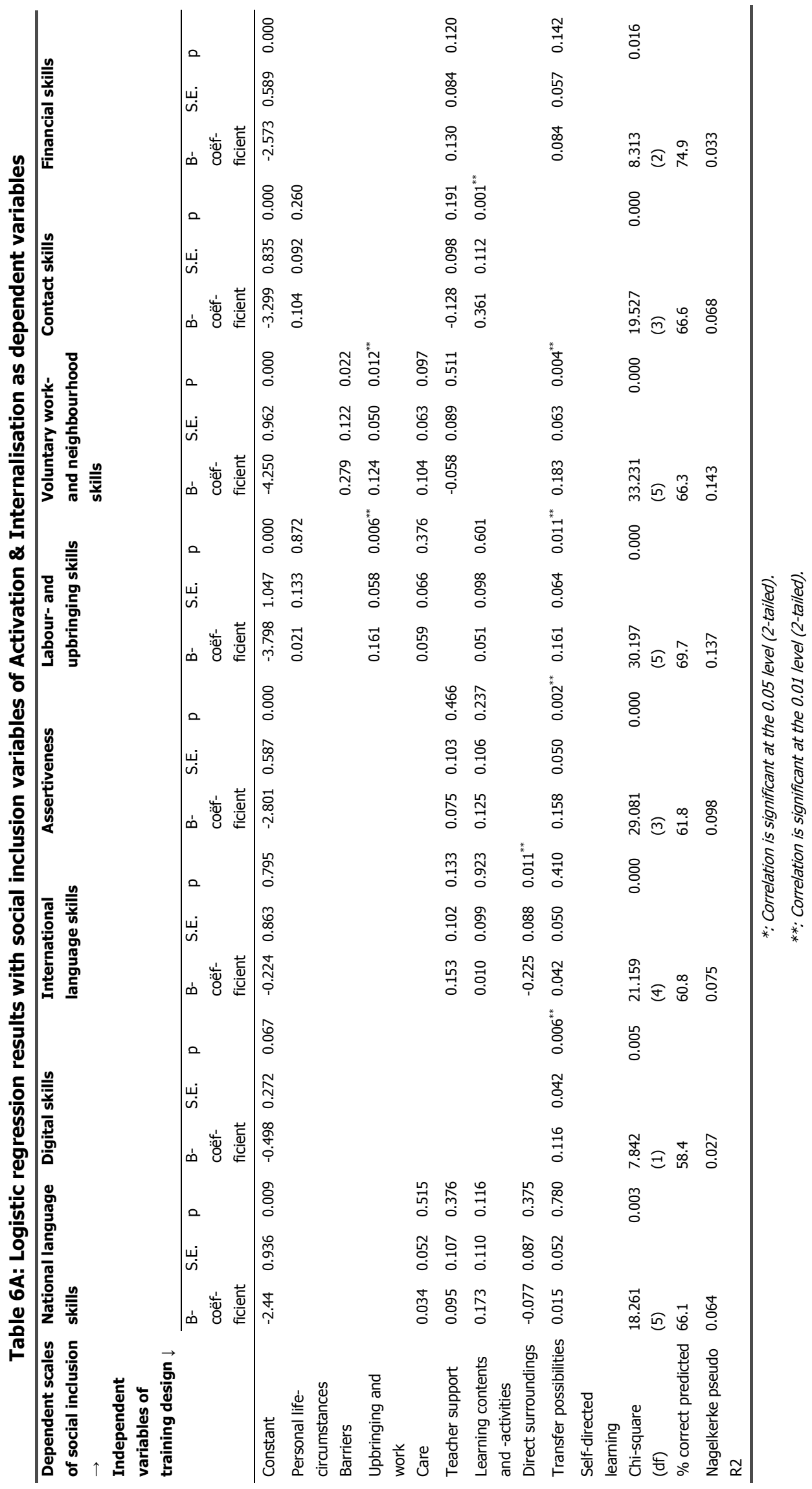




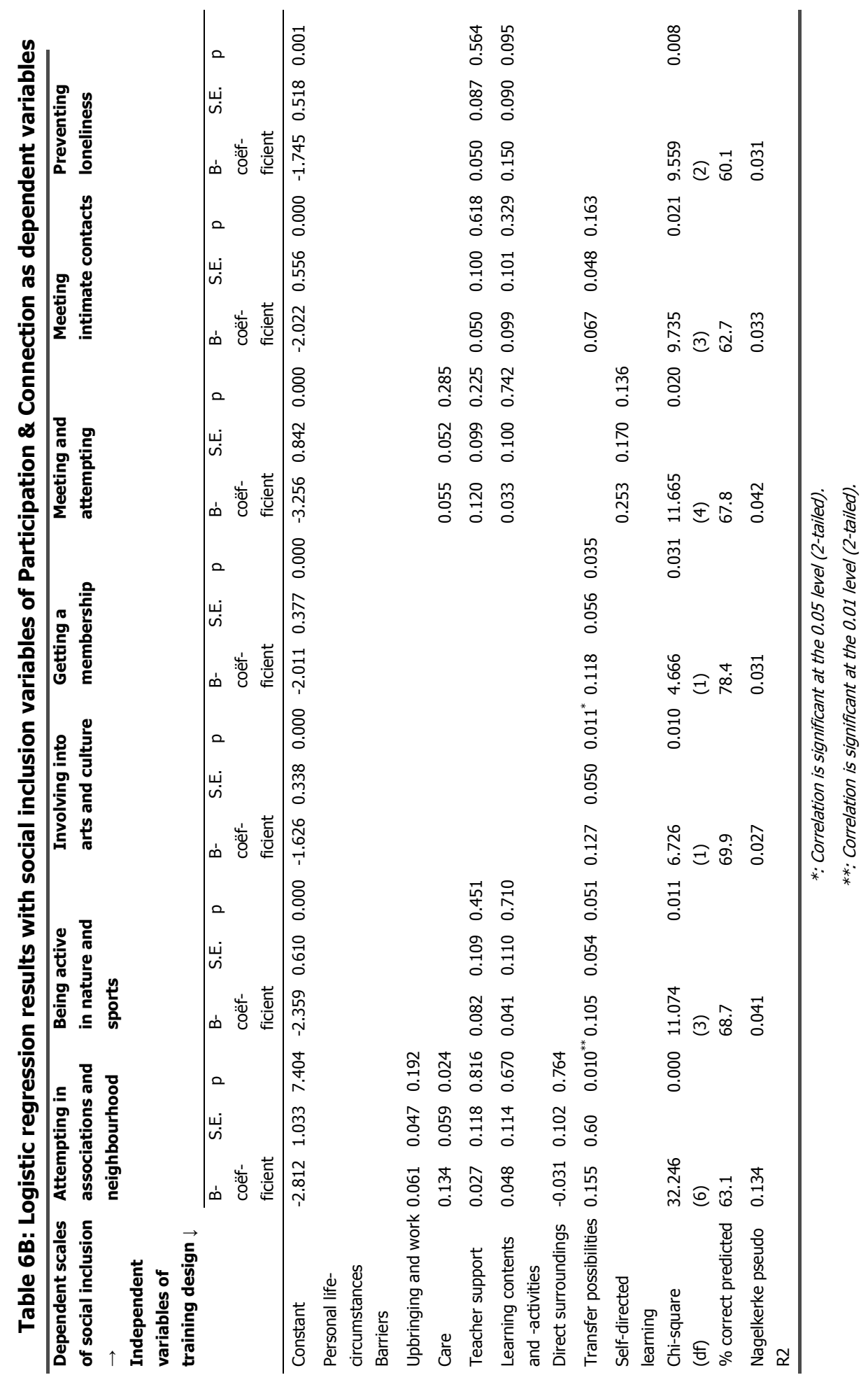




\section{Conclusions and discussion}

Regarding the use of education as part of continuing education, the training should be aiming the increase of social inclusion (Main, 1979; Solarczyk-Ambrozik, 1998) and the decrease of marginalisation (McClusky, 1970) to empower vulnerable adults according to Serrano-García and Bond (1994). As follows, vulnerable adults are thus more likely to enter the labour market after following the training. Therefore by using the SIT-model (based on HRD-research) substantive research has been conducted among vulnerable adults of courses of adult education to explore the relationship between the courses and the increase of social inclusion.

Firstly, some participants experience increase of social inclusion after following the training varying from $21.8 \%$ till $54.7 \%$ of the participants on the different constructs of social inclusion. After following courses for vulnerable adults, almost half of the participants (46.3\%) experienced an increase of activation as well as an increase of internalisation. Furthermore $41 \%$ of the participants participate more in society and have more connections with others.

Secondly the correlation and logistical regression between the features of the training design and the processes of social inclusion give insight in the influence of "self-directed learning", "teacher support", "learning contents and -activities", "direct surroundings", "transfer possibilities", "personal life-circumstances", "barriers", "upbringing and work" and "care" on the increase of social inclusion. According to logistical regression, the variable "transfer possibilities" seems to have the most impact on the variables of social inclusion, namely on "digital skills", "assertiveness", "labour- and upbringing skills", "voluntary work and neighbourhood skills", "attempting in associations and neighbourhood", "involving into arts and culture" and "getting a membership". This means that a person has more opportunities to use what he or she has learned in daily practice, for example in using the PC, solving personal problems and taking part in arts and culture. Besides this the variable "upbringing and work" seems to have an impact on "labour- and upbringing skills" and "voluntary work and neighbourhood skills" and the "learning contents and -activities" on "contact skills". Furthermore it is clear that if one experiences fewer barriers in the direct surroundings, the increase of the "international language skills" will be higher. Finally, if a learner takes care of one or more persons in his or her direct surroundings they seem to be more active within the community.

Consequently, the extent to which a training program offers transfer possibilities suggests to be most important for the increase of several variables of social inclusion. Besides this there are four other factors of the training design, which can influence the increase of social inclusion of vulnerable adults, to be mentioned: the trainees' situation of work in combination with his or her possibilities to raise children, the trainees' experienced barriers in the direct surroundings, the learning contents and -activities and the trainees' position in 
taking care of a relative or a friend. These factors have less impact on the increase of social inclusion than transfer possibilities. According to Nagelkerke R2 the elements of the training design influence the goals of the adult education programs, namely increase of social inclusion, like learning "national language skills" and increase of "labour- and upbringing skills", "voluntary work and neighbourhood skills" and "attempting in associations and neighbourhood".

Nonetheless, several limitations of the study have to be considered. First of all an in-depth study of the meaning of the increase of social inclusion is needed. This study can explore the perceptions of vulnerable adults in order to define more detailed constructs of social inclusion. For example none of the training design features plays a significant role in influencing the increase of "preventing loneliness", "meeting and attempting" and "meeting intimate contacts". Based on our literature review we expect the contrary. Therefore an indepth study is necessary. Concerning this in-depth study, phenomenographical research is one of the possibilities to discern the experienced phenomena of social inclusion influenced by the training design (Tan, 2008).

Secondly more insight and comparison of subgroups is needed to explain the authentic influence of each of the variables of training design on the constructs of social inclusion. For example increase of social inclusion can differ for participants with a low rate of self-directed learning from participants with a high rate of self-directed learning. In order to describe unique results for these groups this in-depth study can provide detailed information for adaptation of courses by vulnerable adults.

As a result we might suppose that this study shows that a new way of continuing education for vulnerable adults could be used to decrease social exclusion. But we should be careful with the interpretation of our results. This research shows the results of the participants experiencing increase of social inclusion after joining continuing education, but further research has to show if increase in social inclusion might mean an increase in socioeconomic value for our society, besides other benefits like lower societal costs and a better health as defined in the research among illiterate people (as a subgroup of vulnerable adults) of Groot and Maassen van den Brink (2006). The results of our research underline the importance of continuing education in obtaining personal skills in order to encounter social exclusion, but a next step has to be made to see if increase in social inclusion after joining continuing education can influence the qualification for the "economical marginalisation" in our society. 


\section{References}

Aguinis, H., \& Kraiger, K. (2009). Benefits of training and development for individuals and teams, organizations, and society. Annual Review of Psychology, 60, 451 - 474.

Andrews, F. M. \& Withey, S. B. (1974). Developing measures of perceived life quality: Results from several national surveys. Social Indicators Research, 1974 (1), 26.

Baldwin, T. T. \& Ford, K. J. (1988). Transfer of training: A review and directions for future research. Personnel Psychology, 1988 (41), 43.

Burke, L.A., \& Baldwin, T.T. (1999). Workforce training transfer: A study of the effect of relapse prevention training and transfer climate. Human Resource Management, 38 (3), 227 - 242.

Bynner, J. \& Londra, M. (2004). The impact of government policy on social exclusion among young people. London: The Office of the Deputy Prime Minister.

Byrne, B. M. (2001). Structural equation modeling with AMOS: Basic concepts, applications, and programming. Mahwah, NJ: Erlbaum.

Cheng, E. (2000). Test of the MBA knowledge and skills transfer. International Journal of Human resource Management, 11 (4), 837 - 852.

Cheng, E. W. L. \& Hampson, I. (2008). Transfer of training: A review and new insights. International Journal of Management Reviews 10, (4), 15.

Cheng, E. W. L. \& Ho, D.C.K. (2001). A review of transfer of training studies in the past decade. Personne/ Review, 30 (1), 17.

Colley, D. G. (1975). A social change index - an objective means to discern and measure the relative current social condition of cities, towns, and their sub-communities. Social Indicators Research, 1975 (1), 26.

Dahlstedt, I. \& Bevelander, P. (2010). General versus vocational education and employment integration of immigrants in Sweden. Journal of Immigrant and Refugee Studies, 8 (2), 158 - 193.

Dannefer, D. (2003). Cumulative Advantage / Disadvantage and the Life Course: Cross-Fertilizing Age and Social Science Theory. Journal of Gerontology: Social Sciences 58B (6), 327 - 337.

De Greef, M., Segers, M. \& Verté, D. (2010). Development of the SIT, an instrument to evaluate the transfer effects of adult education programs for social inclusion. Studies in Educational Evaluation (36), $42-61$.

De la Fuente Anuncibay, R. (2007). Social, personal and educational constraints on access to employment among groups at risk of social exclusion: contributions from an employment observatory. Journal of Vocational Education and Training, 59 (4), 435 - 449.

Delors, J. (1996). The four pillars of education. In Jarvis, P. \& Griffin, P., Adult and Continuing Education: Major themes in education. London: Routledge, 304 - 313.

Eurostat (2010). Combating poverty and social exclusion. Luxembourg: European Union.

Ford, J.K., Quinones, M. A., Sego, D. J. \& Speer Sorra, J. (1992). Factors affecting the opportunity to perform trained tasks on jobs. Personnel Psychology, 45 (3), 512.

Fortuin, K. \& Keune, C. (1997). Anders praten over jeugd: Naar een begrippenkader voor preventief jeugdbeleid. Utrecht: Verwey-Jonker Instituut. 
Gegenfurtner, A. (2011). Motivation and transfer in professional training: A meta-analysis of the moderating effects of knowledge type, instruction, and assessment conditions. Educational Research Review 6, $153-168$.

Gijbels, D., Segers, M., \& Struyf, E. (2008). Constructivist learning environments and the (im)possibility to change students' perceptions of assessment demands and approaches to learning. Instructional Science, 36, 431 - 443.

Gijbels, D., Van de Watering, G., \& Dochy, F, Van den Bossche, P. (2006). New learning environments and constructivism: The students' perspective. Instructional Science 34 (3), 213 - 226.

Grauman, B. (2010). Getting out of poverty. Luxembourg: European Commission.

Groot, W \& Maassen van den Brink, H. (2006). Stil vermogen, een onderzoek naar de maatschappelijke kosten van laaggeletterdheid. Den Haag: Stichting Lezen \& Schrijven.

Guildford, J. (2000). Making the case for social and economic inclusion. Canada Atlantic Region: Population and Public Health Branch.

Holton, E.F., Bates, R.A., \& Ruona, W.E.A. (2000). Development and construct validation of a generalized learning transfer system inventory. Human Resource Development Quarterly, 11 (4), 333 - 360.

Holton, E. F., Bates, R., Seyler, D., \& Carvalho, M. (1997) Toward construct validation of a transfer climate instrument. Human Resource Development Quarterly, 8, 110.

Holton, E. F., Chen H. \& Naquin, S. S. (2003). An examination of learning transfer system characteristics across organizational settings. Human Resource Development Quarterly, vol. 14 (4), 24.

Huisman, J., Pijls, T., Van Hoeij, J., Van Voorst van Beest, K., Boonaerts, Y. \& Lens, M. (2003). Portfolio sociale competenties: Primair onderwijs, vmbo, mbo. 's-Hertogenbosch: CINOP.

Hutchins, H. M. \& Burke, L. A. (2006). Has relapse prevention received a fair shake? A review and implications for future transfer research. Human Resource Development Review, 5 (1), 8 - 25.

Jonassen, D.H. (1994). Thinking Technology: toward a constructivist design model. Educational Technology, April, 34 - 37.

Kilpatrick, S. \& Abbott-Chapman, J. (2002). Rural young peoples' work/study priorities and aspirations: The influence of social capital. Australian Education Researcher, 29 (1), 43 - 68.

Knowles, M. S. (1975). Self-directed learning: A guide for learners and teachers. New York: Association Press.

Levitas, R., Pantazis, C., Fahmy, E., Gordon, D., Lloyd, E. \& Patsios, D. (2007). The Multidimensional analysis of social exclusion. London: Department for Communities and Local Government.

Lim, D. H., Yoon, S. W., \& Morris, M. L. (2006). Combined effect of instructional and learner variables on course outcomes within an online learning environment. Journal of Interactive Online Learning, 5 (3), 255 - 269.

Liu, B. (1974). Quality of life indicators: a preliminary investigation. Social Indicators Research, 1 (22), 187 - 208.

Main, M. (1979). Social and personality-development. Contemporary Psychology, 24 (8), 11.

Mastergeorge, A. M. (2001). Guided Participation in sociocultural learning: Intervention and apprenticeship. Academic Search Premier, 22 (1), 14.

McClusky, H., Y. (1970). A dynamic approach to participation in community development. Journal of Community Development Society, 1970, 1, 8. 
Mezirow, J. (1997). Transformative Learning: Theory to Practice. In: Transformative learning in action: insights from practice. New directions for adult and continuing education, 74, 5 - 12.

Movisie (2010). Activering, 2010. 20 - 3 - 2010.

<http://www.movisie.nl/125241/def/home_/activering/wat_is_activering/activering/>.

Nijhuis, J. F. H., Segers, M. S. R. \& Gijselaers, W. H. (2005). Influence of redesigning a learning environment on student perceptions and learning strategies. Learning Environments Research, 2005 (8), 27.

Nijman, D.J.J.M. (2004). Supporting Transfer of Training: Effects of the Supervisor. Enschede: Universiteit Twente.

Nijman, D.J.J.M., Nijhof, W.J., Wognum, A.A.M., \& Veldkamp, B.P. (2006). Exploring differential effects of supervisor support on transfer of training. Journal of European Industrial Training, 30, 529 - 549.

Nilsson, A. (2010). Vocational education and training - an engine for economic growth and a vehicle for social inclusion? International Journal of Training and Development, 14 (4), 251 - 272.

Noe, R. A., \& Schmitt, N. (1986). The influence of trainee attitudes on training effectiveness: Test of a model. Personnel Psychology, 39, 497 - 523.

Ogg, J. (2005). Social exclusion and insecurity among older Europeans: the influence of welfare regimes. Ageing \& Society, 25, 69.

Partridge, M. (1999). Monitoring Adult Education: Monitoring adult education for knowledge-based policymaking. Hamburg: Druckerei Seemann.

Pham, N.T.P., Gijselaers, W.H. \& Segers, M.S. (2011). The Effect of the Trainees' Perception of the Training Design on Transfer of Training: The Case of MBA Programs in Vietnam. In: Van den Bossche, P., Gijselaers, W.H. \& Milter, R.G. (Eds), Building Learning Experiences in a Changing World. Advances in Business Education and Training. Dordrecht: Springer, Volume 3, 215 - 233.

Pham, N., Segers, M. S. R. \& Gijselaers, W. H. (2010). The effect of the trainees' perception of the training design on transfer of training. Deventer: Kluwer.

Pratt, D. D. (1998). Five perspectives on teaching in adult and higher education. Malabar, Florida: Krieger Publishing Company.

Pugh, K. J., \& Bergin, D. A. (2006). Motivational Influences on Transfer. Educational Psychologist, 41 (3), $147-160$.

Raemdonck, I. (2006). Self-directedness in learning and career processes: A study in lower-qualified employees in Flanders. Gent: Universiteit van Gent.

Richman-Hirsch, W.L. (2001). Posttraining Interventions to Enhance Transfer: The Moderating Effects of Work Environments. Human Resource Development Quarterly, 12 (2), 105 - 120.

Rouiller, J.Z. \& Goldstein, I.L. (1993). The relationship between organizational transfer climate and positive transfer training. Human Resource Development Quarterly, 4 (4), 377 - 390.

Ruona, W.E.A., Leimbach, M., Holton, E.F.I. \& Bates, R.A. (2002). The relationship between learner utility reactions and predicted learning transfer among trainees. International Journal of Training and Development, 6 (4), 218 - 228.

Russ-Eft, D. (2002). A typology of training design and work environment factors affecting workplace learning and transfer. Human Resource Development Review, 1, 45 - 65. 
Serrano-García, I. \& Bond, M. A. (1994). Empowering the silent ranks: Introduction. American Journal of Community Psychology, 22 (4), 13.

Seyler, D. L., Holton, E. F. III, Bates, R., Burnett, M. F., \& Carvalho, M. A. (1998). Factors affecting motivation to transfer training. International Journal of Training and Development, 2 (1), 2 - 16.

Solarczyk-Ambrozik, E. (19). Socio-economic transformation and adult learning in Poland. In Bisovsky, G., Bourgeois, E., Bron, M., Chivers, G. \& Larsson, S., Adult learning and social participation. Wien: Verband Wiener Volksbildung, 373 - 385.

Tan, K.H.K. (2008). Qualitatively different ways of experiencing student self-assessment. Higher Education Research \& Development, vol. 27 (1), 15 - 29.

Tenenbaum, G., Naidu, S., Olugbemiro, J. \& Austin, J. (2001). Constructivist pedagogy in conventional on campus and distance learning practice: An exploratory investigation. Learning and construction 11, $87-111$.

The World Bank. (2007). Social Exclusion and the EU's Social Inclusion Agenda: Paper Prepared for the EU8 Social Inclusion Study. Washington: The World Bank.

Tsakloglou, P. \& Papadopoulos, F. (2002). Aggregate level and determining factors of social exclusion in twelve European countries. Journal of European Social Policy 12 (3), 211 - 225.

UNICEF. (2008). The state of the world's children. New York: UNICEF.

Van Houten, D. (2008). Werken aan inclusie. Tijdschrift Sociale Interventie, 17 (3), 45 - 56.

Verté, D., De Witte, N. \& De Donder, L. (2007). Schaakmat of aan zet? Monitor voor lokaal ouderenbeleid in Vlaanderen. Brugge: Uitgeverij Van den Broele.

Whalgren, B. \& Geiger, T. (2010). Integration through adult and continuing education. Copenhagen: Nationalt Center for Kompetenceudvikling. 



\section{Chapter 6: General conclusions and discussion}

Based upon De Greef, M., Segers, M. \& Verté, D. (2012). The Impact of lifelong learning programs on social inclusion among vulnerable adults. Lifelong Learning in Europe. Vol. XVII, Issue 1.

Abstract

A significant share of our European population can be considered at-risk of poverty and social exclusion. In this context the importance of the pivotal role of education in increasing quality of life, to which Kumpalainen (2010b) refers in LLinE, is essential. Adult education can be a lever for increase of social inclusion among vulnerable adults. To date hardly any evidence is available concerning the outcome of adult education in terms of increase of social inclusion. In this article we present the most striking results of a series of studies concerning the outcome of lifelong learning programs among vulnerable adults in terms of increase of social inclusion and the significant contribution of the key elements of the learning environment. It aims to present a comprehensive overview of the results on increase of social inclusion besides the influentials of the learning environment and the trainee characteristics. It is obvious that some learners undergo a "transition" to better social inclusion after joining these programs. Especially on four conceptions of social inclusion, namely activation, internalisation, participation and connection (De Greef, Verté and Segers, 2012). But the rate of learners (experiencing this increase) is still circa half of the total population of learners. Furthermore the research results underline the importance of the variable transfer possibilities influencing the learning success among these learners. But further analysis according trainee characteristics show that not only elements of the learning environment influence the rate of increase of social inclusion. More concrete especially foreign learners and people who live together without being married experience a higher rate of increase on several variables of social inclusion. 


\section{Background}

A significant share of our European population can be considered at-risk of poverty and social exclusion. For example regarding to Eurostat (2010) $17 \%$ of the European citizens are considered at-risk of poverty. According to Bijl et al. (2011) social inequality is still a difficult problem in society. Especially quality of life between low and high skilled people differ a lot (Bijl et al., 2011). Consequently the European Commission (2010) defined the Europe 2020 Strategy for among others lifting up 20 million people out of social exclusion and poverty. More concrete social inclusion is a multidimensional process of among others behavioural change depending on a persons' interaction with different situations and with different environmental conditions (Endler and Magnusson, 1976; Krueger et al., 2008; Nye and Hargreaves, 2009).

Concerning people at-risk of social exclusion we can discern different targetgroups (De la Fuente Anuncibay, 2007). As a result of different socio-demographic factors or lifecircumstances, like unemployment, lone parenthood, low educational qualifications, bad health in combination with ageing and non EU-citizenship different subgroups of people atrisk of poverty can be discerned (Tsakloglou and Papadopoulos, 2002). First of all still 22\% of the population of the industrialised countries is illiterate (UNICEF, 2008) and based on recent research findings of PIAAC (Programme for the International Assessment of Adult Competencies) we can conclude that $25 \%$ of today's fifteen-year-olds will be inadequately skilled when they are 25 years old (EARLALL, 2011). Additionally EARALL (2011) concludes that the number of low skilled workers and people excluded from lifelong learning is still increasing and that around 50 million workers do not have a certificate of upper secondary education. Secondly Dahlstedt and Bevelander (2010) note that migrants experience differences in life based on their cultural backgrounds, linguistic aspects and the distance between their country of origin and the new country. This subgroup can be considered as people, who risk social exclusion. Furthermore a part of elderly, who risk health problems, a rate of poverty or socioeconomic inequality can be considered at-risk of social exclusion (Dannefer, 2003). On the other hand support for single and young parents is needed to prevent social exclusion and exclusion from the labour market (Bynner and Londra, 2004). Finally exclusion from the labour market is still increasing according to the figures of Eurostat (2012), which presents a current unemployment rate of 10.9\% (Eurostat, 2012). The aforementioned characteristics of people at-risk of social exclusion and or better said "vulnerable adults" indicate the urgency of investment in efforts to increase social inclusion. Therefore "transition" is needed and particularly a "transition" from "vulnerable adults" into adults who are able to cope with nowadays society and its labour market. Kumpalainen (2010a) state that education systems can play an important role in supporting individual growth in citizenship among others increase of social cohesion (Kumpalainen, 2010a). Besides this LLinE refers to the importance of the pivotal role of education in increasing 
quality of life (Kumpalainen, 2010b). Accordingly the OECD (Christian, 1974) and Nilsson (2010) both indicate that lifelong learning programs or programs of adult education can be a lever in order to increase social inclusion.

More concrete a "transition" in life in order to reach social inclusion or qualification for the labour market among vulnerable adults can be reached by using adult education or programs of lifelong learning. Basic adult education can enhance transition to a better working life or better life in society especially for the aforementioned subgroup of vulnerable adults. According to the UNESCO Institute for Lifelong Learning (2009) the CONFINTEA VI Conference points out the importance of the quality of adult education in order to obtain aforementioned goals. To ensure quality and constructive outcome of adult education insights in its most important elements is necessary. To date hardly any evidence is available concerning outcome of adult education in terms of increase of social inclusion. In this article we present the most striking results of a series of studies concerning the outcome of lifelong learning programs among vulnerable adults in terms of increase of social inclusion and the significant contribution of the key elements of the learning environment. It aims to present a comprehensive overview of the results on increase of social inclusion besides the influentials of the learning environment and the trainee characteristics. The results of each study in the series have been already discussed in former articles ${ }^{2}$.

\section{Transition effects in terms of social inclusion}

Social inclusion should be defined as a multidimensional process. More concrete it can be described as a process, in which citizens try to cope with and control resources and services, have and connect to social relationships, feel included in the (local) area and take part in its activities (Van Houten, 2008; Ogg, 2005; Levitas et al., 2007; The World Bank, 2007). More concretely social inclusion can be described in terms of two dimensions. On the one hand activation and internalisation and participation and connection on the other hand (Fortuin

2 The aforementioned articles are:

- De Greef, M., Verté, D. \& Segers, M. (2011). The Impact of Education on Social Inclusion Among Vulnerable Adults: An Approach for Future Research. In Despotović, M \& Popović, K., Andragogical Studies: Journal for the Study of Adult Education and Learning. Belgrade: University of Belgrade, Faculty of Philosophy.

- De Greef, M., Segers, M. \& Verté, D. (2010). Development of the SIT, an instrument to evaluate the transfer effects of adult education programs for social inclusion. Studies in Educational Evaluation (36), 42 - 61.

- De Greef, M., Verté, D. \& Segers, M. (2012). Evaluation of the outcome of lifelong learning programmes for social inclusion: a phenomenographic research. International Journal of Lifelong Education. DOI: 10.1080/02601370.2012.663808.

- De Greef, M., Segers, M. \& Verté, D. (2012). Understanding the effects of training programs for vulnerable adults on social inclusion as part of continuing education. Studies in Continuing Education. DOI: 10.1080/0158037X.2012.664126.

- De Greef, M., Verté, D. \& Segers, M. (2012). Differential effects of adult education on adult learners' increase in social inclusion. Submitted. 
and Keune, 1997; Guildford, 2000; Mastergeorge, 2001; Verté et al., 2007). Firstly activation implies the ability of functioning in daily society as an independent individual to attain the basic needs of daily life (Movisie, 2010). More concrete it means that one for example can organise his or her own finances and can use media like TV, radio and internet (Fortuin and Keune, 1997). Besides managing basic needs in daily life one likes to be accepted in society in order to obtain an appropriate place in daily life (Guildford, 2000). According to Mastergeorge (2001) this is a process of internalisation, in which one can direct his or her own life in a happy and responsible way and is satisfied with oneself. Except for being assertive or feeling safe in and around the house, internalisation can refer to having courage in making own choices. As a result these two processes imply a large variety of variables, to be mentioned: national language skills, digital language skills, international language skills, assertiveness, labour- and upbringing skills, voluntary work- and neighbourhood skills, contact skills and financial skills.

Besides these two processes, which refer to the increase of social inclusion as an individual process, social inclusion can also be explained as a relational process in terms of the relation between the individual and his or her surroundings. More concrete we firstly can describe social inclusion as taking part in activities of the society or better said participation (Guildford, 2000) referring to doing things which one did not undertake before. Specifically it refers to visiting activities in the community, going out in the evening or taking part in official organisations (Verté et al., 2007). Secondly increasing interaction with one's surroundings means the development of new social interactions or to meet other people (Verté et al., 2007). In other words social inclusion can be a process of connection (Huisman et al., 2003; Colley, 1975). More concretely participation and connection also imply a large variety of variables, namely: attempting in associations and neighbourhood, being active in nature and sports, involving into arts and culture, getting a membership, meeting and attempting, meeting intimate contacts and preventing loneliness.

\section{The role of adult education for increasing participants' social inclusion}

Programs of adult education or lifelong learning are effective if participants experience a change in their daily life by using the insights, new skills and new attitudes they have learned in the program. This is often referred to as the transfer of training effect. This concept has been widely studied in the field of Human Resource Development (HRD) in order to get insight in the outcome of adult education (e.g. Holton, Chen and Naquin, 2003; Cheng and Hampson, 2008). Mostly these studies refer to the positive relationship between outcome of adult education and the possibility of transfer (Baldwin and Ford, 1988; Nijhuis, Segers and Gijselaers, 2005; Cheng and Hampson, 2008; Holton, Chen and Naquin, 2003; Thijssen, 2001; Nijman, 2004). According to adult education (or programs of lifelong learning) transfer refers to the implementation of learned attitude, skills and knowledge in 
daily life. In terms of training effects, HRD-studies mainly describe the outcome after joining training in terms of organisational payoffs, professional development of the participants and increase of job performance (for recent review studies, see e.g. Cheng and Hampson, 2008; Holton, Chen and Naquin, 2003). In our study, in terms of increase in social inclusion contributing to transfer of training effects, three groups of variables are discerned: (1) trainee characteristics, (2) transfer design features and (3) the participants' lifecircumstances.

\subsection{Trainee characteristics}

Social inclusion can be influenced by many variables related to the background of people atrisk. The pivotal study on social inclusion of Verté et al. (2007), which focusses on elderly, indicates that several background characteristics can enhance or block the increase of social inclusion. Regarding to Verté et al. (2007) these background characteristics are level of schooling, age, number of children, gender, racial background, marital status, motivation, (un)employment and prior diplomas and courses. More concrete his research gives more insights that needs of elderly are influenced by these socio-demographic characteristics. Secondly self-directedness in learning can be seen as an important factor relating trainee characteristics during learning (McGivney, 1992; Raemdonck, 2006). Besides Knowles (1975) Mezirow (1997) underlines the importance of self-directed learning among learners in order to influence the outcome of a learning process. More concrete Raemdonck (2006) defines self-directed learning as a process in which a learner can influence his or her own learning in order to handle his or her own situation. Moreover her study shows that the learning process of low skilled employees will be influenced by the rate of self-directness among low qualified learners. More concretely she developed two scales concerning the level of self-directness in learning and career processes on the one hand and the influence of contextual and individual conditions on self-directness on the other. According to Raemdonck (2006) both individual and contextual factors influence the self-directness during learning especially among low qualified learners. Thus the rate of self-directedness of a learner can be defined as an important background variable influencing the outcome of learning.

\subsection{The transfer design: Transfer climate, learning contents and-activities and teacher support}

Programs of lifelong learning, in which adults participate, influence their learning processes and its effects in different ways. According to Nijman (2004) the basic elements of the transfer design, comparable with the learning environment of programs of lifelong learning, are the transfer climate (including transfer possibilities and direct surroundings) next to supervisory support. 
Firstly transfer climate can be explained as the different factors in the environment of the learner, which facilitate or inhibit the use of trained skills (Burke and Baldwin 1999). This transfer climate has been evidenced as influencing the transfer of training effects. In our study the transfer climate consists of two variables, to be mentioned: "direct surroundings" and "transfer possibilities". Although the research of Nijman (2004) is conducted during a working environment our study addresses the daily life-circumstances as direct surroundings. The direct surroundings of a learner can block or stimulate transfer, but besides that the learner also needs to have the possibilities in realising transfer.

Secondly instructional approaches used by the teacher have an impact on what students learn. Many authors have argued upon the relevance of instructional approaches grounded with constructivist learning theories. More precisely Tenenbaum et al. (2001) refers to the following instructional activities: (1) arguments, discussions and debates among learners, (2) conceptual conflicts and dilemmas, (3) sharing ideas with others, (4) the use of materials and measures targeted toward solutions, (5) enhancing learners' reflections and concept investigation, (6) meeting the learners' learning needs and (7) making meaning by addressing real life examples during the instructional unit.

Thirdly in adult education the teacher plays an important role (Pratt, 1998). According to Pratt (1998) adults need to have a supportive coach, who supports them, stimulates them in using the learned competencies and help them in coping with possible resistance in daily life. During learning on the job a supervisor plays an important role. In programs of adult education different key figures play a role including the teacher. The role of the teacher is diverse and can be a trainer (Simons and Bolhuis, 2004), a consultant (Van Lakerveld et al., 2000), a supervisor (Holton, Chen and Naquin, 2003), or a guide (Van der Vlerk, 2005) in order to increase social inclusion.

\subsection{The participants' environment based on the life-circumstances}

Regarding studies on transfer of training the work environment of the trainees can have a significant contribution in improving the transfer effects of training. On the contrary in our study we address adult education or lifelong learning programs aiming increase of social inclusion. Therefore instead of the work environment the life-circumstances can be seen as the environment of the learners. Accordingly Liu (1974) and Andrews and Withey (1974) underline the importance of the life environment based on the life-circumstances of the learners. More concrete these life-circumstances refer to the learners' circumstances in which they experience life, for example their family life (Andrews and Withey, 1974). Furthermore the life environment of the learners also includes how they deal with work, the raising of children and care. This can be explained as how learners cope with challenges as functioning in a paid job, taking care for a relative or a friend and raising children (Andrews and Withey, 1974). Regarding to Andrews and Withey (1974) these kind of life-circumstances can enhance or block the increase of social inclusion among vulnerable adults. Additionally 
McGivney (1992) describes barriers in daily life-circumstances like feeling too old and mobility problems, which possibly block transfer.

\section{Research questions according the outcome of lifelong learning programs aiming social inclusion}

Due to the fact that hardly any evidence concerning outcome of adult education programs is available, five research questions should be answered. These research questions aim to gain insight in outcome and influentials of adult education programs enhancing increase of social inclusion among vulnerable adults, to be mentioned:

1. How do adults understand the impact of participating in adult education programs on their feelings of social inclusion?

2. What are the educationally critical aspects that differentiate between qualitatively varying ways of experiencing learning adult education?

3. What is the specific outcome of adult education programs in terms of social inclusion of vulnerable adults?

4. What are the differences between subgroups of participants with respect to increase in social inclusion (in terms of activation, internalisation, participation and connection) after joining programs of adult education?

5. What is the relationship between learning environment (seen as combination of lifecircumstances and transfer design) and increase of social inclusion among vulnerable adults?

\section{Results}

\subsection{Research questions 1 and 2}

The findings of the phenomenographic study indicate that learners experience an increase on four conceptions of social inclusion mentioned before as activation, internalisation, participation and connection (see table 1). 
Table 1: Conceptions of social inclusion, described in terms of themes of the learning environment

\begin{tabular}{|c|c|c|c|c|}
\hline \multirow[t]{4}{*}{ Themes } & \multicolumn{4}{|l|}{ Conceptions } \\
\hline & 1 & 2 & 3 & 4 \\
\hline & Mastery & Identity & Social Mobility & Relationships \\
\hline & (Activation) & (Internalisation) & (Participation) & (Connection) \\
\hline \multirow[t]{2}{*}{ Life-circumstances } & Managing daily life & Awareness & One's own initiative & One's own initiative \\
\hline & 25 Adult Learners & 24 Adult Learners & 11 Adult Learners & 16 Adult Learners \\
\hline \multirow[t]{2}{*}{ Teacher support } & Encourage to learn & Encourage to learn & Increase transfer & Increase transfer \\
\hline & 30 Adult Learners & 29 Adult Learners & 12 Adult Learners & 18 Adult Learners \\
\hline \multirow{3}{*}{$\begin{array}{l}\text { Learning contents } \\
\text { and-activities }\end{array}$} & Constructivistic & Constructivistic & Constructivistic & Constructivistic \\
\hline & perspective & perspective & perspective & perspective \\
\hline & 23 Adult Learners & 23 Adult Learners & 8 Adult Learners & 13 Adult Learners \\
\hline \multirow[t]{2}{*}{ Self-directedness } & Intrinsic motivation & Intrinsic motivation & Extrinsic motivation & Extrinsic motivation \\
\hline & 11 Adult Learners & 11 Adult Learners & 4 Adult Learners & 4 Adult Learners \\
\hline
\end{tabular}

Concretely, the results indicate that the increase of mastery (referring to activation) is a reachable goal for most interviewees in our study next to the increase of the feeling of having a stronger identity (referring to internalisation). For example like this learner, who explained that she bought something by herself: "I did this by myself. I surfed to www.marktplaats.nl en sought for a dishwasher. I saw an advertisement, made a phone call (by myself) and bought a dishwasher for 75 Euro". Or another learner, who felt more secure after learning: "Before I came here, I felt uncertain about myself. I didn't dare to talk and therefore I felt uncertain. (...) Now I'm going to school and I learn with other people, as I don't want to be the same pathetic person. But it helped very well, very well". On the contrary less learners experience an increase of social mobility (referring to participation) and an increase of or improvement in relationships (referring to connection), illustrated by this learner: "Yes, you meet more and more people. I came here at the same time with J. and that was the beginning of a friendship. From the very first day. If he's not here I call him asking what's the matter. It's just a kind of a friendship". In other words the results indicate that the learners more often perceive an increase of social inclusion on the individual level than on the collective components of social inclusion.

Furthermore the results indicate that especially teacher support is an important influence on the increase of social inclusion. More concretely the teacher encourages the learners to join learning or apply the learned competencies by stimulating transfer (see table 1). Likewise a learners says: "She just explained it to me and she appreciated me. I would sometimes say: "Fool, I already explained that". She didn't and that's why I appreciate that woman so much". On the contrary less learners indicate the influence of learning contents and -activities (based on a constructive perspective) in order to increase social inclusion as important as well as the influence of the life-circumstances (which supports them in managing daily life, raising awareness of the progression and need of learning and doing 
things on their own initiative), illustrated by a learner who says: "My parents and girlfriend noticed a lot of progression. (...) They told me that they used to help me, but that it is not necessary anymore". Finally the self-directedness of the learner him- or herself is only important for few of the learners in order to increase social inclusion. A learner underlines this by saying: "But look, if you want, you will succeed. That is really true. If you intend to go for it and you go for it one hundred percent then it will succeed. (...) You have to give yourself completely". According to table 1 this self-directedness of learning and the willingness to direct the own learning process is guided on the one hand by an intrinsic motivation (for example ones belief that learning can increase ones self-esteem) and on the other hand by an extrinsic motivation (for example one believe that learning is needed to cope with problems in the daily society).

\subsection{Research questions 3 and 4}

Next step of this study is to determine the rate of increase of social inclusion among learners, who joined adult education programs or programs of lifelong learning. Therefore the SIT-instrument (Social Inclusion after Transfer) has been used (De Greef, Segers and Verté, 2010). In order to determine the specific scales of the SIT-instrument a Principal Component Analysis with a Direct Oblimin Rotation by using SPSS 15.0 was conducted besides a Confirmatory Analysis by using EQS 6.1. Eventually the instrument consists of the scales: self-directed learning, training-design, life-circumstances, activation and internalisation and participation and connection . Furthermore all the items of the factors (confirming the hypothetical factors) provide a good fit to the data with $\chi 2$ of 408.40 or more by $\mathrm{N}=787$, CFI between $0.884-0.937$, RMSEA varying $0.065-0.079$ and St RMR between $0.039-0.069$.

According to table 2 a significant share of the learners experience an increase of social inclusion on the defined variables, varying form $21.8 \%$ ("getting a membership") till $54.7 \%$ ("digital language skills"). More concretely the 5 variables "digital language skills", "international language skills", "preventing loneliness", "attempting in associations and neighbourhood" and "assertiveness" report an increase of social inclusion among $40 \%$ or more of the learners. Besides this the increase of social inclusion on "activation and internalisation" seems to be with $46.3 \%$ of the learners higher than the $41 \%$ of the learners, who experience an increase on "participation and connection" (see table 2). These results are in line with the findings of research question 1 , showing that participants show more increase in activation and internalisation than in participation and connection. 
Table 2: Means and standard deviation of change in social inclusion variables for increase of social inclusion

\begin{tabular}{|c|c|c|c|c|c|c|c|}
\hline $\begin{array}{l}\text { Dependent variables of social } \\
\text { inclusion } \downarrow\end{array}$ & $\begin{array}{l}\text { Mean } \\
\text { To }\end{array}$ & SD TO & $\begin{array}{l}\text { Mean } \\
\text { T1 }\end{array}$ & SD T1 & $\begin{array}{l}\text { Mean of } \\
\text { change }\end{array}$ & $\begin{array}{l}\text { SD of } \\
\text { change }\end{array}$ & $\begin{array}{l}\text { \% of } \\
\text { population } \\
\text { experiencing } \\
\text { increase }\end{array}$ \\
\hline Activation and internalisation & 6.83 & 1.37 & 7.60 & 1.24 & 0.77 & 0.88 & 46.3 \\
\hline National language skills & 7.15 & 1.42 & 8.22 & 1.23 & 1.08 & 1.02 & 34.5 \\
\hline Digital language skills & 5.03 & 2.23 & 7.55 & 1.98 & 2.52 & 2.01 & 54.7 \\
\hline International language skills & 4.70 & 2.58 & 6.73 & 2.35 & 2.03 & 1.53 & 45.2 \\
\hline Assertiveness & 6.70 & 1.67 & 7.99 & 1.38 & 1.29 & 1.29 & 40.9 \\
\hline Labour- and upbringing skills & 5.99 & 2.14 & 7.78 & 1.86 & 1.78 & 1.35 & 29.7 \\
\hline $\begin{array}{l}\text { Voluntary work- and } \\
\text { neighbourhood skills }\end{array}$ & 3.81 & 2.22 & 6.32 & 2.05 & 2.50 & 1.65 & 35.4 \\
\hline Contact skills & 7.12 & 1.73 & 8.30 & 1.34 & 1.18 & 1.18 & 35.3 \\
\hline Financial skills & 6.00 & 2.36 & 7.98 & 2.01 & 1.98 & 1.35 & 23.9 \\
\hline Participation and Connection & 4.03 & 1.00 & 4.30 & 1.14 & 0.64 & 0.61 & 41.0 \\
\hline $\begin{array}{l}\text { Attempting in associations and } \\
\text { neighbourhood }\end{array}$ & 3.06 & 2.06 & 4.77 & 2.34 & 1.71 & 1.25 & 41.4 \\
\hline Being active in nature and sports & 5.41 & 1.79 & 6.94 & 1.58 & 1.53 & 1.32 & 30.9 \\
\hline Involving into arts and culture & 3.98 & 2.06 & 6.60 & 1.82 & 2.63 & 1.68 & 29.3 \\
\hline Getting a membership & 1.23 & 0.26 & 1.60 & 0.30 & 0.36 & 0.22 & 21.8 \\
\hline Meeting and attempting & 5.91 & 1.90 & 7.66 & 1.60 & 1.75 & 1.58 & 32.4 \\
\hline Meeting intimate contacts & 7.24 & 1.36 & 8.27 & 1.16 & 1.02 & 1.06 & 36.4 \\
\hline Preventing loneliness & 2.25 & 0.52 & 2.62 & 0.39 & 0.37 & 0.36 & 44.3 \\
\hline
\end{tabular}

Furthermore it became clear that groups with different ethnic background discerned, show different patterns towards increase of social inclusion. More concrete foreign learners show more increase on the variables "national language skills" $(U(417)=9422.5 ; p=0.028)$, "meeting and attempting" $(\mathrm{U}(407)=8695 ; \mathrm{p}=0.021)$ and "meeting intimate contacts" ( $\mathrm{U}$ $(415)=9222.5 ; p=0.018)$ than autochthone learners. Besides this the Dutch learners show more increase on "involving into arts and culture" $(U(370)=8065 ; p=0.039)$ than foreign learners.

Finally our study shows that learners with a different marital status also show different patterns towards increase of social inclusion. More concrete people who are living together (and are not married) experience more increase on "national language skills" $(H(3,416)=$ $19.568, p=0.000)$, "digital language skills" $(H(3,405)=10.754, p=0.013)$, "assertiveness" $(H(3,404)=18.266, p=0.000)$, "labour- and upbringing skills" $(H(3,321)=7.925, p=$ $0.048)$, "contact skills" $(\mathrm{H}(3,393)=18.328, \mathrm{p}=0.000)$, "meeting and attempting" $(\mathrm{H}$ $(3,406)=9.451, p=0.024)$, "meeting intimate contacts" $(H(3,414)=9.978, p=0.019)$ and on the scale "activation and internalisation" $(H(3,430)=12.665, p=0.005)$ than people who are married, unmarried or widowed. 
Besides this the results show that men experienced more increase on assertiveness than women and that older learners show a higher increase on digital skills than younger learners. Furthermore the findings show that people with few children show a higher increase of assertiveness and are less isolated and that people with limited education (for example (special) primary school) show a higher increase on certain skills, such as international language skills and meeting intimate contacts compared to learners with higher levels of education. Finally the results do not show any different patterns for subgroups concerning background variables of (un)employment, motivational orientation and self-directedness in learning.

\subsection{Research question 5}

Finally the results of the logistical regression give insights in the influence of the elements of the learning environment on the increase of the different variables of social inclusion. According to table $3 \mathrm{~A}$ it becomes clear that on the scale of "activation and internalisation" "transfer possibilities" seems to be a significant predictor for most variables, namely: "digital skills", "assertiveness", "labour- and upbringing skills" and "voluntary work and neighbourhood skills". More concrete if one has enough possibilities to apply the learned knowledge, skills or attitude one's increase in digital skills, assertiveness, labour- and upbringing skills, voluntary work and neighbourhood skills will be positively influenced. Besides this 4 elements of the learning environment seem to be a significant predictor for just one or two variables of the scale of "activation and internalisation", to mention: "barriers" on "international language skills", "care" on "attempting in associations and neighbourhood", "upbringing and work" on "labour- and upbringing skills" and "voluntary work and neighbourhood skills" and "learning contents and -activities" on "contact skills" (see table 3A). More concrete if one experience barriers the increase of one's international language skills can be blocked. Besides this if one has to take care for a relative or a friend one's involvement in associations and neighbourhood can be influenced. Furthermore if one has a job or has to raise children his or her labour- and upbringing skills will be influenced next to one's voluntary work- and neighbourhood skills. Finally one's contact skills will be influenced if the learning contents and -activities are based on a constructive perspective during the learning process.

Furthermore the variable "transfer possibilities" seems to be the only variable influencing the scale "participation and connection" and more concretely the variables "attempting in associations and neighbourhood", "involving into arts and culture" and "getting a membership" (see table 3B). This means that the possibilities to apply learned knowledge, skills or attitude influence one's involvement in associations and the neighbourhood, besides one's participation in activities of arts and culture and if one becomes a member of an association. 
According to the findings of the phenomenographic study these results are partly in line with the results of the first research question. Regarding the findings of research question 1 the life-circumstances and learning contents and -activities are indeed perceived as important influentials for the increase of social inclusion among the participants. On the contrary the findings of research question 1 seem to confirm the importance of teacher support, which is not the case on the results of the logistical regression. 


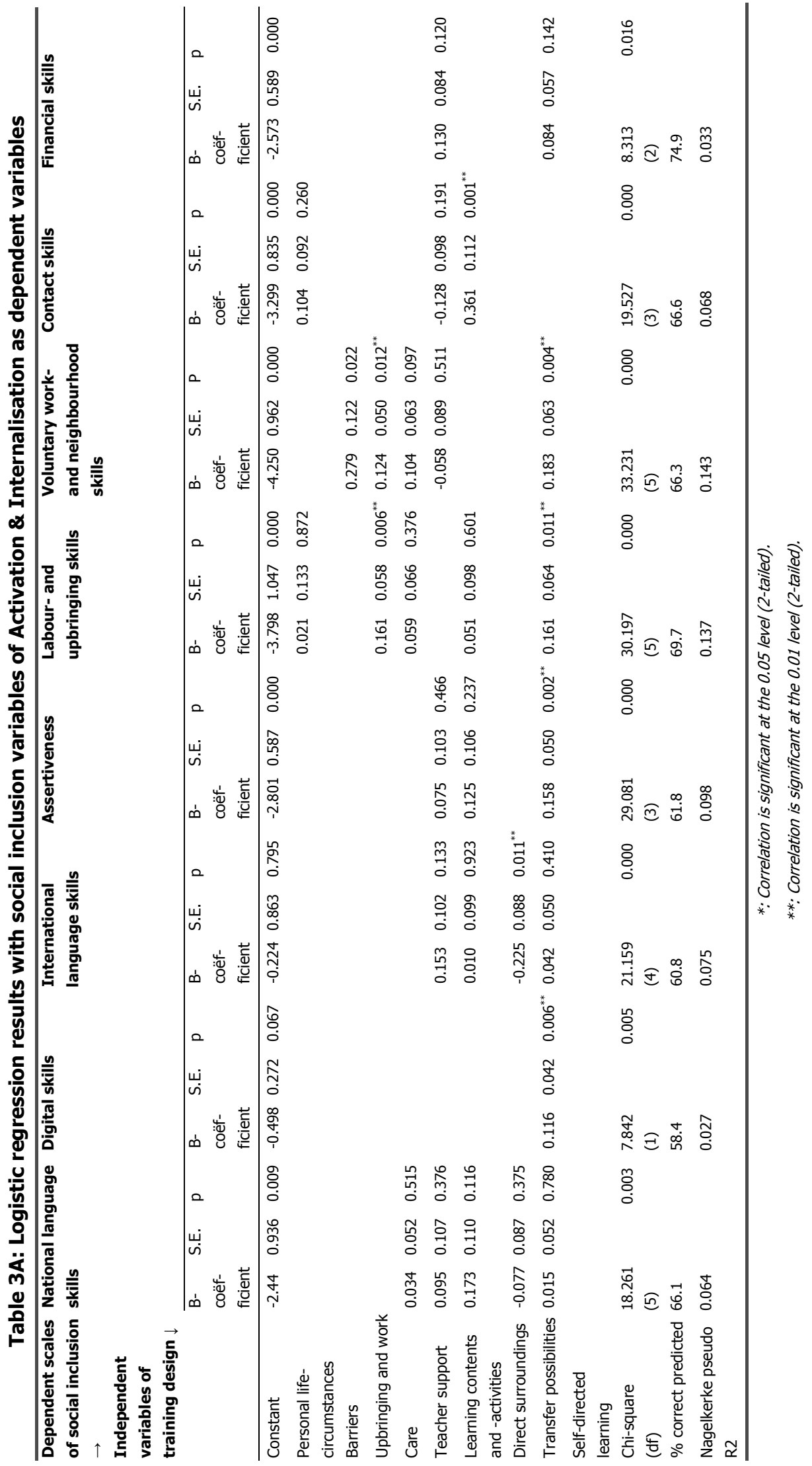




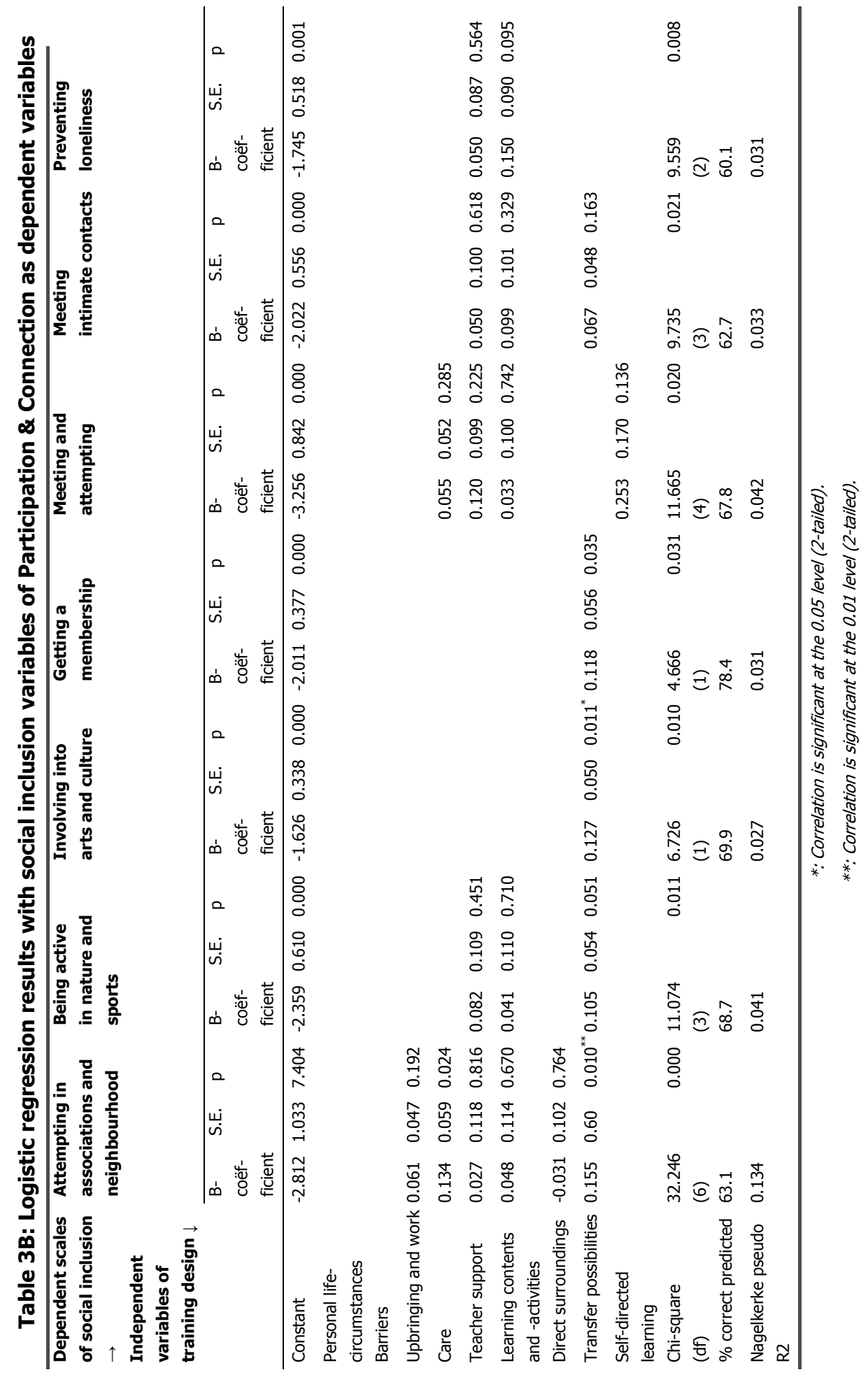




\section{Implications for practice: "Transition to social inclusion by lifelong learning"}

Regarding our study it is obvious that some learners undergo a "transition" to better social inclusion after joining programs of lifelong learning. Especially on four conceptions of social inclusion, namely activation, internalisation, participation and connection. More concrete on some variables of social inclusion (belonging to these four processes of social inclusion) our results show an increase for $40 \%$ of the learners or more. Besides an increase of social inclusion among $46.3 \%$ of the learners on the scale "activation and internalisation" we can report an increase for $41 \%$ of the learners on the scale "participation and connection". But maybe even more important are the insights in its most important elements to ensure quality of adult education, which seems one of the most important needs concluded at the CONFINTEA VI Conference according to the UNESCO Institute for Lifelong Learning (2009). More concretely the variable "transfer possibilities" seems to influence most variables of social inclusion. In other words the possibilities for transfer of learned knowledge, skills and attitude (facilitated by the learning environment) seems to influence the rate of increase of social inclusion. Thus if managers and teachers in adult education aim to optimise their learning programs in order to increase the learning success focus on enhancing transfer possibilities during learning is needed. This means that lifelong learning programs of adult education centres should include time and support in order to gain possibilities to apply used knowledge, skills and a new attitude in daily life. For some lifelong learning programs this means a restructuring of goals, instructional approaches and design of learning contents and -activities. Several practical ideas can be suggested according to the results of the several studies.

Firstly one has to develop learning programs, which are based on a constructive perspective due to the fact that the learning contents and -activities (based on a constructive perspective) seems to influence the increase of some variables of social inclusion. Regarding the key elements of the constructive perspective using daily life examples is a strong tool to optimise the learning process. Especially for our targetgroup vulnerable adults, who possibly can experience barriers during learning, it seems to be necessary to provide insights in the possibilities of using their learned knowledge and skills in daily life. With providing daily life examples during the learning process vulnerable adults can understand the possible surplus value of learning new knowledge or skills.

Secondly based on the findings of the phenomenographic study the teacher has to support the learners in encouraging them to learn and apply their learned knowledge, skills and attitude. More concretely the teacher becomes a facilitator in order to develop a safe learning environment for vulnerable adults, in which they would like to reflect on their current knowledge and skills in order to improve their situation in daily life. Besides this the teacher gives examples and explains possibilities for transfer. More concretely he or she 
stimulates the learner (for example with exercises) in using the new competencies in daily life.

Thirdly according to the results of the logistic regression the lifelong learning programs of adult education centres should focus more on the enhancement of transfer possibilities. More concrete teaching in the classroom will not be sufficient for reaching learning success, but coaching during learning in daily life is needed.

Finally the results of the non-parametric analysis also show that for example foreign learners and learners who are not married, but live together will be successful in other elements of social inclusion than autochthone learners or learners who are married. Therefore lifelong learning programs need to be tailor made .

\section{Suggestions for further research}

First of all our findings are based on the Dutch context. In order to cross validate our results in other cultural settings it would be a possibility to conduct a comparable research in several countries. This in order to validate the SIT-instrument and to explore differential effects for different cultural settings. A first step is realised by conducting the EDAM-research in eight European countries (Lupi et al., 2011).

Secondly more research is needed in order to cross validate our predictive model and to optimise its predictive value in order to explore the rate of and possible influences on learning success after lifelong learning for vulnerable adults. According to Cascallar and Musso (2008) for example "Neural Network Analysis" can be considered to be a good statistical model in predicting complex phenomena. This research method can be used to define a large group of variables predicting the outcome in terms of social inclusion. Finally our research is based on self-reports of the participants at the beginning, during and afterwards their learning process. This seems to be a good possibility in describing the perceived increase of social inclusion. Still it can be useful to use other proxy data, which overcome possible biases as a result of the self-reporting of the participants.

Our current study is still a first step in describing the outcome and effects of adult education programs (or better said lifelong learning programs) aiming increase of social inclusion among vulnerable adults. Future research and the use of insights of the results of our study can stimulate professionals and researchers of lifelong learning to improve the learning environment of lifelong learning in adult education centres in order to ensure a "transition" to social inclusion for those who are at-risk of social exclusion. 


\section{References}

Andrews, F. M. \& Withey, S. B. (1974). Developing measures of perceived life quality: Results from several national surveys. Social Indicators Research, 1974 (1), 26.

Baldwin, T. T. \& Ford, K. J. (1988). Transfer of training: A review and directions for future research. Personnel Psychology, 1988 (41), 43.

Bijl, R., Boelhouwer, J., Cloin, M. \& Pommer, E. (2011). De sociale staat van Nederland 2011. Den Haag: Sociaal Cultureel Planbureau.

Burke, L.A., \& Baldwin, T.T. (1999). Workforce training transfer: A study of the effect of relapse prevention training and transfer climate. Human Resource Management, 38 (3), 227 - 242.

Bynner, J. \& Londra, M. (2004). The impact of government policy on social exclusion among young people. London: The Office of the Deputy Prime Minister.

Cascallar, E. C. \& Musso, M. (2008). Classificatory Stream Analysis in the Prediction of Expected Reading Readiness: Understanding Student Performance. International Journal of PSychology, XXIX International Congress of Psychology ICP 2008, 43, (3/4): 231.

Cheng, E. W. L. \& Hampson, I. (2008). Transfer of training: A review and new insights. International Journal of Management Reviews 10 (4), 15.

Christian, D. E. (1974). International Social Indicators: The OECD Experience. Social Indicators Research 1 (2), 169.

Colley, D. G. (1975). A social change index - an objective means to discern and measure the relative current social condition of cities, towns, and their sub-communities. Social Indicators Research, 1975 (1), 26.

Dahlstedt, I. \& Bevelander, P. (2010). General versus vocational education and employment integration of immigrants in Sweden. Journal of Immigrant and Refugee Studies, 8 (2), 158 - 193.

Dannefer, D. (2003). Cumulative Advantage / Disadvantage and the Life Course: Cross-Fertilizing Age and Social Science Theory. Journal of Gerontology: Social Sciences 58B (6), 327 - 337.

De Greef, M., Segers, M. \& Verté, D. (2010). Development of the SIT, an instrument to evaluate the transfer effects of adult education programs for social inclusion. Studies in Educational Evaluation (36), $42-61$.

De Greef, M., Verté, D. \& Segers, M. (2012). Evaluation of the outcome of lifelong learning programmes for social inclusion: a phenomenographic research. International Journal of Lifelong Education. Accepted and in press.

De la Fuente Anuncibay, R. (2007). Social, personal and educational constraints on access to employment among groups at risk of social exclusion: contributions from an employment observatory. Journal of Vocational Education and Training, 59 (4), 435 - 449.

EARLALL - European Association of Regional and Local Authorities for Lifelong Learning. (2011). Policypaper: Decreasing the number of low-skilled people. Bruxelles: EARLALL.

Endler, N., S. \& Magnusson, D. (1976). Toward an interactional psychology of personality. Psychological Bulletin, 83, 956 - 974.

European Commission. (2010). Communication from the commission to the European Parliament, the Council, the European Economic and Social Committee and the Committee of the Regions: The 


\section{European Platform against Poverty and Social Exclusion: A European framework for social and}

territorial cohesion. Brussels: European Commission.

Eurostat (2010). Combating poverty and social exclusion. Luxembourg: European Union.

Eurostat (2012). Euro area unemployment rate at 10.3\%. Luxembourg: Eurostat.

Fortuin, K. and Keune, C. (1997). Anders praten over jeugd: Naar een begrippenkader voor preventief jeugdbeleid. Utrecht: Verwey-Jonker Instituut.

Guildford, J. (2000). Making the case for social and economic inclusion. Canada Atlantic Region: Population and Public Health Branch.

Holton, E. F., Chen H. \& Naquin, S. S. (2003). An examination of learning transfer system characteristics across organizational settings. Human Resource Development Quarterly, vol. 14 (4), 24.

Huisman, J., Pijls, T., Van Hoeij, J., Van Voorst van Beest, K., Boonaerts, Y. \& Lens, M. (2003). Portfolio sociale competenties: Primair onderwijs, vmbo, mbo. 's-Hertogenbosch: CINOP.

Knowles, M. S. (1975). Self-directed learning: A guide for learners and teachers. New York: Association Press.

Krueger, R. F., South, S., Johnson, W. Iacono, W. (2008). The heritability of personality is not always 50\%: Gene-environment interactions and correlations between personality and parenting. Journal of Personality, 76, 1485 - 1522.

Kumpulainen, K. (2010a). Social cohesion as intercultural dialogue. Lifelong Learning in Europe, vol. 15 (1).

Kumpulainen, K. (2010b). Learning promotes wellbeing - Wellbeing promotes learning. Lifelong Learning in Europe, vol. 15 (2).

Levitas, R., Pantazis, C., Fahmy, E., Gordon, D., Lloyd, E. \& Patsios, D. (2007). The Multidimensional analysis of social exclusion. London: Department for Communities and Local Government.

Liu, B. (1974). Quality of life indicators: a preliminary investigation. Social Indicators Research, 1974 (1), 22, 187 - 208.

Lupi, C. De Greef, M., Segers, M. \& Verté, D. (2011). Does adult education make a difference? Maastricht: EDAM.

Marton, F. \& Booth, S. (1997) Learning and awareness. Mahwah, N. J.: Lawrence Erlbaum.

Marton, F., Watkins, D. \& Tang, C. (1997). Discontinuities and continuities in the experience of learning: an interview study of high-school students in Hong Kong. Learning and Instruction, vol. 7 (1), 21 - 48.

Mastergeorge, A. M. (2001). Guided Participation in sociocultural learning: Intervention and apprenticeship. Academic Search Premier, 22 (1), 14.

McGivney, V. (1992). Tracking adult learning routes: A pilot investigation into adult learners'starting points and progression to further education and training. Leicester: National Institute of Adult Continuing Education.

Mezirow, J. (1997). Transformative Learning: Theory to Practice. In: Transformative learning in action: insights from practice. New directions for adult and continuing education, 74, 5 - 12.

Movisie (2010). Activering, 2010. 20 - 3 - 2010. <http://www.movisie.nl/125241/def/home_/activering/wat_is_activering/activering/>.

Nijhuis, J. F. H., Segers, M. S. R. \& Gijselaers, W. H. (2005). Influence of redesigning a learning environment on student perceptions and learning strategies. Learning Environments Research, 2005 (8), 27. 
Nijman, D.J.J.M. (2004). Supporting Transfer of Training: Effects of the Supervisor. Enschede: Universiteit Twente.

Nilsson, A. (2010). Vocational education and training - an engine for economic growth and a vehicle for social inclusion. International Journal of Training and Development, 14, 4, 251 - 272.

Nye M. \& Hargreaves, T. (2009). Exploring the Social Dynamics of Proenvironmental Behavior Change: A Comparative Study of Intervention Processes at Home and Work. Journal of Industrial Ecology, vol. $14(1), 137$.

Ogg, J. (2005). Social exclusion and insecurity among older Europeans: the influence of welfare regimes. Ageing \& Society, 25, 69.

Pratt, D. D. (1998). Five perspectives on teaching in adult and higher education. Malabar, Florida: Krieger Publishing Company.

Raemdonck, I. (2006). Self-directedness in learning and career processes: A study in lower-qualified employees in Flanders. Gent: Universiteit van Gent.

Simons, R-J. S. \& Bolhuis, S. (2004). Constructivist learning theories and complex learning environments. In Mulder, R.H. \& Sloane, P.F.E., New approaches to vocational education in Europe. The construction of complex learning-teaching arrangements. Oxford: Symposium Books; and in Oxford Studies in Comparative Education, 13 (1), 13 - 25.

Tenenbaum, G., Naidu, S., Jegede, O. \& Austin, J. (2001). Constructivist pedagogy in conventional on campus and distance learning practice: An exploratory investigation. Learning and construction 11, 25.

The World Bank. (2007). Social Exclusion and the EU's Social Inclusion Agenda: Paper Prepared for the EU8 Social Inclusion Study. Washington: The World Bank.

Thijssen, J. (2001). Personele flexibiliteit in strategisch perspectief: De betekenis van employability voor organisatie en individu. In R. Poell \& J. Kessels, Human Resource Development, Organiseren van het leren. Alphen aan den Rijn: Samsom, 103 - 116.

Tsakloglou, P. \& Papadopoulos, F. (2002). Aggregate level and determining factors of social exclusion in twelve European countries. Journal of European Social Policy 12 (3), 211 - 225.

UNESCO Institute for Lifelong Learning - UIL. (2009) Global Report on Adult Learning and Education: Executive Summary. Hamburg: UNESCO Institute for Lifelong Learning - UIL.

UNICEF. (2008). The state of the world's children. New York: UNICEF.

Van Houten, D. (2008). Werken aan inclusie. Tijdschrift Sociale Interventie, 17 (3), 45 - 56.

Van der Vlerk, D. (2005). Inspireren tot leren: Het ontwerpen van een uitdagende leeromgeving. Bussum: Uitgeverij Coutinho.

Van Lakerveld, J., Van den Berg, J., De Brabander, C., \& Kessels, J. (2000). The corporate curriculum: a working-learning environment. In Proc. Annual Academy of Human Resource Development Conference: Expanding the Horizons of Human Resource Development. Raleigh-Durham NC.

Verté, D., De Witte, N. \& De Donder, L. (2007). Schaakmat of aan zet? Monitor voor lokaal ouderenbeleid in Vlaanderen. Brugge: Uitgeverij Van den Broele. 



\section{About the author}

\section{Biography}

Maurice de Greef is master in educational science and started his promotion (PHD) about the outcome of adult education to become professor in adult education. He managed local, regional and European projects in innovating learning environments, strategic policy-making in adult education and developing strategies for approaching learners and realising new courses in local settings. He trains teachers on these topics. Besides this he is member of the national board of non-formal adult education and responsible for the national conferences about adult education. Furthermore he is member of the board of the national organisation for civil servants of education and project manager in realising new learning environments for minority groups.

\section{List of publications}

\section{International publications}

2012

- De Greef, M., Segers, M. \& Verté, D. (2012). The Impact of lifelong learning programs on social inclusion among vulnerable adults. Lifelong Learning in Europe. Vol. XVII, Issue 1.

- De Greef, M., Segers, M. \& Verté, D. (2012). Understanding the effects of training programs for vulnerable adults on social inclusion as part of continuing education. Studies in Continuing Education. DOI: 10.1080/0158037X.2012.664126.

- De Greef, M., Verté, D. \& Segers, M. (2012). Evaluation of the outcome of lifelong learning programmes for social inclusion: a phenomenographic research. International Journal of Lifelong Education. DOI: 10.1080/02601370.2012.663808.

- De Greef, M., Verté, D. \& Segers, M. (2012). Differential effects of adult education on adult learners' increase in social inclusion. Submitted.

2011

- De Greef, M., Verté, D. \& Segers, M. (2011). The Impact of Education on Social Inclusion Among Vulnerable Adults: An Approach for Future Research. In Despotović, M \& Popović, K., Androgogical Studies: Journal for the Study of Adult Education and Learning. Belgrade: University of Belgrade, Faculty of Philosophy.

- Lupi, C. De Greef, M., Segers, M. \& Verté, D. (2011). Does adult education make a difference? Maastricht: EDAM.

- Tyrie-Socha et al. (2011). New Approaches, New Skills for Social Inclusion. London: AOC 
- De Greef, M., Segers, M. \& Verté, D. (2010). Development of the SIT, an instrument to evaluate the transfer effects of adult education programs for social inclusion. Studies in Educational Evaluation (36), 42 - 61.

2008

- De Greef, M. (2008). Active citizenship: The power of the context and facilitation (Dutch perspective). Mommaerts, S., Devlin, W., De Greef, M., Grignoli, D., Di Paolo, M. \&

Rupprechter, M. Reflections and contents of the project Easy. Berchem: EPO Drukkerij. 2007

- De Greef, M. (2007). Vraaggerichte wijkeducatie. Perspectief, 3 (3).

2006

- De Greef, M. (2006). Green and grey as a dynamic combination: Paper about intergenerational work for the project Easy.

- De Greef, M. \& Arens, M. (2006). The voice of the citizen: dream or reality: About the chances and possible troubles of civic participation. In Petersen, T.T., Building Real Inclusion and Democratic Governance through Education. Copenhagen: Copenhagen Adult Education Institute.

2008 - 2011: European articles for database INFONET

- INFONET: Use don't lose it (2011)

- Adult Education in the Netherlands (2011)

- Mentoring digital learning for the unskilled: Room for self-guidance (2011)

- Study Circle: Voluntary participation in third-age education is a global success (2011)

- Voluntary participation in third-age education (2010)

- What does adult education provide according to the participants themselves? (2010)

- Interactive target group analysis ensures success of educational programmes with immigrants (2010)

- Students are our main source of inspiration (2010)

- Adult education is preparing European citizens for knowledge economy! (2010)

- Learning by art about homeless people: The Power of Local Community Arts Project (2009)

- Successful Initial Scientific Study on the Outcome and Influence of Adult Education! (2009)

- Attract and Retain: The best way to counsel the poorly-educated towards adult education (2009)

- Senior citizens pass the force of nature to the young (2009)

- New opportunity in the Netherlands: Societal education! (2009)

- Reflection of Talent: Intergenerational work with Community Arts (2008)

- Easy: Youths put the life story of seniors on the stage (2008)

- Does education yield any results or is it just a leisure pursuit? (2008)

- The latest trend in the Netherlands: Demand-driven education in the local area (2008) 
- De Greef, M. (2012). Leren in verschillende contexten: De opbrengsten van trajecten taal- en basisvaardigheden voor laagopgeleiden. 's-Hertogenbosch: CINOP.

- De Greef, M. (2012). Naar een begrippenkader van digitaal leren voor reguliere en zorgleerlingen. Nijmegen / 's-Hertogenbosch: Van der Burgt Computereducatie / Artéduc.

2011

- De Greef, M. (2011). Laagopgeleide bepaalt leren het liefst zelf. SW-Journaal, 12 (40).

- De Greef, M. (2011). Succesvol digitaal leren voor laagopgeleiden. Alfanieuws, 14 (4).

- De Greef, M. (2011). Educatietrajecten in 's-Hertogenbosch zorgen voor betere participatie bij inwoners. Almere: IVIO Didactiek.

- De Greef, M. (2011). Participatieopleidingen van ROC Midden Nederland zorgt voor een betere plek in de samenleving. 's-Hertogenbosch: Artéduc.

- De Greef, M. (2011). Ondersteuning en certificering van digitaal leren voor laagopgeleiden. 's-Hertogenbosch: Artéduc.

- De Greef, M. (2011). Het Participatiebudget: eindelijk nieuwe kansen voor duurzame non-formele scholing voor kwetsbaren. In Eveleens, D, Michielse, H. \& Vuyk, S., Leren voor leven. Bakkeveen: Stichting voor Volkshogeschoolwerk in Nederland, 46 - 49.

- De Greef, M. (2011). Duurzame effecten Leren voor leven. Velp: Spectrum CMO Gelderland.

- De Greef, M. \& Heringa, L. (2011). Er zit muziek in. Vught: Stichting Vrienden van Vughterstede

- Graafsma, L. \& Greef, M. de. (2011). De effectiviteit van educatie. Profiel Vakblad, 20 (3).

2010

- De Greef, M. (2010). Rendement van volwasseneneducatie van ROC van Amsterdam (KAN) en ROC Aventus. Velp: Spectrum CMO Gelderland.

2009

- Greef, M. de (2009). De kick in het werk. In Bohnenn, E. et al., NT1 Handboek. Rotterdam: ETV.nl.

- De Greef, M. et al. (2009). Leren voor Leven een eigen plek in het dagelijks leven. Velp: Spectrum CMO Gelderland.

2008

- De Greef, M. (2008). Spiegel van het talent. Velp: Spectrum CMO Gelderland.

- De Greef, M. (2008). Samenwerking in educatieve ketens: Help de concurrentie of harmonie? Actueel. Velp: Spectrum CMO Gelderland.

- De Greef, M. et al. (2008). De studiekring is OK! Velp: Spectrum, Centrum Maatschappelijke Ontwikkeling Gelderland. 
- De Greef, M. et al. (2008). Leren in de wijk: Inspiratiebron voor professionals. Velp: Spectrum CMO Gelderland.

- De Greef, M \& Van de Braak, M. (2008). Samenwerking in de Brede School: Succes verzekerd? Actueel. Velp: Spectrum CMO Gelderland.

2007

- De Greef, M. et al. (2007). De kracht van Grijs op Eigen Wijs. Actueel. Velp: Spectrum CMO Gelderland.

- De Greef, M. et al. (2007). Vraaggerichte educatie in de wijk en haar 4 lessen. Actueel. Velp: Spectrum CMO Gelderland.

- De Greef, M., et al. (2007). Interactieve doelgroepanalyse verzekert succes van programma's. Actueel. Velp: Spectrum CMO Gelderland.

- De Greef, M., Bersée. T., Jongeneelen, J., Meziani, M. (2007). Gelders actieplan laaggeletterd: Leer, lees, leef! Velp: Spectrum CMO Gelderland.

- De Haan, M. \& De Greef, M. (2007). Leermogelijkheden in het kader van de Wmo. Velp: Spectrum, Centrum Maatschappelijke Ontwikkeling Gelderland.

2006

- De Greef, M. (2006). De buurt geactiveerd: en dan? Actueel. Velp: Spectrum CMO Gelderland.

- De Greef, M. (2006). "Leren in de Wijk" is hot! Actueel. Velp: Spectrum CMO Gelderland.

- De Greef, M. (2006). De ouderen top 5. Actueel. Velp: Spectrum CMO Gelderland.

- Arens, M. \& De Greef, M. (2006). De burger aan het woord: trend of werkelijkheid. Visies, 1. Arnhem: Enzovoort.

- Houtepen, J., Uyterlinde, M., Engbersen, R., Megens, B. \& De Greef, M. (2006). Leren in de wijk als inspiratiebron voor de bewoner. Velp: Spectrum, Centrum Maatschappelijke Ontwikkeling Gelderland.

2005

- De Greef, M. (2005). Volwasseneneducatie en welzijn hand in hand in Gelderland. Actueel. Velp: Spectrum CMO Gelderland.

- De Greef, M. (2005). Toekomstscenario's ouderenadvisering Gemeente Groenlo / Lichtenvoorde. Velp: Spectrum CMO Gelderland.

- Greef, M. de \& Gelders ROC Netwerk. (2005). Toekomstscenario's Volwasseneneducatie. Velp: Spectrum, Centrum Maatschappelijke Ontwikkeling Gelderland.

- Janssen, T. \& De Greef, M. (2005). Mederedacteur "Op Wereldreis in Wijchen: Een cursus om ouderen toe te leiden naar vrijwilligerswerk". Velp: Spectrum, Centrum Maatschappelijke Ontwikkeling Gelderland.

- Van Dongen, E., Klein Rouweler, E., Stein, H. \& De Greef, M. Spectrum Signalement: Ouderenadviseur als pionier in wonen - welzijn - zorg. Velp: Spectrum CMO Gelderland.

- Venhuizen, E. \& De Greef, M. (2005). Kansen voor kennis: Een onderzoek naar kennisdeling. Nijmegen: Radboud Universiteit. 
- De Greef, M. (2004). Nieuwe kansen en projecten voor de Gelderse volwasseneneducatie. Actueel. Velp: Spectrum CMO Gelderland.

- Smeenk, M. \& De Greef, M. Samen één voor ouderenbeleid in Groenlo. Velp: Spectrum CMO Gelderland.

2003

- De Greef, M. (2003). Volwasseneneducatie en welzijn in samenspel. Velp: Spectrum CMO Gelderland.

- De Greef, M. (2003). Financiering ouderenadviseur: Creativiteit en vraagtekens. Actuee/. Velp: Spectrum CMO Gelderland.

- De Greef, M. (2003). Ouderenadviseur waarborgt welbevinden toekomstige oudere. Actueel. Velp: Spectrum CMO Gelderland.

Co-author and editor in chief

- Co-author of "Denken, durven, doen: Handboek Buurtacademie".

- Co-author of "Onderwijseenheid HBO CMV De Activiteitenprogrammeur Deel 1".

- Editor in chief handleiding "Senioreneducatie op de kaart". 



\section{Samenvatting}

Een aanzienlijk deel van de huidige Europese bevolking wordt bedreigd door sociale uitsluiting. Dit blijkt bijvoorbeeld uit cijfers van Eurostat (2010), die zich met name richten op economische maten van sociale inclusie zoals armoede en tewerkstelling. Deze cijfers indiceren dat $17 \%$ van de huidige Europese bevolking op of onder de armoedegrens leeft en dat het werkloosheidscijfer sinds de geconstateerde 7\% van 2008 blijft toenemen. Bijl et al. (2011) geeft aan dat deze sociale ongelijkheid een hardnekkig probleem in onze samenleving blijft. Er is vooral een grote kloof waarneembaar tussen hoog- en laagopgeleiden, waarbij laagopgeleiden een grotere kans lopen om uitgesloten te worden van zowel maatschappelijke als arbeidsparticipatie. Dientengevolge heeft de Europese Commissie (2010) een "Europe 2020" agenda ontwikkeld met onder andere als doel toename van sociale inclusie voor 20 miljoen mensen.

Sociale inclusie is echter meer dan een economisch probleem. In dit proefschrift gaan we uit van sociale inclusie als een multidimensionaal proces van gedragsverandering, dat afhankelijk is van iemands interactie in verschillende situaties en onder verschillende omstandigheden in zijn of haar omgeving (Endler en Magnusson, 1976; Krueger et al., 2008; Nye en Hargreaves, 2009).

Sociale exclusie treft verschillende groepen (De la Fuente Anuncibay, 2007). Tsakloglou en Papadopoulos (2002) onderscheiden verschillende groepen op basis van sociodemografische factoren of levensomstandigheden, zoals werkloosheid, alleenstaand ouderschap, opleidingsniveau, zwakke gezondheid in combinatie met vergrijzing en etnische afkomst. Volgens UNICEF (2008) is bijvoorbeeld $22 \%$ van de bevolking van de geïndustrialiseerde landen laaggeletterd en de onderzoeksresultaten van PIAAC (Programme for the International Assessment of Adult Competencies) geven aan dat $25 \%$ van alle 15 -jarigen ongekwalificeerd zullen zijn in hun 25e levensjaar (EARLALL, 2011). Daarnaast constateren Dahlstedt en Bevelander (2010) dat migranten op basis van hun etnische afkomst moeilijkheden ondervinden op het gebied van taal en een afstand ervaren tussen hun thuisland en het immigratieland. Naast immigranten, riskeert ook een deel van de ouderen sociale uitsluiting, vanwege onder meer gezondheidssituatie (bijvoorbeeld beperkte mobiliteit) of lage inkomen (Dannefer, 2003). Maar ook alleenstaande of jonge ouders lopen risico uitgesloten te worden van de maatschappij en de arbeidsmarkt (Bynner en Londra, 2004) evenals de huidige 10.9\% werklozen in Europa (Eurostat, 2012).

De omvang van de problematiek van sociale exclusie vereist een antwoord op de vraag hoe kwetsbare groepen kunnen worden ondersteund, zodat ze een betere plek in de samenleving weten te vinden. Naast Nilsson (2010) geeft de OECD (Christian,1974) aan dat levenslang leren een geschikte interventie kan zijn om ervoor te zorgen dat de sociale inclusie onder deze kwetsbare volwassenen toeneemt. Volwasseneneducatie kan ervoor zorgen, dat kwetsbare volwassenen een betere plek op de arbeidsmarkt en in de samenleving krijgen. 
Volgens het UNESCO Institute for Lifelong Learning (2009) onderstrepen de uitkomsten van de CONFINTEA VI conferentie het belang van een kwalitatief goede volwasseneneducatie. Echter, tot op heden is er weinig evidentie van de opbrengsten van volwasseneneducatie in termen van sociale inclusie. Tegelijk is er weinig evidentie over welke kenmerken van de leeromgeving in programma's voor volwassenonderwijs bijdragen aan het realiseren van deze opbrengsten. Dit proefschrift geeft antwoord op de vraag wat deelnemers van volwassenonderwijs bereiken in termen van sociale inclusie na deelname aan educatie. Daarbij wordt inzichtelijk gemaakt of er verschillen in opbrengsten zijn tussen subgroepen. Tot slot wordt onderzocht welke elementen van de leeromgeving het meeste invloed hebben op de bereikte leerwinst.

\section{Transfer van educatie in termen van sociale inclusie}

Sociale inclusie kan gezien worden als een multidimensionaal proces, waarbij inwoners proberen om te gaan met bronnen en voorzieningen, relaties hebben en aangaan, zich geïncludeerd voelen in de (lokale) samenleving en deelnemen aan activiteiten in diezelfde samenleving (Van Houten, 2008; Ogg, 2005; Levitas et al., 2007; The World Bank, 2007). Dit impliceert dat sociale inclusie beschreven kan worden in twee dimensies, te weten activering en internalisatie aan de ene kant en participatie en connectie aan de andere kant (Fortuin and Keune, 1997; Guildford, 2000; Mastergeorge, 2001; Verté et al., 2007). Guildford (2000) geeft aan dat mensen geaccepteerd willen worden door familie, vrienden en de samenleving. Ze proberen zich een plek eigen te maken. Ook wel "internalisatie" genoemd (Mastergeorge, 2001). Welzijnsprojecten tonen echter aan dat de stap naar internalisatie niet altijd gezet kan worden (Fortuin and Keune, 1997). Soms blijft het bij aanleren van vaardigheden en kennis of gedrag dat nog toegepast moet worden. Het blijft dan slechts bij "activering" van volwassenen. Naast het zich eigen maken van een plek in de samenleving, kan ook de stap worden gezet naar actieve deelname (Guildford, 2000). "Participatie" in wijkactiviteiten, activiteiten voor een vereniging of in kunst- en cultuuractiviteiten zijn daarvan voorbeelden. Verté et al. (2007) geeft aan dat participatie niet alleen een individueel proces is, maar dat deelname aan activiteiten juist interactie met mensen bevordert. Volgens Colley (1975), Smith (2007), Huisman et al. (2003) en Priemus (2005) een proces van "connectie".

\section{De rol van de leeromgeving betreffende de bevordering van sociale inclusie}

Leerprogramma's in het volwassenenonderwijs met als doel het bevorderen van sociale inclusie kunnen als effectief worden gezien als deelnemers de aangeleerde kennis, vaardigheden en houding kunnen toepassen in het dagelijks leven, ook wel het transfer-of- 
training effect genoemd. Met name binnen het HRD-onderzoeksdomein (Human Resource Development) is veel onderzoek gedaan naar de effecten van trainingen (een vorm van volwassenonderwijs) (o.a. Holton, Chen en Naquin, 2003; Cheng en Hampson, 2008). In de meeste studies tonen de onderzoeksresultaten aan, dat er zwak tot gematigd transfer of training effect is (Baldwin en Ford, 1988; Nijhuis, Segers en Gijselaers, 2005; Cheng en Hampson, 2008; Holton, Chen en Naquin, 2003; Thijssen, 2001; Nijman, 2004). De meeste HRD-studies refereren naar de opbrengsten van trainingsprogramma's in termen van professionele ontwikkeling gerelateerd aan het functioneren op de werkvloer (o.a. Cheng en Hampson, 2008 en Holton, Chen en Naquin, 2003), terwijl ons onderzoek zich richt op de implementatie van geleerde kennis, vaardigheden en houding in het dagelijks leven. Op basis van eerder transfer of training onderzoek, onderscheiden we drie groepen variabelen waarvan verondersteld kan worden dat ze een invloed hebben op de opbrengsten van volwassenonderwijs, te weten: deelnemerskenmerken, het transfer design en de leefomgeving van de deelnemers.

\subsection{Deelnemerskenmerken}

De mate van sociale inclusie kan allereerst afhankelijk zijn van de achtergrond van kwetsbare volwassenen zelf. Volgens de onderzoeksresultaten van Verté et al. (2011) kunnen deelnemerskenmerken zowel iemands sociale inclusie bevorderen als beperken. De kenmerken die volgens Verté et al. (2011) van invloed kunnen zijn op wel of geen toename van sociale inclusie zijn: geslacht, etnische afkomst, leeftijd, aantal kinderen, burgerlijke staat, onderwijsniveau, aantal opleidingsjaren, het hebben van wel of geen (vrijwilligers)baan, het hebben van wel of geen diploma's, motivatie tot deelname en de eerder gevolgde cursussen. Ten tweede kan de mate van zelfsturing van invloed zijn op het leerproces en de leeropbrengsten van de deelnemers (McGivney, 1992; Raemdonck, 2006). Zowel Knowles (1975) als Mezirow (1997) onderschrijven het belang van zelfsturing tijdens het leerproces. Volgens Raemdonck (2006) is zelfsturing tijdens het leren een proces, waarbij de deelnemer zijn of haar eigen leerproces kan beïnvloeden om op de gewenste manier in de eigen situatie te kunnen functioneren. Haar onderzoek toont aan dat met name het leerproces van laagopgeleide deelnemers beïnvloed wordt door hun mate van zelfsturing. Ten derde kan motivatie een bepalende factor zijn voor leersucces. Volgens Baldwin en Ford (1988) en Holton, Chen and Naquin (2003) is de deelnemer een onafhankelijk individu met een eigen motivatie tijdens het leren. Eveneens geven Pugh and Bergin (2006) aan dat motivatie de mate van transfer kan beïnvloeden. 


\subsection{Transfer design: transferklimaat, leerinhoud en -activiteiten en docentondersteuning}

Verschillende elementen van de leeromgeving zijn in eerder transfer of training onderzoek aangetoond als van invloed op transfer effecten (bijv. Nijman, 2004): het transferklimaat, de leerinhoud en -activiteiten en de ondersteuning door de docent.

Het transferklimaat refereert ten eerste naar de verschillende omgevingsfactoren van de deelnemer, die ervoor zorgen dat de geleerde kennis, vaardigheden en houding wordt toegepast of eigen gemaakt in het dagelijks leven (Burke en Baldwin, 1999). In onze studie betreft het hier de transfermogelijkheden en de directe omgeving. De directe omgeving bij de studie van Nijman (2004) betreft de werkomgeving, terwijl ons onderzoek zich focust op de dagelijkse leefomgeving die transfer kan blokkeren of stimuleren.

Ten tweede is volgens vele auteurs de leerinhoud en soort leeractiviteiten van belang voor de leerimpact. Een aantal auteurs onderstrepen dit belang vanuit een constructivistisch leerperspectief, dat volgens Tenenbaum et al. (2001) uit de volgende principes bestaat: (1) het gebruik van argumenten, discussies en debatten onder deelnemers, (2) het toepassen en ontwikkelen van conceptuele conflicten en dilemma's, (3) het delen van elkaars ideeën, (4) het gebruik van oplossingsgerichte materialen en maatregelen, (5) het bevorderen van de mate van reflectie en onderzoek onder deelnemers, (6) de afstemming op deelnemersbehoeften en (7) betekenisgeving aan voorbeelden uit het dagelijks leven tijdens lesinstructies.

Ten slotte speelt volgens Pratt (1998) de docent een belangrijke rol in de volwasseneneducatie en moet deze een ondersteunende coach zijn, die deelnemers stimuleert in het toepassen van de geleerde competenties en hen leert omgaan met mogelijke weerstand uit de dagelijkse omgeving. De rol van de docent kan die van trainer (Simons en Bolhuis, 2004), consultant (Van Lakerveld et al., 2000), supervisor (Holton, Chen en Naquin, 2003) of van "gids" (Van der Vlerk, 2005) zijn om sociale inclusie te bevorderen.

\subsection{Deelnemersomgeving}

Eerdere studies naar transfer of training wijzen op de rol van de werkomgeving in het bevorderen van transfer. In onze studies, waar we onze richten onderwijsprogramma's die het bevorderen van sociale inclusie beogen, ligt de focus niet op de werkomgeving, maar op het dagelijks leven van de deelnemer. Volgens Liu (1974) en Andrews en Withey (1974) is de leefomgeving, meer bepaald de levensomstandigheden van de deelnemer van belang. Voorbeelden zijn het familieleven naast het wel of niet functioneren in een betaalde baan, het opvoeden van kinderen en de mogelijke zorg voor anderen (Andrews en Withey, 1974). Naast deze blokkerende of stimulerende levensomstandigheden voor sociale inclusie zijn er volgens McGivney (1992) diverse barrières, zoals zich te oud voelen om te leren en mobiliteitsproblemen, die transfer (en dus de toename van sociale inclusie) verhinderen. 


\section{Onderzoeksvragen betreffende de outcome van onderwijsprogramma's ter bevordering van sociale inclusie}

Aangezien tot op heden weinig inzicht is in de opbrengsten van programma's van volwasseneneducatie, zijn vooralsnog vijf onderzoeksvragen onbeantwoord. Deze onderzoeksvragen zijn richtinggevend voor deze studie en trachten inzage te verschaffen in de opbrengsten van volwasseneneducatie in termen van sociale inclusie voor verschillende subgroepen van deelnemers en in de mogelijk beïnvloedende kenmerken van de leeromgeving. De vijf onderzoeksvragen zijn:

Onderzoeksvraag 1: "Wat zijn de kwalitatief verschillende percepties van deelnemers in het ervaren van toename van sociale inclusie na deelname aan programma's binnen het volwassenenonderwijs?"

Onderzoeksvraag 2: "Wat zijn de kritische succesfactoren van de leeromgeving, die de verschillende percepties van toename van sociale inclusie beïnvloeden?"

Onderzoeksvraag 3: "Welke specifieke opbrengsten in termen van sociale inclusie ervaren deelnemers na deelname aan programma's binnen het volwassenenonderwijs?"

Onderzoeksvraag 4: "Wat zijn de verschillen tussen subgroepen van deelnemers met het oog op toename van sociale inclusie (in termen van activering, internalisatie, participatie en connectie) na deelname aan een programma van het volwassenenonderwijs?"

Onderzoeksvraag 5: "Wat is de relatie tussen de leeromgeving en de toename op sociale inclusie na deelname aan programma's binnen het volwassenenonderwijs?"

\section{Setting}

De onderzoeksdoelgroep bestond uit voornamelijk laagopgeleide deelnemers, die deelnamen aan trajecten volwassenenonderwijs binnen Regionale Opleidingen Centra (ROC's) in Nederland. Om antwoord te krijgen op de eerste onderzoeksvraag zijn in twee ROC's 32 deelnemers geworven, die een cursus betreffende basisvaardigheden of lees- en schrijfvaardigheden volgden. Voor onderzoeksvraag 2 en 3 hebben 787 deelnemers, die deel namen aan een cursus betreffende basisvaardigheden, lees- en schrijfvaardigheden of digitale vaardigheden in 31 verschillende ROC's (met 39 locaties) aan het begin van de betreffende cursus en 515 deelnemers aan het eind van diezelfde cursus een vragenlijst ingevuld. 


\section{Resultaten}

\subsection{Onderzoeksvragen 1 en 2}

Op basis van het fenomenografisch onderzoek werd duidelijk dat deelnemers vier concepties van sociale inclusie ervaren, te weten: activering, internalisatie, participatie en connectie. Uit de onderzoeksresultaten blijkt, dat de meeste deelnemers zichzelf beter weten te redden (activering) en daarnaast het gevoel hebben een sterkere identiteit te zijn (internalisatie). Daarentegen ervaart een kleiner deel, dat ze meer ruimte hebben gekregen om nieuwe dingen te doen in de samenleving (participatie) en nieuwe relaties aangaan of bestaande relaties verbeteren (connectie). Met andere woorden hebben meer deelnemers vooruitgang ervaren op de individueel gerichte componenten van sociale inclusie dan de componenten, waarbij de omgeving ook een rol speelt. Daarnaast indiceren de resultaten dat bij een groot aantal deelnemers docentondersteuning wordt gezien als van invloed is op de toename van sociale inclusie, doordat deze hen aanmoedigt tot leren of hen stimuleert tot transfer. Wat minder deelnemers geeft aan dat de leerinhoud en -activiteiten (gebaseerd op het constructivistisch perspectief) van invloed is op hun toename van sociale inclusie, evenals de invloed van hun levensomstandigheden en hun leefomgeving, die hen ondersteunt om zelfredzamer te worden in het dagelijks leven, hen bewust maakt van de gemaakt progressie door leren en ervoor zorgt dat ze dingen op eigen initiatief gaan doen. Ten slotte wordt duidelijk dat zelfsturing door de minste deelnemers is aangegeven als van invloed op de vooruitgang in sociale inclusie. Deze zelfsturing is soms gebaseerd op een intrinsieke dan wel een extrinsieke motivatie en bereidheid tot leren.

\subsection{Onderzoeksvragen 3 en 4}

Volgende stap is om aan te tonen onder welk deel van de deelnemers een toename van sociale inclusie is te constateren na deelname aan een traject volwasseneneducatie. De toename van sociale inclusie op de verschillende variabelen van sociale inclusie varieert van $21.8 \%$ ("lidmaatschap") tot $54.7 \%$ ("digitale vaardigheden"). Bij 5 variabelen ervaart $40 \%$ of meer van de deelnemers een toename van sociale inclusie, te weten: "digitale vaardigheden", "internationale taalvaardigheden", "assertiviteit", "sociaal isolement" en "verenigings- en wijkactiviteiten". Daarnaast ervaart een groter aantal deelnemers meer toename op de schaal van "activering en internalisatie" (46.3\%) dan op de schaal van "participatie en connectie" (41\%).

Uit de bivariate analyses wordt vervolgens duidelijk dat met name samenwonende en allochtone deelnemers i.p.v. getrouwde, ongetrouwde, autochtone deelnemers of weduwen en weduwnaars meer vooruitgang boeken op 3 of meer specifieke variabelen van sociale inclusie. Zo vertonen samenwonenden meer vooruitgang dan getrouwden, ongetrouwden en weduwen en weduwnaars op het gebied van "nationale taalvaardigheden", "digitale vaardigheden", "assertiviteit", "arbeids- en opvoedingsvaardigheden", 
"contactvaardigheden", "ontmoeten en ondernemen", "intieme contacten" en op de schaal van "activering en internalisatie". Allochtone deelnemers ervaren daarnaast meer toename dan autochtone deelnemers op het gebied van "nationale taalvaardigheden", "ontmoeten en ondernemen" en "intieme contacten", terwijl autochtone deelnemers juist meer toename op het gebied van "kunst- en cultuuractiviteiten" ervaren. Enkele andere opvallende zaken zijn dat mannen meer toename dan vrouwen ervaren op het gebied van "assertiviteit" en dat ouderen meer dan jongeren een toename op het gebied van "digitale vaardigheden" ervaren. Ten slotte ervaren deelnemers met minder kinderen meer toename op het gebied van "assertiviteit" en "sociaal isolement" en ervaren lageropgeleiden meer toename op het gebied van "internationale taalvaardigheden" en "intieme contacten".

\subsection{Onderzoeksvraag 5}

Om inzage te verkrijgen in welke kenmerken van de leeromgeving de toename van sociale inclusie beïnvloeden is een logistische regressieanalyse uitgevoerd. De onderzoeksresultaten tonen aan dat met name de variabele transfermogelijkheden een grote invloed heeft op de meeste variabelen van sociale inclusie, te weten: "digitale vaardigheden", "assertiviteit", "arbeids- en opvoedingsvaardigheden", "vrijwilligerswerk- en wijkvaardigheden", "verenigings- en wijkactiviteiten", "kunst- en cultuuractiviteiten" en "lidmaatschap". Daarnaast hebben "barrières" (zoals mobiliteitsproblemen of zich te oud voelen om te leren) invloed op "internationale taalvaardigheden", het verlenen van "zorg" op "verenigings- en wijkactiviteiten", het verzorgen van een "opvoeding" en het hebben van "werk" op "arbeidsen opvoedingsvaardigheden" en "vrijwilligerswerk- en wijkvaardigheden" en "leerinhoud en activiteiten" op "contactvaardigheden" .

\section{Implicaties voor de praktijk: "Transitie naar sociale inclusie door levenslang leren"}

Uit de resultaten van ons onderzoek wordt duidelijk dat deelname aan programma's van volwasseneneducatie kan leiden tot een toename in sociale inclusie, oftewel een betere plek in de samenleving, met name op 4 gebieden, te weten: activering, internalisatie, participatie en connectie. Op de schaal van "activering en internalisatie" vertoont $46.3 \%$ van de deelnemers een toename van sociale inclusie, terwijl dat op de schaal van "participatie en connectie $41 \%$ is. Kijkend naar de deelnemers zelf is vooral vooruitgang te constateren voor samenwonenden op een aantal gebieden, te weten: "nationale taalvaardigheden", "digitale vaardigheden", "assertiviteit", "arbeids- en opvoedingsvaardigheden", "contactvaardigheden", "ontmoeten en ondernemen", "intieme contacten" en op de schaal van "activering en internalisatie". Daarnaast wordt duidelijk dat allochtone deelnemers meer toename dan autochtone deelnemers ervaren op het gebied van "nationale 
taalvaardigheden", "ontmoeten en ondernemen" en "intieme contacten", terwijl autochtone deelnemers juist meer toename op het gebied van "kunst- en cultuuractiviteiten" ervaren. Leeftijd, geslacht en opleidingsniveau blijken voor een enkele variabele van sociale inclusie een rol te spelen, maar deze is veel geringer dan etnische afkomst en burgerlijke staat. De bepalende rol van deze sociodemografische kenmerken impliceert, dat programma's van levenslang leren binnen de volwasseneneducatie gedifferentieerde programma's moeten zijn, die aansluiten bij verschillende leerbehoeften van verschillende groepen deelnemers. Dit zal de kwaliteit van de programma's ten goede komen.

Volgens het UNESCO Institute for Lifelong Learning (2009) was ook één van de belangrijkste conclusies van de CONFINTEA VI Conferentie dat inzage in de meest belangrijke kenmerken van volwasseneneducatie van belang zijn om haar kwaliteit te waarborgen. Kijkend naar onze onderzoeksresultaten blijkt dat allereerst transfermogelijkheden de bepalende factor is voor de meeste variabelen van sociale inclusie. Oftewel de mogelijkheden om de geleerde kennis, vaardigheden en houding toe te passen in het dagelijks leven heeft de meeste invloed op het bereiken van een betere plek in de samenleving na deelname aan een programma van volwasseneneducatie. Daarnaast spelen leerinhoud en -activiteiten en barrières, opvoeding en werk en ten slotte het verlenen van zorg aan een ander een mindere, maar wel belangrijke rol in het behalen van het leersucces.

Met het oog op deze onderzoeksresultaten zouden de professionals en managers in de praktijk van volwasseneneducatie een antwoord moeten geven op vier nieuwe eisen voor programma's van volwasseneneducatie.

Allereerst om de transfermogelijkheden te vergroten zou gezocht moeten worden naar een combinatie van non-formeel en formeel leren. Naast het leerproces in de klassikale setting, moeten er ook voldoende praktijkmomenten zijn, zoals het voeren van gesprekken op het werk of de deelname aan activiteiten in de wijk, waarbij deelnemers het geleerde kunnen toepassen.

Ten tweede zouden er voldoende voorbeelden uit het dagelijks leven gebruikt moeten worden tijdens het leerproces. Met name voor kwetsbare volwassenen is het zaak, dat zij zich in de materie herkennen en de mogelijkheden zien om op basis van reflectie hun houding in de praktijk te optimaliseren. Hierdoor zal hun contact met hun dagelijkse leefomgeving verbeterd kunnen worden, doordat ze het voorbeeld uit de leersetting direct kunnen toepassen.

Ten derde doet het ook een ander appèl op de ondersteuning van de docent. Hij of zij zal eerder een faciliterende functie krijgen, waarbij hij of zij een veilige leeromgeving weet te creëren. In deze leeromgeving krijgen deelnemers de kans om middels reflectie hun "fouten" te (h)erkennen en vervolgens de juiste aanpak voor het dagelijks leven onder de knie te krijgen. De docent zal hen dan kunnen ondersteunen bij de implementatie van de aangeleerde "aanpak".

Ten slotte zal de opbouw van een educatief programma er anders uit komen te zien. Er moeten meer mogelijkheden tot transfer zijn, waarbij momenten van coaching in de praktijk 
langer worden en meer aandacht krijgen. Dit om te voorkomen dat er te weinig aandacht is voor de leerbehoeften van de deelnemers en daarnaast de transfer van de geleerde kennis, vaardigheden en houding is vastgelegd.

\section{Suggesties voor vervolgonderzoek}

Deze studie moet echter gezien worden als een eerste aanzet om inzage te krijgen in de outcome van volwasseneneducatie in termen van sociale inclusie en te achterhalen wat de meest bepalende factoren voor dit leersucces kunnen zijn.

Deze onderzoeksresultaten zijn allereerst gebaseerd op de Nederlandse setting. Een mogelijkheid zou kunnen zijn om een vervolgonderzoek te realiseren in verschillende landen, waardoor culturele verschillen en invloeden bij leerprocessen in beeld gebracht kunnen worden.

Ten tweede zijn de onderzoeksresultaten verkregen op basis van "self-reports" onder de deelnemers. Hierdoor werd duidelijk wat de ervaren mate van toename van sociale inclusie onder de deelnemers was. Het verdient aanbeveling om dit ook in beeld te brengen via andere maten, waardoor mogelijke "overschatting" van de deelnemers voorkomen kan worden.

Ten slotte stap zou een cross-validatie van het huidige onderzoeksmodel kunnen zijn. Volgens Cascallar en Musso (2008) zou de methode van "Neural Network Analysis" een manier kunnen zijn om het onderzoeksmodel uit te breiden en haar predictieve kracht te kunnen versterken. Soortgelijk toekomstig onderzoek kan ervoor zorgen, dat er nog scherper inzicht wordt verkregen in succesfactoren voor volwasseneneducatie met als doel het vergroten van sociale inclusie. Dit onderzoek is in ieder geval een eerste aanzet geweest om effecten van programma's van levenslang leren uit het volwassenenonderwijs in kaart te brengen, waarbij duidelijk werd dat de leeromgeving in ieder geval voor een aantal kwetsbare volwassenen voor een betere plek in de samenleving kan zorgen.

\section{Referenties}

Andrews, F. M. \& Withey, S. B. (1974). Developing measures of perceived life quality: Results from several national surveys. Social Indicators Research, 1974 (1), 26.

Baldwin, T. T. \& Ford, K. J. (1988). Transfer of training: A review and directions for future research. Personnel Psychology, 1988 (41), 43.

Bijl, R., Boelhouwer, J., Cloin, M. \& Pommer, E. (2011). De sociale staat van Nederland 2011. Den Haag: Sociaal Cultureel Planbureau.

Burke, L.A., \& Baldwin, T.T. (1999). Workforce training transfer: A study of the effect of relapse prevention training and transfer climate. Human Resource Management, 38 (3), 227 - 242. 
Bynner, J. \& Londra, M. (2004). The impact of government policy on social exclusion among young people. London: The Office of the Deputy Prime Minister.

Cascallar, E. C. \& Musso, M. (2008). Classificatory Stream Analysis in the Prediction of Expected Reading Readiness: Understanding Student Performance. International Journal of Psychology, XXIX International Congress of Psychology ICP 2008, 43, (3/4): 231.

Cheng, E. W. L. \& Hampson, I. (2008). Transfer of training: A review and new insights. International Journal of Management Reviews 10 (4), 15.

Christian, D. E. (1974). International Social Indicators: The OECD Experience. Social Indicators Research 1 (2), 169.

Colley, D. G. (1975). A social change index - an objective means to discern and measure the relative current social condition of cities, towns, and their sub-communities. Social Indicators Research, 1975 (1), 26 .

Dahlstedt, I. \& Bevelander, P. (2010). General versus vocational education and employment integration of immigrants in Sweden. Journal of Immigrant and Refugee Studies, 8 (2), 158 - 193.

Dannefer, D. (2003). Cumulative Advantage / Disadvantage and the Life Course: Cross-Fertilizing Age and Social Science Theory. Journal of Gerontology: Social Sciences 58B (6), 327 - 337.

De Greef, M., Segers, M. \& Verté, D. (2010). Development of the SIT, an instrument to evaluate the transfer effects of adult education programs for social inclusion. Studies in Educational Evaluation (36), 42 - 61.

De la Fuente Anuncibay, R. (2007). Social, personal and educational constraints on access to employment among groups at risk of social exclusion: contributions from an employment observatory. Journal of Vocational Education and Training, 59 (4), 435 - 449.

EARLALL - European Association of Regional and Local Authorities for Lifelong Learning. (2011). Policypaper: Decreasing the number of low-skilled people. Bruxelles: EARLALL.

Endler, N., S. \& Magnusson, D. (1976). Toward an interactional psychology of personality. Psychological Bulletin, 83, 956 - 974.

European Commission. (2010). Communication from the commission to the European Parliament, the Council, the European Economic and Social Committee and the Committee of the Regions: The European Platform against Poverty and Social Exclusion: A European framework for social and territorial cohesion. Brussels: European Commission.

Eurostat (2010). Combating poverty and social exclusion. Luxembourg: European Union.

Eurostat (2012). Euro area unemployment rate at 10.3\%. Luxembourg: Eurostat.

Fortuin, K. and Keune, C. (1997). Anders praten over jeugd: Naar een begrippenkader voor preventief jeugdbeleid. Utrecht: Verwey-Jonker Instituut.

Guildford, J. (2000). Making the case for social and economic inclusion. Canada Atlantic Region: Population and Public Health Branch.

Holton, E. F., Chen H. \& Naquin, S. S. (2003). An examination of learning transfer system characteristics across organizational settings. Human Resource Development Quarterly, vol. 14 (4), 24.

Huisman, J., Pijls, T., Van Hoeij, J., Van Voorst van Beest, K., Boonaerts, Y. \& Lens, M. (2003). Portfolio sociale competenties: Primair onderwijs, vmbo, mbo. 's-Hertogenbosch: CINOP. 
Knowles, M. S. (1975). Self-directed learning: A guide for learners and teachers. New York: Association Press.

Krueger, R. F., South, S., Johnson, W. Iacono, W. (2008). The heritability of personality is not always 50\%: Gene-environment interactions and correlations between personality and parenting. Journal of Personality, 76, 1485 - 1522.

Levitas, R., Pantazis, C., Fahmy, E., Gordon, D., Lloyd, E. \& Patsios, D. (2007). The Multidimensional analysis of social exclusion. London: Department for Communities and Local Government.

Liu, B. (1974). Quality of life indicators: a preliminary investigation. Social Indicators Research, 1974 (1), 22, 187 - 208.

Marton, F. \& Booth, S. (1997) Learning and awareness. Mahwah, N. J.: Lawrence Erlbaum.

Mastergeorge, A. M. (2001). Guided Participation in sociocultural learning: Intervention and apprenticeship. Academic Search Premier, 22 (1), 14.

McGivney, V. (1992). Tracking adult learning routes: A pilot investigation into adult learners'starting points and progression to further education and training. Leicester: National Institute of Adult Continuing Education.

Mezirow, J. (1997). Transformative Learning: Theory to Practice. In: Transformative learning in action: insights from practice. New directions for adult and continuing education, 74, 5 - 12.

Nijhuis, J. F. H., Segers, M. S. R. \& Gijselaers, W. H. (2005). Influence of redesigning a learning environment on student perceptions and learning strategies. Learning Environments Research, 2005 (8), 27.

Nijman, D.J.J.M. (2004). Supporting Transfer of Training: Effects of the Supervisor. Enschede: Universiteit Twente.

Nilsson, A. (2010). Vocational education and training - an engine for economic growth and a vehicle for social inclusion. International Journal of Training and Development, 14, 4, 251 - 272.

Nye M. \& Hargreaves, T. (2009). Exploring the Social Dynamics of Proenvironmental Behavior Change: A Comparative Study of Intervention Processes at Home and Work. Journal of Industrial Ecology, vol. $14(1), 137$.

Ogg, J. (2005). Social exclusion and insecurity among older Europeans: the influence of welfare regimes. Ageing \& Society, 25, 69.

Pratt, D. D. (1998). Five perspectives on teaching in adult and higher education. Malabar, Florida: Krieger Publishing Company.

Priemus, H. (2005). Het spel en de knikkers: Fysieke en sociale pijler verbonden. Tijdschrift B\&G / Uitgave Bank Nederlandse Gemeenten en Vereniging van Nederlandse Gemeenten, 2005 (1), 5.

Pugh, K. J., \& Bergin, D. A. (2006). Motivational Influences on Transfer. Educational Psychologist, 41 (3), $147-160$.

Raemdonck, I. (2006). Self-directedness in learning and career processes: A study in lower-qualified employees in Flanders. Gent: Universiteit van Gent.

Simons, R-J. S. \& Bolhuis, S. (2004). Constructivist learning theories and complex learning environments. In Mulder, R.H. \& Sloane, P.F.E., New approaches to vocational education in Europe. The construction of complex learning-teaching arrangements. Oxford: Symposium Books; and in Oxford Studies in Comparative Education, 13 (1), 13 - 25. 
Smith, M. K. (2007). Social capital. The encyclopedia of informal education, 2007. 26 - 07 - 2007. $<$ www.infed.org/biblio/social_capital.htm>.

Tenenbaum, G., Naidu, S., Jegede, O. \& Austin, J. (2001). Constructivist pedagogy in conventional on campus and distance learning practice: An exploratory investigation. Learning and construction 11, 25.

The World Bank. (2007). Social Exclusion and the EU's Social Inclusion Agenda: Paper Prepared for the EU8 Social Inclusion Study. Washington: The World Bank.

Thijssen, J. (2001). Personele flexibiliteit in strategisch perspectief: De betekenis van employability voor organisatie en individu. In R. Poell \& J. Kessels, Human Resource Development, Organiseren van het leren. Alphen aan den Rijn: Samsom, 103 - 116.

Tsakloglou, P. \& Papadopoulos, F. (2002). Aggregate level and determining factors of social exclusion in twelve European countries. Journal of European Social Policy 12 (3), 211 - 225.

UNESCO Institute for Lifelong Learning - UIL. (2009) Global Report on Adult Learning and Education: Executive Summary. Hamburg: UNESCO Institute for Lifelong Learning - UIL.

UNICEF. (2008). The state of the world's children. New York: UNICEF.

Van Houten, D. (2008). Werken aan inclusie. Tijdschrift Sociale Interventie, 17 (3), 45 - 56.

Van der Vlerk, D. (2005). Inspireren tot leren: Het ontwerpen van een uitdagende leeromgeving. Bussum: Uitgeverij Coutinho.

Van Lakerveld, J., Van den Berg, J., De Brabander, C., \& Kessels, J. (2000). The corporate curriculum: a working-learning environment. In Proc. Annual Academy of Human Resource Development Conference: Expanding the Horizons of Human Resource Development. Raleigh-Durham NC.

Verté, D., De Witte, N. \& De Donder, L. (2007). Schaakmat of aan zet? Monitor voor lokaal ouderenbeleid in Vlaanderen. Brugge: Uitgeverij Van den Broele.

Verté, D., Dury, S., De Donder, L., Buffel, T. \& De Witte, N. (2011). Doe mee! Over ouderen en maatschappelijke participatie. Brugge: Provinciebestuur van West-Vlaanderen. 